Historic, archived document

Do not assume content reflects current scientific knowledge, policies, or practices. 

Northeastern Forest

Experiment Station

Resource Bulletin NE-137

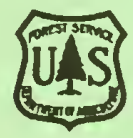

Thomas W. Birch

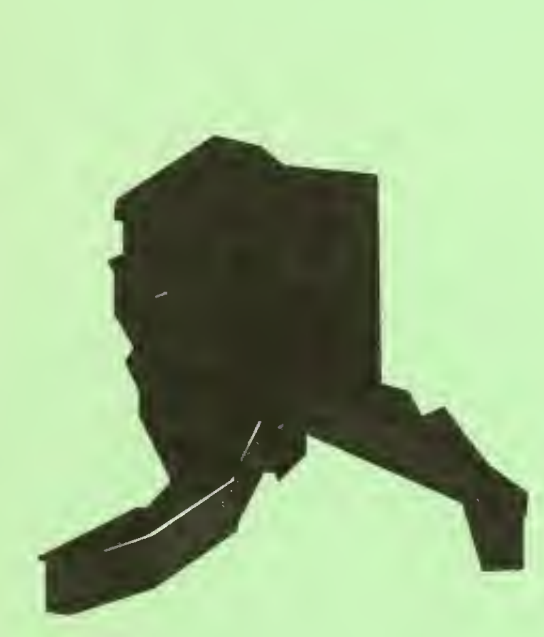

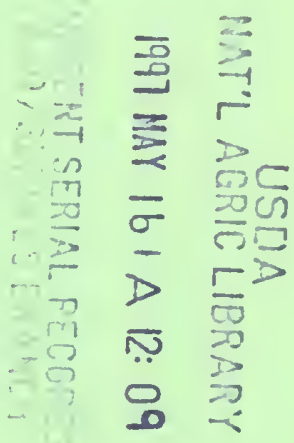

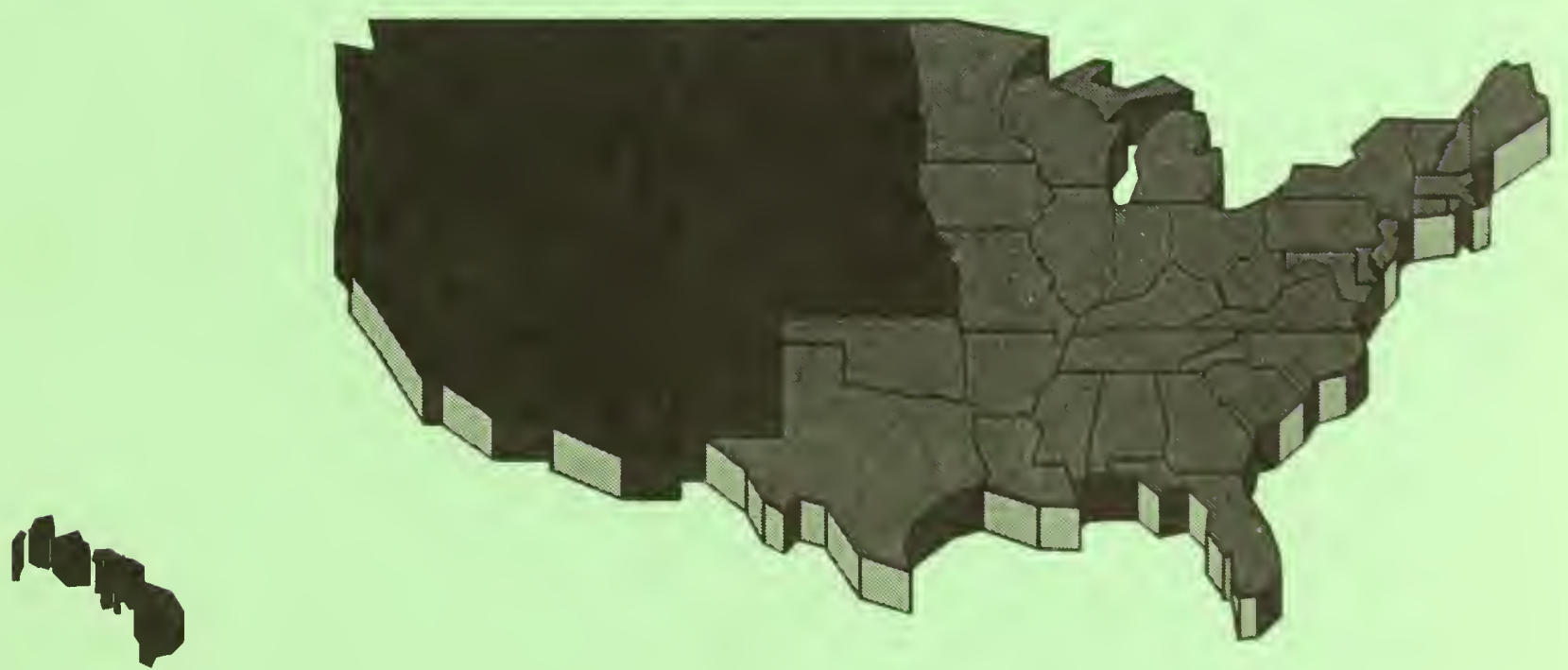


Information from a recent study of forest-land owners has provided a new estimate of the number of ownerships and insight into the attitudes and actions of this important group of decision makers. Nearly 71 percent the private forestland is in ownerships of more than 500 acres. An estimated 43 percent of these owners have harvested timber from their holdings at some time in the past. Owners have a positive attitude toward timber cutting at a time when there is greater demand for products from the forest. Interest in harvesting the timber resource has created a situation in which watchful monitoring and good stewardship are needed to maintain the productivity of ecosystems for future generations.

\section{The Author}

THOMAS W. BIRCH, forester, received B.S. and M.S. degrees from Michigan State University in 1969 and 1974, respectively. He joined the USDA Forest Service's Northeastern Forest Experiment Station in 1974 and currently is with the Station's Forest Inventory and Analysis unit in Radnor, Pennsylvania.

\section{Acknowledgments}

This report has been a team effort, involving the work and contributions of many people. Foremost among these were the efforts of the private forest-land owners who took the time to complete and return a questionnaire.

The help of the Forest Inventory and Analysis Research Work units at the USDA Forest Service Experiment Stations is greatly appreciated. Vickie Sharon was responsible for administrative and secretarial services. Significant contributions also were made by Cecile Stelter, Beverly Grant, Anne Cane, Ray Sheffield, Gerald Craver, Patrick Miller, Jack London, Joanne Faulkner, Earl Leatherberry, Gem Blair, Dwane VanHooser, and Willem van Hees. Members of the Coordination Committee for this study included Fred Kaiser, Chair (Forest Service); Terri Bates, (National Association of State Foresters); Bob Smith and Jeff Goebel (National Resources Conservation Service); and Robert Moulton and Jim Bones (Forest Service). The efforts of the Statistical Laboratory at lowa State University and Sarah Nusser in choosing the sample locations drawn for most states ensured well-distributed coverage. I also thank all those who gathered names and addresses, and contacted owners who had not responded to the questionnaire through the mail, particularly state service foresters and forest inventory staffs.

Manuscript received for publication 30 September 1996.

Published by:

USDA FOREST SERVICE

5 RADNOR CORP CTR SUITE 200

RADNOR PA $19087-4585$
For additional copies:

USDA Forest Service Publications Distribution 359 Main Road

Delaware, $\mathrm{OH} 43015$ 


\title{
Private Forest-land Owners of the Western United States, 1994
}

\author{
Thomas W. Birch
}

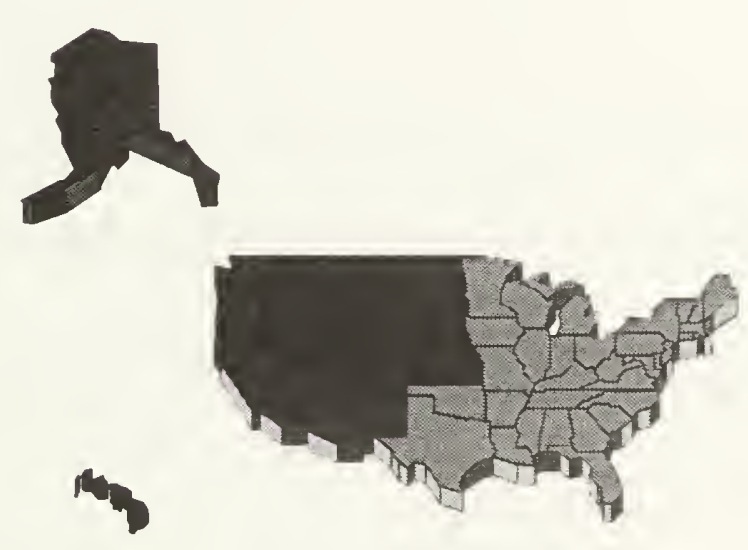

Contents

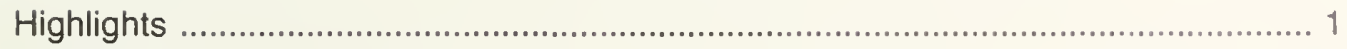

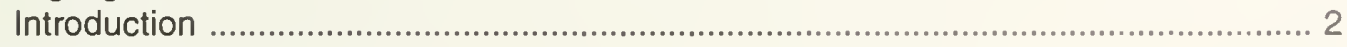

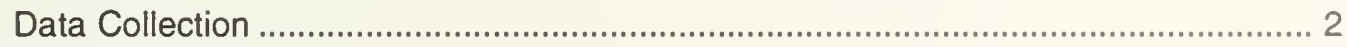

Private Forest Owners .................................................................................. 2

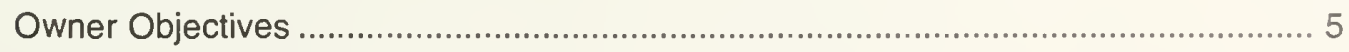

Timber Harvesting Behavior ......................................................................... 7

Management Planning .............................................................................. 7

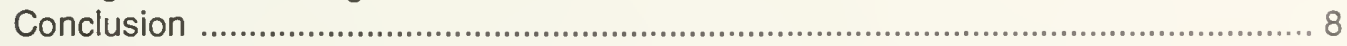

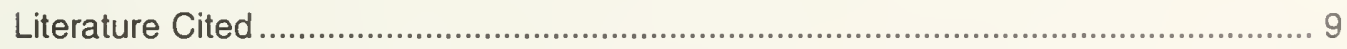

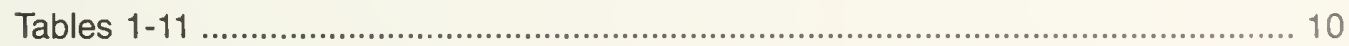

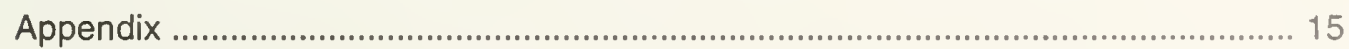

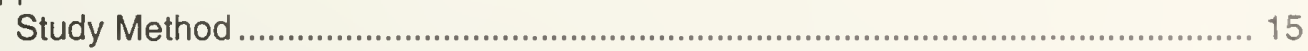

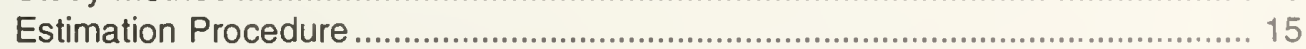

Data Accuracy and Reliability ........................................................... 16

Definition of Terms .............................................................................. 17

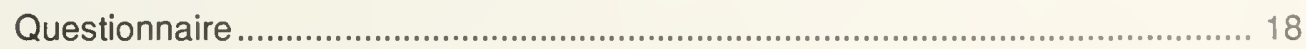

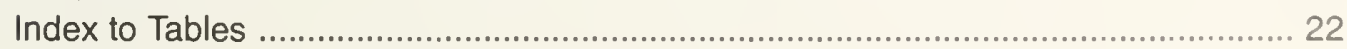





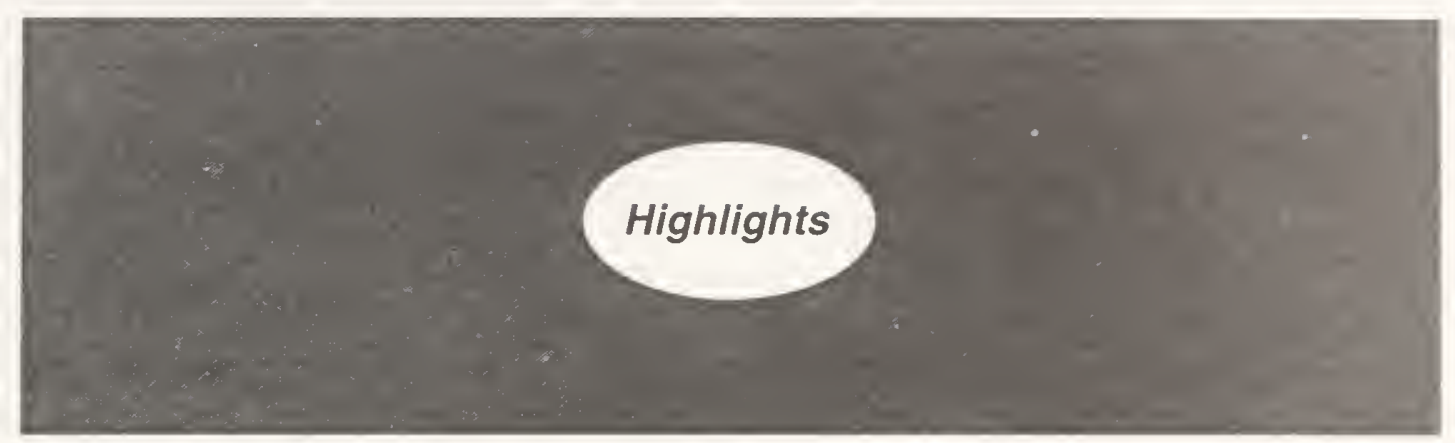

* An estimated 1.03 million private ownerships control more than 76 million acres of forest land in the Western United States.

Nearly 71 percent of the private forest is in ownerships of more than 500 acres.

- Corporations, partnerships, clubs, and other ownerships with multiple owners hold 67 percent of the acreage, while "retired" owners control one-third of the remaining 33 percent.

$\because$ Forty-nine percent of the ownerships first acquired forest land since 1978; these owners control 22 percent of the private forest.

$\therefore \quad$ Seven percent of the private forest-land owners have a written management plan; they control 53 percent of the private forest. 


\section{Introduction}

Our forest resources are vital to the social and economic well-being of our society. Good management of the forest requires a thorough knowledge of the resource base and the factors affecting it. Forest owners are the essential connecting link between the general public and the land. This publication reports on the Western United States from a 1994 study of forest-land owners nationwide (Birch 1996), and includes estimates of the number of private forest-land ownerships. Also described are ownership objectives, expected benefits, harvest experience, intention to harvest, and management planning. The first nationwide ownership study for the United States was conducted in 1978 (Birch and others 1982). This report also reviews trends that have occurred between the 1978 and 1994 national surveys.

In this report, an ownership unit refers to persons, combinations of persons or legal entities such as corporations, partnerships, clubs, trusts, Indian Tribes, and Native corporations. One person may own several parcels or partial interest in several parcels. An ownership unit controls a parcel or group of parcels of land. Our sample is drawn from the land itself (parcel by parcel), and the owner of record (the apparent owner) is determined. Finally, an individual who has some control of an amount of land (not exclusively the parcel sampled) responds to the survey. Therefore, ownership units and not owners are being sampled.

Landowners have rights and responsibilities regarding their land. These include the right to purchase additional land or sell existing holdings, determine land use, and choose the type and level of investment. Each of these rights all function within the limits allowed and imposed by society. Ownership of land fixes responsibility for decision making, establishes a claim on income accruing to land, and determines how wealth in land is distributed (Lewis 1980; Boxley 1977; Wunderlich 1978).

\section{Data Collection}

The USDA Forest Service's estimate of 736.7 million acres of forest nationwide, essentially unchanged from 1977 , represents 33 percent of the total land area (Powell and others 1993). Of this, private "forest-land" owners (this and other terms are defined in the Appendix) hold 423.8 million acres (58 percent). Two-thirds of the Nation's forests are classified as timberland (490 million acres). Of this, 358 million acres are in private ownership. This study is based on an estimate of 393 million acres of private forest land, which includes essentially all of the private timberland plus samples of "other forest" in Texas, Oklahoma, Oregon, and California. In addition, data obtained for Indian lands in Arizona, Colorado, Nevada, New Mexico, and Utah included "other forest-land" area. Alaska has 6.2 million acres of private timberland that was covered by Forest Inventory and Analysis (FIA) sample locations. The remaining 23.6 million acres of Alaska's private forest did not have ground samples directly associated by ownership; it is owned primarily by the same Native corporations that hold most of the state's private timberland. For estimation purposes, this report uses 9.9 million acres of private forest in Alaska on the basis of responses from Alaska owners.

In 1977, for comparison, 736.6 million acres of the United States were in forest; of this, 347 million acres were classified as privately owned timberland (USDA For. Serv. 1982). The 1978 study of private forest-land owners of the United States used an estimate of 333 million acres developed by USDA Economic Research Service, Natural Resource Economics Division from the National Resources Inventory (NRI) of the USDA Soil Conservation Service. The difference of 14 million acres (4 percent) was attributed to differences in definitions (Birch and others 1982). It was felt that the proportions from the 1978 study could be applied to the timberland base for resource planning purposes. The principal limitation of the 1978 survey was that it did not include a sufficient number of observations, especially for the Great Plains and Rocky Mountain States, to provide reliable state-level results. Also, there were no observations for Alaska. The 1978 study also did not consider the motivations or management intentions of forest-land owners, for example, their attitudes toward harvesting timber.

The other national estimate of forest-land owners is from the Timber Resource Review of 1953 (USDA For. Serv. 1958). The 1953 data did not include estimates of owners with fewer than 3 acres in the East or fewer than 10 acres in the West. Therefore, direct comparison of numbers of owners should not be made. The comparison by broad size classes could be of some use if coupled with trend data by ownership group (Wall 1981).

The 1978 data were gathered from 11,076 sample locations by the USDA Economic Research Service. The 1994 study was conducted by the Forest Inventory and Analysis projects of the USDA Forest Service in cooperation with the National Association of State Foresters and the USDA Natural Resources Conservation Service, in support of the Forest Stewardship Program of the USDA Forest Service, State and Private Forestry. Questionnaires for the 1994 study were mailed to 23,334 owners of 28,194 privately owned forested sample plots. Sample plot locations were from NRI or FIA plots. Specifics as to which plots were used where are included in the Appendix. Responses from 11,745 ownerships that control 15,700 of these sample plots are included in this report, as are responses from 1,417 ownerships that control 2,584 sample locations in the West. The procedure for estimating the number of private forest-land owners by state and the questionnaire used for this report are included in the Appendix.

\section{Private Forest Owners}

An estimated 9.9 million private forest-land ownership units hold 393 million acres of forest land in the United States. In the 17 Western states there are an estimated 1,030,000 private forest owners with 76.2 million acres of forest land. These owners are diverse in legal organization, economic circumstances, personal characteristics, ownership objectives, and management experience. 


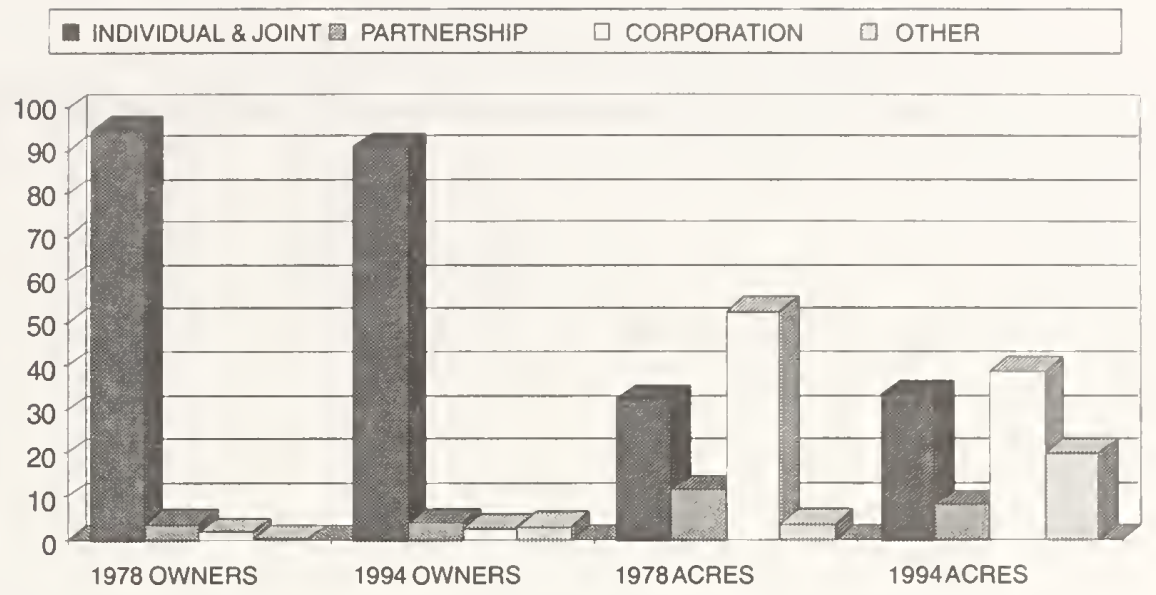

Figure 1.-Distribution of private ownerships, by form of ownership, Western United States, 1978 and 1994.
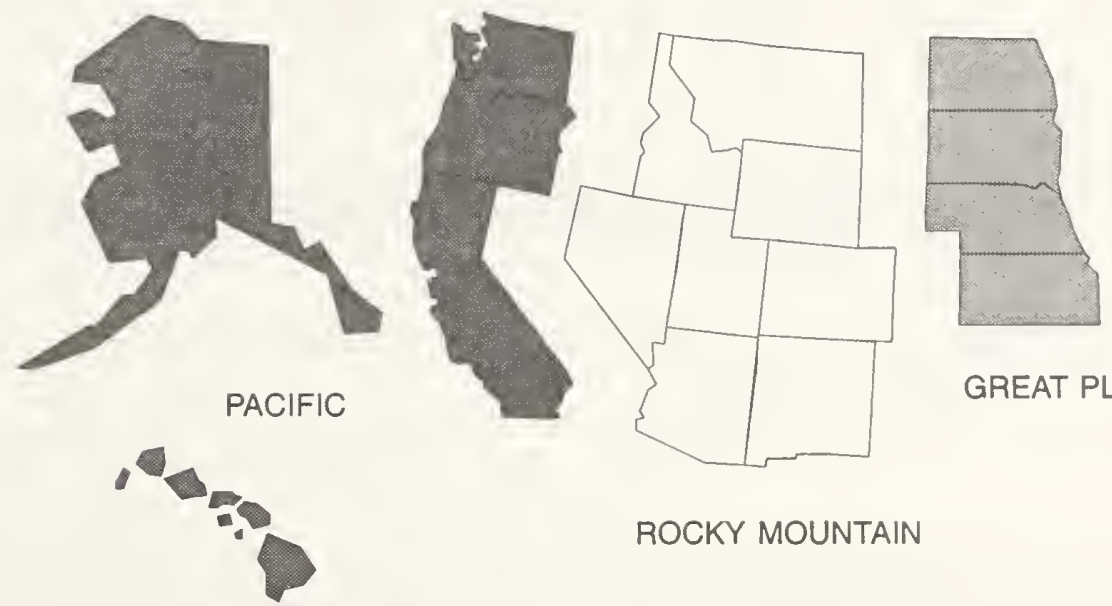

GREAT PLAINS

Figure 2.-Sub-regions of the West for private forest-land owners of the United States, 1994.

About 91 percent of the private ownerships in the West are individuals, collectively holding 33 percent of the privately owned forest land (Fig. 1, Table 1). Corporations hold 39 percent and the remaining 27 percent is held by partnerships, undivided estates, clubs, associations, and Indian Tribes.

Since 1978, individual ownerships, including joint husband and wife and family ownerships other than family corporations, increased in number but decreased in the proportion of private forest-land owners. The area owned by individuals increased and the proportion of forest land owned increased slightly. The current study includes a sample of Pinion-Juniper land in Oregon and California which was not included in the 1978 study and is owned primarily by individuals. Partnerships increased in number of ownership units but decreased in the proportion of private forest land owned. Both the number of corporations that own forest land and the forested acreage they hold increased, though the latter decreased in proportion to other ownership groups. Since 1978, "Other" ownerships such as sport and recreation clubs, undivided estates, trusts, and Indian Tribes increased both in number and in acreage held. Most of this increase resulted from the reclassification of Indian tribal lands as private that formerly were classified as Federal lands administered by the USDI Bureau of Indian Affairs. The other major change resulted from the distribution of lands to Native Corporations in Alaska. Indian Tribes, including Native Corporations, are a particularly important ownership group in Alaska, Arizona, New Mexico, Colorado, and several other states in the West. If the additional acreage of private "other forest" in Alaska not included in this report were added, private acreage in the West would total nearly 95 million acres.

The data in this report were presented at the regional and subregion level in Birch (1996). The West is divided into three subregions: Pacific, Rocky Mountain, and Plains States (Fig. 2, Table 2). Data tabulations by region, subregion, and state are presented at the end of this report. 

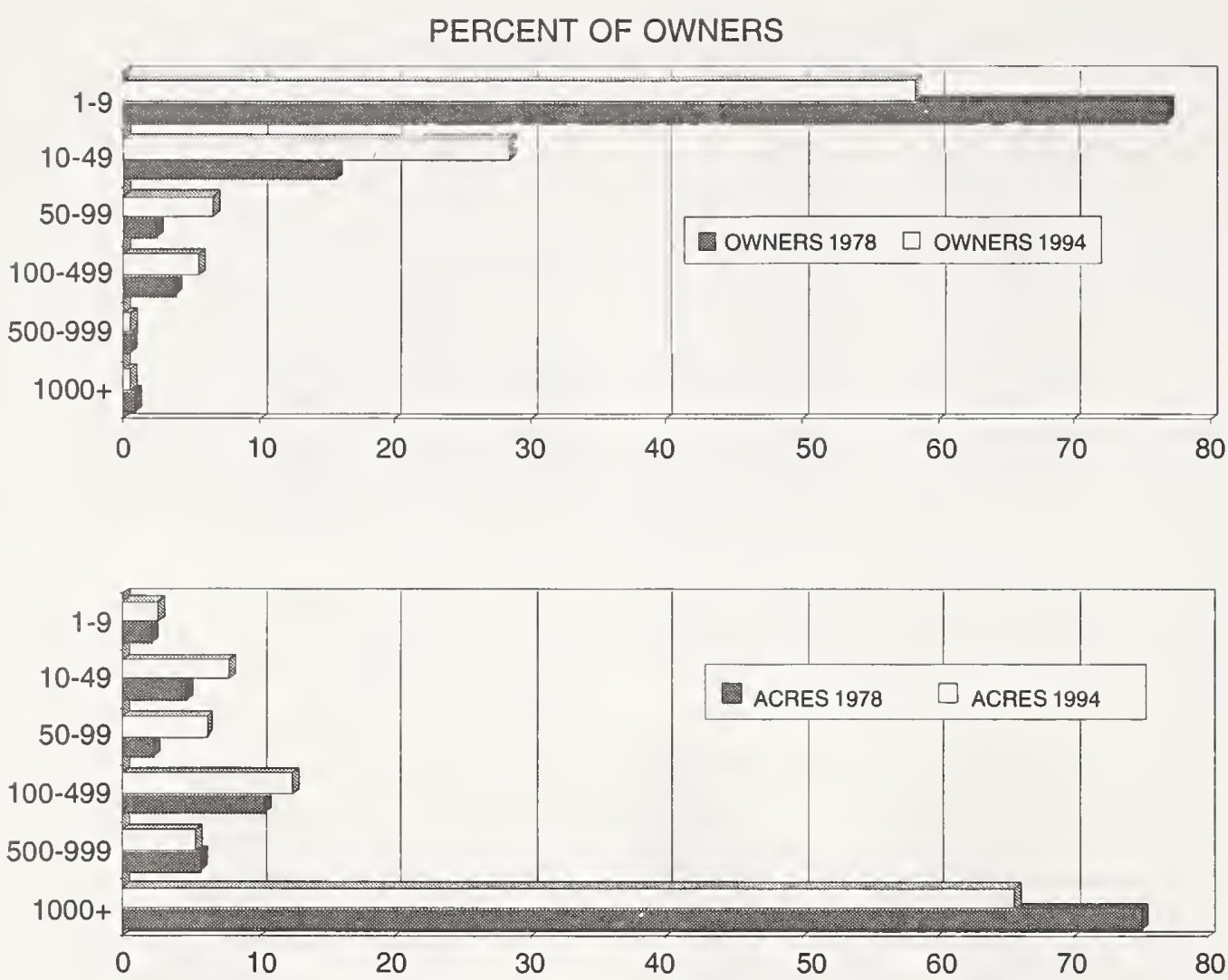

Figure 3.-Distribution of private ownerships, by size class of ownership, Western United States, 1978 and 1994.

The distribution of ownership by size class has changed since 1978 (Fig. 3, Table 3). The number of private ownerships with fewer than 10 acres of forest land increased from 474,000 (77 percent) to 601,000 (58 percent). The acreage in this class increased from 0.9 to 1.9 million acres. The number of ownerships with 10 to 49 acres of forest increased from 96,000 in 1978 to 293,000 in 1994. The acreage in this class increased from 2.2 to 5.9 million acres. The number of owners with 50 to 99 acres of forest increased from 15,000 to 68,000 and the acreage owned increased from 1.0 to 4.6 million acres from 1978 to 1994.

The area in ownerships of more than 100 acres is particularly important in the West. The proportion of ownerships with a written management plan increases with size of ownership. If the approximately 68,000 owners with more than 100 acres of forest worked with professional foresters, nearly 84 percent of the West's forest could be placed under management. However, working only with this group would preclude the development of a broad-based supportive constituency (Birch and Pywell 1986).

More than 93 percent of the private ownerships have fewer than 100 acres of forest land each; they control 16 percent of the private forest land. It is this portion of the resource where concern about fragmentation and rapid turnover is concentrated. While many of these owners did not cite timber harvesting as their primary reason for owning forest land, many have harvested and will harvest trees for sale to forest-products companies.

The implications of changing ownership patterns are significant. The yearly transition to many new forest-land owners makes it difficult to impart information about management and activities such as stewardship programs. As a result, the use of mass communication, particularly the electronic media, is essential (Birch and Pywell 1986). Nearly one-half of the current owners acquired forest land for the first time since 1978. These owners control 22 percent of the private forest land (Fig. 4, Table 4). The group with the largest decrease both in numbers of owners and acreage owned included people who had first acquired forest land between 1960 and 1969. The increase in ownerships and acres in the pre-1950 class resulted from the reclassification of Indian lands and fewer "no answer" responses.

The social and economic characteristics of private forestland owners and their objectives must be considered when developing management programs. As owners age, for example, some may harvest because they need money for 

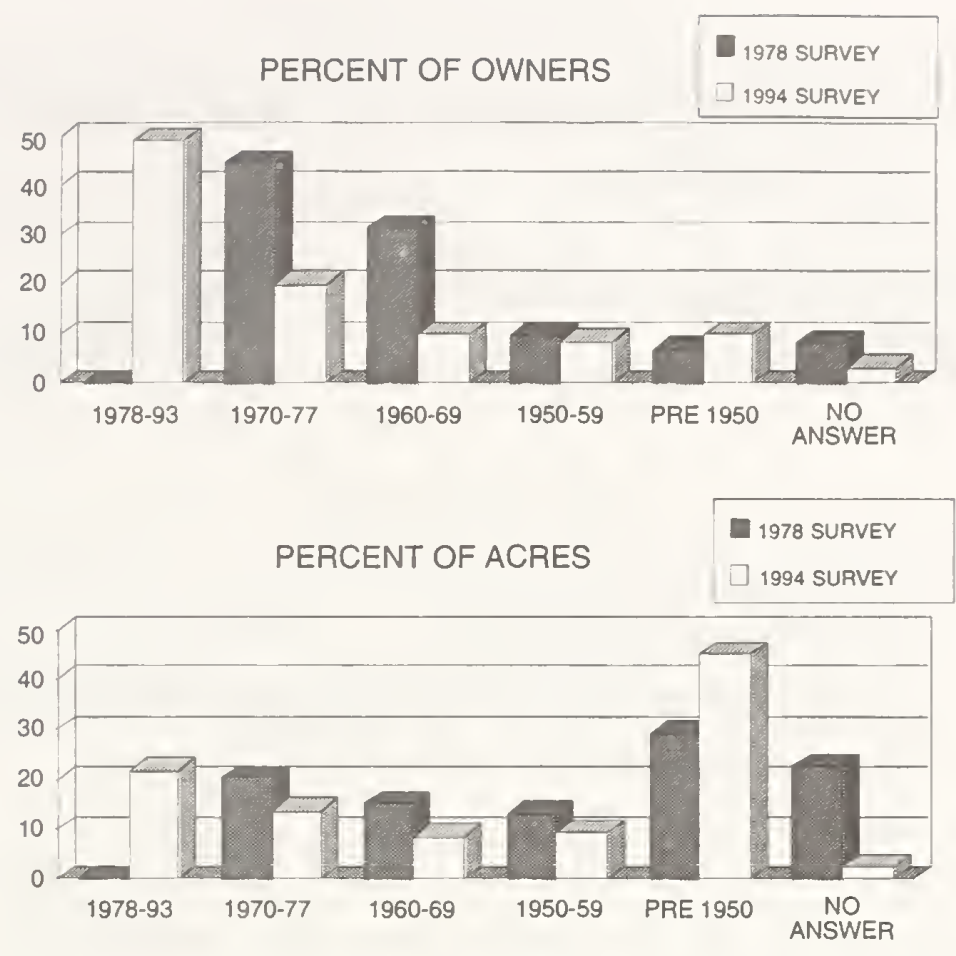

Figure 4.-Distribution of private ownerships, by year owner first acquired forest land, Western United States, 1978 and 1994.

retirement. By contrast, it is believed that "baby boomers" who are well known for their environmental concerns and high educational levels might not harvest because they do not need current income (Marcin and Skog 1984). But our studies revealed that the perception that owners are adverse to cutting trees is false.

In general, the "new" individual private forest-land owner is younger, better educated, and earns more than the owner of a decade ago. Also, the proportion of retired, farmer, and "other" owners increased (Fig. 5, Table 5). "Other" includes service workers, which coincides with the increase in service-related industries in the economy from 1978 to 1994. There has been a decrease in proportion of owners in "blue collar" occupations and a substantial decrease in the proportion of acreage held by these owners. The retired group increased both in the proportion of owners and proportion of acreage owned, possibly because owners who retired in the last decade were from occupation groups that had decreases as opposed to individuals who purchased forest land upon retirement. Also, people are retiring earlier and living longer.

\section{Owner Objectives}

Forests produce many benefits for their owners, so it is not surprising that land owners express diverse reasons for owning forest land. Many potential benefits from owning forest land are not competitive with each other: some are derived with little or no effect on others, while some even increase when another benefit is produced.

Nearly one-third of the private forest-land owners hold forest land primarily because it is "part of the farm" or "residence" (Fig. 6, Table 6). In general, these ownerships hold smaller than average-size tracts (fewer than 50 acres). Another 6 percent of the owners stated that farm or domestic use is the most important reason for owning forest land. Many of these owners consider their woodland as a source of fenceposts, fuelwood, and similar products.

Recreation and the enjoyment derived from owning forest land are the primary reasons why 29 percent of the owners hold forest land. The area owned by people with these objectives represents 12 percent of the private forest land.

Land investment often is thought of as a hedge against inflation. Private landowners who list land investment as the primary reason for owning account for 9 percent of the owners and 5 percent of private forest land.

Only 1 percent of the private forest-land owners hold their land primarily for timber production, but these owners control 30 percent of the private forest land. Some owners hold forest land for the minerals under the surface. Many of these are included in the "other" category. Also included in this category are lands owned by Indian Tribes and Native Corporations as part of their cultural heritage. 


\section{PERCENT OF OWNERS}

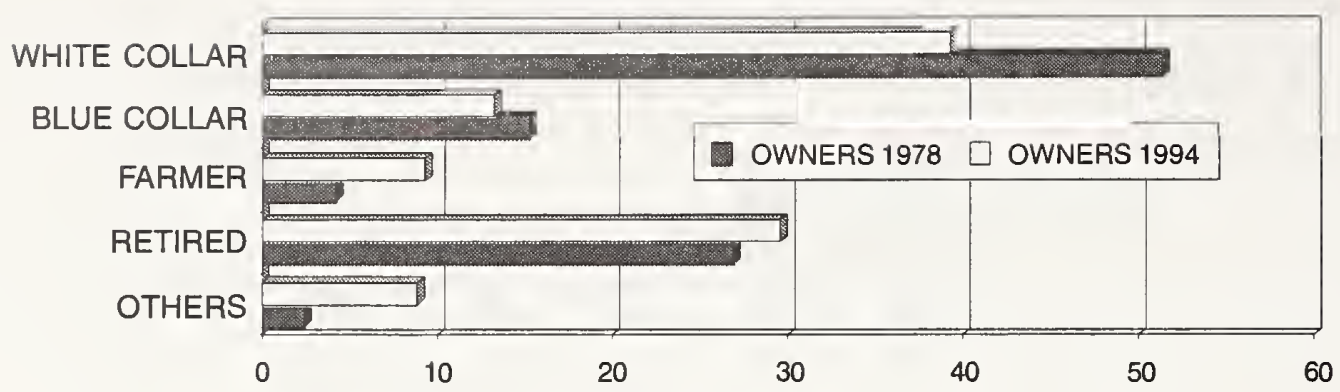

PERCENT OF ACRES

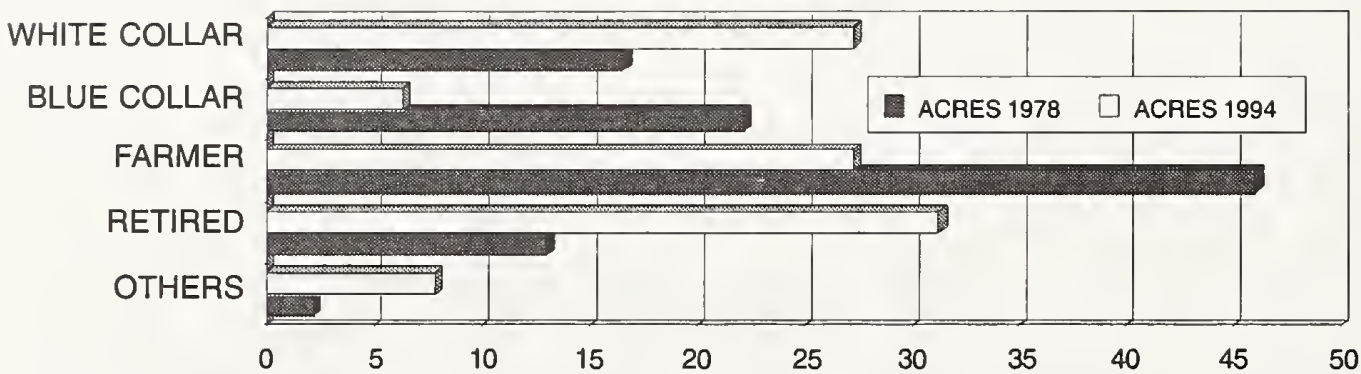

Figure 5.-Distribution of individual ownerships, by owner occupation, Western United States, 1978 and 1994.

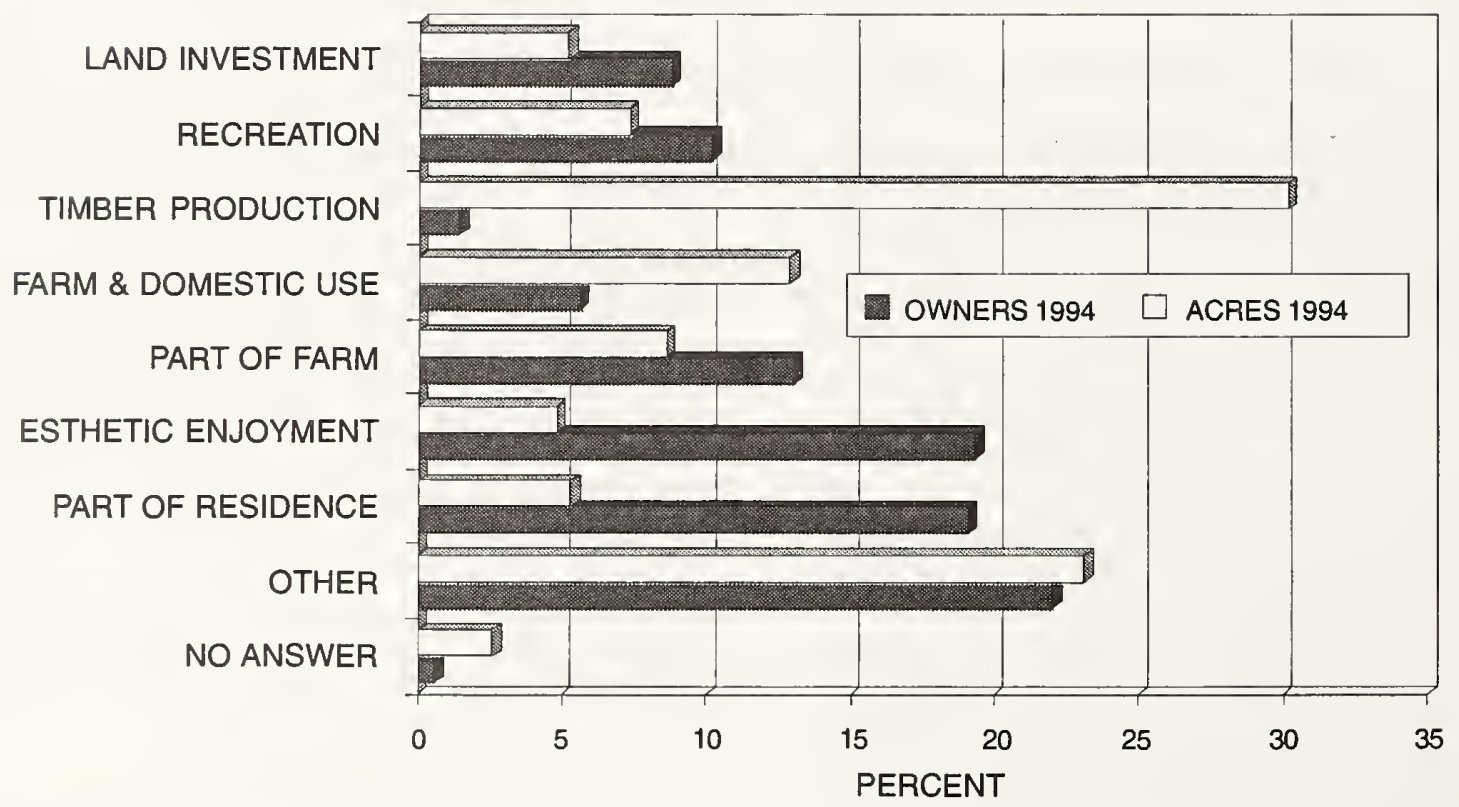

Figure 6.-Distribution of private ownerships, by primary reason for owning forest land, Western United States, 1994.

Benefits expected in the next 10 years provide another perspective on ownership objectives. Esthetic enjoyment predominates with 36 percent of the owners expecting it to be most important benefit (Table 7). These owners control 11 percent of the private forest.
Expected increases in land value is next in importance as a benefit, accounting for 18 percent of the owners and 8 percent of the private forest. Only 2 percent of the owners consider income from the sale of timber as the most important benefit; they control 33 percent of the private forest. Firewood is the most important benefit for 3 percent of the owners; they hold less than 1 percent of private forest land. 


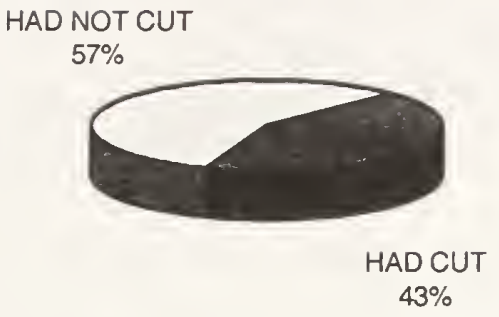

NONHARVESTERS

$18 \%$

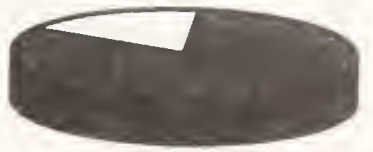

HARVESTERS

$82 \%$

Figure 7.- Harvest experience of private ownerships and acres of forest land, Western United States, 1994.

OWNERS 1994

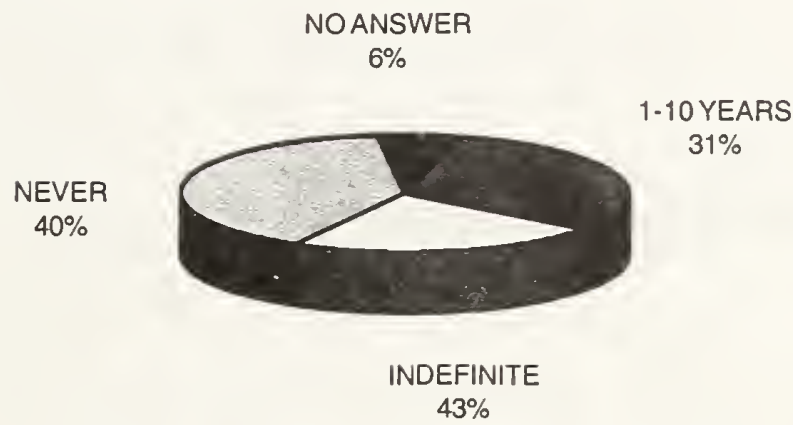

ACRES OWNED 1994

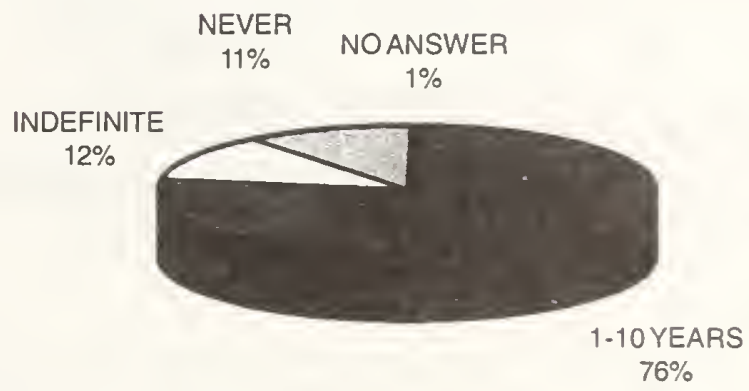

Figure 8. - Harvest intentions of private ownerships and acres of forest land owned, Western United States, 1994.

\section{Timber Harvesting Behavior}

There is a positive attitude toward and experience with timber harvesting. An estimated 46 percent of the private owners have harvesting experience; they control 78 percent of the private forest land (Fig. 7, Table 8).

Respondents stating that they intend to harvest in the next 10 years account for an estimated 32 percent of private forest-land owners and 76 percent of the private acreage. Conversely, 40 percent of the owners stated they never intend to harvest; they control only 11 percent of the private acreage (Fig. 8, Table 9). Owners with indefinite harvest plans (23 percent) control 12 percent of the private forest land.

\section{Management Planning}

With the advent of the Forest Stewardship Program, there is increased interest in written management plans. An estimated that 7 percent of the private forest-land owners have a written management plan for their acreage (Fig. 9 , Table 10). These owners control 53 percent of the private forest land.

Forest industry owns 40 percent of the forest land held by those with a written plan. The other 60 percent of the forest area is controlled by 75,800 nonindustrial private forest (NIPF) owners with some form of written plan. 


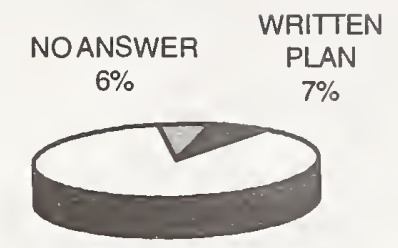

NO WRITTEN

PLAN

$87 \%$

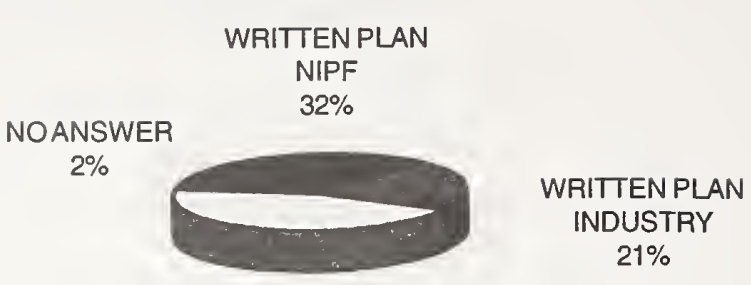

NO WRITTEN

PLAN

$45 \%$

Figure 9.-Distribution of private ownerships and acres of forest land owned, by whether a written management plan had been prepared, Western United States, 1994.

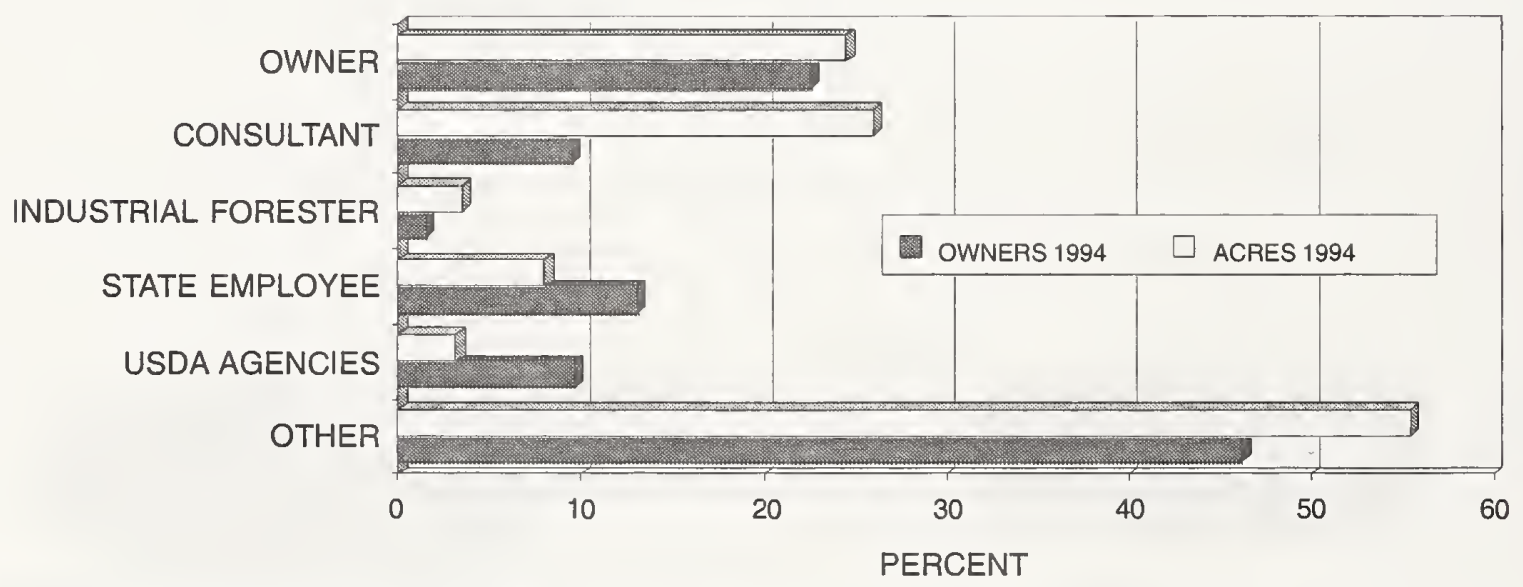

Figure 10.-Distribution of nonindustrial private ownerships and acres of forest land owned, by who prepared the written plan, Western United States, 1994.

Nearly 23 percent of the NIPF owners with a management plan prepared it themselves (Fig. 10, Table 11). These owners control 24 percent of the area covered by NIPF written plans. This includes some ownerships that employ foresters to prepare their plan. Nearly 10 percent of the NIPF plans were prepared by consultants, accounting for 26 percent of the forest land covered by written plans. Industrial foresters prepared about 2 percent of the NIPF plans covering an estimated 4 percent of the area covered by a written plans.

State service foresters and wildlife biologists have been preparing management plans for a long time. They wrote 13 percent of the plans for NIPF owners that cover 8 percent of the area under a written plan. Agencies such as the USDI Bureau of Indian Affairs, USDA Extension Service, and USDA Natural Resources Conservation Service prepared the remaining 55 percent of the plans that cover the remaining 59 percent of the forest under a management plan. Totals exceed 100 percent because some owners listed more than one agency or person preparing the plans.

\section{Conclusion}

The extent to which the private forest resources of the United States are needed, managed, and utilized in the future will depend on the complex set of interrelated factors that operated in the past. These include trends in the tastes and preferences of the owners of forest land; technological changes in the production, marketing, and utilization of wood products and their substitutes; strength of the American dollar, trade deficits, inflation, and other economic forces; attitudes of forest-land owners and other citizenry toward timber management and cutting; and attractiveness of local business climates and living environments to developing industries. Only time will tell how all of these factors interact. For now, watchful monitoring and good stewardship will be needed to maintain the productivity of forested ecosystems for future generations. 


\section{Literature Cited}

Barnard, J. E. 1978. FINSYS- tool for processing of integrated resource inventory data. In: Integrated inventories of renewable natural resources: Proceedings of the workshop. Gen Tech. Rep. RM-55. Fort Collins, CO: U.S. Department of Agriculture, Forest Service, Rocky Mountain Forest and Range Experiment Station: 332-335.

Birch, T. W. 1996. Private forest-land owners of the United States. Resour. Bull. NE-134. Radnor, PA: U.S. Department of Agriculture, Forest Service, Northeastern Forest Experiment Station. $183 \mathrm{p}$.

Birch, T. W.; Lewis, D. G.; Kaiser, H. F. 1982. The private forest-land owners of the United States. Resour. Bull. WO-1. Washington, DC: U.S. Department of Agriculture, Forest Service. $64 \mathrm{p}$.

Birch, T. W.; Pywell, N. A. 1986. Communicating with nonindustrial private forest-land owners: getting programs on target. Res. Pap. NE-593. Broomall, PA: U.S. Department of Agriculture, Forest Service, Northeastern Forest Experiment Station. 11 p.

Boxley, R. F. 1977. Land ownership issues in rural America. Publ. ERS 655. Washington, DC: U.S. Department of Agriculture, Economic Research Service. $8 \mathrm{p}$.

Lewis, J. A. 1980. Land ownership in the United States, 1978. Agric. Inf. Bull. 435. Washington, DC: U.S. Department of Agriculture. $98 \mathrm{p}$.
Marcin, T. C.; Skog, K. E. 1984. Demographic factors influencing future forest resource demands and policy and law. In: Forest resource management-the influence of policy and law: speeches and papers; 1984 August 6-7; Quebec, PQ. Quebec, PQ: International Forest congress: p. 279-285.

Powell, D. S.; Faulkner, J. L.; Darr, D. R.; Zhu, Z.; MacCleery, D. W. 1993. Forest resources of the United States, 1992. Gen. Tech. Rep. RM-234. Fort Collins, CO: U.S. Department of Agriculture, Forest Service, Rocky Mountain Forest and Range Experiment Station. $132 \mathrm{p}$.

U.S. Department of Agriculture, Forest Service. 1958. Timber resources for America's future. For. Resour. Rep. 14. Washington, DC: U.S. Department of Agriculture, Forest Service: p. 289-321.

U.S. Department of Agriculture, Forest Service. 1982. An analysis of the timber situation in the United States 1952-2030. For. Resour. Rep. 23. Washington, DC: U. S. Department of Agriculture, Forest Service. 489 p.

Wall, B. R. 1981. Trends in commercial timberland area in the United States by state and ownership 1952 1977 with projections to 2030. Gen Tech. Rep. WO-31 Washington, DC: U.S. Department of Agriculture, Forest Service. $26 \mathrm{p}$.

Wunderlich, G. 1978. Facts about U.S. Iand ownership. Agric. Inf. Bull. 422. Washington, DC: U.S. Department of Agriculture, Economics, Statistics, and Cooperatives Service. $29 \mathrm{p}$. 
Table 1. Estimated number and percentage of private ownership units and acres of forest land owned, by type of ownership, Western United States, 1978 and 1994

\begin{tabular}{|c|c|c|c|c|}
\hline \multirow[b]{2}{*}{ Ownership } & \multicolumn{2}{|c|}{1978} & \multicolumn{2}{|c|}{1994} \\
\hline & Thousands & Percent & Thousands & Percent \\
\hline & \multicolumn{4}{|c|}{ OWNERS } \\
\hline Individual & 583 & 94.5 & 936 & 90.9 \\
\hline Partnership & 22 & 3.6 & 39 & 3.7 \\
\hline Corporation & 10 & 1.6 & 25 & 2.5 \\
\hline Other & 2 & 0.3 & 30 & 2.9 \\
\hline \multirow[t]{2}{*}{ Total } & 617 & 100.0 & 1,030 & 100.0 \\
\hline & \multicolumn{2}{|c|}{1978} & \multicolumn{2}{|c|}{1994} \\
\hline \multirow[t]{2}{*}{ Ownership } & Millions & Percent & Millions & Percent \\
\hline & \multicolumn{4}{|c|}{ ACRES } \\
\hline Individual & 14.9 & 32.5 & 25.6 & 33.5 \\
\hline Partnership & 5.2 & 11.4 & 6.0 & 7.9 \\
\hline Corporation & 24.2 & 52.6 & 29.5 & 38.8 \\
\hline Other & 1.6 & 3.5 & 15.1 & 19.8 \\
\hline Total & 45.9 & 100.0 & 76.2 & 100.0 \\
\hline
\end{tabular}

Table 2. Estimated number of private ownership units and acres of forest land owned, by state and region, Western United States, 1978 and 1994

\begin{tabular}{|c|c|c|c|c|}
\hline \multirow[b]{2}{*}{$\begin{array}{l}\text { State, subregion, } \\
\text { and region }\end{array}$} & \multicolumn{2}{|c|}{1978} & \multicolumn{2}{|c|}{1994} \\
\hline & Owners & Acres & Owners & Acres \\
\hline & (Thousands) & (Millions) & (Thousands) & (Millions) \\
\hline Kansas & 31.8 & .751 & 39.3 & 1.291 \\
\hline Nebraska & 2.3 & .180 & 34.2 & .626 \\
\hline North Dakota & 1.9 & .330 & 11.3 & .411 \\
\hline South Dakota & 13.8 & .030 & 28.7 & .609 \\
\hline Great Plains & 49.8 & 1.291 & 113.5 & 2.937 \\
\hline Alaska & 0 & 0 & 16.6 & 9.881 \\
\hline California & 139.1 & 10.444 & 345.6 & 14.476 \\
\hline Hawaii & 2.0 & .697 & 24.8 & 1.155 \\
\hline Oregon & 164.5 & 10.130 & 166.2 & 10.650 \\
\hline Washington & 179.6 & 8.500 & 91.4 & 9.670 \\
\hline Pacific & 486.3 & 29.771 & 644.6 & 45.833 \\
\hline Arizona & .01 & .004 & 23.9 & 6.757 \\
\hline Colorado & 53.3 & 2.407 & 55.6 & 3.286 \\
\hline Idaho & 21.7 & 3.110 & 47.4 & 3.245 \\
\hline Montana & 4.8 & 5.910 & 82.7 & 5.957 \\
\hline Nevada & .1 & .074 & 14.8 & .530 \\
\hline New Mexico & .1 & 1.489 & 24.6 & 4.129 \\
\hline Utah & 1.7 & 1.179 & 14.6 & 1.537 \\
\hline Wyoming & .2 & .671 & 8.5 & 1.997 \\
\hline Rocky Mountain & 81.9 & 14.844 & 272.2 & 27.418 \\
\hline West & 616.9 & 45.906 & $1,030.3$ & 76.187 \\
\hline Nation & $7,757.9$ & 333.094 & $9,901.7$ & 393.389 \\
\hline
\end{tabular}


Table 3. Estimated number and percentage of private ownership units and acres of forest land owned, by size class of ownership, Western United States, 1978 and 1994

\begin{tabular}{|c|c|c|c|c|}
\hline \multirow[b]{2}{*}{ Size class (acres) } & \multicolumn{2}{|c|}{1978} & \multicolumn{2}{|c|}{1994} \\
\hline & Thousands & Percent & Thousands & Percent \\
\hline & \multicolumn{4}{|c|}{ OWNERS } \\
\hline $1-9$ & 474 & 76.9 & 601 & 58.3 \\
\hline $10-49$ & 96 & 15.6 & 293 & 28.4 \\
\hline $50-99$ & 15 & 2.4 & 68 & 6.6 \\
\hline $100-499$ & 24 & 3.8 & 56 & 5.5 \\
\hline $500-999$ & 3 & 0.5 & 6 & 0.6 \\
\hline $1000+$ & 5 & 0.8 & 6 & 0.6 \\
\hline \multirow[t]{2}{*}{ Total } & 617 & 100.0 & 1,030 & 100.0 \\
\hline & \multicolumn{2}{|c|}{1978} & \multicolumn{2}{|c|}{1994} \\
\hline \multirow[t]{2}{*}{ Size class (acres) } & Millions & Percent & Millions & Percent \\
\hline & \multicolumn{4}{|c|}{ ACRES } \\
\hline $1-9$ & 0.9 & 2.1 & 1.9 & 2.6 \\
\hline $10-49$ & 2.2 & 4.7 & 5.9 & 7.8 \\
\hline $50-99$ & 1.0 & 2.2 & 4.6 & 6.1 \\
\hline $100-499$ & 4.8 & 10.4 & 9.5 & 12.4 \\
\hline $500-999$ & 2.6 & 5.6 & 4.1 & 5.4 \\
\hline $1000+$ & 34.4 & 75.0 & 50.1 & 65.7 \\
\hline Total & 45.9 & 100.0 & 76.1 & 100.0 \\
\hline
\end{tabular}

Table 4. Estimated number and percentage of private ownership units and acres of forest land owned, by date of acquisition, Western United States, 1978 and 1994

\begin{tabular}{|c|c|c|c|c|}
\hline \multirow[b]{2}{*}{ Date of acquisition } & \multicolumn{2}{|c|}{1978} & \multicolumn{2}{|c|}{1994} \\
\hline & Thousands & Percent & Thousands & Percent \\
\hline & \multicolumn{4}{|c|}{ OWNERS } \\
\hline $1978-93$ & 0 & 0 & 504 & 48.9 \\
\hline $1970-77$ & 275 & 44.5 & 204 & 19.8 \\
\hline $1960-69$ & 192 & 31.1 & 101 & 9.8 \\
\hline $1950-59$ & 59 & 9.6 & 87 & 8.5 \\
\hline Prior to 1950 & 41 & 6.7 & 101 & 9.8 \\
\hline No answer & 50 & 8.1 & 33 & 3.2 \\
\hline \multirow[t]{2}{*}{ Total } & 617 & 100.0 & 1,030 & 100.0 \\
\hline & \multicolumn{2}{|c|}{1978} & \multicolumn{2}{|c|}{1994} \\
\hline \multirow[t]{2}{*}{ Date of acquisition } & Millions & Percent & Millions & Percent \\
\hline & \multicolumn{4}{|c|}{ ACRES } \\
\hline $1978-93$ & 0 & 0 & 16.4 & 21.6 \\
\hline $1970-77$ & 9.2 & 20.1 & 10.4 & 13.6 \\
\hline $1960-69$ & 6.9 & 15.0 & 6.3 & 8.3 \\
\hline $1950-59$ & 6.0 & 13.1 & 7.1 & 9.2 \\
\hline Prior to 1950 & 13.4 & 29.2 & 34.2 & 44.9 \\
\hline No answer & 10.4 & 22.6 & 1.8 & 2.4 \\
\hline Total & 45.9 & 100.0 & 76.2 & 100.0 \\
\hline
\end{tabular}


Table 5. Estimated number and percentage of private ownership units and acres of forest land owned, by owner's occupation, Western United States, 1978 and 1994

\begin{tabular}{|c|c|c|c|c|}
\hline \multirow[b]{2}{*}{ Occupation } & \multicolumn{2}{|c|}{1978} & \multicolumn{2}{|c|}{1994} \\
\hline & Thousands & Percent & Thousands & Percent \\
\hline & \multicolumn{4}{|c|}{ OWNERS } \\
\hline White collar & 299 & 51.3 & 367 & 39.2 \\
\hline Blue collar & 89 & 15.2 & 124 & 13.2 \\
\hline Farmer & 24 & 4.2 & 87 & 9.3 \\
\hline Retired & 157 & 26.9 & 276 & 29.5 \\
\hline Other & 14 & 2.4 & 82 & 8.8 \\
\hline \multirow[t]{2}{*}{ Total, individuals } & 583 & 100.0 & 936 & 100.0 \\
\hline & \multicolumn{2}{|c|}{1978} & \multicolumn{2}{|c|}{1994} \\
\hline \multirow[t]{2}{*}{ Occupation } & Millions & Percent & Millions & Percent \\
\hline & \multicolumn{4}{|c|}{ ACRES } \\
\hline White collar & 2.5 & 16.6 & 7.0 & 27.3 \\
\hline Blue collar & 3.3 & 22.2 & 1.6 & 6.3 \\
\hline Farmer & 6.9 & 46.0 & 7.0 & 27.3 \\
\hline Retired & 1.9 & 13.0 & 8.0 & 31.3 \\
\hline Other & 0.3 & 2.2 & 2.0 & 7.8 \\
\hline Total, individuals & 14.9 & 100.0 & 25.6 & 100.0 \\
\hline
\end{tabular}

Table 6. Estimated number and percentage of private ownership units and acres of forest land owned, by primary reason for owning forest land, Western United States, 1994

\begin{tabular}{lccrrr}
\hline & \multicolumn{2}{c}{ Owners } & & \multicolumn{2}{c}{ Acres } \\
\cline { 2 - 3 } \cline { 5 - 6 } Reason for owning & Thousands & Percent & & Millions & Percent \\
\hline Land investment & 90.9 & 8.8 & & 4.0 & 5.2 \\
Recreation & 104.3 & 10.2 & & 5.5 & 7.3 \\
Timber production & 14.8 & 1.4 & & 23.1 & 30.2 \\
Farm and domestic use & 57.6 & 5.6 & & 9.8 & 12.9 \\
Enjoyment of owning & 199.1 & 19.3 & & 3.7 & 4.8 \\
Part of farm & 134.2 & 13.0 & & 6.6 & 8.6 \\
Part of residence & 197.3 & 19.1 & & 4.0 & 5.3 \\
Other & 226.3 & 22.0 & & 17.5 & 23.1 \\
No answer & 5.7 & 0.6 & & 2.0 & 2.6 \\
\cline { 2 - 3 } Total & $1,030.3$ & 100.0 & 76.2 & 100.0 \\
\hline
\end{tabular}


Table 7. Estimated number and percentage of private ownership units and acres of forest land owned, by primary benefit expected in the next 10 years from owning forest land, Western United States, 1994

\begin{tabular}{|c|c|c|c|c|}
\hline \multirow[b]{2}{*}{ Expected benefit } & \multicolumn{2}{|c|}{ Owners } & \multicolumn{2}{|c|}{ Acres } \\
\hline & Thousands & Percent & Millions & Percent \\
\hline Land value increase & 181.4 & 17.6 & 5.7 & 7.5 \\
\hline Recreation & 121.4 & 11.8 & 7.5 & 9.8 \\
\hline Timber production & 21.4 & 2.1 & 25.2 & 33.1 \\
\hline Farm and domestic use & 121.5 & 11.8 & 11.4 & 15.0 \\
\hline Enjoyment of owning & 365.3 & 35.5 & 8.7 & 11.4 \\
\hline Firewood & 26.9 & 2.6 & 0.5 & 0.7 \\
\hline Other & 119.1 & 11.6 & 13.5 & 17.7 \\
\hline No answer & 73.3 & 7.1 & 3.7 & 4.9 \\
\hline Total & $1,030.3$ & 100.0 & 76.2 & 100.0 \\
\hline
\end{tabular}

Table 8. Estimated number and percentage of private ownership units and acres of forest land owned, by harvest experience, Western United States, 1994

\begin{tabular}{|c|c|c|c|c|}
\hline \multirow[b]{2}{*}{ Harvest experience } & \multicolumn{2}{|c|}{ Owners } & \multicolumn{2}{|c|}{ Acres } \\
\hline & Thousands & Percent & Millions & Percent \\
\hline Harvesters & 439.4 & 42.6 & 62.9 & 82.5 \\
\hline Nonharvesters & 590.9 & 57.4 & 13.3 & 17.5 \\
\hline Total & $1,030.3$ & 100.0 & 76.2 & 100.0 \\
\hline
\end{tabular}

Table 9. Estimated number and percentage of private ownership units and acres of forest land owned, by expected time of future harvest, Western United States, 1994

\begin{tabular}{lccccr}
\hline & \multicolumn{2}{c}{ Owners } & & \multicolumn{2}{c}{ Acres } \\
\cline { 2 - 3 } \cline { 5 - 6 } Intention to harvest & Thousands & Percent & & Millions & Percent \\
\hline 1-10 years & 324.1 & 31.5 & & 58.0 & 76.1 \\
Indefinite & 236.4 & 22.9 & & 9.1 & 12.0 \\
Never & 407.9 & 39.6 & & 8.2 & 10.7 \\
No answer & 61.9 & 6.0 & & 0.9 & 1.2 \\
Total & $1,030.3$ & 100.0 & 76.2 & 100.0 \\
\hline
\end{tabular}


Table 10. Estimated number of private ownership units and acres of forest land owned, by whether a written management plan had been prepared, United States, 1994

\begin{tabular}{lccccc}
\hline & \multicolumn{2}{c}{ Owners } & & \multicolumn{2}{c}{ Acres } \\
\cline { 2 - 3 } \cline { 6 - 6 } $\begin{array}{l}\text { Preparation of } \\
\text { management plan }\end{array}$ & Thousands & Percent & & Millions & Percent \\
\hline Owners with written plans: & 76.2 & 7.4 & & 40.0 & 52.6 \\
$\quad$ & 0.4 & 0.5 & & 16.2 & 40.5 \\
$\quad$ Forest industry & 75.8 & 99.5 & & 23.8 & 59.5 \\
$\quad$ NIPF owners & 898.6 & 87.2 & & 34.7 & 45.5 \\
Owners with no written plan & 55.5 & 5.4 & & 1.5 & 1.9 \\
No answer & $1,030.3$ & 100.0 & 76.2 & 100.0 \\
Total & & &
\end{tabular}

Table 11. Estimated number and percentage of private ownership units and acres of forest land owned, by who prepared the written management plan for NIPF owners, Western United States, 1994

\begin{tabular}{|c|c|c|c|c|}
\hline \multirow[b]{2}{*}{$\begin{array}{l}\text { Preparation of } \\
\text { management plan }\end{array}$} & \multicolumn{2}{|c|}{ Owners } & \multicolumn{2}{|c|}{ Acres } \\
\hline & Thousands & Percent & Millions & Percent \\
\hline $\begin{array}{l}\text { NIPF owners with } \\
\text { written plans }\end{array}$ & $75.8=$ & 100.0 & 23.8 & 100.0 \\
\hline \multicolumn{5}{|l|}{ Who prepared the plan } \\
\hline Owner & 17.1 & 22.6 & 5.8 & 24.5 \\
\hline Consultant & 7.2 & 9.5 & 6.2 & 26.0 \\
\hline Industrial forester & 1.2 & 1.5 & 0.8 & 3.5 \\
\hline State employee & 9.9 & 13.0 & 1.9 & 8.0 \\
\hline Extension & 0.5 & 0.7 & 0.1 & 0.2 \\
\hline NRCS & 6.8 & 8.9 & 0.7 & 2.9 \\
\hline Other & 35.0 & 46.2 & 13.2 & 55.4 \\
\hline Total $^{b}$ & 77.7 & 102.8 & 28.7 & 120.6 \\
\hline
\end{tabular}

a National Resources Conservation Service.

b Totals exceed 100 percent because some plans prepared by more than one person. 


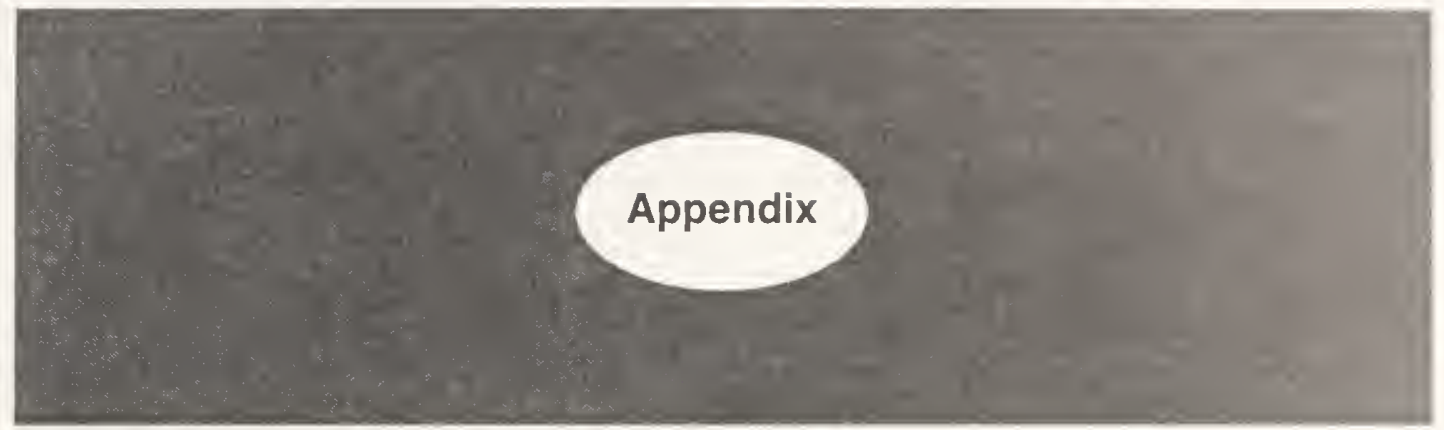

\section{Study Method}

The sampling scheme used in this study was derived from the sampling design used by the USDA Forest Service's, FIA projects and that used by the NRCS's NRI. Mailing addresses were obtained for the owners of forested land on which a sample location from one of the two inventory systems was located. These addresses were obtained by crews from the forest inventory projects or from cooperating state forestry agencies. The names were obtained from a variety of sources--tax offices, other government agencies, neighbors, or the owner. Usable addresses were obtained for more than 95 percent of the sample locations. Of the 30,870 locations chosen, 2,602 were in some form of public ownership. Many large ownerships were identified that had multiple sample locations. Efforts were made to send only one questionnaire per state to these large owners. In all, 23,330 questionnaires were sent to owners of forest land; 11,745 (50 percent) were returned with usable information.

The questionnaire, was derived from several earlier ownership studies, has been revised as work has progressed over 20 years in the Northeastern States. A copy of the 4-page, 18-question questionnaire is included in this report. The mailing consisted of a questionnaire and cover letter explaining the purpose of the study.

Approximately 3 weeks after the first mailing, a second questionnaire was mailed to those who had not responded with a second letter urging their cooperation. Approximately 1 month after the final followup mailing, a field followup of nonrespondents was conducted to obtain additional questionnaires and provide a basis for determining whether there was a significant difference between those who returned a questionnaire and those who did not. Questionnaires obtained by mail and followup were used in the same way for estimation. Many state forestry organizations had local service foresters contact nonrespondents. Where state organizations were unable to assist with followups, Forest Service personnel and volunteers made the contacts.

\section{Estimation Procedure}

The probability that a forest-land owner will be sampled depends on the rate of sampling and the acreage of forest land owned. Each state and often areas within states have different rates of sampling. Also, response rates differ, affecting the probability that an owner will be included in the final tabulations. The total acreage of forest land in private ownership for a state or sampled area is obtained from the forest inventory. The area in large ownerships, ownerships with a probability of selection approaching 1 , is subtracted and the large ownerships form a separate strata. The remaining forest land is divided by the number of "small acreage" sample locations represented by the remaining valid questionnaires to determine the area represented by each sample plot.Since the sampling scheme is essentially the one used for the forest inventory, there is a low probability of inclusion for owners of small parcels of forest land. To estimate the total number of persons or ownership units, it is necessary to weight the number of owners in the sample. This procedure can be stated as:

$$
N=\frac{T_{p}}{n_{r}} \sum \frac{1}{A_{i}}
$$

$N=$ estimated number of private owners in the sampling strata.

$T_{p}=$ acres of forest land in the sampling strata

$n_{r}=$ number of respondents in the sampling strata

$A i=$ acres owned by individual respondents

The summation estimate equals the estimated number of ownership units in the state, region, or nation. This is an unbiased estimate of the total number of ownership units that own forest land. The data were edited, processed, and compiled using FINSYS-2, a generalized computer system (Barnard 1978). The survey units within states were combined to state level statistics. States were summed to regions and finally to national summaries to increase the accuracy and precision of the estimates. The following tabulation shows the pertinent data for each state, region, and the nation. 


\begin{tabular}{lcrrrr}
$\begin{array}{l}\text { States, subregions, } \\
\text { and region private }\end{array}$ & $\begin{array}{c}\text { Number of } \\
\text { plots }\end{array}$ & $\begin{array}{c}\text { Number of } \\
\text { questionnaires } \\
\text { sent }\end{array}$ & $\begin{array}{c}\text { Number of } \\
\text { respondents }\end{array}$ & $\begin{array}{c}\text { No. plots } \\
\text { owned by } \\
\text { respondents }\end{array}$ & $\begin{array}{c}\text { Ave. no. } \\
\text { acres per } \\
\text { plot }\end{array}$ \\
\hline Kansas & 164 & 146 & 38 & 38 & 33,974 \\
Nebraska & 141 & 137 & 27 & 27 & 23,185 \\
North Dakota & 119 & 117 & 30 & 30 & 13,700 \\
South Dakota & 88 & 80 & 17 & 18 & 33,833 \\
Great Plains & 512 & 480 & 112 & 113 & 25,991 \\
\hline Alaska & 380 & 78 & 35 & 226 & 43,721 \\
California & 737 & 629 & 355 & 438 & 33,050 \\
Hawaii & 49 & 28 & 16 & 27 & 42,778 \\
Oregon & 844 & 519 & 335 & 612 & 17,402 \\
Washington & 654 & 296 & 188 & 536 & 18,041 \\
Pacific & 2664 & 1550 & 928 & 1839 & 24,923 \\
\hline Arizona & 93 & 21 & 11 & 72 & 93,847 \\
Colorado & 175 & 147 & 83 & 97 & 33,876 \\
Idaho & 67 & 41 & 31 & 58 & 55,948 \\
Montana & 226 & 148 & 81 & 156 & 38,186 \\
Nevada & 69 & 45 & 17 & 19 & 27,895 \\
New Mexico & 210 & 136 & 66 & 128 & 32,258 \\
Utah & 83 & 66 & 29 & 35 & 43,914 \\
Wyoming & 93 & 83 & 59 & 67 & 29,806 \\
Rocky Mountain & 1016 & 687 & 377 & 632 & 43,383 \\
\hline West & 4,192 & 2,717 & 1,417 & 2,584 & 29,484 \\
\hline \hline Nation & 28,207 & 23,330 & 11,745 & 15,700 & 25,057 \\
\hline
\end{tabular}

\section{Data Accuracy and Reliability}

It is important to know the variation associated with the estimates. Not every acre and owner are sampled. When judging the effectiveness of the estimating procedure, we are concerned with two important criteria: how accurate is the estimate, and how precise is the estimate? Accuracy is the correspondence between the sample result and the result from a complete count or census using the same definitions and procedures. Reliability is the precision of the statistical estimates. We are interested primarily in the accuracy of the sample but in most instances we can only measure reliability.

To check the accuracy of the data, we had outside experts review this report. The response level obtained in the study also is an attempt to assure accuracy by minimizing nonresponce bias. Beyond the search for accuracy, the reliability of the estimate is given by the calculated sampling errors. Sampling errors are calculated for the estimated number of forest-land ownership units and the acreage of forest land in each cell of the tables. Sampling errors are included in the tables for the most important categories. The sampling error for the number of acres of forest land in private ownership is calculated as part of the forest inventory and is designed to achieve a national standard of plus or minus 3 percent at a million acres of forest land. Because this study has a much smaller sample size than the normal forest inventory, sampling errors rise rapidly for smaller areas of forest land. There is no similar standard for the estimates of forest-land ownership units.

Because the ownership survey was conducted using a landarea sample, the estimates of area have smaller sampling errors than those of numbers of owners. Estimates for the Nation as a whole are the most reliable (having the smallest sampling errors in percent), followed by regions, subregions, and states. The inclusion of small forest parcels (fewer than 10 acres) in the study population substantially increases the sampling error for the estimated number of owners. In discussions with representatives of the National Association of State Foresters and other users, most believed that the level of precision achieved by the Northeastern Forest Experiment Station was sufficient. Because the accuracy of estimates at the state level from the previous national forest-land owner study were insufficient, we allocated increased sample sizes to areas of the country with high sampling errors in an attempt to overcome this problem. The following are sampling errors (in percent). 
State, subregion, and region
Private forest land
Owners of private forest land
Owners holding 10 or more acres

\begin{tabular}{lccc}
\hline Kansas & 0.4 & 35.0 & 17.3 \\
Nebraska & 0.6 & 67.1 & 26.2 \\
North Dakota & 1.0 & 40.6 & 22.6 \\
South Dakota & 0.4 & 46.3 & 42.2 \\
\cline { 2 - 4 } Great Plains & 0.3 & 26.6 & 13.2 \\
\hline California & 0.3 & 16.9 & 10.0 \\
Hawaii & 0.2 & 53.5 & 51.1 \\
Oregon & 1.5 & 18.7 & 9.7 \\
Washington & 1.2 & 27.0 & 10.4 \\
Pacific Coast & 0.4 & 11.2 & 6.8 \\
\hline Arizona & 1.4 & 47.3 & 56.0 \\
Colorado & 0.4 & 30.1 & 24.5 \\
Idaho & 0.8 & 55.4 & 32.2 \\
Montana & 0.8 & 28.0 & 24.9 \\
Nevada & 0.5 & 64.1 & 42.9 \\
New Mexico & 0.3 & 31.7 & 31.6 \\
Utah & 0.3 & 52.4 & 41.8 \\
Wyoming & 0.4 & 28.1 & 28.1 \\
Rocky Mountain & 0.2 & 15.8 & 12.9 \\
\hline West & 0.3 & 8.7 & 5.8 \\
\hline \hline Nation & 0.1 & 3.4 & 1.6 \\
\hline
\end{tabular}

\section{Definition of Terms}

Farmer-owned lands. Lands owned by farm operators, whether part of the farmstead of not.

Forest industries. Companies or individuals operating primary wood-using plants.

Forest industry lands. Lands owned by companies of individuals operating wood-using plants.

Forest land. Land that is at least 16.7 percent stocked (contains at least 7.5 square feet of basal area) by forest trees of any size, or that formerly had such tree cover and is not currently developed for nonforest use. (Forest trees are woody plants that have a welldeveloped stem and usually are more than 12 feet in height at maturity.) The minimum area for classification of forest land is one acre.
Ownership unit. All types of legal entities having ownership interest in land, regardless of the number of people involved. It is the locus of decision making for each parcel, whether an individual (sole proprietor), group of individuals (partnerships, or undivided estates), or legal entity (corporation, trust, or tribe).

Private timberland. All timberland other than that owned by Federal, state, or local governments or their agencies.

Timberland. Forest land that is producing or capable of producing crops of industrial wood (more than 20 cubic feet/acre/year) and that is not withdrawn from timber utilization.

Other forest. Forest land other than timberland, including: oak woodlands in western Texas and Oklahoma; Juniper woodlands in California and Oregon, Pinon Juniper land in the Rocky Mountains, and much of interior Alaska. 
NE FOREST EXPERIMENT STATION FOREST SERVICE

U.S. DEPT. OF AGRICULTURE
Form Approved

OMB No. 0596-0078

Expires: 6-30-94
State

County

Plot

\section{NATIONAL SURVEY OF FOREST-LAND OWNERSHIP}

THIS SURVEY IS VOLUNTARY AND THERE ARE NO PENALTIES FOR REFUSING TO ANSWER ANY QUESTIONS. BECAUSE IT WOULD INVOLVE A TREMENDOUS COST TO THE TAXPAYERS WE ARE UNABLE TO CONTACT ALL WOODLAND OWNERS. THEREFORE, WE TAKE A SMALL BUT REPRESENTATIVE SAMPLE OF WOODLANDS, ONE OF WHICH HAPPENS TO BE YOURS. SINCE YOU REPRESENT HUNDREDS OF OTHER WOODLAND OWNERS, YOUR COOPERATION IS IMPORTANT TO MAKE THE SURVEY RESULTS COMPREHENSIVE, ACCURATE, AND TIMELY. THANK YOU.

Please complete the following questions. Where actual records are not available please use your best estimate. Please be assured your answers will be strictly confidential, only statistical tabulations will be published. If you do not now own woodland, please answer question 1 and return the questionnaire.

1. In what states do you own land?

State

Total

acres
Acres*

wooded

* Include idle fields and pastures with young trees.

2. How many individual tracts or parcels of woodland do you now own?

number

3. In what year did you first acquire woodland? (Whether or not you still own the first tract you acquired.)

$$
\text { year }
$$

How much woodland have you acquired in the last 12 years? acres

How much woodland have you disposed of (sold or deeded to others) in the last 12 years?

acres

4. In which of the following ownership categories does the major portion of your woodland holding fall?

Individual (including joint husband 1 wife and family ownerships other than family corporations)

Partnership

Corporate

Club or association

Other (Please specify
2 .

3.

4.

5 . check only one.)$$
\text { . }
$$

. 
5. If your ownership has a business or association with it, what is the nature of the organization:

Check one

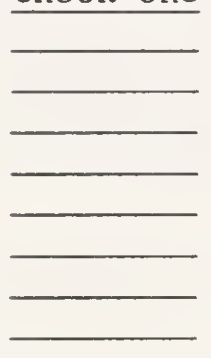

Forest industry (sawmill, pulpmill, etc.)

Farm

Industrial business (manufacturing, mineral extraction, etc.)

Real estate

Non-industrial business (retail, sales, service industry, etc.)

Sport/recreation club or association

Public utility

Other (please specify

6. What is the approximate road mileage from your primary residence to your nearest and farthest tract of woodland? (For businesses or organizations consider primary residence to mean nearest place of business.)

Miles to the nearest tract

(enter zero if you live on the tract)

Miles to farthest tract

7. Have trees been harvested from your land, either by you personally or by someone else, during the time you have owned your woodland?

Yes 1 .

Year of the most recent harvest

No. 2 .

8. During the cutting, what products were harvested? (Check as many as apply.)

Check

1. Fuelwood for your own use or for the use of friends

2. - Other products for personal use (fence posts, lumber, etc.)

3. Fuelwood for sale

4. Sawlogs for sale

5. Pulpwood for sale

6. Posts, poles, and pilings for sale

7. Christmas trees for sale

8. - Other products (please specify

9. - Don't know what products were harvested

9. Do you plan to cut or harvest trees from your land for your personal use or for sale?

In the next 10 years?

Possibly at some future date?

Never plan to harvest?

$\frac{\text { Wood for own use }}{\text { (Check one) }} \quad \frac{\text { Wood for sale }}{\text { (Check one) }}$

1 .

2.

3.

4.

5.

6.

10. Is there a written forestry or wildlife management plan for your property?
1. Yes
2. No

If yes, who prepared the plan?

1. I prepared the plan.

2. Other, please specify 
11. Have you ever sought advice or assistance in managing your woodland?

$$
\text { 1. Yes_ 2. No }
$$

12. What office, agency, or individual would you contact for forestry help or advice? (If you don't know, please check "Don't Know".)

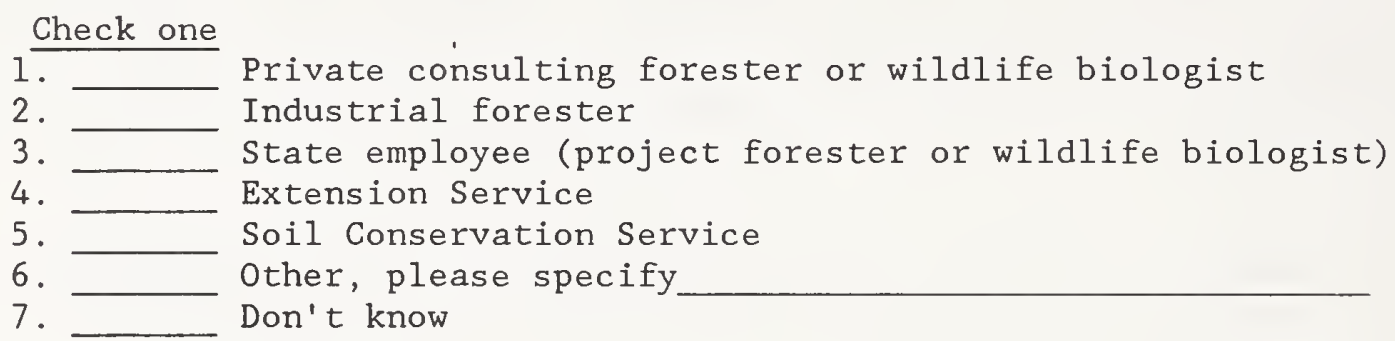

13. What types of assistance or improvements would you be willing to pay for? Please specify

14. Why do you own woodland? (Please rank with number 1 the most important.)
1.
Land investment (hope to sell all or most of my woodland at a profit)
3.
3.
2.
Recreation (hunting, camping, fishing, bird watching, etc.)
Timber production (growing timber or other forest products for sale)
4.
5.
Farm or domestic use (having the woods as a source of timber for my own use, e.g., firewood, fence posts, etc.)
6. Enjoyment of owning "green space"
Part of the farm (woodland is the untillable part of the
7.
8. farm and serves no useful funct
Woodland is part of my residence
9 .
For an estate to pass on to my children
Other (please specify

15. Which of the following do you feel will be the most important benefits you expect to derive from your woodland during the next 10 years? (Please rank these benefits in order of importance, with number 1 the most important.)
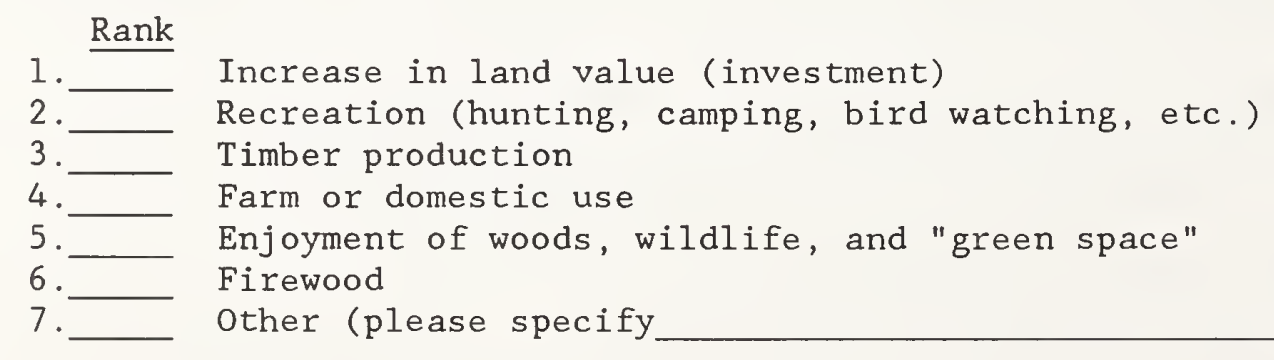
The following questions are asked to insure proper classification to questions 1 through 15 by categories such as age, occupation, and income. Please $\overline{\text { be as }}$ accurate as possible. If you need space to expand on any of your answers, use the space at the end of the questionnaire. Again, answers are strictly confidential and only statistical tabulations are published. No information that could identify you as an individual is ever published.

THESE QUESTIONS DO NOT PERTAIN TO AND SHOULD NOT BE ANSWERED BY CORPORATIONS AND ORGANIZATIONS.

If the woodland is owned by more than one person, the following questions should be answered for the person to whom the questionnaire is addressed. If the questionnaire is addressed to joint owners, as husband and wife, these questions should be answered by the person who makes most of the decisions.

16. What is the age of the owner? Check one

$\begin{array}{ll}\begin{array}{l}1 . \\ 2 .\end{array} & \text { Under } 25 \\ 3 . & 25-34 \\ 4 . \square & 35-44 \\ 5 . & 45-54 \\ 6 . & 55-64 \\ & 65 \text { and over }\end{array}$

17. What is the primary occupation of the owner?

18. What is your best estimate of the total combined income of all members of the owner's household over 14 years of age during the past 12 months? (Please include NET income from businesses, farming, and rentals, money from jobs, pensions, dividends, interest, social security, unemployment, welfare, and workman's compensation.)

Check one

$\begin{array}{ll}\frac{\text { Less than } \$ 10,000}{3 .} & \begin{array}{l}\$ 20,000 \text { to } \$ 29,999 \\ 5 .\end{array} \\ \begin{array}{l}\$ 40,000 \text { to } \$ 49,999 \\ \text { 9.- }\end{array} & \begin{array}{l}\$ 60,000 \text { to } \$ 74,999 \\ \text { Over } \$ 100,000\end{array}\end{array}$

2 .

4.

6 .

8 .

.

$\overline{1}$
$\$ 10,000$ to $\$ 19,999$
$\$ 30,000$ to $\$ 39,999$
$\$ 50,000$ to $\$ 59,999$
$\$ 75,000$ to $\$ 99,999$

Thank you for taking the time to fill out our questionnaire. Your cooperation is greatly appreciated. Would you like to be sent a copy of the results of this survey? 1 . yes 2 . comments you have in the space below. no Please feel free to write in any

Public reporting burden for this collection of information is estimated to average 15 minutes, including the time for reviewing instructions, searching existing data sources, gathering and maintaining the data needed, and completing and reviewing the collection of information. Send comments regarding this burden estimate or any other aspect of this collection of information including suggestions for reducing this burden, to Department of Agriculture, Clearance Officer, OIRM, Room 404-w, Washington, DC 20250; and to the Office of Management and Budget, Paperwork Reduction Project (OMB\# 0596-0078), Washington, DC 20503. 


\section{Western U.S. Tables}

Table 12. Estimated number of ownership units and acres of forest land, by size class and form of ownership, Western United States, 1993

Table 13. Estimated number of ownership units and acres of forest land, by form of ownership and past harvest experience, Western United States, 1993

Table 14. Estimated number of ownership units and acres of forest land, by incorporated and

unincorporated businesses, Western United States, 1993

Table 15. Estimated number of ownership units and acres of forest land, by occupation class and intention to harvest, Western United States, 1993

Table 16. Estimated number of ownership units and acres of forest land, by age class and past harvest experience, Western United States, 1993

Table 17. Estimated number of ownership units and acres of forest land, by date of acquisition and form of ownership, Western United States, 1993

Table 18. Estimated number of ownership units and acres of forest land, by distance from tracts, Western United States, 1993

Table 19. Estimated number of ownership units and acres of forest land, by primary and secondary reason for owning forest land, Western United States, 1993

Table 20. Estimated number of ownership units and acres of forest land, by benefits expected

in the next 10 years and harvest history, Western United States, 1993

Table 21. Estimated number of ownership units and acres of forest land, by size class and intention to harvest, Western United States, 1993

\section{Plains States Tables}

Table 22. Estimated number of ownership units and acres of forest land, by size class and form of ownership, Plains States, 1993.

Table 23. Estimated number of ownership units and acres of forest land, by form of ownership and past harvest experience, Plains States, 1993

Table 24. Estimated number of ownership units and acres of forest land, by incorporated and unincorporated businesses, Plains States, 1993

Table 25. Estimated number of ownership units and acres of forest land, by occupation class and intention to harvest, Plains States, 1993

Table 26. Estimated number of ownership units and acres of forest land, by age class and past harvest experience, Plains States, 1993

Table 27. Estimated number oí ownership units and acres of forest land, by date of acquisition and form of ownership, Plains States, 1993.

Table 28. Estimated number of ownership units and acres of forest land, by distance from tracts, Plains States, 1993

Table 29. Estimated number of ownership units and acres of forest land, by primary and secondary reason for owning forest land, Plains States, 1993

Table 30. Estimated number of ownership units and acres of forest land, by benefits expected in the next 10 years and harvest history, Plains States, 1993. 
Table 31. Estimated number of ownership units and acres of forest land, by size class and intention to harvest, Plains States, 1993

Table 32. Estimated number of ownership units and acres of forest land, by size class and form of ownership, Kansas, 1993

Table 33. Estimated number of ownership units and acres of forest land, by form of ownership and past harvest experience, Kansas, 1993

Table 34. Estimated number of ownership units and acres of forest land, by incorporated and unincorporated businesses, Kansas, 1993

Table 35. Estimated number of ownership units and acres of forest land, by occupation class and intention to harvest, Kansas, 1993

Table 36. Estimated number of ownership units and acres of forest land, by age class and past harvest experience, Kansas, 1993

Table 37. Estimated number of ownership units and acres of forest land, by date of acquisition and form of ownership, Kansas, 1993

Table 38. Estimated number of ownership units and acres of forest land, by distance from tracts, Kansas, 1993

Table 39. Estimated number of ownership units and acres of forest land, by primary and secondary reason for owning forest land, Kansas, 1993

Table 40. Estimated number of ownership units and acres of forest land, by benefits expected in the next 10 years and harvest history, Kansas, 1993.

Table 41. Estimated number of ownership units and acres of forest land, by size class and intention to harvest, Kansas, 1993

Table 42. Estimated number of ownership units and acres of forest land, by size class and form of ownership, Nebraska, 1993

Table 43. Estimated number of ownership units and acres of forest land, by form of ownership and past harvest experience, Nebraska, 1993

Table 44. Estimated number of ownership units and acres of forest land, by incorporated and unincorporated businesses, Nebraska, 1993

Table 45. Estimated number of ownership units and acres of forest land, by occupation class and intention to harvest, Nebraska, 1993

Table 46. Estimated number of ownership units and acres of forest land, by age class and past harvest experience, Nebraska, 1993

Table 47. Estimated number of ownership units and acres of forest land, by date of acquisition and form of ownership, Nebraska, 1993

Table 48. Estimated number of ownership units and acres of forest land by distance from tracts, Nebraska, 1993

Table 49. Estimated number of ownership units and acres of forest land, by primary and secondary reason for owning forest land, Nebraska, 1993.

Table 50. Estimated number of ownership units and acres of forest land, by benefits expected in the next 10 years and harvest history, Nebraska, 1993. 
Table 51. Estimated number of ownership units and acres of forest land, by size class and intention to harvest, Nebraska, 1993.

Table 52. Estimated number of ownership units and acres of forest land, by size class and form of ownership, North Dakota, 1993

Table 53. Estimated number of ownership units and acres of forest land, by form of ownership and past harvest experience, North Dakota, 1993

Table 54. Estimated number of ownership units and acres of forest land, by incorporated and unincorporated businesses, North Dakota, 1993

Table 55. Estimated number of ownership units and acres of forest land, by occupation class and intention to harvest, North Dakota, 1993

Table 56. Estimated number of ownership units and acres of forest land, by age class and past harvest experience, North Dakota, 1993

Table 57. Estimated number of ownership units and acres of forest land, by date of acquisition and form of ownership, North Dakota, 1993

Table 58. Estimated number of ownership units and acres of forest land, by distance from tracts, North Dakota, 1993

Table 59. Estimated number of ownership units and acres of forest land, by primary and secondary reason for owning forest land, North Dakota, 1993.

Table 60. Estimated number of ownership units and acres of forest land, by benefits expected in the next 10 years and harvest history, North Dakota, 1993

Table 61. Estimated number of ownership units and acres of forest land, by size class and intention to harvest, North Dakota, 1993

Table 62. Estimated number of ownership units and acres of forest land, by size class and form of ownership, South Dakota, 1993.

Table 63. Estimated number of ownership units and acres of forest land, by form of ownership and past harvest experience, South Dakota, 1993

Table 64. Estimated number of ownership units and acres of forest land, by incorporated and unincorporated businesses, South Dakota, 1993.

Table 65. Estimated number of ownership units and acres of forest land, by occupation class and intention to harvest, South Dakota, 1993

Table 66. Estimated number of ownership units and acres of forest land, by age class and past harvest experience, South Dakota, 1993

Table 67. Estimated number of ownership units and acres of forest land, by date of acquisition and form of ownership, South Dakota, 1993.

Table 68. Estimated number of ownership units and acres of forest land by distance from tracts, South Dakota, 1993

Table 69. Estimated number of ownership units and acres of forest land, by primary and secondary reason for owning forest land, South Dakota, 1993

Table 70. Estimated number of ownership units and acres of forest land, by benefits expected in the next 10 years and harvest history, South Dakota, 1993 
Table 71. Estimated number of ownership units and acres of forest land, by size class and intention to harvest, South Dakota, 1993

\section{Rocky Mountain States Tables}

Table 72. Estimated number of ownership units and acres of forest land, by size class and form of ownership, Rocky Mountain States, 1993

Table 73. Estimated number of ownership units and acres of forest land, by form of ownership and past harvest experience, Rocky Mountain States, 1993

Table 74. Estimated number of ownership units and acres of forest land, by incorporated and unincorporated businesses, Rocky Mountain States, 1993

Table 75. Estimated number of ownership units and acres of forest land, by occupation class and intention to harvest, Rocky Mountain States, 1993

Table 76. Estimated number of ownership units and acres of forest land, by age class and past harvest experience, Rocky Mountain States, 1993

Table 77. Estimated number of ownership units and acres of forest land, by date of acquisition and form of ownership, Rocky Mountain States, 1993

Table 78. Estimated number of ownership units and acres of forest land, by distance from tracts, Rocky Mountain States, 1993.

Table 79. Estimated number of ownership units and acres of forest land, by primary and secondary reason for owning forest land, Rocky Mountain States, 1993

Table 80. Estimated number of ownership units and acres of forest land, by benefits expected in the next 10 years and harvest history, Rocky Mountain States, 1993

Table 81. Estimated number of ownership units and acres of forest land, by size class and intention to harvest, Rocky Mountain States, 1993

Table 82. Estimated number of ownership units and acres of forest land, by size class and form of ownership, Arizona, 1993

Table 83. Estimated number of ownership units and acres of forest land, by form of ownership and past harvest experience, Arizona, 1993

Table 84. Estimated number of ownership units and acres of forest land, by incorporated and unincorporated businesses, Arizona, 1993.

Table 85. Estimated number of ownership units and acres of forest land, by occupation class and intention to harvest, Arizona, 1993

Table 86. Estimated number of ownership units and acres of forest land, by age class and past harvest experience, Arizona, 1993

Table 87. Estimated number of ownership units and acres of forest land, by date of acquisition and form of ownership, Arizona, 1993

Table 88. Estimated number of ownership units and acres of forest land, by distance from tracts, Arizona, 1993

Table 89. Estimated number of ownership units and acres of forest land, by primary and secondary reason for owning forest land, Arizona, 1993 
Table 90. Estimated number of ownership units and acres of forest land, by benefits expected in the next 10 years and harvest history, Arizona, 1993

Table 91. Estimated number of ownership units and acres of forest land, by size class and intention to harvest, Arizona, 1993

Table 92. Estimated number of ownership units and acres of forest land, by size class and form of ownership, Colorado, 1993

Table 93. Estimated number of ownership units and acres of forest land, by form of ownership and past harvest experience, Colorado, 1993.

Table 94. Estimated number of ownership units and acres of forest land, by incorporated and unincorporated businesses, Colorado, 1993

Table 95. Estimated number of ownership units and acres of forest land, by occupation class and intention to harvest, Colorado, 1993

Table 96. Estimated number of ownership units and acres of forest land, by age class and past harvest experience, Colorado, 1993

Table 97. Estimated number of ownership units and acres of forest land, by date of acquisition and form of ownership, Colorado, 1993

Table 98. Estimated number of ownership units and acres of forest land, by distance from tracts, Colorado, 1993

Table 99. Estimated number of ownership units and acres of forest land, by primary and secondary reason for owning forest land, Colorado, 1993

Table 100. Estimated number of ownership units and acres of forest land, by benefits expected in the next 10 years and harvest history, Colorado, 1993

Table 101. Estimated number of ownership units and acres of forest land, by size class and intention to harvest, Colorado, 1993

Table 102. Estimated number of ownership units and acres of forest land, by size class and form of ownership, Idaho, 1993.

Table 103. Estimated number of ownership units and acres of forest land, by form of ownership and past harvest experience, Idaho, 1993

Table 104. Estimated number of ownership units and acres of forest land, by incorporated and unincorporated businesses, Idaho, 1993

Table 105. Estimated number of ownership units and acres of forest land, by occupation class and intention to harvest, Idaho, 1993

Table 106. Estimated number of ownership units and acres of forest land, by age class and past harvest experience, Idaho, 1993

Table 107. Estimated number of ownership units and acres of forest land, by date of acquisition and form of ownership, Idaho, 1993

Table 108. Estimated number of ownership units and acres of forest land, by distance from tracts, Idaho, 1993

Table 109. Estimated number of ownership units and acres of forest land, by primary and secondary reason for owning forest land, Idaho, 1993 
Table 110. Estimated number of ownership units and acres of forest land, by benefits expected in the next 10 years and harvest history, Idaho, 1993.

Table 111. Estimated number of ownership units and acres of forest land, by size class and intention to harvest, Idaho, 1993

Table 112. Estimated number of ownership units and acres of forest land, by size class and form of ownership, Montana, 1993

Table 113. Estimated number of ownership units and acres of forest land, by form of ownership and past harvest experience, Montana, 1993

Table 114. Estimated number of ownership units and acres of forest land, by incorporated and unincorporated businesses, Montana, 1993

Table 115. Estimated number of ownership units and acres of forest land, by occupation class and intention to harvest, Montana, 1993

Table 116. Estimated number of ownership units and acres of forest land, by age class and past harvest experience, Montana, 1993

Table 117. Estimated number of ownership units and acres of forest land, by date of acquisition and form of ownership, Montana, 1993

Table 118. Estimated number of ownership units and acres of forest land, by distance from tracts, Montana, 1993

Table 119. Estimated number of ownership units and acres of forest land, by primary and secondary reason for owning forest land, Montana, 1993

Table 120. Estimated number of ownership units and acres of forest land, by benefits expected in the next 10 years and harvest history, Montana, 1993

Table 121. Estimated number of ownership units and acres of forest land, by size class and intention to harvest, Montana, 1993

Table 122. Estimated number of ownership units and acres of forest land, by size class and form of ownership, Nevada 1993

Table 123. Estimated number of ownership units and acres of forest land, by form of ownership and past harvest experience, Nevada 1993

Table 124. Estimated number of ownership units and acres of forest land, by incorporated and unincorporated businesses, Nevada 1993

Table 125. Estimated number of ownership units and acres of forest land, by occupation class and intention to harvest, Nevada 1993.

Table 126. Estimated number of ownership units and acres of forest land, by age class and past harvest experience, Nevada 1993

Table 127. Estimated number of ownership units and acres of forest land, by date of acquisition and form of ownership, Nevada 1993

Table 128. Estimated number of ownership units and acres of forest land, by distance from tracts, Nevada 1993

Table 129. Estimated number of ownership units and acres of forest land, by primary and secondary reason for owning forest land, Nevada 1993 
Table 130. Estimated number of ownership units and acres of forest land, by benefits expected in the next 10 years and harvest history, Nevada 1993

Table 131. Estimated number of ownership units and acres of forest land, by size class and intention to harvest, Nevada 1993

Table 132. Estimated number of ownership units and acres of forest land, by size class and form of ownership, New Mexico, 1993

Table 133. Estimated number of ownership units and acres of forest land, by form of ownership and past harvest experience, New Mexico, 1993

Table 134. Estimated number of ownership units and acres of forest land, by incorporated and unincorporated businesses, New Mexico, 1993 160

Table 135. Estimated number of ownership units and acres of forest land, by occupation class and intention to harvest, New Mexico, 1993.

Table 136. Estimated number of ownership units and acres of forest land, by age class and past harvest experience, New Mexico, 1993.

Table 137. Estimated number of ownership units and acres of forest land, by date of acquisition and form of ownership, New Mexico, 1993 163

Table 138. Estimated number of ownership units and acres of forest land, by distance from tracts, New Mexico, 1993

Table 139. Estimated number of ownership units and acres of forest land, by primary and secondary reason for owning forest land, New Mexico, 1993 165

Table 140. Estimated number of ownership units and acres of forest land, by benefits expected in the next 10 years and harvest history, New Mexico, 1993 166

Table 141. Estimated number of ownership units and acres of forest land, by size class and intention to harvest, New Mexico, 1993.

Table 142. Estimated number of ownership units and acres of forest land, by size class and form of ownership, Utah, 1993 168

Table 143. Estimated number of ownership units and acres of forest land, by form of ownership and past harvest experience, Utah, 1993

Table 144. Estimated number of ownership units and acres of forest land, by incorporated and unincorporated businesses, Utah, 1993

Table 145. Estimated number of ownership units and acres of forest land, by occupation class and intention to harvest, Utah, 1993.

Table 146. Estimated number of ownership units and acres of forest land, by age class and past harvest experience, Utah, 1993.

Table 147. Estimated number of ownership units and acres of forest land, by date of acquisition and form of ownership, Utah, 1993

Table 148. Estimated number of ownership units and acres of forest land, by distance from tracts, Utah, 1993.

Table 149. Estimated number of ownership units and acres of forest land, by primary and secondary reason for owning forest land, Utah, 1993 
Table 150. Estimated number of ownership units and acres of forest land, by benefits expected in the next 10 years and harvest history, Utah, 1993

Table 151. Estimated number of ownership units and acres of forest land, by size class and intention to harvest, Utah, 1993

Table 152. Estimated number of ownership units and acres of forest land, by size class and form of ownership, Wyoming, 1993

Table 153. Estimated number of ownership units and acres of forest land, by form of ownership and past harvest experience, Wyoming, 1993

Table 154. Estimated number of ownership units and acres of forest land, by incorporated and unincorporated businesses, Wyoming, 1993

Table 155. Estimated number of ownership units and acres of forest land, by occupation class and intention to harvest, Wyoming, 1993

Table 156. Estimated number of ownership units and acres of forest land, by age class and past harvest experience, Wyoming, 1993

Table 157. Estimated number of ownership units and acres of forest land, by date of acquisition and form of ownership, Wyoming, 1993

Table 158. Estimated number of ownership units and acres of forest land, by distance from tracts, Wyoming, 1993

Table 159. Estimated number of ownership units and acres of forest land, by primary and secondary reason for owning fores! land, Wyoming, 1993

Table 160. Estimated number of ownership units and acres of forest land, by benefits expected in the next 10 years and harvest history, Wyoming, 1993

Table 161. Estimated number of ownership units and acres of forest land, by size class and intention to harvest, Wyoming, 1993

\section{Pacific Coast States Tables}

Table 162. Estimated number of ownership units and acres of forest land, by size class and form of ownership, Pacific Coast States, 1993

Table 163. Estimated number of ownership units and acres of forest land, by form of ownership and past harvest experience, Pacific Coast States, 1993

Table 164. Estimated number of ownership units and acres of forest land, by incorporated and unincorporated businesses, Pacific Coast States, 1993

Table 165. Estimated number of ownership units and acres of forest land, by occupation class and intention to harvest, Pacific Coast States, 1993

Table 166. Estimated number of ownership units and acres of forest land, by age class and past harvest experience, Pacific Coast States, 1993

Table 167. Estimated number of ownership units and acres of forest land, by date of acquisition and form of ownership, Pacific Coast States, 1993

Table 168. Estimated number of ownership units and acres of forest land, by distance from tracts, Pacific Coast States, 1993

Table 169. Estimated number of ownership units and acres of forest land, by primary and secondary reason for owning forest land, Pacific Coast States, 1993 
Table 170. Estimated number of ownership units and acres of forest land, by benefits expected in the next 10 years and harvest history, Pacific Coast States, 1993

Table 171. Estimated number of ownership units and acres of forest land, by size class and intention to harvest, Pacific Coast States, 1993

Table 172. Estimated number of ownership units and acres of forest land, by size class and form of ownership, Alaska, 1993

Table 173. Estimated number of ownership units and acres of forest land, by form of ownership and past harvest experience, Alaska, 1993

Table 174. Estimated number of ownership units and acres of forest land, by incorporated and unincorporated businesses, Alaska, 1993

Table 175. Estimated number of ownership units and acres of forest land, by occupation class and intention to harvest, Alaska, 1993.

Table 176. Estimated number of ownership units and acres of forest land, by age class and past harvest experience, Alaska, 1993

Table 177. Estimated number of ownership units and acres of forest land, by date of acquisition and form of ownership, Alaska, 1993.

Table 178. Estimated number of ownership units and acres of forest land, by distance from tracts, Alaska, 1993

Table 179. Estimated number of ownership units and acres of forest land, by primary and secondary reason for owning forest land, Alaska, 1993

Table 180. Estimated number of ownership units and acres of forest land, by benefits expected in the next 10 years and harvest history, Alaska, 1993

Table 181. Estimated number of ownership units and acres of forest land, by size class and intention to harvest, Alaska, 1993

Table 182. Estimated number of ownership units and acres of forest land, by size class and form of ownership, California, 1993

Table 183. Estimated number of ownership units and acres of forest land, by form of ownership and past harvest experience, California, 1993

Table 184. Estimated number of ownership units and acres of forest land, by incorporated and unincorporated businesses, California, 1993

Table 185. Estimated number of ownership units and acres of forest land, by occupation class and intention to harvest, California, 1993

Table 186. Estimated number of ownership units and acres of forest land, by age class and past harvest experience, California, 1993

Table 187. Estimated number of ownership units and acres of forest land, by date of acquisition and form of ownership, California, 1993

Table 188. Estimated number of ownership units and acres of forest land, by distance from tracts, California, 1993

Table 189. Estimated number of ownership units and acres of forest land, by primary and secondary reason for owning forest land, California, 1993 
Table 190. Estimated number of ownership units and acres of forest land, by benefits expected in the next 10 years and harvest history, California, 1993

Table 191. Estimated number of ownership units and acres of forest land, by size class and intention to harvest, California, 1993

Table 192. Estimated number of ownership units and acres of forest land, by size class and form of ownership, Hawaii, 1993

Table 193. Estimated number of ownership units and acres of forest land, by form of ownership and past harvest experience, Hawaii, 1993

Table 194. Estimated number of ownership units and acres of forest land, by incorporated and unincorporated businesses, Hawaii, 1993

Table 195. Estimated number of ownership units and acres of forest land, by occupation class and intention to harvest, Hawaii, 1993

Table 196. Estimated number of ownership units and acres of forest land, by age class and past harvest experience, Hawaii, 1993

Table 197. Estimated number of ownership units and acres of forest land, by date of acquisition and form of ownership, Hawaii, 1993

Table 198. Estimated number of ownership units and acres of forest land, by distance from tracts, Hawaii, 1993

Table 199. Estimated number of ownership units and acres of forest land, by primary and secondary reason for owning forest land, Hawaii, 1993.

Table 200. Estimated number of ownership units and acres of forest land, by benefits expected in the next 10 years and harvest history, Hawaii, 1993

Table 201. Estimated number of ownership units and acres of forest land, by size class and intention to harvest, Hawaii, 1993

Table 202. Estimated number of ownership units and acres of forest land, by size class and form of ownership, Oregon, 1993.

Table 203. Estimated number of ownership units and acres of forest land, by form of ownership and past harvest experience, Oregon, 1993

Table 204. Estimated number of ownership units and acres of forest land, by incorporated and unincorporated businesses, Oregon, 1993

Table 205. Estimated number of ownership units and acres of forest land, by occupation class and intention to harvest, Oregon, 1993

Table 206. Estimated number of ownership units and acres of forest land, by age class and past harvest experience, Oregon, 1993

Table 207. Estimated number of ownership units and acres of forest land, by date of acquisition and form of ownership, Oregon, 1993

Table 208. Estimated number of ownership units and acres of forest land, by distance from tracts, Oregon, 1993

Table 209. Estimated number of ownership units and acres of forest land by primary and secondary reason for owning forest land, Oregon, 1993 
Table 210. Estimated number of ownership units and acres of forest land, by benefits expected in the next 10 years and harvest history, Oregon, 1993

Table 211. Estimated number of ownership units and acres of forest land, by size class and intention to harvest, Oregon, 1993.

Table 212. Estimated number of ownership units and acres of forest land, by size class and form of ownership, Washington, 1993

Table 213. Estimated number of ownership units and acres of forest land, by form of ownership and past harvest experience, Washington, 1993

Table 214. Estimated number of ownership units and acres of forest land, by incorporated and unincorporated businesses, Washington, 1993

Table 215. Estimated number of ownership units and acres of forest land, by occupation class and intention to harvest, Washington, 1993

Table 216. Estimated number of ownership units and acres of forest land, by age class and past harvest experience, Washington, 1993

Table 217. Estimated number of ownership units and acres of forest land, by date of acquisition and form of ownership, Washington, 1993

Table 218. Estimated number of ownership units and acres of forest land, by distance from tracts, Washington, 1993

Table 219. Estimated number of ownership units and acres of forest land, by primary and secondary reason for owning forest land, Washington, 1993

Table 220. Estimated number of ownership units and acres of forest land, by benefits expected in the next 10 years and harvest history, Washington, 1993

Table 221. Estimated number of ownership units and acres of forest land, by size class and intention to harvest, Washington, 1993 

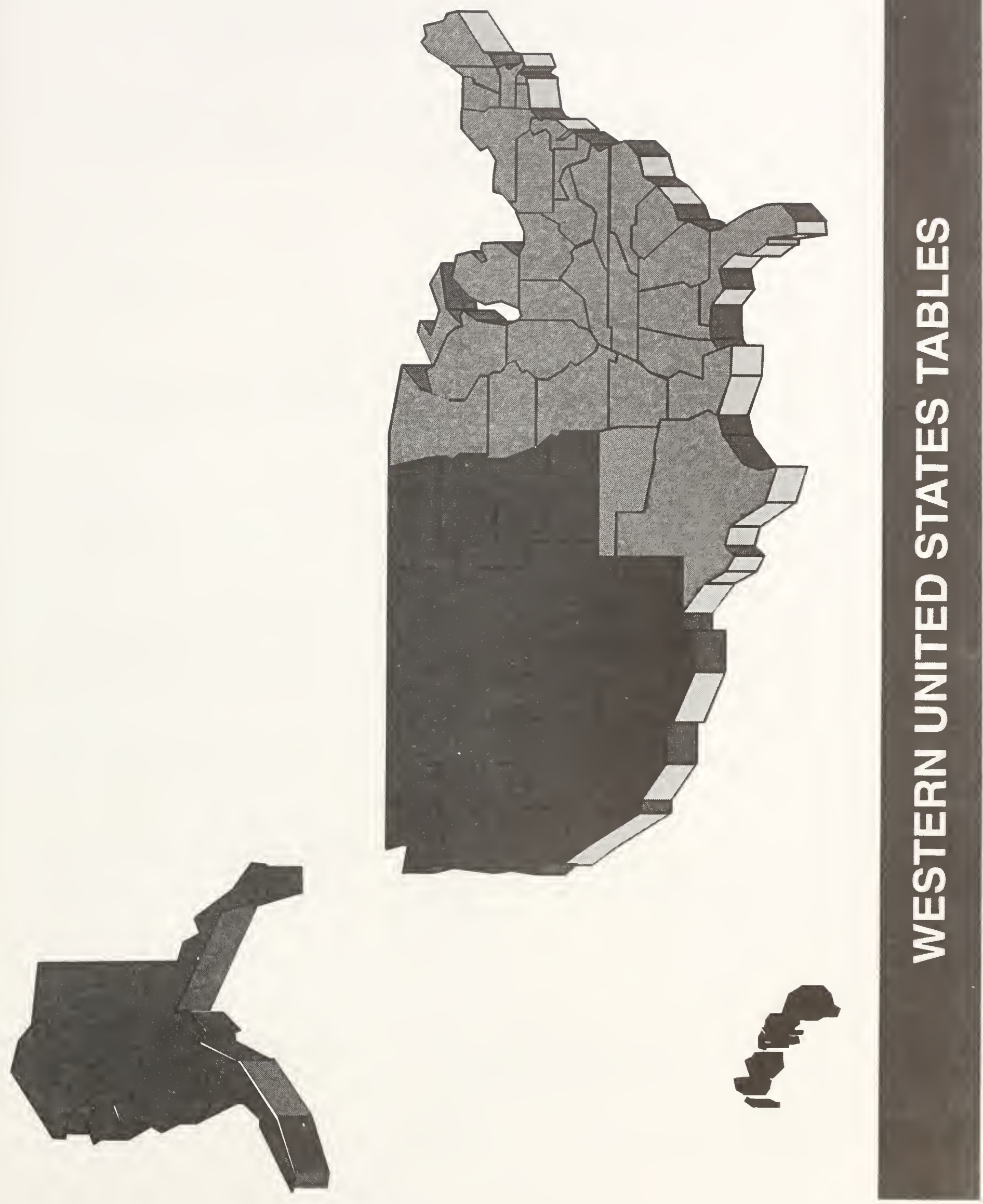


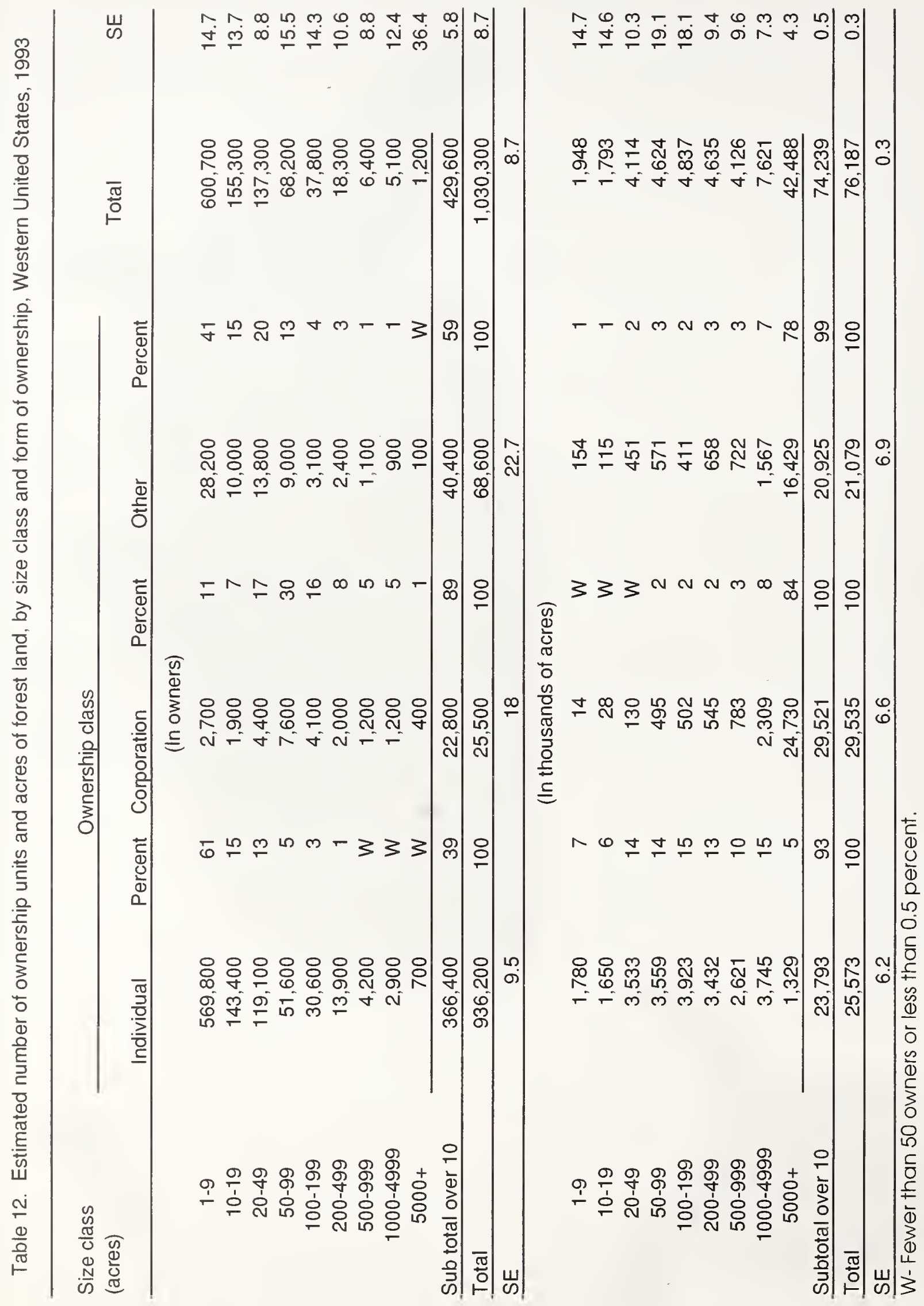


Table 13. Estimated number of ownership units and acres of forest land, by form of ownership and past harvest experiencs. Western United States, 1993

Form of ownership

Harvest experience

Total

Harvested Percent Did not harvest Percent

(In owners)

\begin{tabular}{|c|c|c|c|c|c|c|}
\hline Individual + joint & 400,200 & 91 & 536,000 & 91 & 936,200 & 9.5 \\
\hline Partnership & 16,500 & 4 & 22,100 & 4 & 38,600 & 20.1 \\
\hline Corporation & 9,200 & 2 & 16,300 & 3 & 25,500 & 17.9 \\
\hline Club/association & 800 & W & 11,000 & 2 & 11,800 & 83.1 \\
\hline Other & 12,800 & 3 & 5,400 & 1 & 18,200 & 51.9 \\
\hline Total & 439,400 & 100 & 590,900 & 100 & $1,030,300$ & 8.7 \\
\hline SE & 12.3 & & 12.5 & & 8.7 & \\
\hline \multicolumn{7}{|c|}{ (In thousands of acres) } \\
\hline Individual + joint & 16,997 & 27 & 8,576 & 64 & 25,573 & 6.2 \\
\hline Partnership & 4,583 & 7 & 1,431 & 11 & 6,015 & 11.8 \\
\hline Corporation & 26,897 & 43 & 2,638 & 20 & 29,535 & 6.6 \\
\hline Club/association & 113 & W & 95 & 1 & 208 & 37 \\
\hline Other & 14,268 & 23 & 588 & 4 & 14,856 & 9.4 \\
\hline Total & 62,859 & 100 & 13,329 & 100 & 76,187 & 0.3 \\
\hline SE & 1.3 & & 5.9 & & 0.3 & \\
\hline
\end{tabular}

W-Fewer than 50 owners or less than 0.5 percent 
Table 14. Estimated number of ownership units and acres of forest land, by incorporated and unincorporated businesses and past harvest experience, Western United States, 1993

\begin{tabular}{|c|c|c|c|c|c|c|}
\hline \multirow[t]{2}{*}{ Nature of business } & \multicolumn{4}{|c|}{ Harvest } & \multirow{2}{*}{ Total } & \multirow{2}{*}{ SE } \\
\hline & Harvested & Percent & Did not harvest & Percent & & \\
\hline \multicolumn{7}{|c|}{ (In owners) } \\
\hline \multicolumn{7}{|l|}{ Incorporated: } \\
\hline Forest industry & 900 & W & 0 & 0 & 900 & 38 \\
\hline Farm & 3,300 & 1 & 7,300 & 1 & 10,600 & 25.1 \\
\hline Industrial business & 600 & W & 1,600 & W & 2,200 & 43.3 \\
\hline Real estate & 500 & W & 5,500 & 1 & 6,000 & 52.2 \\
\hline Non-industrial & W & W & 0 & 0 & W & 95.7 \\
\hline Sport/ recreation club & 2,500 & 1 & 1,500 & W & 4,000 & 43 \\
\hline Public utility & W & W & 0 & 0 & W & 79.2 \\
\hline Other & 1,400 & W & 400 & W & 1,800 & 37.4 \\
\hline Total corporate & 9,200 & 2 & 16,300 & 3 & 25,500 & 17.9 \\
\hline \multicolumn{7}{|l|}{ Unincorporated: } \\
\hline Forest industry & 100 & W & 0 & 0 & 100 & 32.6 \\
\hline Farm & 115,300 & 26 & 133,100 & 23 & 248,400 & 16.3 \\
\hline Misc. individual & 288,400 & 66 & 406,100 & 69 & 694,500 & 11.6 \\
\hline Industrial business & 300 & W & 3,000 & 1 & 3,300 & 81 \\
\hline Real estate & 2,200 & 1 & 4,800 & 1 & 7,000 & 38.9 \\
\hline Nonindustrial business & 5,000 & 1 & 3,400 & 1 & 8,400 & 50.2 \\
\hline Sport/ recreation club & 6,500 & 1 & 11,800 & 1 & 18,200 & 88 \\
\hline Other & 14,500 & 3 & 13,100 & 3 & 27,600 & 40.8 \\
\hline Total noncorporate & 430,200 & 98 & 574,600 & 97 & $1,004,800$ & 8.9 \\
\hline Total & 439,400 & 100 & 590,900 & 100 & $1,030,300$ & 8.7 \\
\hline SE & 12.3 & & 12.5 & & 8.7 & \\
\hline \multicolumn{7}{|c|}{ (In thousands of acres) } \\
\hline Incorporated: & & & & & & \\
\hline Forest industry & 13,703 & 22 & 0 & 0 & 13,703 & 12.9 \\
\hline Farm & 2,950 & 5 & 1,541 & 11 & 4,491 & 12 \\
\hline Industrial business & 513 & 1 & 351 & 3 & 863 & 37 \\
\hline Real estate & 301 & 1 & 360 & 3 & 662 & 23.9 \\
\hline Non-industrial & 59 & W & 0 & 0 & 59 & 100 \\
\hline Sport/ recreation club & 529 & 1 & 183 & 1 & 712 & 31.3 \\
\hline Public utility & 113 & W & 0 & 0 & 113 & 62 \\
\hline Other & 8,729 & 13 & 203 & 1 & 8,932 & 11.7 \\
\hline Total corporate & 26,897 & 43 & 2,638 & 20 & 29,535 & 6.6 \\
\hline \multicolumn{7}{|l|}{ Unincorporated: } \\
\hline Forest industry & 10,286 & 16 & 0 & 0 & 10,286 & 17.2 \\
\hline Farm & 11,746 & 19 & 4,620 & 35 & 16,366 & 5.2 \\
\hline Misc. individual & 7,077 & 11 & 4,802 & 36 & 11,879 & 10.2 \\
\hline Industrial business & 396 & 1 & 66 & 1 & 462 & 71.2 \\
\hline Real estate & 622 & 1 & 479 & 3 & 1,101 & 22.8 \\
\hline Nonindustrial business & 161 & W & 83 & 1 & 244 & 32.2 \\
\hline Sport/ recreation club & 264 & W & 154 & 1 & 417 & 27 \\
\hline Other & 5,409 & 9 & 487 & 3 & 5,896 & 23.4 \\
\hline Total noncorporate & 35,961 & 57 & 10,691 & 80 & 46,652 & 4.2 \\
\hline Total & 62,859 & 100 & 13,329 & 100 & 76,187 & 0.3 \\
\hline SE & 1.3 & & 5.9 & & 0.3 & \\
\hline
\end{tabular}

W- Fewer than 50 owners or less than 0.5 percent 


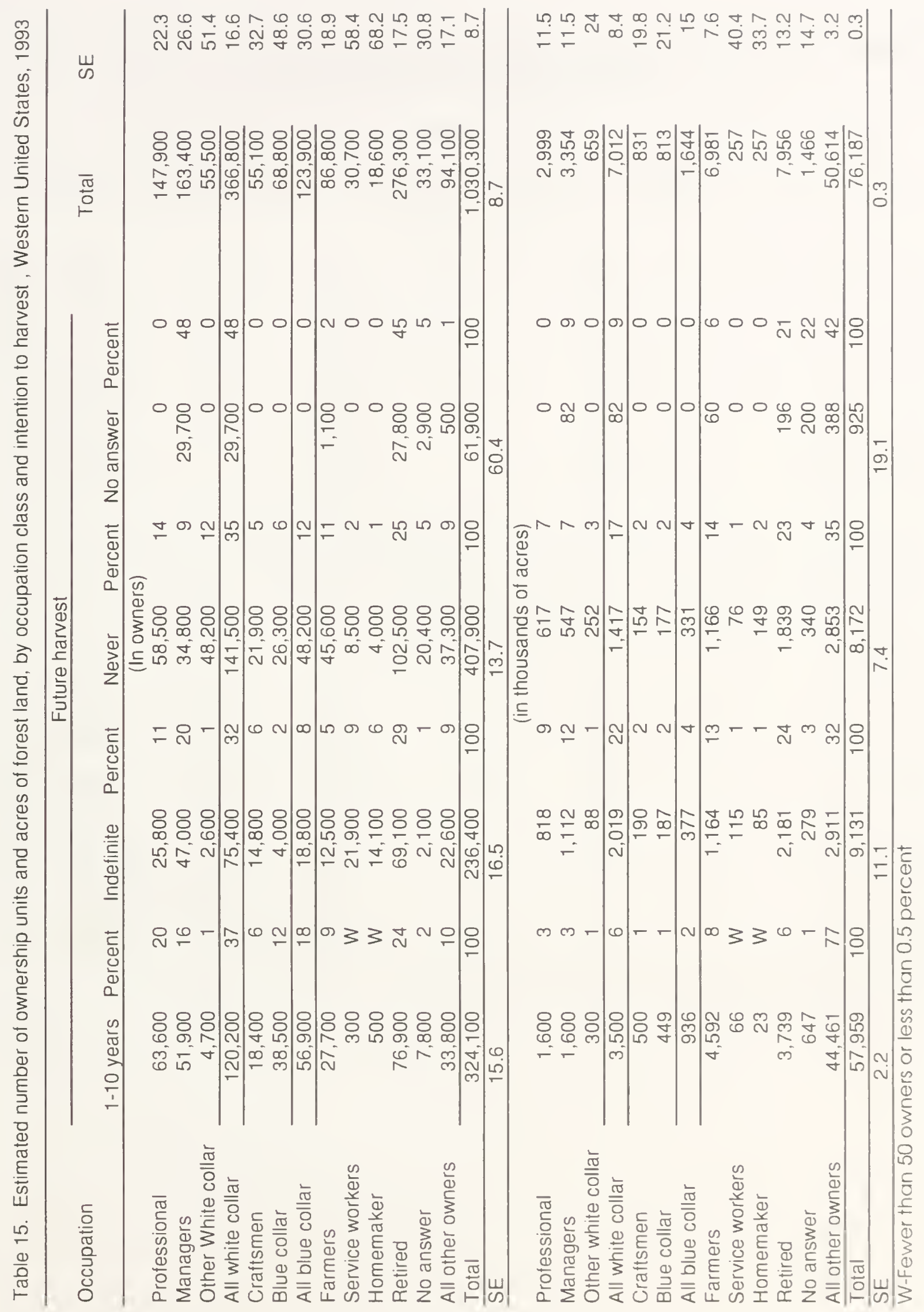


Table 16. Estimated number of ownership units and acres of forest land, by age class and past harvest experience, Western United States, 1993

\begin{tabular}{|c|c|c|c|c|c|c|}
\hline \multirow[t]{2}{*}{ Age } & \multicolumn{4}{|c|}{ Harvest experience } & \multirow{2}{*}{ Total } & \multirow{2}{*}{ SE } \\
\hline & Harvested & Percent & Did not harvest & Percent & & \\
\hline \multicolumn{7}{|c|}{ (In owners) } \\
\hline Under 25 & 900 & W & 0 & 0 & 900 & 75.4 \\
\hline $25-34$ & 5,200 & 1 & 3,900 & 1 & 9,100 & 40.9 \\
\hline $35-44$ & 98,000 & 22 & 99,800 & 17 & 197,800 & 20 \\
\hline $45-54$ & 53,900 & 12 & 163,400 & 28 & 217,300 & 23.6 \\
\hline $55-64$ & 88,600 & 20 & 114,800 & 19 & 203,400 & 20.2 \\
\hline 65 or over & 150,200 & 34 & 143,500 & 24 & 293,700 & 16.8 \\
\hline No answer & 3,400 & 1 & 10,600 & 2 & 14,000 & 55.2 \\
\hline All other owners & 39,200 & 9 & 54,900 & 9 & 94,100 & 17.1 \\
\hline Total & 439,400 & 100 & 590,900 & 100 & $1,030,300$ & 8.7 \\
\hline SE & 12.3 & & 12.5 & & 8.7 & \\
\hline \multicolumn{7}{|c|}{ (In thousands of acres) } \\
\hline Under 25 & 99 & W & 0 & 0 & 99 & 66 \\
\hline $25-34$ & 257 & W & 119 & 1 & 377 & 31.4 \\
\hline $35-44$ & 1,849 & 3 & 1,058 & 8 & 2,907 & 11.9 \\
\hline $45-54$ & 2,446 & 4 & 2,235 & 16 & 4,681 & 9 \\
\hline $55-64$ & 3,465 & 5 & 2,174 & 16 & 5,639 & 8.8 \\
\hline 65 or over & 8,640 & 14 & 2,646 & 20 & 11,286 & 10.1 \\
\hline No answer & 240 & W & 343 & 3 & 583 & 22.5 \\
\hline All other owners & 45,861 & 73 & 4,753 & 36 & 50,614 & 3.2 \\
\hline Total & 62,859 & 100 & 13,329 & 100 & 76,187 & 0.3 \\
\hline SE & 1.3 & & 5.9 & & 0.3 & \\
\hline
\end{tabular}

W-Fewer than 50 owners of less than 0.5 percent 
Table 17. Estimated number of ownership units and acres of forest land, by date of aquisition and form of ownership, Western United States, 1993

\begin{tabular}{|c|c|c|c|c|c|c|c|}
\hline \multirow[b]{2}{*}{$\begin{array}{c}\text { Date of } \\
\text { acquisition }\end{array}$} & \multicolumn{5}{|c|}{ Ownership class } & \multirow[b]{2}{*}{ Total } & \multirow[b]{2}{*}{ SE } \\
\hline & $\begin{array}{c}\text { Forest } \\
\text { industry }\end{array}$ & Farmer & $\begin{array}{l}\text { Miscellaneous: } \\
\text { Individual }\end{array}$ & Corporation & Other & & \\
\hline \multicolumn{8}{|c|}{ (In owners) } \\
\hline $1990-1994$ & W & 11,900 & 150,900 & 4,100 & 7,300 & 174,200 & 24.4 \\
\hline $1980-1989$ & 100 & 36,500 & 203,400 & 3,400 & 17,800 & 261,100 & 18.1 \\
\hline $1970-1979$ & 200 & 53,500 & 204,300 & 2,100 & 12,600 & 272,700 & 17.8 \\
\hline $1960-1969$ & 300 & 31,900 & 58,900 & 2,300 & 7,800 & 101,300 & 20.3 \\
\hline $1950-1959$ & 100 & 44,500 & 38,000 & 600 & 3,600 & 86,800 & 30.5 \\
\hline $1940-1949$ & 100 & 55,400 & 12,300 & 200 & 400 & 68,400 & 36.2 \\
\hline $1901-1939$ & W & 14,500 & 13,400 & 600 & 1,400 & 30,000 & 40.4 \\
\hline Prior to 1900 & 100 & 600 & 1,100 & 300 & 600 & 2,700 & 33.4 \\
\hline No answer & 300 & 10,200 & 21,900 & 200 & 600 & 33,100 & 59.2 \\
\hline Total & 1,100 & 259,000 & 704,100 & 13,900 & 52,200 & $1,030,300$ & 8.7 \\
\hline SE & 33.7 & 15.6 & 11.4 & 26.8 & 28.8 & 8.7 & \\
\hline \multicolumn{8}{|c|}{ (In thousands of acres) } \\
\hline $1990-1994$ & 172 & 1,046 & 1,389 & 434 & 195 & 3,235 & 13.7 \\
\hline $1980-1989$ & 636 & 3,168 & 2,475 & 2,635 & 627 & 9,542 & 14.7 \\
\hline $1970-1979$ & 261 & 3,568 & 3,185 & 6,706 & 310 & 14,031 & 11.5 \\
\hline $1960-1969$ & 446 & 3,559 & 1,457 & 470 & 357 & 6,288 & 8.7 \\
\hline $1950-1959$ & 1,331 & 2,792 & 2,406 & 342 & 179 & 7,050 & 16.2 \\
\hline $1940-1949$ & 1,781 & 2,357 & 707 & 162 & 102 & 5,109 & 14.2 \\
\hline $1901-1939$ & 2,741 & 2,234 & 406 & 277 & 1,136 & 6,794 & 14.9 \\
\hline Prior to 1900 & 16,501 & 1,085 & 104 & 142 & 4.462 & 22,296 & 9.2 \\
\hline No answer & 120 & 1,048 & 325 & 172 & 177 & 1,842 & 16.5 \\
\hline Total & 23.989 & 20,857 & 12,455 & 11,341 & 7,545 & 76,187 & 0.3 \\
\hline SE & 9.2 & 5 & 9.9 & 9.2 & 19.1 & 0.3 & \\
\hline
\end{tabular}

W-fewer than 50 owners or less than 0.5 percent 
Table 18. Estimated number of ownership units and acres of forest land, by distance from tracts, Western United States, 1993

\begin{tabular}{|c|c|c|c|c|}
\hline \multirow{3}{*}{ Distance } & \multicolumn{3}{|c|}{ Tracts } & \multirow{3}{*}{ Total } \\
\hline & \multirow[b]{2}{*}{1 tract } & \multicolumn{2}{|c|}{ More than one tract } & \\
\hline & & Nearest tract & Farthest tract & \\
\hline \multicolumn{5}{|c|}{ (In owners) } \\
\hline Less than 1 mile & 375,300 & 112,900 & 51,100 & \\
\hline 2-5 miles & 59,200 & 11,200 & 26,000 & \\
\hline $6-15$ miles & 33,200 & 10,600 & 20,500 & \\
\hline $16-25$ miles & 19,600 & 4,800 & 4,400 & \\
\hline $26-50$ miles & 32,400 & 8,900 & 17,200 & \\
\hline $51-100$ miles & 36,000 & 5,700 & 8,000 & \\
\hline More than 100 miles & 237,600 & 29,100 & 55,900 & \\
\hline No answer & 49,000 & 4,900 & 4,900 & \\
\hline Total & 842,300 & 188,000 & 188,000 & $1,030,300$ \\
\hline \multicolumn{5}{|c|}{ (In thousands of acres) } \\
\hline Less than 1 mile & 8,493 & 22,794 & 2,562 & \\
\hline 2-5 miles & 1,042 & 5,558 & 2,683 & \\
\hline $6-15$ miles & 1,260 & 6,753 & 4,098 & \\
\hline $16-25$ miles & 522 & 1,147 & 2,795 & \\
\hline $26-50$ miles & 1,382 & 6,613 & 4,763 & \\
\hline $51-100$ miles & 900 & 1,017 & 7,664 & \\
\hline More than 100 miles & 3,592 & 3,255 & 22,554 & \\
\hline No answer & 1,682 & 10,178 & 10,194 & \\
\hline Total & 18,873 & 57,314 & 57,314 & 76,187 \\
\hline
\end{tabular}


Table 19. Estimated number of ownership units and acres of forest land, by primary and secondary reason for owning forest land, Western United States, 1993

\begin{tabular}{|c|c|c|c|c|}
\hline \multirow[t]{2}{*}{ Reason } & \multicolumn{2}{|l|}{ Primary reason } & \multicolumn{2}{|c|}{ Secondary reason } \\
\hline & Number & Percent & Number & Percent \\
\hline & \multicolumn{4}{|c|}{ (In owners) } \\
\hline Land investment & 90,900 & 9 & 18,200 & 2 \\
\hline Recreation & 104,300 & 10 & 80,600 & 8 \\
\hline Timber production & 14,800 & 1 & 24,200 & 2 \\
\hline Farm and domestic use & 57,600 & 6 & 71,800 & 7 \\
\hline Esthetic enjoyment & 199,100 & 19 & 113,200 & 11 \\
\hline Part of farm & 134,200 & 13 & 15,500 & 2 \\
\hline Part of residence & 197,300 & 19 & 111,200 & 11 \\
\hline Estate & 93,300 & 9 & 110,700 & 11 \\
\hline Other & 133,000 & 13 & 32,500 & 3 \\
\hline No secondary reason given & - & - & 446,500 & 43 \\
\hline No answer & 5,700 & 1 & 5,700 & 1 \\
\hline \multirow[t]{2}{*}{ Total } & $1,030,300$ & 100 & $1,030,300$ & 100 \\
\hline & \multicolumn{4}{|c|}{ (In thousands of acres) } \\
\hline Land investment & 3,997 & 5 & 6,391 & 8 \\
\hline Recreation & 5,532 & 7 & 6,127 & 8 \\
\hline Timber production & 23,049 & 30 & 5,095 & 7 \\
\hline Farm and domestic use & 9,802 & 13 & 6,611 & 9 \\
\hline Esthetic enjoyment & 3,644 & 5 & 4,391 & 6 \\
\hline Part of farm & 6,575 & 9 & 1,996 & 3 \\
\hline Part of residence & 4,031 & 5 & 2,592 & 3 \\
\hline Estate & 2,486 & 3 & 5,285 & 7 \\
\hline Other & 15,093 & 20 & 7,331 & 10 \\
\hline No secondary reason given & - & - & 28,388 & 37 \\
\hline No answer & 1,978 & 3 & 1,978 & 3 \\
\hline Total & 76,187 & 100 & 76,187 & 100 \\
\hline
\end{tabular}


Table 20. Estimated number of ownership units and acres of forest land, by primary benefit expected in the next 10 years and past harvest experience, Western United States, 1993

\begin{tabular}{|c|c|c|c|c|c|c|}
\hline \multirow[t]{2}{*}{ Benefits expected } & \multicolumn{4}{|c|}{ Harvest Experience } & \multirow{2}{*}{ Total } & \multirow{2}{*}{ SE } \\
\hline & Harvested & Percent & Did not harvest & Percent & & \\
\hline \multicolumn{7}{|c|}{ (In owners) } \\
\hline Land value increase & 68,500 & 16 & 112,900 & 19 & 181,400 & 22.9 \\
\hline Recreation & 21,100 & 5 & 100,300 & 17 & 121,400 & 34.8 \\
\hline Income from timber & 14,700 & 3 & 6,700 & 1 & 21,400 & 18.8 \\
\hline Farm and domestic use & 69,600 & 16 & 51,900 & 9 & 121,500 & 19.6 \\
\hline Esthetic enjoyment & 176,600 & 40 & 188,700 & 32 & 365,300 & 13.8 \\
\hline Firewood & 26,200 & 6 & 700 & W & 26,900 & 85.5 \\
\hline Other & 48,500 & 11 & 70,500 & 12 & 119,100 & 21.8 \\
\hline No answer & 14,100 & 3 & 59,200 & 10 & 73,300 & 38.1 \\
\hline Total & 439,400 & 100 & 590,900 & 100 & $1,030,300$ & 8.7 \\
\hline SE & 12.3 & & 12.5 & & 8.7 & \\
\hline \multicolumn{7}{|c|}{ (In thousands of acres) } \\
\hline Land value increase & 3,257 & 5 & 2,406 & 18 & 5,663 & 8.7 \\
\hline Recreation & 5,643 & 9 & 1,902 & 14 & 7,545 & 19.4 \\
\hline Income from timber & 24,568 & 39 & 652 & 5 & 25,220 & 8.2 \\
\hline Farm and domestic use & 9,744 & 16 & 1,683 & 13 & 11,427 & 18 \\
\hline Esthetic enjoyment & 5,223 & 8 & 3,453 & 26 & 8,676 & 12 \\
\hline Firewood & 424 & 1 & 56 & W & 480 & 23.5 \\
\hline Other & 11,374 & 18 & 2,115 & 16 & 13,489 & 15.6 \\
\hline No answer & 2,626 & 4 & 1,061 & 8 & 3,687 & 28.6 \\
\hline Total & 62,859 & 100 & 13,329 & 100 & 76,187 & 0.3 \\
\hline SE & 1.3 & & 5.9 & & 0.3 & \\
\hline
\end{tabular}

W-fewer than 50 owners or less than 0.5 percent 


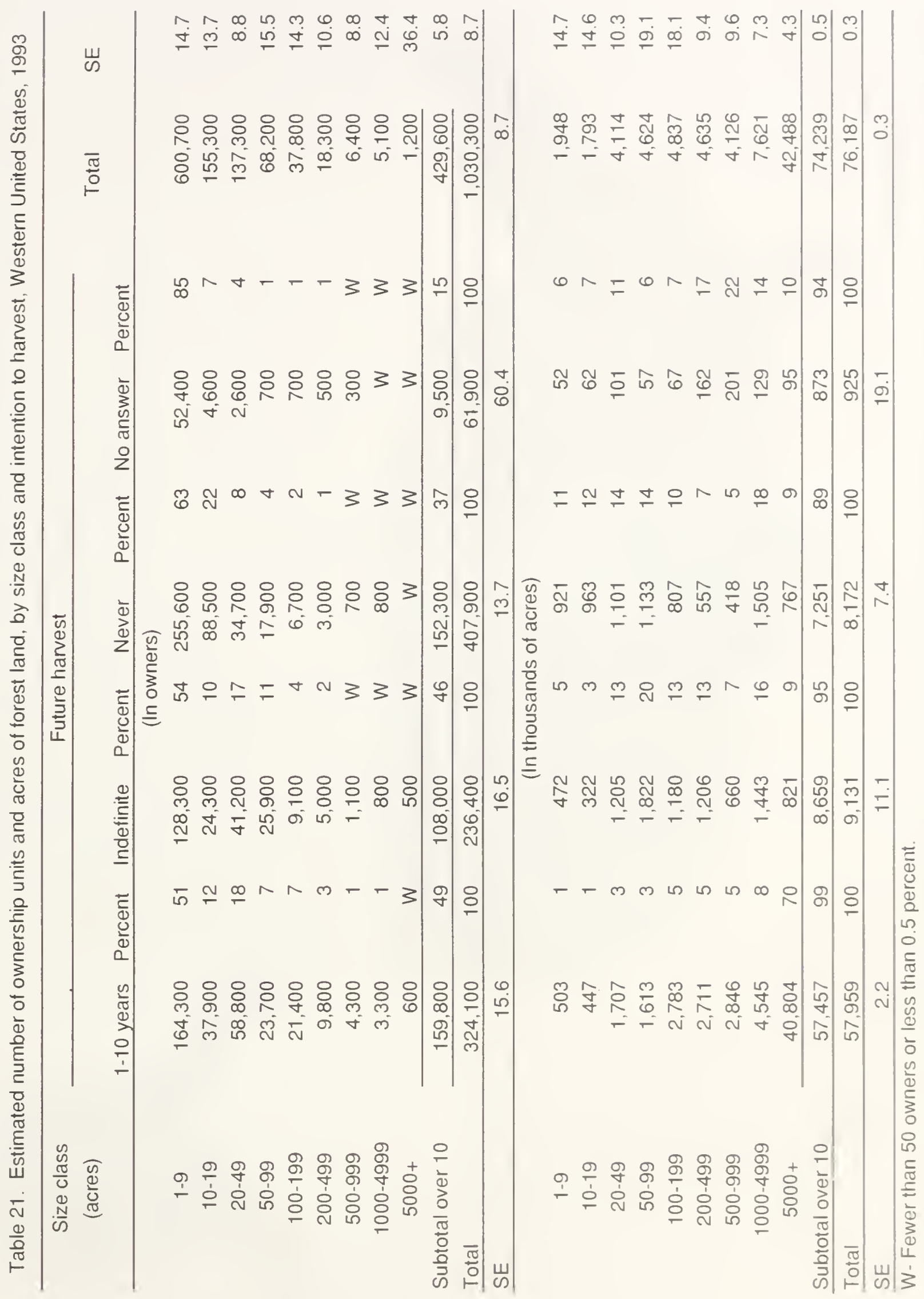




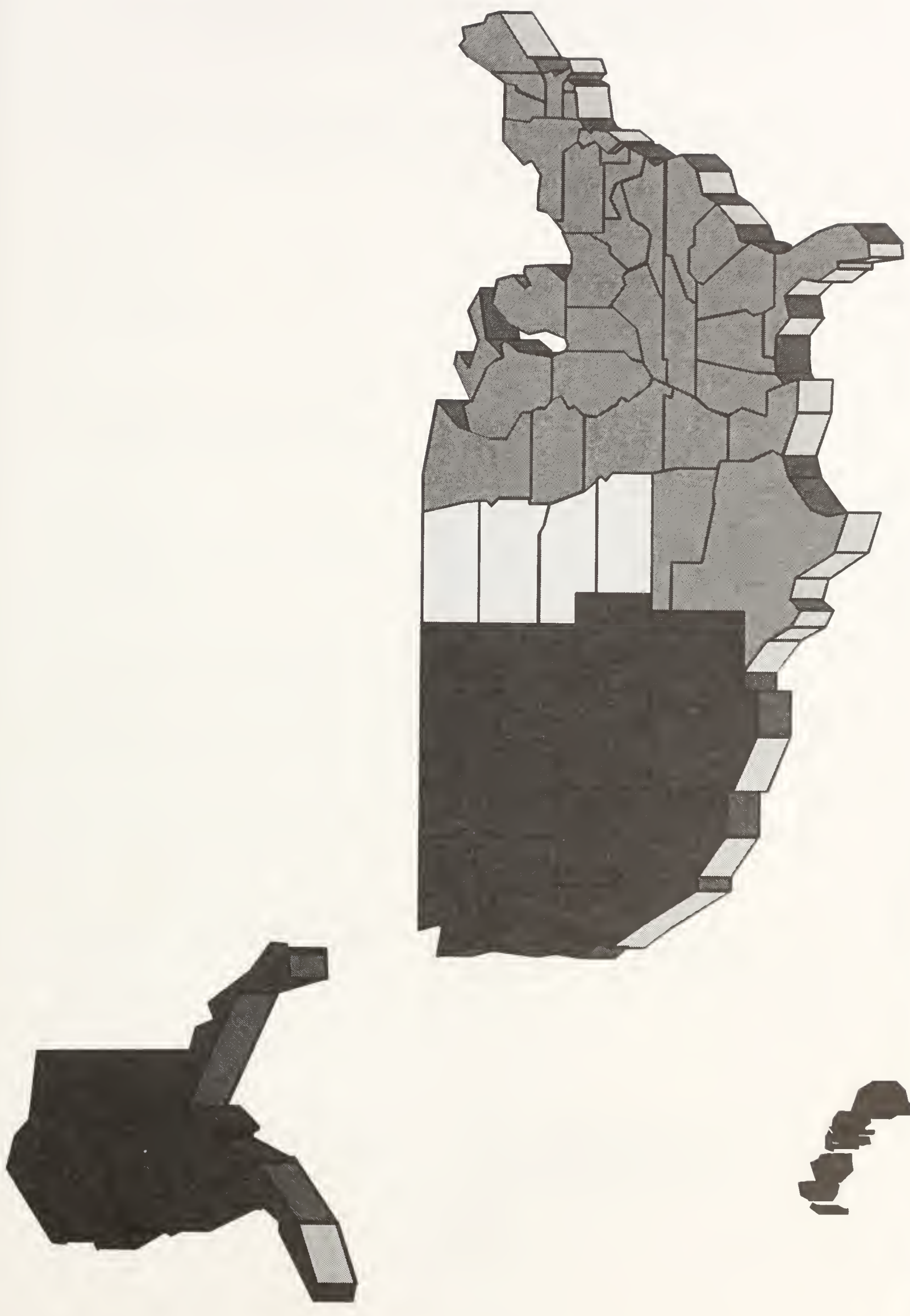

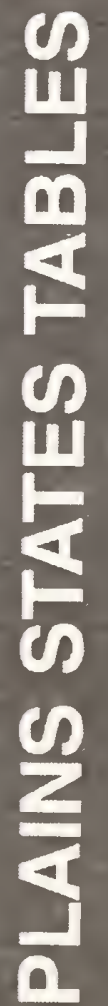




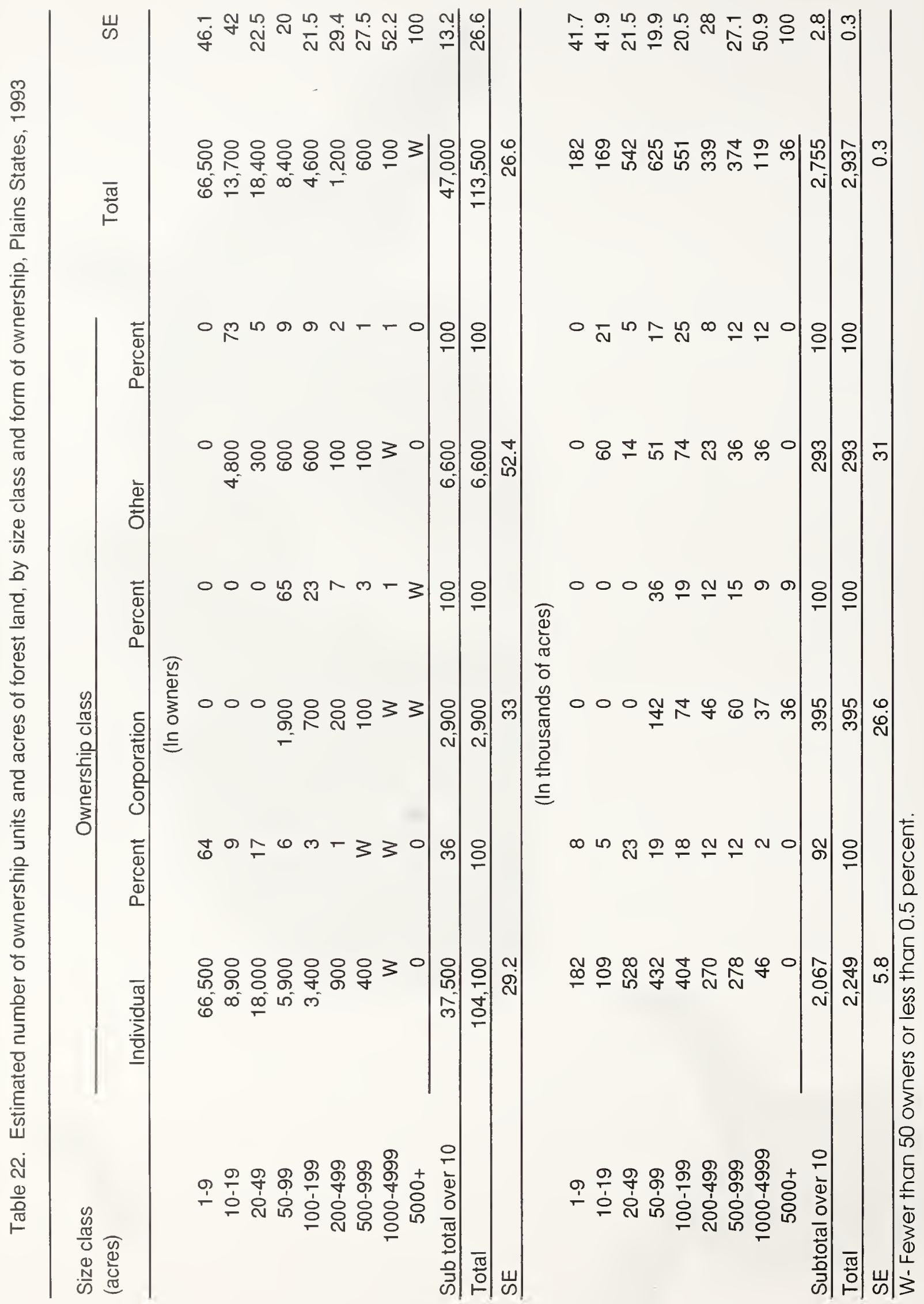


Table 23. Estimated number of ownership units and acres of forest land, by form of ownership and past harvest experience, Plains States, 1993

\begin{tabular}{|c|c|c|c|c|c|c|}
\hline \multirow[t]{2}{*}{ Form of ownership } & \multicolumn{4}{|c|}{ Harvest experience } & \multirow{2}{*}{ Total } & \multirow{2}{*}{ SE } \\
\hline & Harvested & Percent & Did not harvest & Percent & & \\
\hline \multicolumn{7}{|c|}{ (In owners) } \\
\hline Individual + joint & 32,900 & 85 & 71.100 & 95 & 104,100 & 29.2 \\
\hline Partnership & 3.700 & 10 & 2,300 & 3 & 6,000 & 56.6 \\
\hline Corporation & 1,800 & 5 & 1,100 & 1 & 2,900 & 33.2 \\
\hline Club/association & 0 & 0 & 500 & 1 & 500 & 100 \\
\hline Other & 100 & W & 0 & 0 & 100 & 100 \\
\hline Total & 38,500 & 100 & 75,000 & 100 & 113,500 & 26.6 \\
\hline SE & 32.6 & & 37.6 & & 26.6 & \\
\hline \multicolumn{7}{|c|}{ (In thousands of acres) } \\
\hline Individual + joint & 1,446 & 73 & 803 & 83 & 2,249 & 5.8 \\
\hline Partnership & 197 & 10 & 23 & 2 & 220 & 35 \\
\hline Corporation & 289 & 15 & 106 & 11 & 395 & 26.6 \\
\hline Club/association & 0 & 0 & 37 & 4 & 37 & 100 \\
\hline Other & 36 & 2 & 0 & 0 & 36 & 100 \\
\hline Total & 1,967 & 100 & 969 & 100 & 2.937 & 0.3 \\
\hline SE & 7.1 & & 14.5 & & 0.3 & \\
\hline
\end{tabular}

W-Fewer than 50 owners or less than 0.5 percent 
Table 24. Estimated number of ownership units and acres of forest land, by incorporated and unincorporated businesses and past harvest experience, Plains States, 1993

\begin{tabular}{|c|c|c|c|c|c|c|}
\hline \multirow[t]{2}{*}{ Nature of business } & \multicolumn{4}{|c|}{ Harvest } & \multirow{2}{*}{ Total } & \multirow{2}{*}{ SE } \\
\hline & Harvested & Percent & Did not harvest & Percent & & \\
\hline \multicolumn{7}{|c|}{ (In owners) } \\
\hline \multicolumn{7}{|l|}{ Incorporated: } \\
\hline Forest industry & W & W & 0 & 0 & W & 100 \\
\hline Farm & 500 & 1 & 700 & 1 & 1,200 & 46.9 \\
\hline Industrial business & 500 & 1 & 0 & 0 & 500 & 100 \\
\hline Sport/ recreation club & 500 & 1 & 0 & 0 & 500 & 81.4 \\
\hline Other & 300 & 1 & 400 & W & 700 & 71.6 \\
\hline Total corporate & 1,800 & 5 & 1,100 & 2 & 2,900 & 33.2 \\
\hline \multicolumn{7}{|l|}{ Unincorporated: } \\
\hline Farm & 32,400 & 84 & 58,500 & 78 & 91,000 & 31.2 \\
\hline Misc. individual & 4,300 & 11 & 14,900 & 20 & 19,200 & 63.6 \\
\hline Sport/ recreation club & 0 & 0 & 500 & W & 500 & 100 \\
\hline Total noncorporate & 36,700 & 95 & 73,900 & 98 & 110,600 & 27.4 \\
\hline Total & 38,500 & 100 & 75,000 & 100 & 113,500 & 26.6 \\
\hline SE & 32.6 & & 37.6 & & 26.6 & \\
\hline \multicolumn{7}{|c|}{ (In thousands of acres) } \\
\hline Incorporated: & & & & & & \\
\hline Forest industry & 36 & 2 & 0 & 0 & 36 & 100 \\
\hline Farm & 120 & 6 & 83 & 9 & 203 & 37.3 \\
\hline Industrial business & 36 & 2 & 0 & 0 & 36 & 100 \\
\hline Sport/ recreation club & 60 & 3 & 0 & 0 & 60 & 72.5 \\
\hline Other & 37 & 2 & 23 & 2 & 60 & 72.5 \\
\hline Total corporate & 289 & 15 & 106 & 11 & 395 & 26.6 \\
\hline \multicolumn{7}{|l|}{ Unincorporated: } \\
\hline Farm & 1,445 & 73 & 653 & 67 & 2,098 & 6.6 \\
\hline Misc. individual & 234 & 12 & 173 & 18 & 407 & 26 \\
\hline Sport/ recreation club & 0 & 0 & 37 & 4 & 37 & 100 \\
\hline Total noncorporate & 1,679 & 85 & 863 & 89 & 2,542 & 4.1 \\
\hline Total & 1,967 & 100 & 969 & 100 & 2,937 & 0.3 \\
\hline SE & 7.1 & & 14.5 & & 0.3 & \\
\hline
\end{tabular}

W- Fewer than 50 owners or less than 0.5 percent 


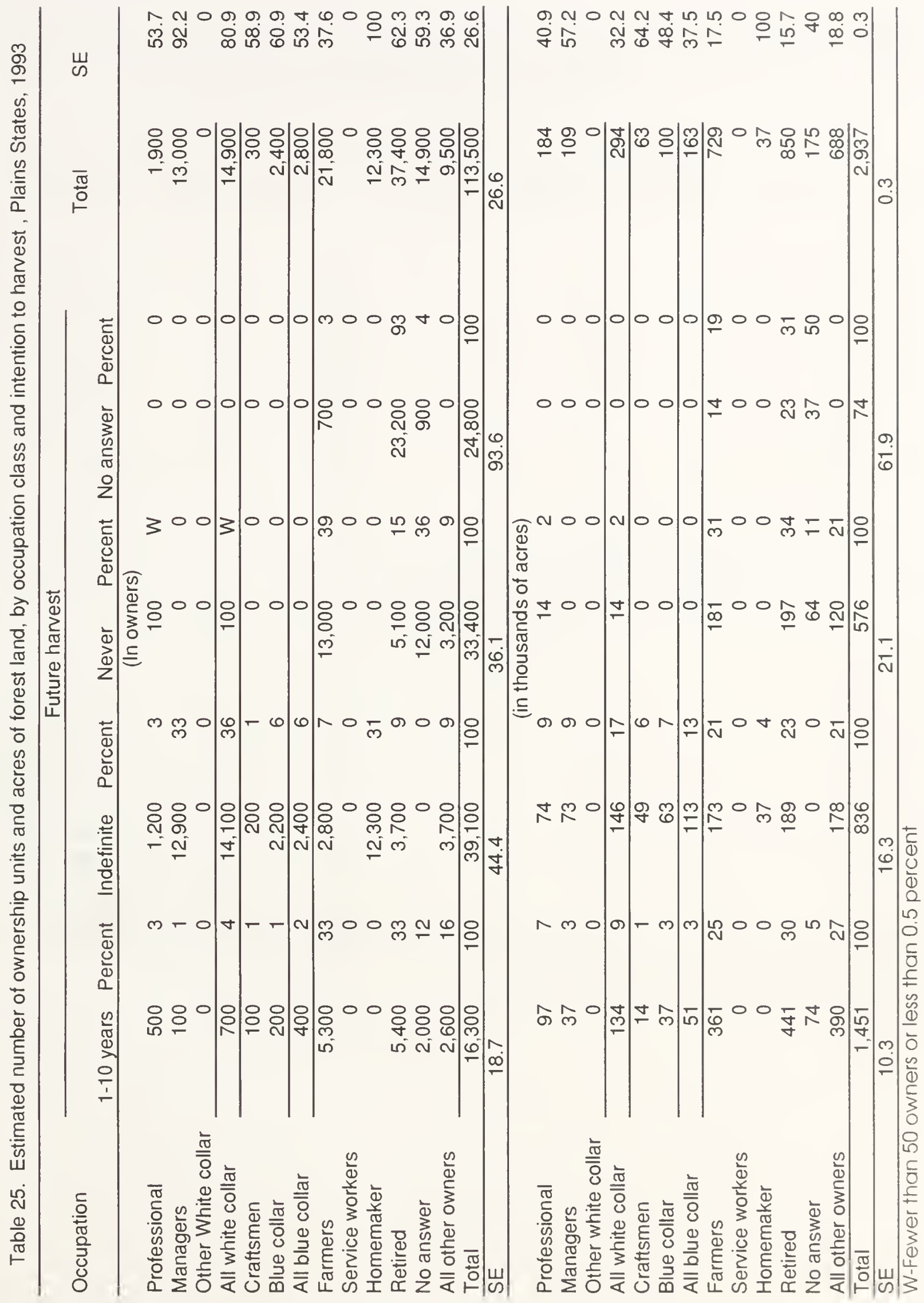


Table 26. Estimated number of ownership units and acres of forest land, by age class and past harvest experience, Plains States, 1993

Age Harvest experience

Harvested Percent Did not harvest Percent

Total

SE (In owners)

\begin{tabular}{|c|c|c|c|c|c|c|}
\hline Under 25 & 0 & 0 & 0 & 0 & 0 & 0 \\
\hline 25-34 & 0 & 0 & 0 & 0 & 0 & 0 \\
\hline $35-44$ & 100 & W & 6,900 & 9 & 7,000 & 69 \\
\hline $45-54$ & 4,500 & 11 & 16,000 & 21 & 20,400 & 60.5 \\
\hline $55-64$ & 1,900 & 5 & 2,600 & 3 & 4,500 & 46.4 \\
\hline 65 or over & 26,500 & 69 & 37,300 & 50 & 63,800 & 42.6 \\
\hline No answer & 0 & 0 & 8,300 & 11 & 8,300 & 89.3 \\
\hline All other owners & 5,600 & 14 & 3,900 & 5 & 9,500 & 36.9 \\
\hline Total & 38,500 & 100 & 75,000 & 100 & 113,500 & 26.6 \\
\hline SE & 32.6 & & 37.6 & & 26.6 & \\
\hline \multicolumn{7}{|c|}{ (In thousands of acres) } \\
\hline Under 25 & 0 & 0 & 0 & 0 & 0 & 0 \\
\hline $25-34$ & 0 & 0 & 0 & 0 & 0 & 0 \\
\hline $35-44$ & 37 & 2 & 64 & 7 & 101 & 54.2 \\
\hline $45-54$ & 378 & 19 & 107 & 11 & 486 & 23 \\
\hline $55-64$ & 134 & 7 & 157 & 16 & 291 & 28.7 \\
\hline 65 or over & 897 & 45 & 400 & 41 & 1,297 & 11.5 \\
\hline No answer & 0 & 0 & 74 & 8 & 74 & 69.7 \\
\hline All other owners & 522 & 27 & 167 & 17 & 688 & 18.8 \\
\hline Total & 1,967 & 100 & 969 & 100 & 2,937 & 0.3 \\
\hline$\overline{S E}$ & 7.1 & & 14.5 & & 0.3 & \\
\hline
\end{tabular}

W-Fewer than 50 owners of less than 0.5 percent 
Table 27. Estimated number of ownership units and acres of forest land, by date of aquisition and form of ownership, Plains States, 1993

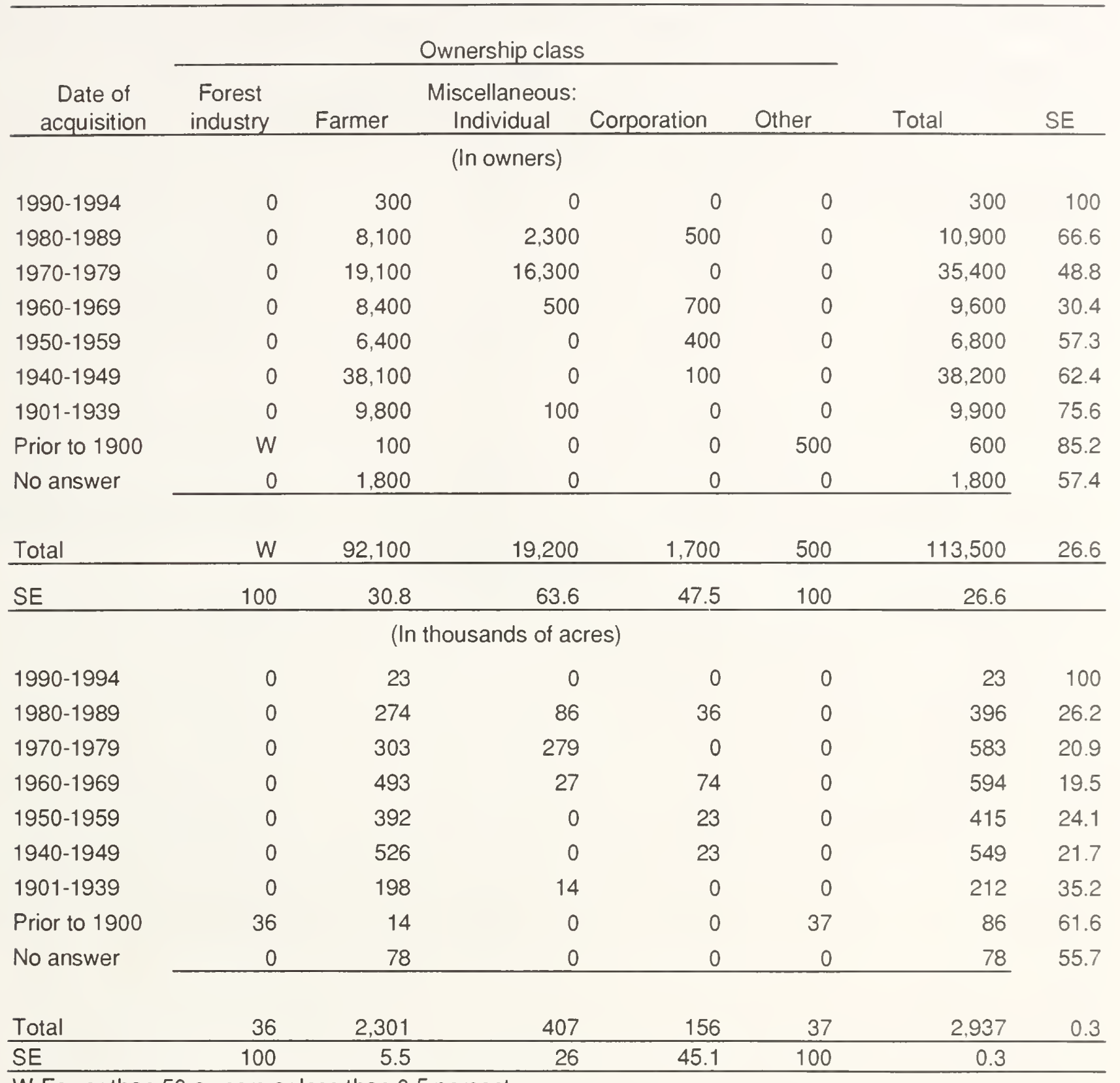

W-Fewer than 50 owners or less than 0.5 percent 
Table 28. Estimated number of ownership units and acres of forest land, by distance from tracts, Plains States, 1993

\begin{tabular}{|c|c|c|c|c|}
\hline \multirow[t]{3}{*}{ Distance } & \multicolumn{3}{|c|}{ Tracts } & \multirow{3}{*}{ Total } \\
\hline & \multirow[b]{2}{*}{1 tract } & \multicolumn{2}{|c|}{ More than one tract } & \\
\hline & & Nearest tract & Farthest tract & \\
\hline \multicolumn{5}{|c|}{ (In owners) } \\
\hline Less than 1 mile & 39,300 & 15,700 & 3,200 & \\
\hline 2-5 miles & 1,000 & 800 & 6,300 & \\
\hline $6-15$ miles & 10,900 & 0 & 6,200 & \\
\hline 16-25 miles & 300 & 0 & 300 & \\
\hline 26-50 miles & 1,200 & 100 & 500 & \\
\hline $51-100$ miles & 0 & 0 & 0 & \\
\hline More than 100 miles & 17,300 & 0 & 100 & \\
\hline No answer & 26,400 & 700 & 700 & \\
\hline Total & 96,200 & 17,300 & 17,300 & 113,500 \\
\hline \multicolumn{5}{|c|}{ (In thousands of acres) } \\
\hline Less than 1 mile & 1,017 & 1,061 & 296 & \\
\hline 2-5 miles & 87 & 74 & 352 & \\
\hline $6-15$ miles & 146 & 0 & 327 & \\
\hline $16-25$ miles & 23 & 0 & 74 & \\
\hline $26-50$ miles & 74 & 14 & 86 & \\
\hline $51-100$ miles & 0 & 0 & 0 & \\
\hline More than 100 miles & 219 & 0 & 14 & \\
\hline No answer & 208 & 14 & 14 & \\
\hline Total & 1,775 & 1,162 & 1,162 & 2,937 \\
\hline
\end{tabular}


Table 29. Estimated number of ownership units and acres of forest land, by primary and secondary reason for owning forest land, Plains States, 1993

\begin{tabular}{|c|c|c|c|c|}
\hline \multirow[t]{2}{*}{ Reason } & \multicolumn{2}{|c|}{ Primary reason } & \multicolumn{2}{|c|}{ Secondary reason } \\
\hline & Number & Percent & Number & Percent \\
\hline & \multicolumn{4}{|c|}{ (In owners) } \\
\hline Land investment & 100 & W & 100 & W \\
\hline Recreation & 7,400 & 7 & 3,000 & 3 \\
\hline Timber production & 800 & 1 & 700 & 1 \\
\hline Farm and domestic use & 18,400 & 16 & 5,800 & 5 \\
\hline Esthetic enjoyment & 2,700 & 2 & 4,900 & 4 \\
\hline Part of farm & 61,300 & 54 & 5,400 & 5 \\
\hline Part of residence & 18,000 & 16 & 4,200 & 4 \\
\hline Estate & 100 & W & 100 & W \\
\hline Other & 3,500 & 3 & 1,400 & 1 \\
\hline No secondary reason given & - & - & 85,800 & 76 \\
\hline No answer & 1,300 & 1 & 1,300 & 1 \\
\hline \multirow[t]{2}{*}{ Total } & 113,500 & 100 & 113,500 & 100 \\
\hline & \multicolumn{4}{|c|}{ (In thousands of acres) } \\
\hline Land investment & 36 & 1 & 73 & 2 \\
\hline Recreation & 340 & 12 & 197 & 7 \\
\hline Timber production & 96 & 3 & 107 & 4 \\
\hline Farm and domestic use & 494 & 17 & 257 & 9 \\
\hline Esthetic enjoyment & 171 & 6 & 320 & 11 \\
\hline Part of farm & 1,242 & 42 & 137 & 5 \\
\hline Part of residence & 312 & 11 & 204 & 7 \\
\hline Estate & 27 & 1 & 143 & 5 \\
\hline Other & 144 & 5 & 83 & 3 \\
\hline No secondary reason given & - & - & 1,340 & 46 \\
\hline No answer & 74 & 2 & 74 & 2 \\
\hline Total & 2,937 & 100 & 2.937 & 100 \\
\hline
\end{tabular}

W-Fewer than 50 owners or less than 0.5 percent 
Table 30. Estimated number of ownership units and acres of forest land, by primary benefit expected in the next 10 years and past harvest experience, Plains States, 1993

\begin{tabular}{|c|c|c|c|c|c|c|}
\hline \multirow[t]{2}{*}{ Benefits expected } & \multicolumn{4}{|c|}{ Harvest Experience } & \multirow{2}{*}{ Total } & \multirow{2}{*}{ SE } \\
\hline & Harvested & Percent & Did not harvest & Percent & & \\
\hline \multicolumn{7}{|c|}{ (In owners) } \\
\hline Land value increase & 1.000 & 3 & 400 & 1 & 1,400 & 49.9 \\
\hline Recreation & 3.500 & 9 & 900 & 1 & 4,400 & 45.5 \\
\hline Income from timber & 800 & 2 & 200 & W & 1,000 & 47 \\
\hline Farm and domestic use & 22,000 & 57 & 19,700 & 26 & 41,700 & 37 \\
\hline Esthetic enjoyment & 8,800 & 23 & 7,600 & 10 & 16,500 & 25.1 \\
\hline Firewood & 1,200 & 3 & 200 & W & 1,400 & 47.6 \\
\hline Other & 1,100 & 3 & 13,400 & 18 & 14,400 & 82.7 \\
\hline No answer & 100 & W & 32,600 & 43 & 32,600 & 74.6 \\
\hline Total & 38,500 & 100 & 75,000 & 100 & 113,500 & 26.6 \\
\hline SE & 32.6 & & 37.6 & & 26.6 & \\
\hline \multicolumn{7}{|c|}{ (In thousands of acres) } \\
\hline Land value increase & 170 & 9 & 49 & 5 & 219 & 38.1 \\
\hline Recreation & 280 & 14 & 111 & 11 & 391 & 26.4 \\
\hline Income from timber & 241 & 12 & 23 & 2 & 264 & 34.3 \\
\hline Farm and domestic use & 614 & 31 & 273 & 28 & 887 & 15.7 \\
\hline Esthetic enjoyment & 405 & 21 & 243 & 25 & 648 & 19 \\
\hline Firewood & 124 & 6 & 14 & 1 & 138 & 40.1 \\
\hline Other & 96 & 5 & 95 & 10 & 191 & 37.2 \\
\hline No answer & 37 & 2 & 161 & 17 & 198 & 38.6 \\
\hline Total & 1.967 & 100 & 969 & 100 & 2,937 & 0.3 \\
\hline SE & 7.1 & & 14.5 & & 0.3 & \\
\hline
\end{tabular}




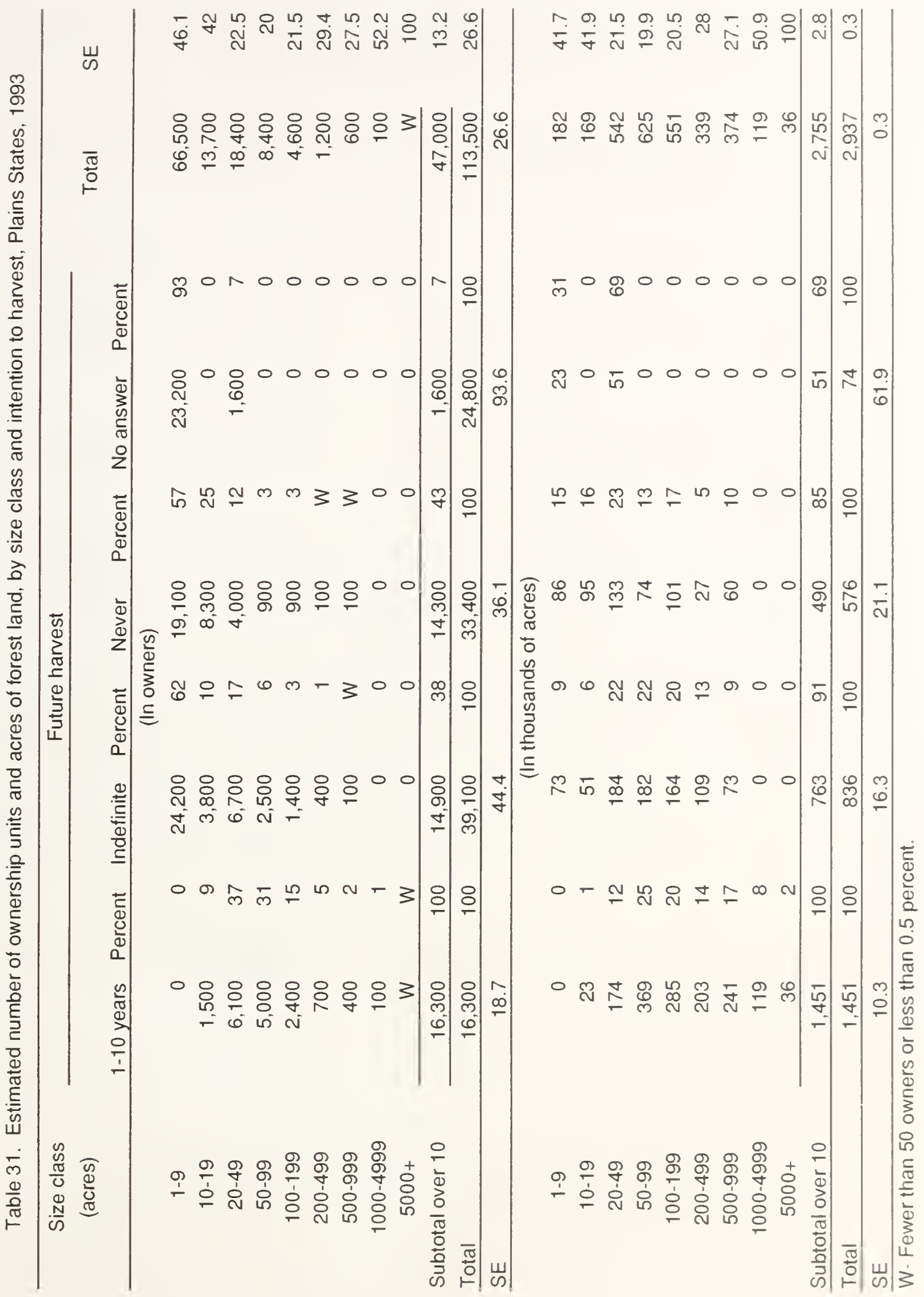




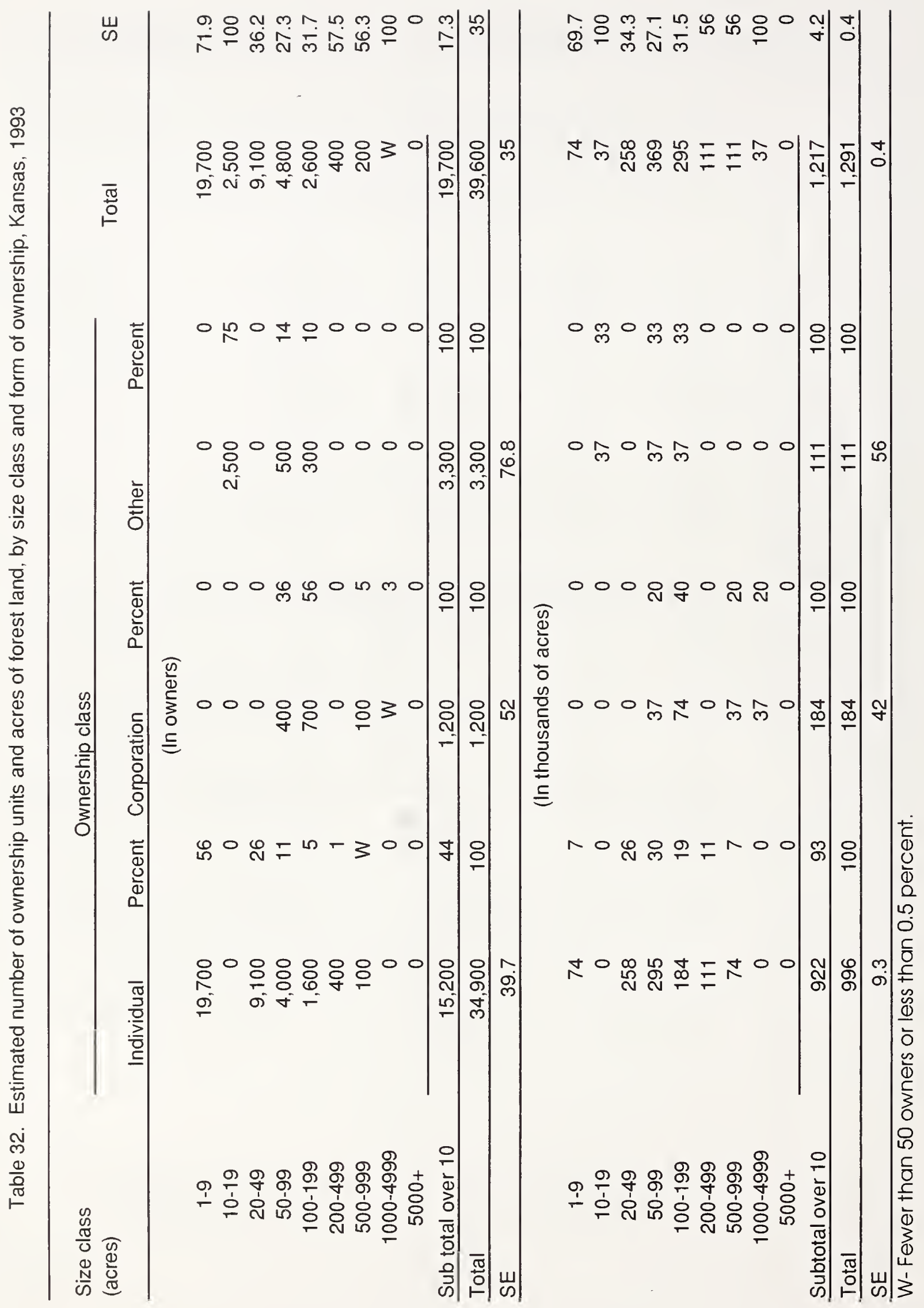


Table 33. Estimated number of ownership units and acres of forest land, by form of ownership and past harvest experience, Kansas, 1993

Form of ownership

Harvest experience

Total

SE

Harvested Percent Did notharvest Percent

(In owners)

\begin{tabular}{lrrrrrr} 
Individual + joint & 24,500 & 87 & 10,400 & 93 & 34,900 & 39.7 \\
Partnership & 2,800 & 10 & 0 & 0 & 2,800 & 88.5 \\
Corporation & 800 & 3 & 400 & 3 & 1,200 & 52.3 \\
Club/association & 0 & 0 & 500 & 4 & 500 & 100 \\
Other & 0 & 0 & 0 & 0 & 0 & 0 \\
Total & 28,100 & 100 & 11,200 & 100 & 39,300 & 35 \\
\hline SE & 43.9 & & 66.1 & & 35 & \\
\hline & & (In thousands of acres) & & & & \\
Individual + joint & 738 & 77 & 258 & 78 & 996 & 9.3 \\
Partnership & 74 & 8 & 0 & 0 & 74 & 69.7 \\
Corporation & 147 & 15 & 37 & 11 & 184 & 42 \\
Club/association & 0 & 0 & 37 & 11 & 37 & 100 \\
Other & 0 & 0 & 0 & 0 & 0 & 0 \\
Total & 959 & 100 & 332 & 100 & 1,291 & 0.4 \\
\hline SE & 10.1 & & 29.2 & & 0.4 & \\
\hline
\end{tabular}


Table 34. Estimated number of ownership units and acres of forest land, by incorporated and unincorporated businesses and past harvest experience, Kansas, 1993

\begin{tabular}{|c|c|c|c|c|c|c|}
\hline \multirow[t]{2}{*}{ Nature of business } & \multicolumn{4}{|c|}{ Harvest } & \multirow{2}{*}{ Total } & \multirow{2}{*}{ SE } \\
\hline & Harvested & Percent & Did not harvest & Percent & & \\
\hline \multicolumn{7}{|c|}{ (In owners) } \\
\hline \multicolumn{7}{|l|}{ Incorporated: } \\
\hline Farm & 100 & $W$ & 400 & 3 & 500 & 81.4 \\
\hline Sport/ recreation club & 400 & 1 & 0 & 0 & 400 & 100 \\
\hline Other & 300 & 1 & 0 & 0 & 300 & 100 \\
\hline Total corporate & 800 & 3 & 400 & 3 & 1,200 & 52.3 \\
\hline \multicolumn{7}{|l|}{ Unincorporated: } \\
\hline Farm & 23,700 & 84 & 9,500 & 84 & 33,200 & 42.2 \\
\hline Misc. individual & 3,600 & 13 & 900 & 8 & 4,500 & 49.3 \\
\hline Sport/ recreation club & 0 & 0 & 500 & 4 & 500 & 100 \\
\hline Other & 0 & 0 & 0 & 0 & 0 & 0 \\
\hline Total noncorporate & 27,300 & 97 & 10,800 & 97 & 38,200 & 36.2 \\
\hline Total & 28,100 & 100 & 11,200 & 100 & 39,300 & 35 \\
\hline SE & 43.9 & & 66.1 & & 35 & \\
\hline \multicolumn{7}{|c|}{ (In thousands of acres) } \\
\hline Incorporated: & & & & & & \\
\hline Farm & 74 & 8 & 37 & 11 & 111 & 56 \\
\hline Sport/ recreation club & 37 & 4 & 0 & 0 & 37 & 100 \\
\hline Other & 37 & 4 & 0 & 0 & 37 & 100 \\
\hline Total corporate & 147 & 15 & 37 & 11 & 184 & 42 \\
\hline \multicolumn{7}{|l|}{ Unincorporated: } \\
\hline Farm & 664 & 69 & 221 & 67 & 885 & 11.6 \\
\hline Misc. individual & 147 & 15 & 37 & 11 & 184 & 42 \\
\hline Sport/ recreation club & 0 & 0 & 37 & 11 & 37 & 100 \\
\hline Other & 0 & 0 & 0 & 0 & 0 & 0 \\
\hline Total noncorporate & 811 & 85 & 295 & 89 & 1,107 & 7 \\
\hline Total & 959 & 100 & 332 & 100 & 1,291 & 0.4 \\
\hline SE & 10.1 & & 29.2 & & 0.4 & \\
\hline
\end{tabular}

W- Fewer than 50 owners or less than 0.5 percent 


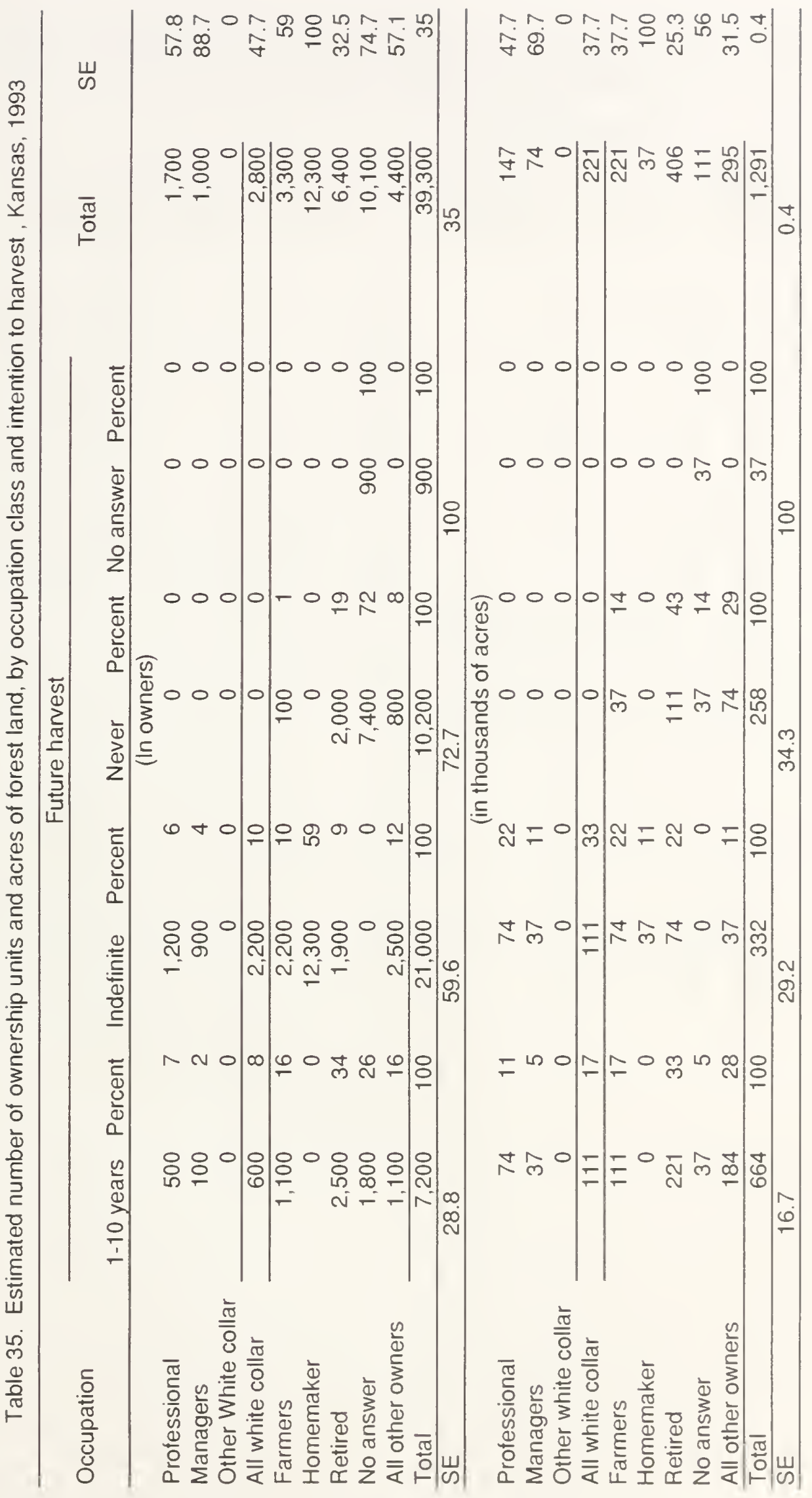


Table 36. Estimated number of ownership units and acres of forest land, by age class and past harvest experience, Kansas, 1993

\begin{tabular}{|c|c|c|c|c|c|c|}
\hline \multirow[t]{2}{*}{ Age } & \multicolumn{4}{|c|}{ Harvest experience } & \multirow{2}{*}{ Total } & \multirow{2}{*}{ SE } \\
\hline & Harvested & Percent & Did not harvest & Percent & & \\
\hline \multicolumn{7}{|c|}{ (In owners) } \\
\hline $35-44$ & 100 & W & 900 & 8 & 1,000 & 89.3 \\
\hline $45-54$ & 3,200 & 11 & 0 & 0 & 3,200 & 60.7 \\
\hline $55-64$ & 1,500 & 5 & 400 & 3 & 1,900 & 79.9 \\
\hline 65 or over & 19,700 & 70 & 800 & 7 & 20,500 & 60 \\
\hline No answer & 0 & 0 & 8,300 & 74 & 8,300 & 89.3 \\
\hline All other owners & 3,600 & 13 & 800 & 7 & 4,400 & 57.1 \\
\hline Total & 28,100 & 100 & 11,200 & 100 & 39,300 & 35 \\
\hline SE & 43.9 & & 66.1 & & 35 & \\
\hline \multicolumn{7}{|c|}{ (In thousands of acres) } \\
\hline $35-44$ & 37 & 4 & 37 & 11 & 74 & 69.7 \\
\hline $45-54$ & 184 & 19 & 0 & 0 & 184 & 42 \\
\hline $55-64$ & 37 & 4 & 64 & 22 & 111 & 56 \\
\hline 65 or over & 479 & 50 & 74 & 22 & 553 & 19.8 \\
\hline No answer & 0 & 0 & 74 & 22 & 74 & 69.7 \\
\hline All other owners & 221 & 23 & 74 & 22 & 295 & 31.5 \\
\hline Total & 959 & 100 & 332 & 100 & 1,291 & 0.5 \\
\hline SE & 10.1 & 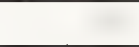 & 29.2 & & 0.4 & \\
\hline
\end{tabular}

W-Fewer than 50 owners of less than 0.5 percent 
Table 37. Estimated number of ownership units and acres of forest land, by date of aquisition and form of ownership, Kansas, 1993

Ownership class

\begin{tabular}{|c|c|c|c|c|c|c|c|}
\hline $\begin{array}{c}\text { Date of } \\
\text { acquisition }\end{array}$ & $\begin{array}{c}\text { Forest } \\
\text { industry }\end{array}$ & Farmer & $\begin{array}{l}\text { Miscellaneous: } \\
\text { Individual }\end{array}$ & Corporation & Other & Total & SE \\
\hline \multicolumn{8}{|c|}{ (In owners) } \\
\hline $1990-1994$ & 0 & 0 & 0 & 0 & 0 & 0 & 0 \\
\hline $1980-1989$ & 0 & 200 & 500 & 0 & 0 & 800 & 70.9 \\
\hline $1970-1979$ & 0 & 14,700 & 4,000 & 0 & 0 & 18,700 & 66.5 \\
\hline $1960-1969$ & 0 & 4,200 & 0 & 700 & 0 & 4,900 & 28.8 \\
\hline $1950-1959$ & 0 & 1,800 & 0 & 0 & 0 & 1,800 & 84 \\
\hline $1940-1949$ & 0 & 3,600 & 0 & 0 & 0 & 3,600 & 68.9 \\
\hline $1901-1939$ & 0 & 8,800 & 0 & 0 & 0 & 8,800 & 84.6 \\
\hline Prior to 1900 & 0 & 0 & 0 & 0 & 500 & 500 & 100 \\
\hline No answer & 0 & 400 & 0 & 0 & 0 & 400 & 100 \\
\hline Total & 0 & 33,600 & 4,500 & 700 & 500 & 39,300 & 35 \\
\hline SE & 0 & 41.6 & 49.3 & 70.8 & 100 & 35 & \\
\hline \multicolumn{8}{|c|}{ (In thousands of acres) } \\
\hline $1990-1994$ & 0 & 0 & 0 & 0 & 0 & 0 & 0 \\
\hline $1980-1989$ & 0 & 74 & 37 & 0 & 0 & 111 & 56 \\
\hline $1970-1979$ & 0 & 111 & 147 & 0 & 0 & 258 & 34.3 \\
\hline $1960-1969$ & 0 & 369 & 0 & 74 & 0 & 443 & 23.7 \\
\hline $1950-1959$ & 0 & 74 & 0 & 0 & 0 & 74 & 69.7 \\
\hline $1940-1949$ & 0 & 221 & 0 & 0 & 0 & 221 & 37.7 \\
\hline $1901-1939$ & 0 & 111 & 0 & 0 & 0 & 111 & 56 \\
\hline Prior to 1900 & 0 & 0 & 0 & 0 & 37 & 37 & 100 \\
\hline No answer & 0 & 37 & 0 & 0 & 0 & 37 & 100 \\
\hline Total & 0 & 996 & 184 & 74 & 37 & 1,291 & 0.4 \\
\hline SE & 0 & 9.3 & 42 & 69.7 & 100 & 0.4 & \\
\hline
\end{tabular}


Table 38. Estimated number of ownership units and acres of forest land, by distance from tracts, Kansas, 1993

\begin{tabular}{|c|c|c|c|c|}
\hline \multirow{3}{*}{ Distance } & \multicolumn{3}{|c|}{ Tracts } & \multirow{3}{*}{ Total } \\
\hline & \multirow[b]{2}{*}{1 tract } & \multicolumn{2}{|c|}{ More than one tract } & \\
\hline & & Nearest tract & Farthest tract & \\
\hline \multicolumn{5}{|c|}{ (In owners) } \\
\hline Less than 1 mile & 12,100 & 6,200 & 2,100 & \\
\hline $2-5$ miles & 900 & 800 & 2,800 & \\
\hline 6-15 miles & 1,500 & 0 & 1,400 & \\
\hline $16-25$ miles & 0 & 0 & 300 & \\
\hline $26-50$ miles & 1,200 & 0 & 400 & \\
\hline $51-100$ miles & 0 & 0 & 0 & \\
\hline More than 100 miles & 14,800 & 0 & 0 & \\
\hline No answer & 1,800 & 0 & 0 & \\
\hline Total & 32,300 & 7,000 & 7,000 & 39,300 \\
\hline \multicolumn{5}{|c|}{ (In thousands of acres) } \\
\hline Less than 1 mile & 369 & 479 & 111 & \\
\hline $2-5$ miles & 74 & 74 & 147 & \\
\hline $6-15$ miles & 37 & 0 & 184 & \\
\hline $16-25$ miles & 0 & 0 & 74 & \\
\hline $26-50$ miles & 74 & 0 & 37 & \\
\hline $51-100$ miles & 0 & 0 & 0 & \\
\hline More than 100 miles & 74 & 0 & 0 & \\
\hline No answer & 111 & 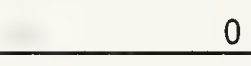 & 0 & \\
\hline Total & 738 & 553 & 553 & 1,291 \\
\hline
\end{tabular}


Table 39. Estimated number of ownership units and acres of forest land, by primary and secondary reason for owning forest land, Kansas, 1993

\begin{tabular}{|c|c|c|c|c|}
\hline \multirow[t]{2}{*}{ Reason } & \multicolumn{2}{|c|}{ Primary reason } & \multicolumn{2}{|c|}{ Secondary reason } \\
\hline & Number & Percent & Number & Percent \\
\hline & \multicolumn{4}{|c|}{ (In owners) } \\
\hline Land investment & 0 & 0 & 100 & W \\
\hline Recreation & 2,600 & 7 & 900 & 2 \\
\hline Timber production & 500 & 1 & 0 & 0 \\
\hline Farm and domestic use & 1,500 & 4 & 1,600 & 4 \\
\hline Esthetic enjoyment & 1,600 & 4 & 1,500 & 4 \\
\hline Part of farm & 28,100 & 72 & 400 & 1 \\
\hline Part of residence & 3,700 & 9 & 1,200 & 3 \\
\hline Estate & 0 & 0 & 900 & 2 \\
\hline Other & 0 & 0 & 300 & 1 \\
\hline No secondary reason given & - & - & 31,100 & 79 \\
\hline No answer & 1,300 & 3 & 1,300 & 3 \\
\hline \multirow[t]{2}{*}{ Total } & 39,300 & 100 & 39,300 & 100 \\
\hline & \multicolumn{4}{|c|}{ (In thousands of acres) } \\
\hline Land investment & 0 & 0 & 37 & 3 \\
\hline Recreation & 184 & 14 & 74 & 6 \\
\hline Timber production & 37 & 3 & 0 & 0 \\
\hline Farm and domestic use & 147 & 11 & 111 & 9 \\
\hline Esthetic enjoyment & 111 & 9 & 147 & 11 \\
\hline Part of farm & 553 & 43 & 37 & 3 \\
\hline Part of residence & 184 & 14 & 37 & 3 \\
\hline Estate & 0 & 0 & 74 & 6 \\
\hline Other & 0 & 0 & 37 & 3 \\
\hline No secondary reason given & - & - & 664 & 51 \\
\hline No answer & 74 & 6 & 74 & 6 \\
\hline Total & 1,291 & 100 & 1,291 & 100 \\
\hline
\end{tabular}


Table 40. Estimated number of ownership units and acres of forest land, by primary benefit expected in the next 10 years and past harvest experience, Kansas, 1993

\begin{tabular}{|c|c|c|c|c|c|c|}
\hline \multirow[t]{2}{*}{ Benefits expected } & \multicolumn{4}{|c|}{ Harvest Experience } & \multirow{2}{*}{ Total } & \multirow{2}{*}{ SE } \\
\hline & Harvested & Percent & Did not harvest & Percent & & \\
\hline \multicolumn{7}{|c|}{ (In owners) } \\
\hline Land value increase & 900 & 3 & 0 & 0 & 900 & 69 \\
\hline Recreation & 2,300 & 8 & 400 & 4 & 2,700 & 68.2 \\
\hline Income from timber & 600 & 2 & 0 & 0 & 600 & 66.1 \\
\hline Farm and domestic use & 19,300 & 69 & 700 & 7 & 20,000 & 62.2 \\
\hline Esthetic enjoyment & 4,400 & 16 & 1,400 & 12 & 5,800 & 39 \\
\hline Firewood & 500 & 2 & 0 & 0 & 500 & 100 \\
\hline No answer & 100 & W & 8.700 & 77 & 8,700 & 84.9 \\
\hline Total & 28,100 & 100 & 11,200 & 100 & 39,300 & 35 \\
\hline SE & 43.9 & & 66.1 & & 35 & \\
\hline \multicolumn{7}{|c|}{ (In thousands of acres) } \\
\hline Land value increase & 111 & 11 & 0 & 0 & 111 & 56 \\
\hline Recreation & 147 & 15 & 74 & 22 & 221 & 37.7 \\
\hline Income from timber & 111 & 11 & 0 & 0 & 111 & 56 \\
\hline Farm and domestic use & 295 & 31 & 74 & 22 & 369 & 27.1 \\
\hline Esthetic enjoyment & 221 & 23 & 74 & 22 & 295 & 31.5 \\
\hline Firewood & 37 & 4 & 0 & 0 & 37 & 100 \\
\hline No answer & 37 & 4 & 111 & 33 & 147 & 47.7 \\
\hline Total & 959 & 100 & 332 & 100 & 1,291 & 0.4 \\
\hline SE & 10.1 & & 29.2 & & 0.4 & \\
\hline
\end{tabular}




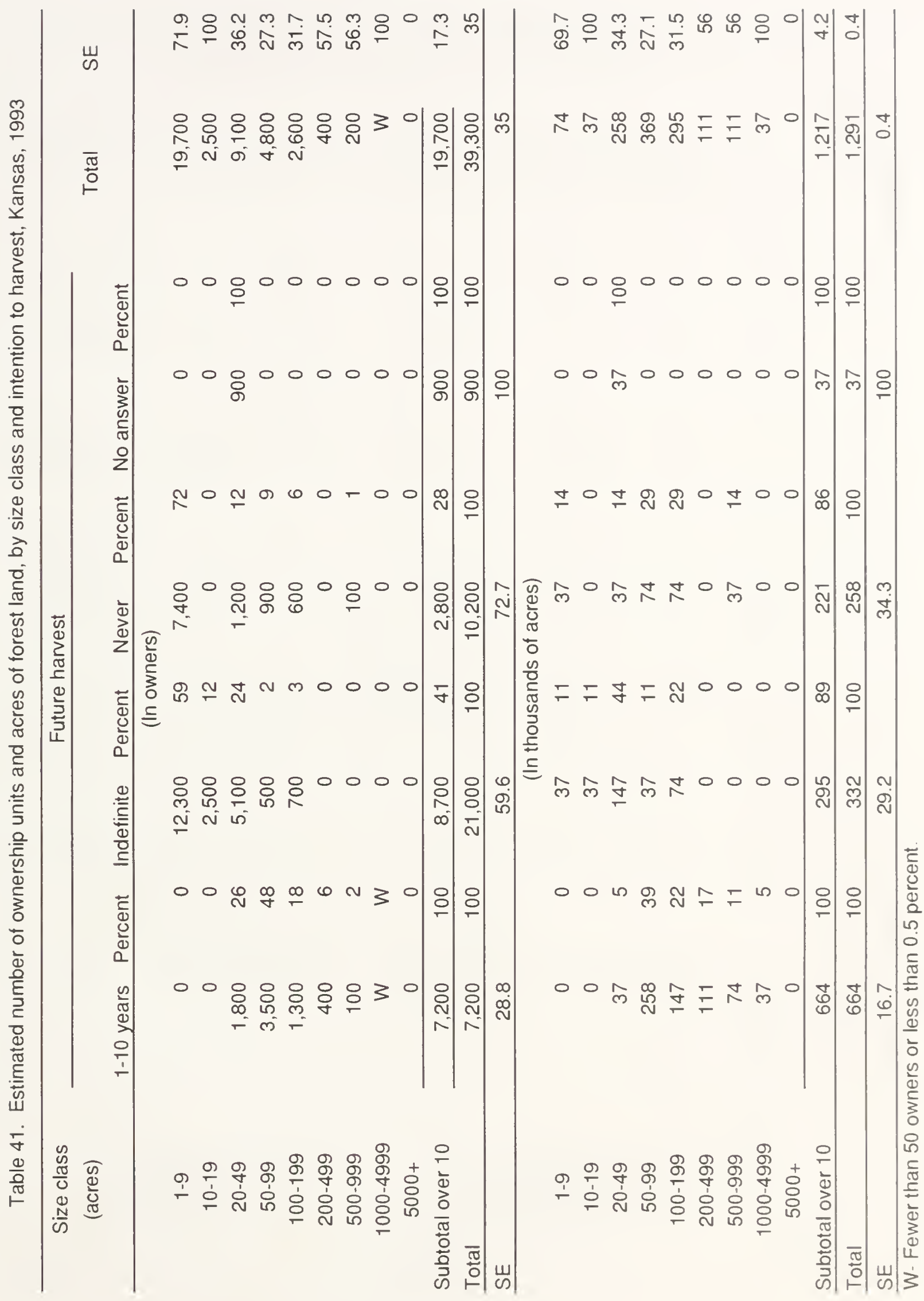




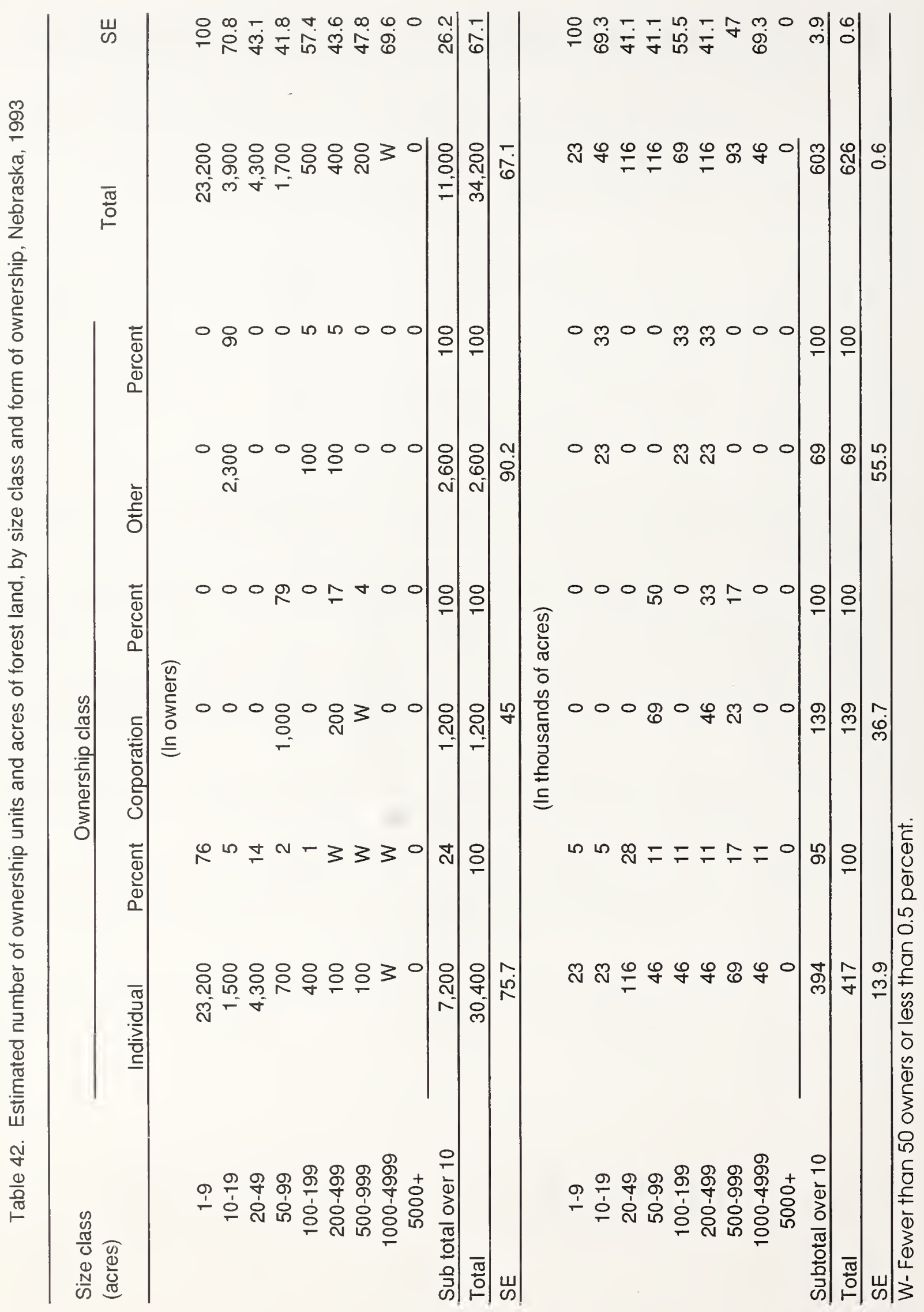


Table 43. Estimated number of ownership units and acres of forest land, by form of ownership and past harvest expcrience, Nebraska, 1993

\begin{tabular}{|c|c|c|c|c|c|c|}
\hline \multirow[t]{2}{*}{ Form of ownership } & \multicolumn{4}{|c|}{ Harvest experience } & \multirow{2}{*}{ Total } & \multirow{2}{*}{ SE } \\
\hline & Harvested & Percent & Did not harvest & Percent & & \\
\hline \multicolumn{7}{|c|}{ (In owners) } \\
\hline Individual + joint & 4,800 & 87 & 25,600 & 89 & 30.400 & 75.7 \\
\hline Partnership & 200 & 4 & 2,300 & 8 & 2,600 & 90.2 \\
\hline Corporation & 500 & 9 & 700 & 3 & 1,200 & 45 \\
\hline Club/association & 0 & 0 & 0 & 0 & 0 & 0 \\
\hline Other & 0 & 0 & 0 & 0 & 0 & 0 \\
\hline Total & 5,500 & 100 & 28,700 & 100 & 34,200 & 67.1 \\
\hline SE & 34.1 & & 80.7 & & 67.1 & \\
\hline \multicolumn{7}{|c|}{ (In thousands of acres) } \\
\hline Individual + joint & 301 & 72 & 116 & 55 & 417 & 13.9 \\
\hline Partnership & 46 & 11 & 23 & 11 & 69 & 55.5 \\
\hline Corporation & 69 & 17 & 69 & 33 & 139 & 36.7 \\
\hline Club/association & 0 & 0 & 0 & 0 & 0 & 0 \\
\hline Other & 0 & 0 & 0 & 0 & $\underline{0}$ & 0 \\
\hline Total & 417 & 100 & 209 & 100 & 626 & 0.6 \\
\hline SE & 13.9 & & 27.7 & & 0.6 & \\
\hline
\end{tabular}


Table 44. Estimated number of ownership units and acres of forest land, by incorporated and unincorporated businesses and past harvest experience, Nebraska, 1993

\begin{tabular}{|c|c|c|c|c|c|c|}
\hline \multirow[t]{2}{*}{ Nature of business } & \multicolumn{4}{|c|}{ Harvest } & \multirow{2}{*}{ Total } & \multirow{2}{*}{ SE } \\
\hline & Harvested & Percent & Did not harvest & Percent & & \\
\hline \multicolumn{7}{|c|}{ (In owners) } \\
\hline \multicolumn{7}{|l|}{ Incorporated: } \\
\hline Farm & 400 & 7 & 300 & 1 & 700 & 56.6 \\
\hline Sport/ recreation club & 100 & 2 & 0 & 0 & 100 & 100 \\
\hline Other & 0 & 0 & 400 & 1 & 400 & 100 \\
\hline Total corporate & 500 & 9 & 700 & 3 & 1,200 & 45 \\
\hline \multicolumn{7}{|l|}{ Unincorporated: } \\
\hline Farm & 5,000 & 90 & 27,900 & 97 & 32,900 & 70 \\
\hline Misc. individual & W & 1 & 100 & W & 100 & 71.1 \\
\hline Sport/ recreation club & 0 & 0 & 0 & 0 & 0 & 0 \\
\hline Other & 0 & 0 & 0 & 0 & 0 & 0 \\
\hline Total noncorporate & 5,000 & 91 & 27,900 & 97 & 33,000 & 69.8 \\
\hline Total & 5,500 & 100 & 28,700 & 100 & 34,200 & 67.1 \\
\hline SE & 34.1 & & 80.7 & & 67.1 & \\
\hline \multicolumn{7}{|c|}{ (In thousands of acres) } \\
\hline $\begin{array}{l}\text { Incorporated: } \\
\text { Farm }\end{array}$ & 46 & 11 & 46 & 22 & 93 & 47 \\
\hline Sport/ recreation club & 23 & 5 & 0 & 0 & 23 & 100 \\
\hline Other & 9 & 0 & 23 & 11 & 23 & 100 \\
\hline Total corporate & 69 & 17 & 69 & 33 & 139 & 36.7 \\
\hline \multicolumn{7}{|l|}{ Unincorporated: } \\
\hline Farm & 325 & 78 & 116 & 55 & 441 & 12.7 \\
\hline Misc. individual & 23 & 5 & 23 & 11 & 46 & 69.3 \\
\hline Sport/ recreation club & 0 & 0 & 0 & 0 & 0 & 0 \\
\hline Other & 0 & 0 & 0 & 0 & 0 & 0 \\
\hline Total noncorporate & 348 & 83 & 139 & 67 & 487 & 10.5 \\
\hline Total & 417 & 100 & 209 & 100 & 626 & 0.6 \\
\hline SE & 13.9 & & 27.7 & & 0.6 & \\
\hline
\end{tabular}

W- Fewer than 50 owners or less than 0.5 percent 


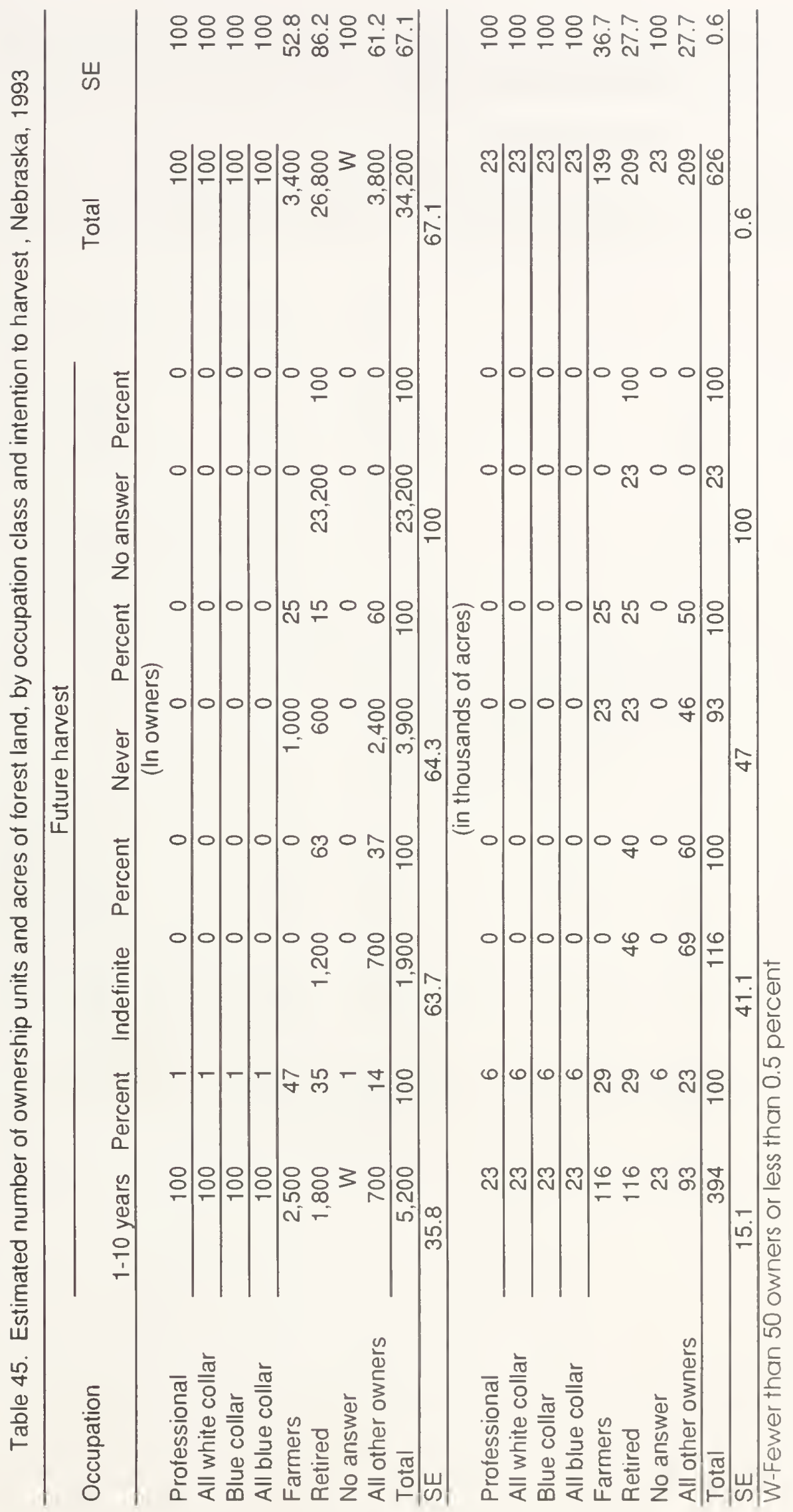


Table 46. Estimated number of ownership units and acres of forest land, by age class and past harvest experience, Nebraska, 1993

\begin{tabular}{|c|c|c|c|c|c|c|}
\hline \multirow[t]{2}{*}{ Age } & \multicolumn{4}{|c|}{ Harvest experience } & \multirow{2}{*}{ Total } & \multirow{2}{*}{ SE } \\
\hline & Harvested & Percent & Did not harvest & Percent & & \\
\hline \multicolumn{7}{|c|}{ (In owners) } \\
\hline Under 25 & 0 & 0 & 0 & 0 & 0 & 0 \\
\hline $25-34$ & 0 & 0 & 0 & 0 & 0 & 0 \\
\hline $35-44$ & 0 & 0 & 0 & 0 & 0 & 0 \\
\hline $45-54$ & 300 & 5 & 0 & 0 & 300 & 100 \\
\hline $55-64$ & 100 & 2 & 2,200 & 7 & 2,300 & 64.1 \\
\hline 65 or over & 4,400 & 79 & 23,400 & 82 & 27,800 & 83 \\
\hline No answer & 0 & 0 & 0 & 0 & 0 & 0 \\
\hline All other owners & 700 & 13 & 3,100 & 11 & 3,800 & 61.2 \\
\hline Total & 5,500 & 100 & 28,700 & 100 & 34,200 & 67.1 \\
\hline SE & 34.1 & & 80.7 & & 67.1 & \\
\hline \multicolumn{7}{|c|}{ (In thousands of acres) } \\
\hline Under 25 & 0 & 0 & 0 & 0 & 0 & 0 \\
\hline $25-34$ & 0 & 0 & 0 & 0 & 0 & 0 \\
\hline $35-44$ & 0 & 0 & 0 & 0 & 0 & 0 \\
\hline $45-54$ & 23 & 5 & 0 & 0 & 23 & 100 \\
\hline $55-64$ & 69 & 17 & 69 & 33 & 139 & 36.7 \\
\hline 65 or over & 209 & 50 & 46 & 22 & 255 & 23.7 \\
\hline No answer & 0 & 0 & 0 & 0 & 0 & 0 \\
\hline All other owners & 116 & 28 & 93 & 44 & 209 & 27.7 \\
\hline Total & 417 & 100 & 209 & 100 & 626 & 0.6 \\
\hline SE & 13.9 & & 27.7 & & 0.6 & \\
\hline
\end{tabular}


Table 47. Estimated number of ownership units and acres of forest land, by date of aquisition and form of ownership, Nebraska, 1993

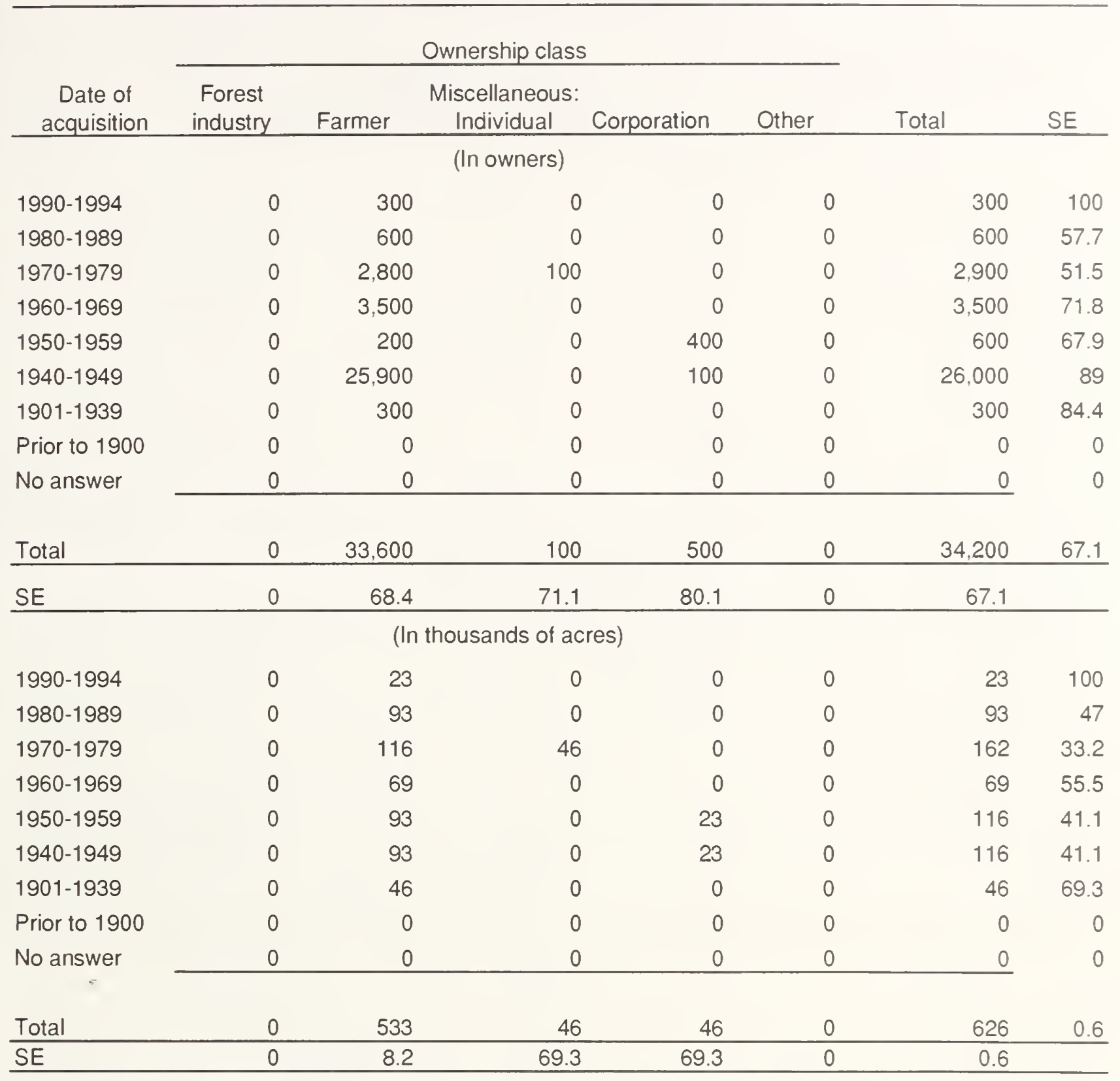


Table 48. Estimated number of ownership units and acres of forest land, by distance from tracts, Nebraska, 1993

\begin{tabular}{|c|c|c|c|c|}
\hline \multirow[t]{3}{*}{ Distance } & \multicolumn{3}{|c|}{ Tracts } & \multirow{3}{*}{ Total } \\
\hline & \multirow[b]{2}{*}{1 tract } & \multicolumn{2}{|c|}{ More than one tract } & \\
\hline & & Nearest tract & Farthest tract & \\
\hline \multicolumn{5}{|c|}{ (In owners) } \\
\hline Less than 1 mile & 2,700 & 4,500 & 600 & \\
\hline $2-5$ miles & 0 & 0 & 2,800 & \\
\hline 6-15 miles & 1,600 & 0 & 1,200 & \\
\hline 16-25 miles & W & 0 & 0 & \\
\hline 26-50 miles & 0 & 0 & 0 & \\
\hline $51-100$ miles & 0 & 0 & 0 & \\
\hline More than 100 miles & 1,400 & 0 & 0 & \\
\hline No answer & 23,900 & 0 & 0 & \\
\hline Total & 29,700 & 4,500 & 4,500 & 34,200 \\
\hline \multicolumn{5}{|c|}{ (In thousands of acres) } \\
\hline Less than 1 mile & 255 & 185 & 23 & \\
\hline $2-5$ miles & 0 & 0 & 69 & \\
\hline $6-15$ miles & 46 & 0 & 93 & \\
\hline $16-25$ miles & 23 & 0 & 0 & \\
\hline $26-50$ miles & 0 & 0 & 0 & \\
\hline $51-100$ miles & 0 & 0 & 0 & \\
\hline More than 100 miles & 46 & 0 & 0 & \\
\hline No answer & 69 & 0 & 0 & \\
\hline Total & 441 & 185 & 185 & 626 \\
\hline
\end{tabular}

W-Fewer than 50 owners or less than 0.5 percent 
Table 49. Estimated number of ownership units and acres of forest land, by primary and secondary reason for owning forest land, Nebraska, 1993

\begin{tabular}{|c|c|c|c|c|}
\hline \multirow[t]{2}{*}{ Reason } & \multicolumn{2}{|c|}{ Primary reason } & \multicolumn{2}{|c|}{ Secondary reason } \\
\hline & Number & Percent & Number & Percent \\
\hline & \multicolumn{4}{|c|}{ (In owners) } \\
\hline Land investment & 0 & 0 & 0 & 0 \\
\hline Recreation & 900 & 3 & 1,200 & 3 \\
\hline Timber production & 200 & 1 & 0 & 0 \\
\hline Farm and domestic use & 900 & 3 & 400 & 1 \\
\hline Esthetic enjoyment & 1,000 & 3 & 1,000 & 3 \\
\hline Part of farm & 28,700 & 84 & 200 & 1 \\
\hline Part of residence & W & W & 300 & 1 \\
\hline Estate & 0 & 0 & 200 & 1 \\
\hline Other & 2,300 & 7 & 1,100 & 3 \\
\hline No secondary reason given & - & - & 29,900 & 87 \\
\hline No answer & 0 & 0 & 0 & 0 \\
\hline \multirow[t]{2}{*}{ Total } & 34,200 & 100 & 34,200 & 100 \\
\hline & \multicolumn{4}{|c|}{ (In thousands of acres) } \\
\hline Land investment & 0 & 0 & 0 & 0 \\
\hline Recreation & 93 & 15 & 46 & 7 \\
\hline Timber production & 23 & 4 & 0 & 0 \\
\hline Farm and domestic use & 116 & 19 & 69 & 11 \\
\hline Esthetic enjoyment & 46 & 7 & 46 & 7 \\
\hline Part of farm & 301 & 48 & 23 & 4 \\
\hline Part of residence & 23 & 4 & 46 & 7 \\
\hline Estate & 0 & 0 & 69 & 11 \\
\hline Other & 23 & 4 & 46 & 7 \\
\hline No secondary reason given & - & - & 278 & 51 \\
\hline No answer & 0 & 0 & 0 & 0 \\
\hline Total & 626 & 100 & 626 & 100 \\
\hline
\end{tabular}

W-Fewer than 50 owners or less than 0.5 percent 
Table 50. Estimated number of ownership units and acres of forest land, by primary benefit expected in the next 10 years and past harvest experience, Nebraska, 1993

\begin{tabular}{|c|c|c|c|c|c|c|}
\hline \multirow[t]{2}{*}{ Benefits expected } & \multicolumn{4}{|c|}{ Harvest Experience } & \multirow{2}{*}{ Total } & \multirow{2}{*}{ SE } \\
\hline & Harvested & Percent & Did not harvest & Percent & & \\
\hline \multicolumn{7}{|c|}{ (In owners) } \\
\hline Land value increase & W & 1 & 0 & 0 & W & 100 \\
\hline Recreation & 500 & 10 & 400 & 1 & 900 & 58.9 \\
\hline Income from timber & 100 & 1 & 200 & 1 & 300 & 81.7 \\
\hline Farm and domestic use & 1,100 & 19 & W & W & 1,100 & 58.4 \\
\hline Esthetic enjoyment & 3,500 & 63 & 3,800 & 13 & 7,300 & 41.4 \\
\hline Firewood & 100 & 3 & 0 & 0 & 100 & 73.4 \\
\hline Other & 200 & 4 & 1.000 & 3 & 1,200 & 80.1 \\
\hline No answer & 0 & 0 & 23,200 & 81 & 23,200 & 100 \\
\hline Total & 5,500 & 100 & 28,700 & 100 & 34,200 & 67.1 \\
\hline SE & 34.1 & & 80.7 & & 67.1 & \\
\hline \multicolumn{7}{|c|}{ (In thousands of acres) } \\
\hline Land value increase & 23 & 5 & 0 & 0 & 23 & 100 \\
\hline Recreation & 69 & 17 & 23 & 11 & 93 & 47 \\
\hline Income from timber & 23 & 5 & 23 & 11 & 46 & 69.3 \\
\hline Farm and domestic use & 116 & 28 & 23 & 11 & 139 & 36.7 \\
\hline Esthetic enjoyment & 93 & 22 & 93 & 44 & 185 & 30.2 \\
\hline Firewood & 46 & 11 & 0 & 0 & 46 & 69.3 \\
\hline Other & 46 & 11 & 23 & 11 & 69 & 55.5 \\
\hline No answer & 0 & 0 & 23 & 11 & 23 & 100 \\
\hline Total & 417 & 100 & 209 & 100 & 626 & 0.6 \\
\hline SE & 13.9 & 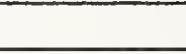 & 27.7 & & 0.6 & \\
\hline
\end{tabular}




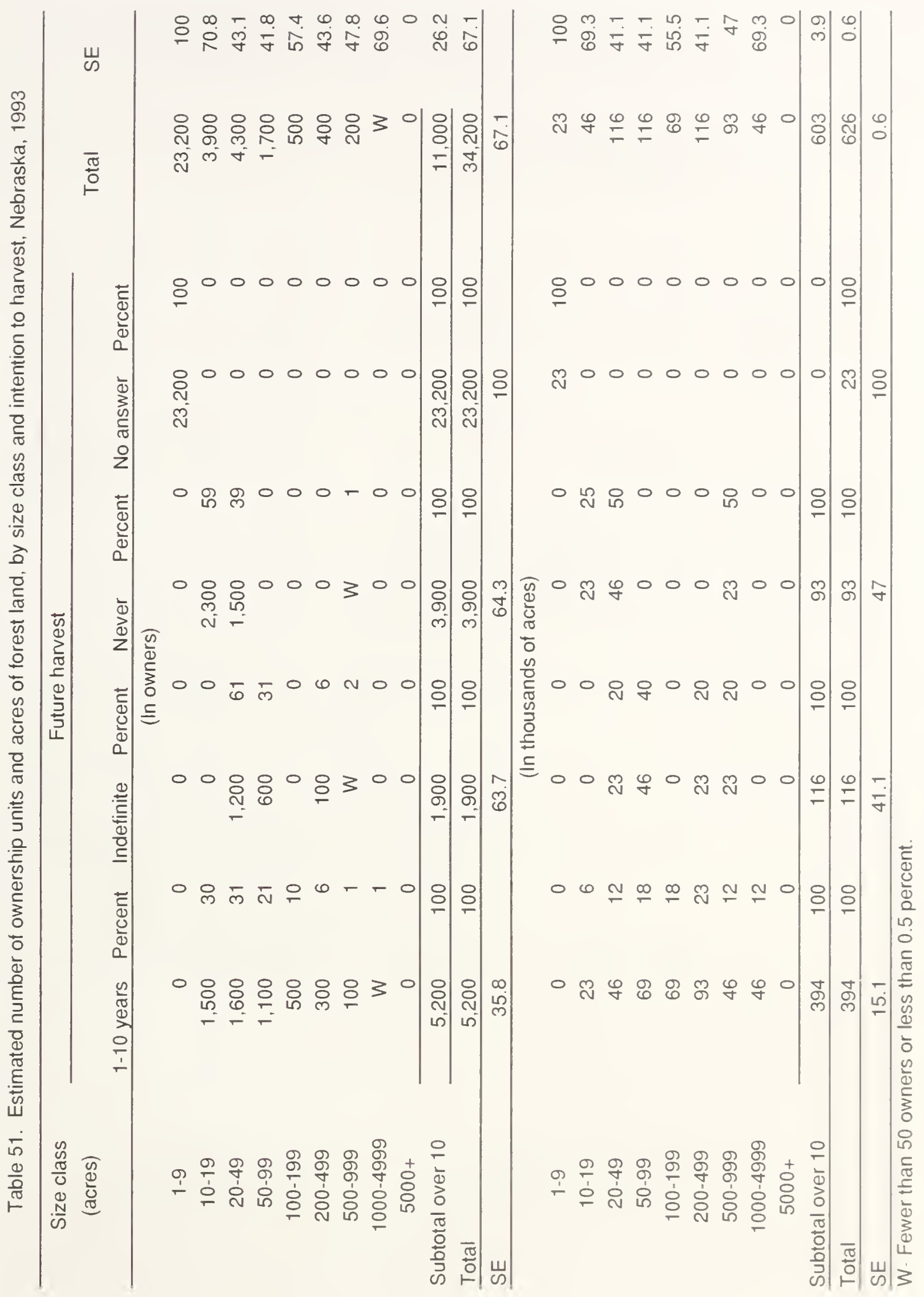




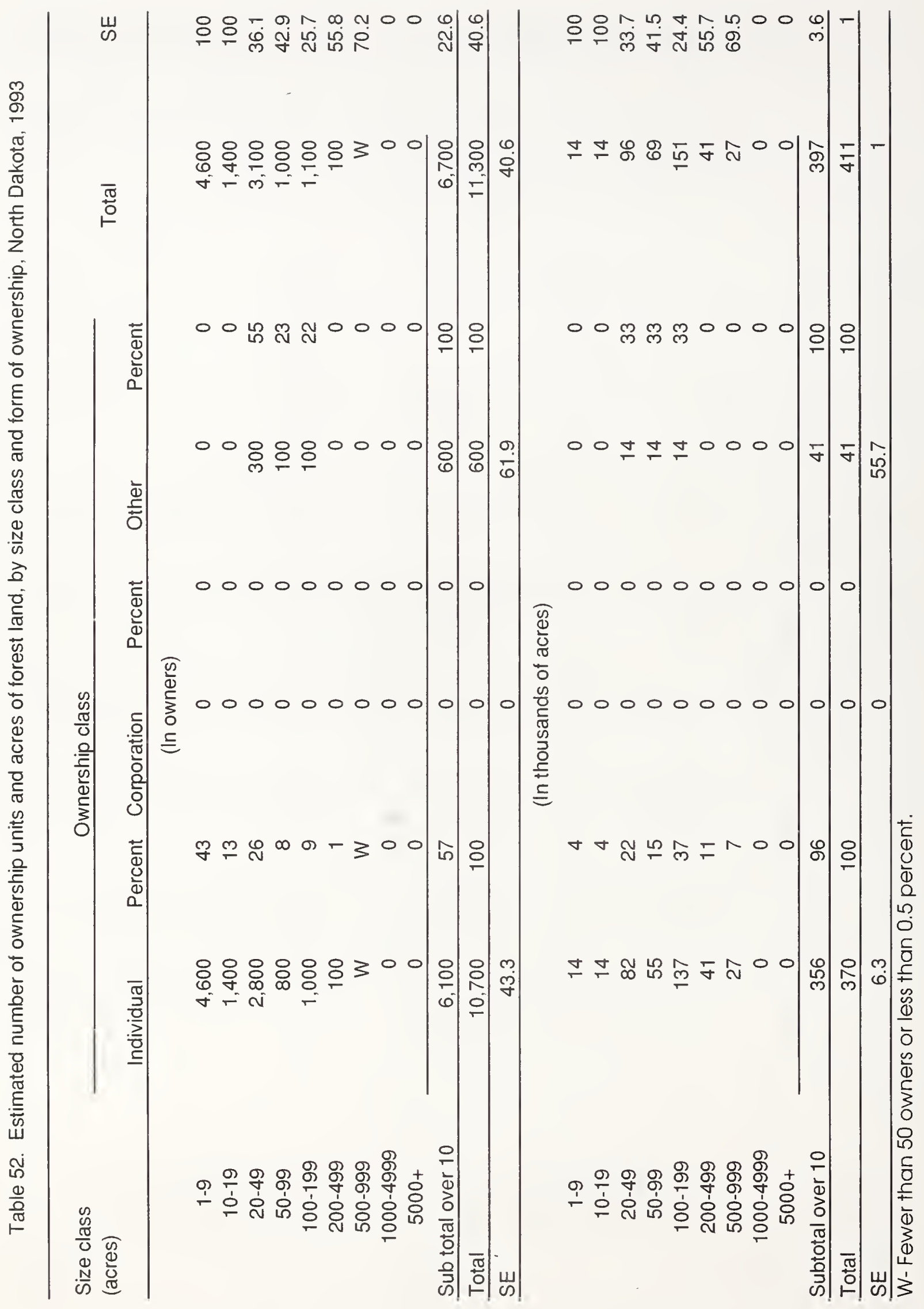


Table 53. Estimated number of ownership units and acres of forest land, by form of ownership and past harvest experience, North Dakota, 1993

\begin{tabular}{|c|c|c|c|c|c|c|}
\hline \multirow[t]{2}{*}{ Form of ownership } & \multicolumn{4}{|c|}{ Harvest experience } & \multirow{2}{*}{ Total } & \multirow[b]{2}{*}{ SE } \\
\hline & Harvested & Percent & Did not harvest & Percent & & \\
\hline \multicolumn{7}{|c|}{ (In owners) } \\
\hline Individual + joint & 2,300 & 79 & 8,400 & 100 & 10,700 & 43.3 \\
\hline Partnership & 600 & 21 & 0 & 0 & 600 & 61.9 \\
\hline Other & 0 & 0 & 0 & 0 & 0 & 0 \\
\hline Total & 2,900 & 100 & 8,400 & 100 & 11,300 & 40.6 \\
\hline SE & 23.4 & & 56.4 & & 40.6 & \\
\hline \multicolumn{7}{|c|}{ (In thousands of acres) } \\
\hline Individual + joint & 192 & 82 & 178 & 100 & 370 & 6.3 \\
\hline Partnership & 41 & 18 & 0 & 0 & 41 & 55.7 \\
\hline Other & 0 & 0 & 0 & 0 & 0 & 0 \\
\hline Total & 233 & 100 & 178 & 100 & 411 & 1 \\
\hline SE & 16.3 & & 21.3 & & 1 & \\
\hline
\end{tabular}


Table 54. Estimated number of ownership units and acres of forest land, by incorporated and unincorporated businesses and past harvest experience, North Dakota, 1993

\begin{tabular}{|c|c|c|c|c|c|c|}
\hline \multirow[t]{2}{*}{ Nature of business } & \multicolumn{4}{|c|}{ Harvest } & \multirow{2}{*}{ Total } & \multirow{2}{*}{ SE } \\
\hline & Harvested & Percent & Did not harvest & Percent & & \\
\hline \multicolumn{7}{|c|}{ (In owners) } \\
\hline \multicolumn{7}{|l|}{ Unincorporated: } \\
\hline Farm & 2,400 & 82 & 6,800 & 82 & 9,200 & 48.8 \\
\hline Misc. individual & 500 & 18 & 1,500 & 18 & 2,100 & 68.3 \\
\hline Total noncorporate & 2,900 & 100 & 8,400 & 100 & 11,300 & 40.6 \\
\hline Total & 2,900 & 100 & 8,400 & 100 & 11,300 & 40.6 \\
\hline $\mathrm{SE}$ & 23.4 & & 56.4 & & 40.6 & \\
\hline \multicolumn{7}{|c|}{ (In thousands of acres) } \\
\hline \multicolumn{7}{|l|}{ Unincorporated: } \\
\hline Farm & 205 & 88 & 137 & 77 & 343 & 8.4 \\
\hline Misc. individual & 27 & 12 & 41 & 23 & 69 & 41.5 \\
\hline Total noncorporate & 233 & 100 & 178 & 100 & 411 & 1 \\
\hline Total & 233 & 100 & 178 & 100 & 411 & 1 \\
\hline SE & 16.3 & & 21.3 & & 1 & \\
\hline
\end{tabular}

W- Fewer than 50 owners or less than 0.5 percent 


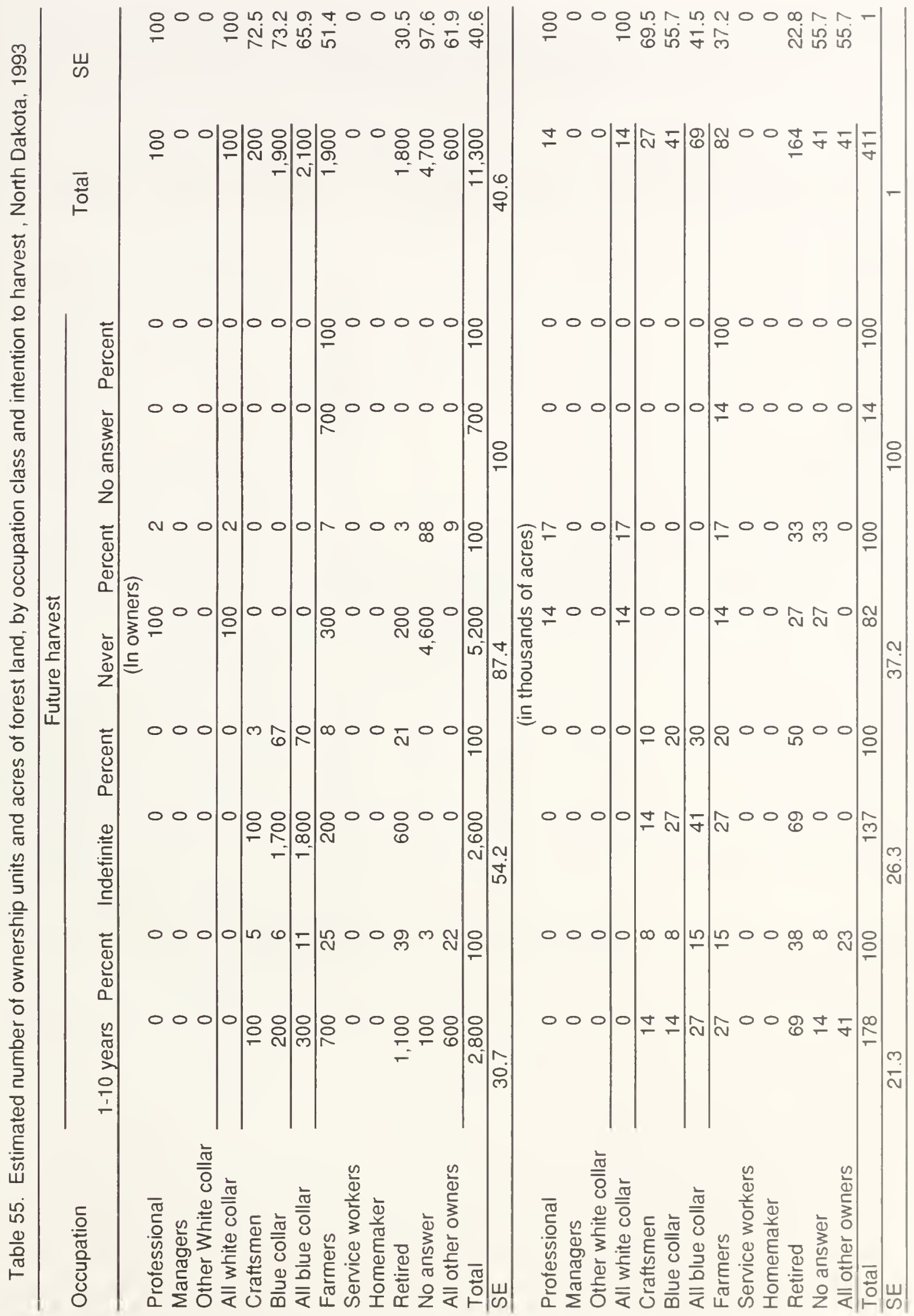


Table 56. Estimated number of ownership units and acres of forest land, by age class and past harvest experience, North Dakota, 1993

\begin{tabular}{|c|c|c|c|c|c|c|}
\hline \multirow[t]{2}{*}{ Age } & \multicolumn{4}{|c|}{ Harvest experience } & \multirow{2}{*}{ Total } & \multirow{2}{*}{ SE } \\
\hline & Hanested & Percent & Did not harvest & Percent & & \\
\hline \multicolumn{7}{|c|}{ (In owners) } \\
\hline Under 25 & 0 & 0 & 0 & 0 & 0 & 0 \\
\hline $25-34$ & 0 & 0 & 0 & 0 & 0 & 0 \\
\hline $35-44$ & 0 & 0 & 5,900 & 71 & 5,900 & 79.5 \\
\hline $45-54$ & 600 & 21 & 0 & 0 & 600 & 73.5 \\
\hline $55-64$ & 300 & 10 & 100 & 1 & 400 & 58.6 \\
\hline 65 or over & 1,400 & 48 & 2,400 & 28 & 3,800 & 27 \\
\hline No answer & 0 & 0 & 0 & 0 & 0 & 0 \\
\hline All other owners & 600 & 21 & 0 & 0 & 600 & 61.9 \\
\hline Total & 2,900 & 100 & 8,400 & 100 & 11,300 & 40.6 \\
\hline SE & 23.4 & & 56.4 & & 40.6 & \\
\hline \multicolumn{7}{|c|}{ (In thousands of acres) } \\
\hline Under 25 & 0 & 0 & 0 & 0 & 0 & 0 \\
\hline $25-34$ & 0 & 0 & 0 & 0 & 0 & 0 \\
\hline $35-44$ & 0 & 0 & 27 & 15 & 27 & 69.5 \\
\hline $45-54$ & 27 & 12 & 0 & 0 & 27 & 69.5 \\
\hline $55-64$ & 27 & 12 & 14 & 8 & 41 & 55.7 \\
\hline 65 or over & 137 & 59 & 137 & 77 & 274 & 13.2 \\
\hline No answer & 0 & 0 & 0 & 0 & 0 & 0 \\
\hline All other owners & 41 & 19 & 0 & 0 & 41 & 55.7 \\
\hline Total & 233 & 100 & 178 & 100 & 411 & 1 \\
\hline SE & 16.3 & & 21.3 & & 1 & \\
\hline
\end{tabular}


Table 57. Estimated number of ownership units and acres of forest land, by date of aquisition and form of ownership, North Dakota, 1993

\begin{tabular}{|c|c|c|c|c|c|c|c|}
\hline \multirow[b]{2}{*}{$\begin{array}{c}\text { Date of } \\
\text { acquisition }\end{array}$} & \multicolumn{5}{|c|}{ Ownership class } & \multirow[b]{2}{*}{ Total } & \multirow[b]{2}{*}{ SE } \\
\hline & $\begin{array}{c}\text { Forest } \\
\text { industry }\end{array}$ & Farmer & $\begin{array}{l}\text { Miscellaneous: } \\
\text { Individual }\end{array}$ & Corporation & Other & & \\
\hline \multicolumn{8}{|c|}{ (In owners) } \\
\hline 1990-1994 & 0 & 0 & 0 & 0 & 0 & 0 & 0 \\
\hline $1980-1989$ & 0 & 0 & 1,400 & 0 & 0 & 1,400 & 100 \\
\hline $1970-1979$ & 0 & 700 & 100 & 0 & 0 & 800 & 51 \\
\hline $1960-1969$ & 0 & 800 & 500 & 0 & 0 & 1,300 & 43.6 \\
\hline $1950-1959$ & 0 & 600 & 0 & 0 & 0 & 600 & 49.3 \\
\hline $1940-1949$ & 0 & 4,900 & 0 & 0 & 0 & 4,900 & 93 \\
\hline $1901-1939$ & 0 & 700 & 100 & 0 & 0 & 800 & 60.1 \\
\hline Prior to 1900 & 0 & 100 & 0 & 0 & 0 & 100 & 100 \\
\hline No answer & 0 & 1,400 & 0 & 0 & 0 & 1,400 & 67.5 \\
\hline Total & 0 & 9,200 & 2,100 & 0 & 0 & 11,300 & 40.6 \\
\hline SE & 0 & 48.8 & 68.3 & 0 & 0 & 40.6 & \\
\hline \multicolumn{8}{|c|}{ (In thousands of acres) } \\
\hline $1990-1994$ & 0 & 0 & 0 & 0 & 0 & 0 & 0 \\
\hline $1980-1989$ & 0 & 0 & 14 & 0 & 0 & 14 & 100 \\
\hline $1970-1979$ & 0 & 41 & 14 & 0 & 0 & 55 & 47.4 \\
\hline $1960-1969$ & 0 & 55 & 27 & 0 & 0 & 82 & 37.2 \\
\hline $1950-1959$ & 0 & 82 & 0 & 0 & 0 & 82 & 37.2 \\
\hline $1940-1949$ & 0 & 69 & 0 & 0 & 0 & 69 & 41.5 \\
\hline $1901-1939$ & 0 & 41 & 14 & 0 & 0 & 55 & 47.4 \\
\hline Prior to 1900 & 0 & 14 & 0 & 0 & 0 & 14 & 100 \\
\hline No answer & 0 & 41 & 0 & 0 & 0 & 41 & 55.7 \\
\hline Total & 0 & 343 & 69 & 0 & 0 & 411 & 1 \\
\hline SE & 0 & 8.4 & 41.5 & 0 & 0 & 1 & \\
\hline
\end{tabular}


Table 58. Estimated number of ownership units and acres of forest land, by distance from tracts, North Dakota, 1993

\begin{tabular}{|c|c|c|c|c|}
\hline \multirow[t]{3}{*}{ Distance } & \multicolumn{3}{|c|}{ Tracts } & \multirow{3}{*}{ Total } \\
\hline & \multirow[b]{2}{*}{1 tract } & \multicolumn{2}{|c|}{ More than one tract } & \\
\hline & & Nearest tract & Farthest tract & \\
\hline \multicolumn{5}{|c|}{ (In owners) } \\
\hline Less than 1 mile & 8,200 & 700 & 400 & \\
\hline 2-5 miles & 100 & 0 & 200 & \\
\hline $6-15$ miles & 700 & 0 & W & \\
\hline $16-25$ miles & 0 & 0 & 0 & \\
\hline 26-50 miles & 0 & 100 & 100 & \\
\hline $51-100$ miles & 0 & 0 & 0 & \\
\hline More than 100 miles & 100 & 0 & 100 & \\
\hline No answer & 700 & 700 & 700 & \\
\hline Total & 9,800 & 1,500 & 1,500 & 11,300 \\
\hline \multicolumn{5}{|c|}{ (In thousands of acres) } \\
\hline Less than 1 mile & 178 & 110 & 55 & \\
\hline 2-5 miles & 14 & 0 & 27 & \\
\hline $6-15$ miles & 27 & 0 & 14 & \\
\hline $16-25$ miles & 0 & 0 & 0 & \\
\hline 26-50 miles & 0 & 14 & 14 & \\
\hline $51-100$ miles & 0 & 0 & 0 & \\
\hline More than 100 miles & 27 & 0 & 14 & \\
\hline No answer & 27 & 14 & 14 & \\
\hline Total & 274 & 137 & 137 & 411 \\
\hline
\end{tabular}

W-Fewer than 50 owners or less than 0.5 percent 
Table 59. Estimated number of ownership units and acres of forest land, by primary and secondary reason for owning forest land, North Dakota, 1993

\begin{tabular}{|c|c|c|c|c|}
\hline \multirow[t]{2}{*}{ Reason } & \multicolumn{2}{|c|}{ Primary reason } & \multicolumn{2}{|c|}{ Secondary reason } \\
\hline & Number & Percent & Number & Percent \\
\hline & \multicolumn{4}{|c|}{ (In owners) } \\
\hline Land investment & 0 & 0 & 0 & 0 \\
\hline Recreation & 200 & 2 & 700 & 6 \\
\hline Timber production & 0 & 0 & 0 & 0 \\
\hline Farm and domestic use & 6,300 & 56 & 200 & 2 \\
\hline Esthetic enjoyment & 100 & 1 & 1,900 & 17 \\
\hline Part of farm & 2,000 & 18 & 4,700 & 42 \\
\hline Part of residence & 2,300 & 20 & 100 & 1 \\
\hline Estate & 100 & 1 & 0 & 0 \\
\hline Other & 200 & 2 & 0 & 0 \\
\hline No secondary reason given & - & - & 3,600 & 32 \\
\hline No answer & 0 & 0 & 0 & 0 \\
\hline \multirow[t]{2}{*}{ Total } & 11,300 & 100 & 11,300 & 100 \\
\hline & \multicolumn{4}{|c|}{ (In thousands of acres) } \\
\hline Land investment & 0 & 0 & 0 & 0 \\
\hline Recreation & 27 & 7 & 41 & 10 \\
\hline Timber production & 0 & 0 & 0 & 0 \\
\hline Farm and domestic use & 123 & 30 & 41 & 10 \\
\hline Esthetic enjoyment & 14 & 3 & 55 & 13 \\
\hline Part of farm & 137 & 33 & 41 & 10 \\
\hline Part of residence & 69 & 17 & 14 & 4 \\
\hline Estate & 27 & 7 & 0 & 0 \\
\hline Other & 14 & 3 & 0 & 0 \\
\hline No secondary reason given & - & - & 219 & 53 \\
\hline No answer & 0 & 0 & 0 & 0 \\
\hline Total & 411 & 100 & 411 & 100 \\
\hline
\end{tabular}


Table 60. Estimated number of ownership units and acres of forest land, by primary benefit expected in the next 10 years and past harvest experience, North Dakota, 1993

\begin{tabular}{|c|c|c|c|c|c|c|}
\hline \multirow[t]{2}{*}{ Benefits expected } & \multicolumn{4}{|c|}{ Harvest Experience } & \multirow{2}{*}{ Total } & \multirow{2}{*}{ SE } \\
\hline & Harvested & Percent & Did not harvest & Percent & & \\
\hline \multicolumn{7}{|c|}{ (In owners) } \\
\hline Land value increase & 0 & 0 & W & W & W & 100 \\
\hline Recreation & 500 & 16 & 100 & 1 & 600 & 66.1 \\
\hline Income from timber & 0 & 0 & 0 & 0 & 0 & 0 \\
\hline Farm and domestic us $\epsilon$ & 700 & 23 & 5,800 & 69 & 6,500 & 70.5 \\
\hline Esthetic enjoyment & 900 & 29 & 1,500 & 18 & 2,400 & 58.9 \\
\hline Firewood & 600 & 19 & 200 & 2 & 700 & 54 \\
\hline Other & 300 & 12 & 0 & 0 & 300 & 100 \\
\hline No answer & 0 & 0 & 700 & 9 & 700 & 94.6 \\
\hline Total & 2,900 & 100 & 8,400 & 100 & 11,300 & 40.6 \\
\hline SE & 23.4 & & 56.4 & & 40.6 & \\
\hline \multicolumn{7}{|c|}{ (In thousands of acres) } \\
\hline Land value increase & 0 & 0 & 14 & 8 & 14 & 100 \\
\hline Recreation & 27 & 12 & 14 & 8 & 41 & 5.7 \\
\hline Income from timber & 0 & 0 & 0 & 0 & 0 & 0 \\
\hline Farm and domestic use & 96 & 41 & 69 & 38 & 164 & 22.8 \\
\hline Esthetic enjoyment & 55 & 23 & 41 & 23 & 96 & 33.7 \\
\hline Firewood & 41 & 18 & 14 & 8 & 55 & 47.4 \\
\hline Other & 14 & 6 & 0 & 0 & 14 & 100 \\
\hline No answer & 0 & 0 & 27 & 15 & 27 & 69.5 \\
\hline Total & 233 & 100 & 178 & 100 & 411 & 1 \\
\hline SE & 16.3 & & 21.3 & & 1 & \\
\hline
\end{tabular}

W-Fewer than 50 owners or less than 0.5 percent. 


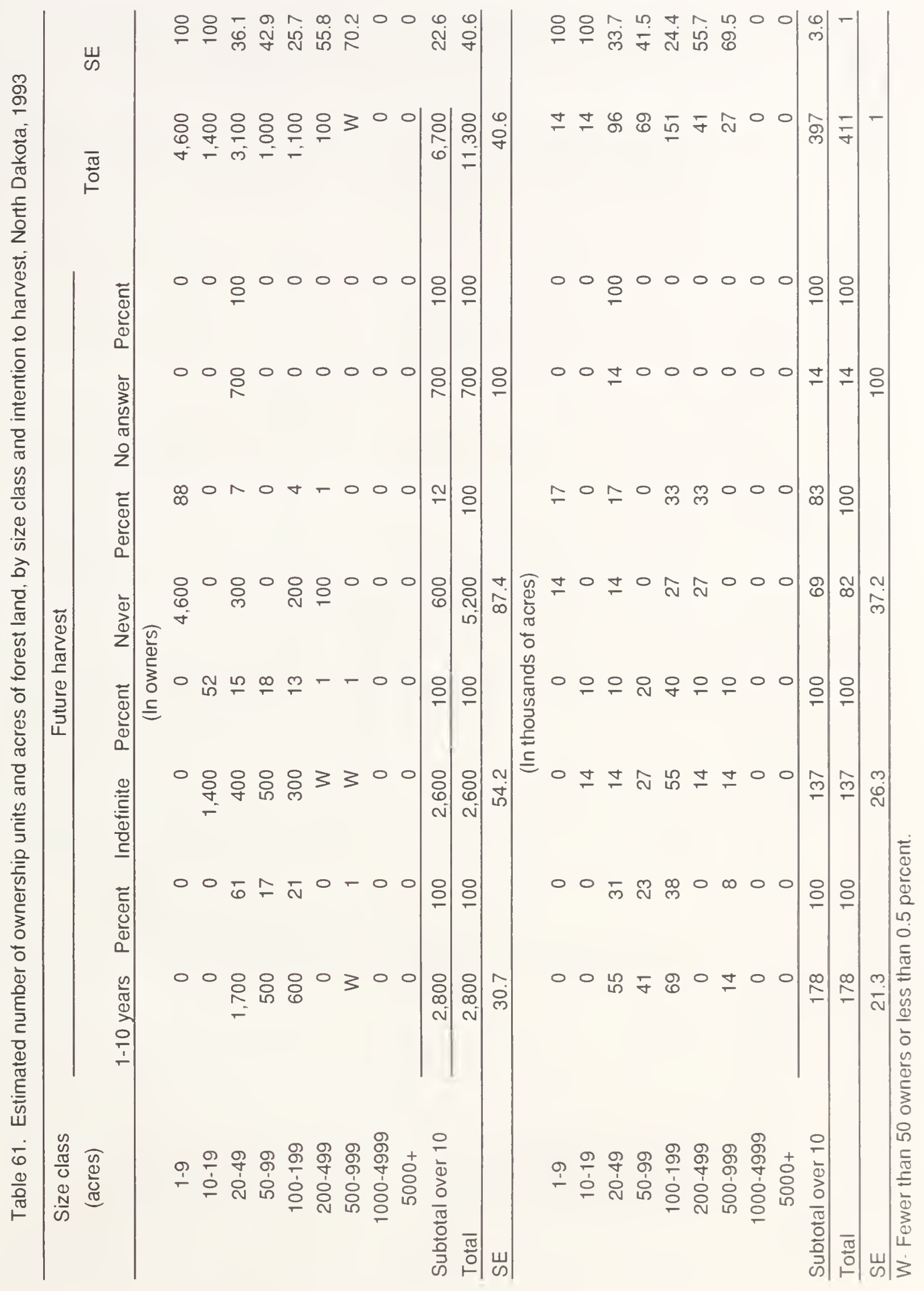




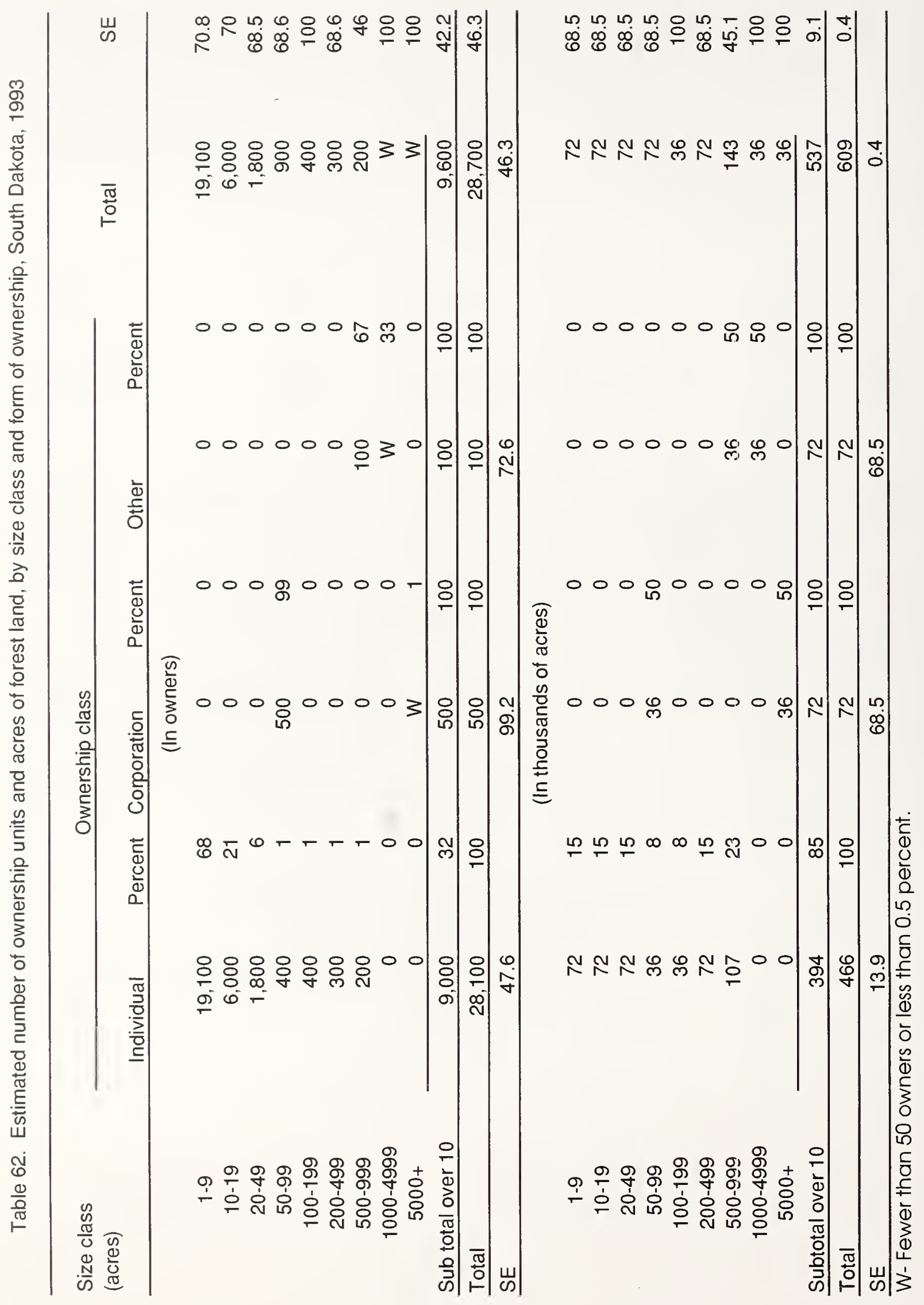


Table 63. Estimated number of ownership units and acres of forest land, by form of ownership and past harvest experience, South Dakota, 1993

\begin{tabular}{|c|c|c|c|c|c|c|}
\hline \multirow{2}{*}{ Form of ownership } & \multicolumn{4}{|c|}{ Harvest experience } & \multirow{2}{*}{ Total } & \multirow{2}{*}{ SE } \\
\hline & Harvested & Percent & Did not harvest & Percent & & \\
\hline \multicolumn{7}{|c|}{ (In owners) } \\
\hline Individual + joint & 1,300 & 68 & 26,800 & 100 & 28,100 & 47.6 \\
\hline Partnership & W & 2 & 0 & 0 & W & 100 \\
\hline Corporation & 500 & 26 & 0 & 0 & 500 & 99.2 \\
\hline Other & 100 & 4 & 0 & 0 & 100 & 100 \\
\hline Total & 1,900 & 100 & 26,800 & 100 & 28,700 & 46.3 \\
\hline SE & 50.6 & & 50.4 & & 46.3 & \\
\hline \multicolumn{7}{|c|}{ (In thousands of acres) } \\
\hline Individual + joint & 215 & 60 & 251 & 100 & 466 & 13.9 \\
\hline Partnership & 36 & 10 & 0 & 0 & 36 & 100 \\
\hline Corporation & 72 & 20 & 0 & 0 & 72 & 68.5 \\
\hline Other & 36 & 10 & 0 & 0 & 36 & 100 \\
\hline Total & 358 & 100 & 251 & 100 & 609 & 0.4 \\
\hline SE & 20.9 & & 29.9 & & 0.4 & \\
\hline
\end{tabular}

W-Fewer than 50 owners or less than 0.5 percent 
Table 64. Estimated number of ownership units and acres of forest land, by incorporated and unincorporated businesses and past harvest experience, South Dakota, 1993

\begin{tabular}{|c|c|c|c|c|c|c|}
\hline \multirow[t]{2}{*}{ Nature of business } & \multicolumn{4}{|c|}{ Harvest } & \multirow{2}{*}{ Total } & \multirow{2}{*}{ SE } \\
\hline & Harvested & Percent & Did not harvest & Percent & & \\
\hline \multicolumn{7}{|c|}{ (In owners) } \\
\hline \multicolumn{7}{|l|}{ Incorporated: } \\
\hline Forest industry & W & W & 0 & 0 & W & 100 \\
\hline Industrial business & 500 & 26 & 0 & 0 & 500 & 100 \\
\hline Other & 0 & 0 & 0 & 0 & 0 & 71.6 \\
\hline Total corporate & 500 & 26 & 0 & 0 & 500 & 99.2 \\
\hline \multicolumn{7}{|l|}{ Unincorporated: } \\
\hline Farm & 1,300 & 67 & 14,400 & 54 & 15,700 & 49.8 \\
\hline Misc. individual & 100 & 7 & 12,400 & 46 & 12,500 & 95.1 \\
\hline Sport/ recreation club & 0 & 0 & 0 & 0 & 0 & 0 \\
\hline Total noncorporate & 1,400 & 74 & 26,800 & 100 & 28,200 & 47.4 \\
\hline Total & 1,900 & 100 & 26,800 & 100 & 28,700 & 46.3 \\
\hline SE & 50.6 & & 50.4 & & 46.3 & \\
\hline \multicolumn{7}{|c|}{ (In thousands of acres) } \\
\hline Incorporated: & & & & & & \\
\hline Forest industry & 36 & 10 & 0 & 0 & 36 & 100 \\
\hline Industrial business & 36 & 10 & 0 & 0 & 36 & 100 \\
\hline Other & 0 & 0 & 0 & 0 & 0 & 0 \\
\hline Total corporate & 72 & 20 & 0 & 0 & 72 & 68.5 \\
\hline \multicolumn{7}{|l|}{ Unincorporated: } \\
\hline Farm & 251 & 70 & 179 & 71 & 430 & 16.1 \\
\hline Misc. individual & 36 & 10 & 72 & 29 & 107 & 54 \\
\hline Sport/ recreation club & 0 & 0 & 0 & 0 & 0 & $c$ \\
\hline Total noncorporate & 287 & 80 & 251 & 100 & 537 & 9.1 \\
\hline Total & 358 & 100 & 251 & 100 & 609 & 0.4 \\
\hline SE & 20.9 & & 29.9 & & 0.4 & \\
\hline
\end{tabular}

W- Fewer than 50 owners or less than 0.5 percent 


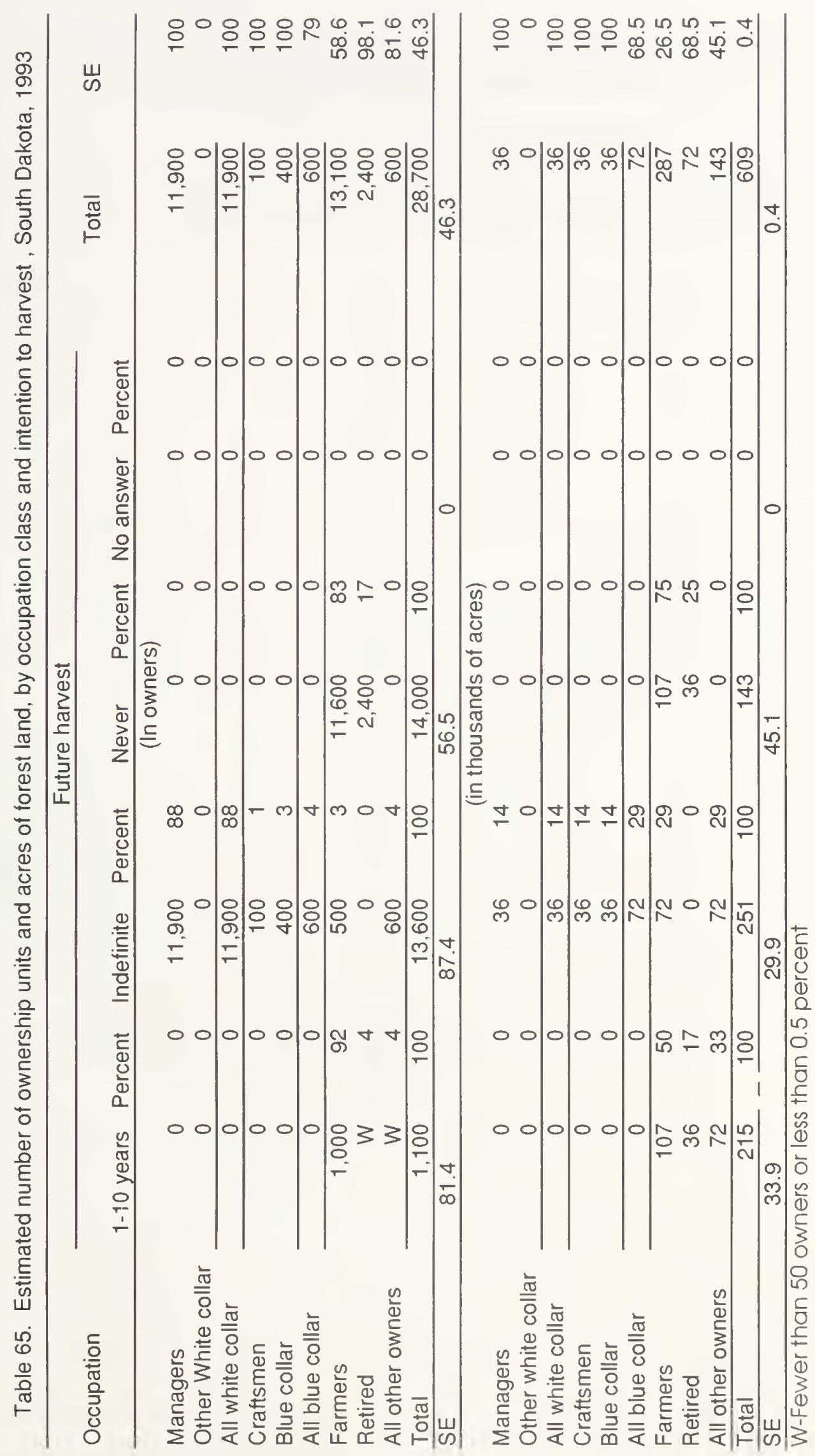


Table 66. Estimated number of ownership units and acres of forest land, by age class and past harvest experience, South Dakota, 1993

\begin{tabular}{|c|c|c|c|c|c|c|}
\hline \multirow[t]{2}{*}{ Age } & \multicolumn{4}{|c|}{ Harvest experience } & \multirow{2}{*}{ Total } & \multirow{2}{*}{ SE } \\
\hline & Harvested & Percent & Did not harvest & Percent & & \\
\hline \multicolumn{7}{|c|}{ (In owners) } \\
\hline Under 25 & 0 & 0 & 0 & 0 & 0 & 0 \\
\hline $25-34$ & 0 & 0 & 0 & 0 & 0 & 0 \\
\hline $35-44$ & 0 & 0 & 0 & 0 & 0 & 0 \\
\hline $45-54$ & 400 & 19 & 16,000 & 60 & 16,300 & 74.7 \\
\hline $55-64$ & 0 & 0 & 0 & 0 & 0 & 0 \\
\hline 65 or over & 900 & 49 & 10,800 & 40 & 11,700 & 62.5 \\
\hline No answer & 0 & 0 & 0 & 0 & 0 & 0 \\
\hline All other owners & 600 & 32 & 0 & 0 & 600 & 81.6 \\
\hline Total & 1,900 & 100 & 26,800 & 100 & 28,700 & 46.3 \\
\hline SE & 50.6 & & 50.4 & & 46.3 & \\
\hline \multicolumn{7}{|c|}{ (In thousands of acres) } \\
\hline Under 25 & 0 & 0 & 0 & 0 & 0 & 0 \\
\hline $25-34$ & 0 & 0 & 0 & 0 & 0 & 0 \\
\hline $35-44$ & 0 & 0 & 0 & 0 & 0 & 0 \\
\hline $45-54$ & 143 & 40 & 107 & 43 & 251 & 29.9 \\
\hline $55-64$ & 0 & 0 & 0 & 0 & 0 & 0 \\
\hline 65 or over & 72 & 20 & 143 & 57 & 215 & 33.9 \\
\hline No answer & 0 & 0 & 0 & 0 & 0 & 0 \\
\hline All other owners & 143 & 40 & 0 & 0 & 143 & 45.1 \\
\hline Total & 358 & 100 & 251 & 100 & 609 & 0.4 \\
\hline SE & 20.9 & & 29.9 & & 0.4 & \\
\hline
\end{tabular}


Table 67. Estimated number of ownership units and acres of forest land, by date of aquisition and form of ownership, South Dakota, 1993

\begin{tabular}{|c|c|c|c|c|c|c|c|}
\hline \multirow[b]{2}{*}{$\begin{array}{c}\text { Date of } \\
\text { acquisition }\end{array}$} & \multicolumn{5}{|c|}{ Ownership class } & \multirow[b]{2}{*}{ Total } & \multirow[b]{2}{*}{ SE } \\
\hline & $\begin{array}{c}\text { Forest } \\
\text { industry }\end{array}$ & Farmer & $\begin{array}{c}\text { Miscellaneous: } \\
\text { Individual }\end{array}$ & Corporation & Other & & \\
\hline \multicolumn{8}{|c|}{ (In owners) } \\
\hline 1990-1994 & 0 & 0 & 0 & 0 & 0 & 0 & 0 \\
\hline $1980-1989$ & 0 & 7,300 & 400 & 500 & 0 & 8,200 & 86.6 \\
\hline $1970-1979$ & 0 & 900 & 12,100 & 0 & 0 & 13,000 & 91.8 \\
\hline $1960-1969$ & 0 & 0 & 0 & 0 & 0 & 0 & 0 \\
\hline $1950-1959$ & 0 & 3,800 & 0 & 0 & 0 & 3,800 & 94 \\
\hline $1940-1949$ & 0 & 3,700 & 0 & 0 & 0 & 3,700 & 67 \\
\hline $1901-1939$ & 0 & 0 & 0 & 0 & 0 & 0 & 0 \\
\hline Prior to 1900 & W & 0 & 0 & 0 & 0 & W & 100 \\
\hline No answer & 0 & 0 & 0 & 0 & 0 & 0 & 0 \\
\hline Total & $W$ & 15,700 & 12,500 & 500 & 0 & 28,700 & 46.3 \\
\hline SE & 100 & 49.8 & 95.1 & 100 & 0 & 46.3 & \\
\hline \multicolumn{8}{|c|}{ (In thousands of acres) } \\
\hline $1990-1994$ & 0 & 0 & 0 & 0 & 0 & 9 & $\mathrm{~g}$ \\
\hline $1980-1989$ & 0 & 107 & 36 & 36 & 0 & 179 & 38.7 \\
\hline $1970-1979$ & 0 & 36 & 72 & 0 & 0 & 107 & 54 \\
\hline $1960-1969$ & 0 & 0 & 0 & 0 & 0 & 0 & 0 \\
\hline $1950-1959$ & 0 & 143 & 0 & 0 & 0 & 143 & 45.1 \\
\hline $1940-1949$ & 0 & 143 & 0 & 0 & 0 & 143 & 45.1 \\
\hline $1901-1939$ & 0 & 0 & 0 & 0 & 0 & 0 & 0 \\
\hline Prior to 1900 & 36 & 0 & 0 & 0 & 0 & 36 & 100 \\
\hline No answer & 0 & 0 & 0 & 0 & 0 & 0 & 0 \\
\hline Total & 36 & 430 & 107 & 36 & 0 & 609 & 0.4 \\
\hline SE & 100 & 16.1 & 54 & 100 & 0 & 0.4 & \\
\hline
\end{tabular}

W-Fewer than 50 owners or less than 0.5 percent 
Table 68. Estimated number of ownership units and acres of forest land, by distance from tracts, South Dakota, 1993

\begin{tabular}{|c|c|c|c|c|}
\hline \multirow{3}{*}{ Distance } & \multicolumn{3}{|c|}{ Tracts } & \multirow{3}{*}{ Total } \\
\hline & \multirow[b]{2}{*}{1 tract } & \multicolumn{2}{|c|}{ More than one tract } & \\
\hline & & Nearest tract & Farthest tract & \\
\hline \multicolumn{5}{|c|}{ (In owners) } \\
\hline Less than 1 mile & 16,300 & 4,300 & 200 & \\
\hline 2-5 miles & 0 & 0 & 500 & \\
\hline $6-15$ miles & 7,200 & 0 & 3,600 & \\
\hline 16-25 miles & 0 & 0 & 0 & \\
\hline 26-50 miles & 0 & 0 & $W$ & \\
\hline $51-100$ miles & 0 & 0 & 0 & \\
\hline More than 100 miles & 900 & 0 & 0 & \\
\hline No answer & 0 & 0 & 0 & \\
\hline Total & 24,400 & 4,300 & 4,300 & 28,700 \\
\hline \multicolumn{5}{|c|}{ (In thousands of acres) } \\
\hline Less than 1 mile & 215 & 287 & 107 & \\
\hline $2-5$ miles & 0 & 0 & 107 & \\
\hline $6-15$ miles & 36 & 0 & 36 & \\
\hline 16-25 miles & 0 & 0 & 0 & \\
\hline $26-50$ miles & 0 & 0 & 36 & \\
\hline $51-100$ miles & 0 & 0 & 0 & \\
\hline More than 100 miles & 72 & 0 & 0 & \\
\hline No answer & 0 & 0 & 0 & \\
\hline Total & 322 & 287 & 287 & 609 \\
\hline
\end{tabular}

W-fewer than 50 owners or less than 0.5 percent 
Table 69. Estimated number of ownership units and acres of forest land, by primary and secondary reason for owning forest land, South Dakota, 1993

\begin{tabular}{|c|c|c|c|c|}
\hline \multirow[t]{2}{*}{ Reason } & \multicolumn{2}{|l|}{ Primary reason } & \multicolumn{2}{|c|}{ Secondary reason } \\
\hline & Number & Percent & Number & Percent \\
\hline & \multicolumn{4}{|c|}{ (In owners) } \\
\hline Land investment & 100 & W & W & W \\
\hline Recreation & 3,600 & 13 & 100 & W \\
\hline Timber production & W & W & 700 & 2 \\
\hline Farm and domestic use & 9,600 & 33 & 36,000 & 13 \\
\hline Esthetic enjoyment & 0 & 0 & 500 & 2 \\
\hline Part of farm & 2,400 & 8 & 100 & W \\
\hline Part of residence & 11,900 & 42 & 2,500 & 9 \\
\hline Estate & 0 & 0 & 0 & 0 \\
\hline Other & 1,000 & 4 & 0 & 0 \\
\hline No secondary reason given & - & - & 21,300 & 74 \\
\hline No answer & 0 & $\underline{0}$ & 0 & 0 \\
\hline \multirow[t]{2}{*}{ Total } & 28,700 & 100 & 28,700 & 100 \\
\hline & \multicolumn{4}{|c|}{ (In thousands of acres) } \\
\hline Land investment & 36 & 6 & 36 & 6 \\
\hline Recreation & 36 & 6 & 36 & 6 \\
\hline Timber production & 36 & 6 & 107 & 18 \\
\hline Farm and domestic use & 107 & 18 & 36 & 6 \\
\hline Esthetic enjoyment & 0 & 0 & 72 & 12 \\
\hline Part of farm & 251 & 41 & 36 & 6 \\
\hline Part of residence & 36 & 6 & 107 & 18 \\
\hline Estate & 0 & 0 & 0 & 0 \\
\hline Other & 107 & 18 & 0 & 0 \\
\hline No secondary reason given & - & - & 179 & 29 \\
\hline No answer & 0 & 0 & 0 & 0 \\
\hline Total & 609 & 100 & 609 & 100 \\
\hline
\end{tabular}

W-Fewer than 50 owners or less than 0.5 percent 
Table 70. Estimated number of ownership units and acres of forest land, by primary benefit expected in the next 10 years and past harvest experience, South Dakota, 1993

\begin{tabular}{|c|c|c|c|c|c|c|}
\hline \multirow[t]{2}{*}{ Benefits expected } & \multicolumn{4}{|c|}{ Harvest Experience } & \multirow{2}{*}{ Total } & \multirow{2}{*}{ SE } \\
\hline & Harvested & Percent & Did not harvest & Percent & & \\
\hline \multicolumn{7}{|c|}{ (In owners) } \\
\hline Land value increase & 100 & 6 & 400 & 1 & 500 & 77.6 \\
\hline Recreation & 100 & 7 & 0 & 0 & 100 & 100 \\
\hline Income from timber & 100 & 6 & 0 & 0 & 100 & 70.1 \\
\hline Farm and domestic us $\epsilon$ & 1,000 & 53 & 13,100 & 49 & 14,100 & 55.9 \\
\hline Esthetic enjoyment & W & 2 & 900 & 3 & 900 & 95.1 \\
\hline Firewood & 0 & 0 & 0 & 0 & 0 & 0 \\
\hline Other & 500 & 26 & 12,400 & 46 & 12,900 & 92.3 \\
\hline No answer & 0 & 0 & 0 & 0 & 0 & 0 \\
\hline Total & 1,900 & 100 & 26,800 & 100 & 28,700 & 46.3 \\
\hline SE & 50.6 & & 50.4 & & 46.3 & \\
\hline \multicolumn{7}{|c|}{ (In thousands of acres) } \\
\hline Land value increase & 36 & 10 & 36 & 14 & 72 & 68.5 \\
\hline Recreation & 36 & 10 & 0 & 0 & 36 & 100 \\
\hline Income from timber & 107 & 30 & 0 & 0 & 107 & 54 \\
\hline Farm and domestic us $\epsilon$ & 107 & 30 & 107 & 43 & 215 & 33.9 \\
\hline Esthetic enjoyment & 36 & 10 & 36 & 14 & 72 & 68.5 \\
\hline Firewood & 0 & 0 & 0 & 0 & 0 & 0 \\
\hline Other & 36 & 10 & 72 & 29 & 107 & 54 \\
\hline No answer & 0 & 0 & 0 & 0 & 0 & 0 \\
\hline Total & 358 & 100 & 251 & 100 & 609 & 0.4 \\
\hline SE & 20.9 & & 29.9 & & 0.4 & \\
\hline
\end{tabular}

W-Fewer than 50 owners or less than 0.5 percent. 


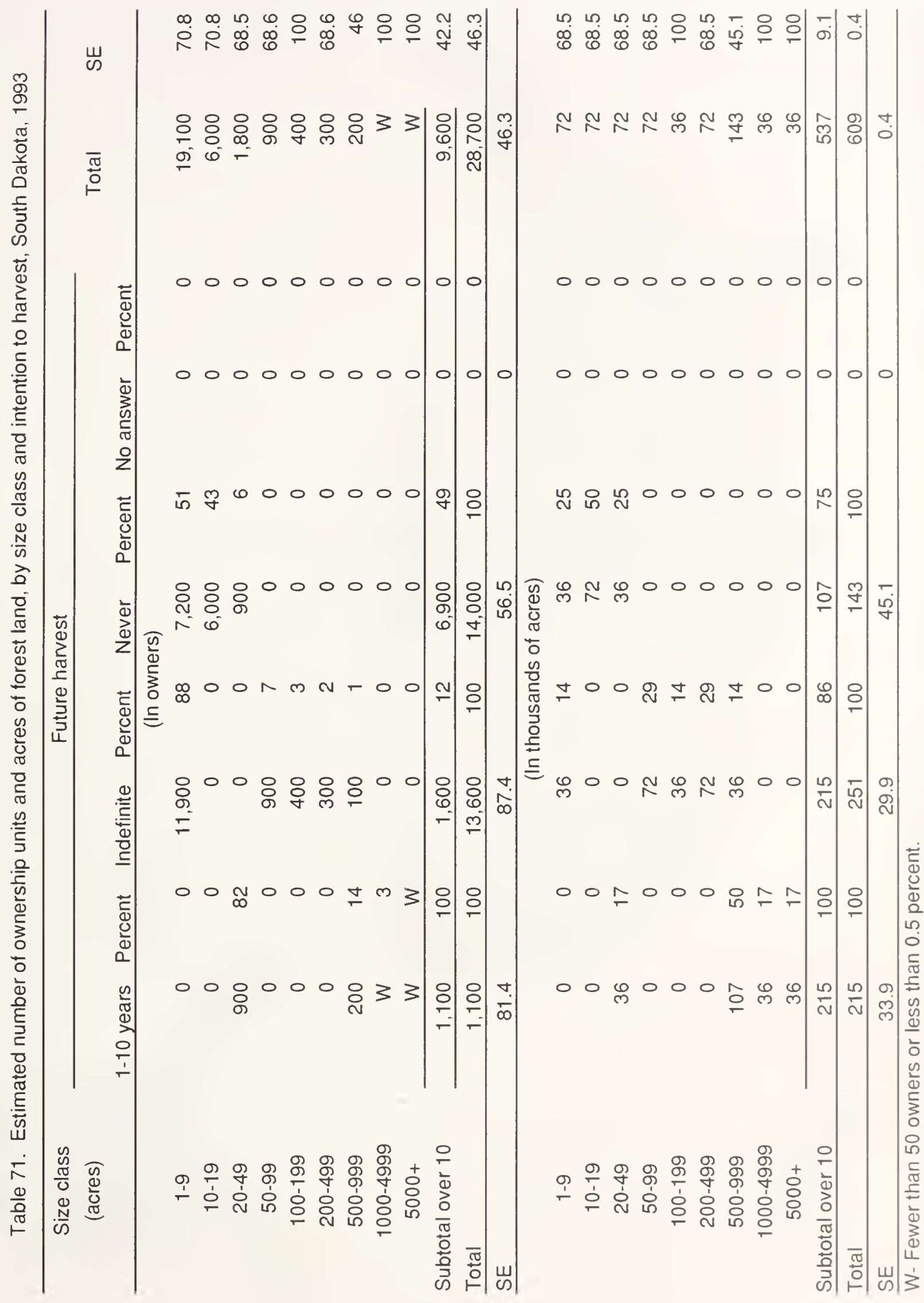




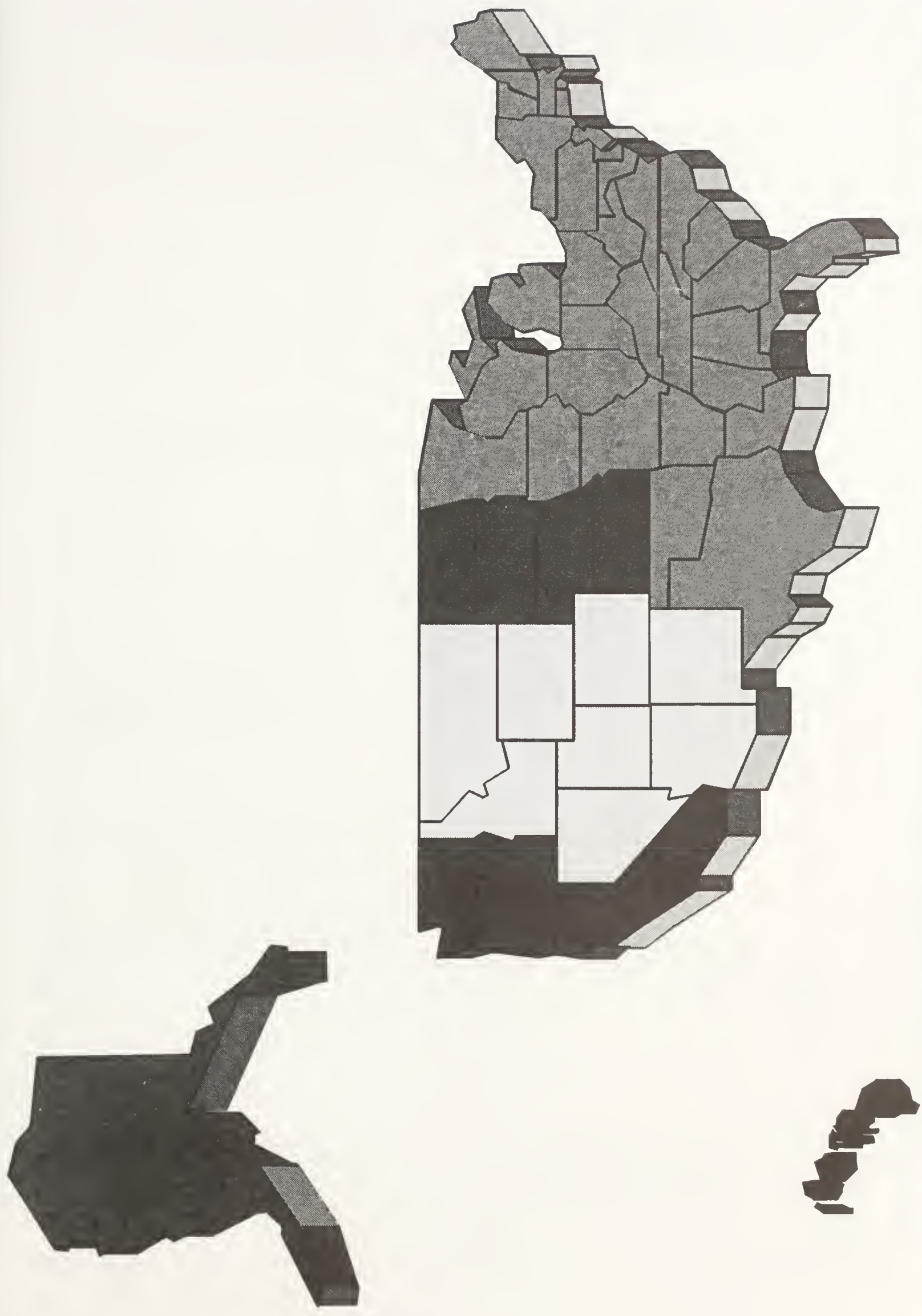


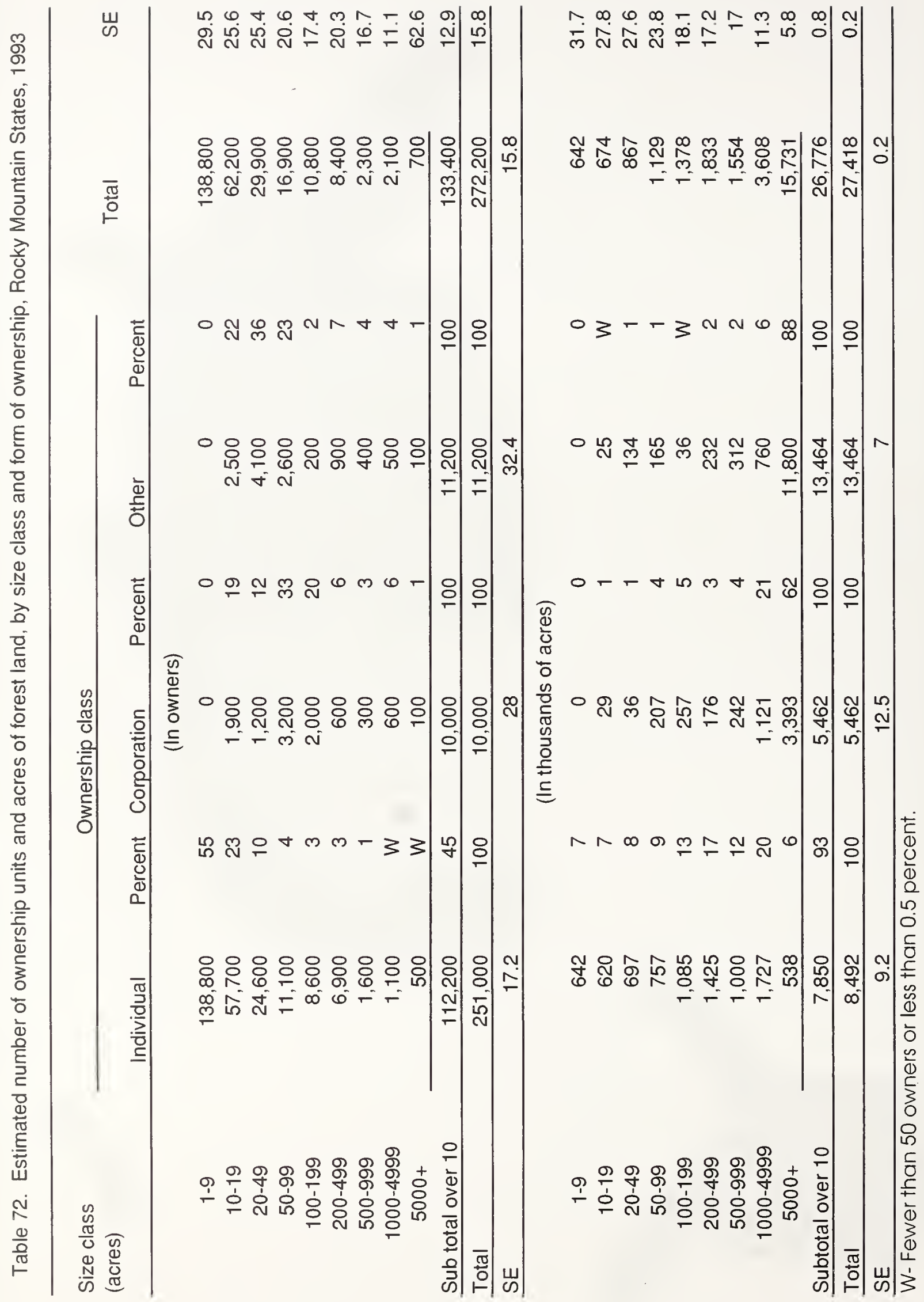


Table 73. Estimated number of ownership units and acres of forest land, by form of ownership and past harvest experiencs, Rocky Mountain States, 1993

Form of ownership

Harvest experience

Total

SE

Harvested Percent Did not harvest Percent

(In owners)

\begin{tabular}{|c|c|c|c|c|c|c|}
\hline Individual + joint & 96,800 & 95 & 154,200 & 90 & 251,000 & 17.2 \\
\hline Partnership & 900 & 1 & 8,600 & 5 & 9,400 & 36.3 \\
\hline Corporation & 3,700 & 4 & 6,200 & 4 & 10,000 & 28.3 \\
\hline Other & 100 & W & 1,700 & 1 & 1,800 & 70.4 \\
\hline Total & 101,500 & 100 & 170,600 & 100 & 272,200 & 15.8 \\
\hline SE & 24.7 & & 21.4 & & 15.8 & \\
\hline \multicolumn{7}{|c|}{ (In thousands of acres) } \\
\hline Individual + joint & 5,169 & 24 & 3,323 & 58 & 8,492 & 9.2 \\
\hline Partnership & 1,193 & 5 & 704 & 12 & 1,897 & 17 \\
\hline Corporation & 4,166 & 19 & 1,297 & 23 & 5.462 & 12.5 \\
\hline Other & 11,177 & 51 & 389 & 7 & 11,567 & 8.5 \\
\hline Total & 21,705 & 100 & 5,712 & 100 & 27,418 & 0.2 \\
\hline SE & 2.6 & & 10 & & 0.2 & \\
\hline
\end{tabular}

W-Fewer than 50 owners or less than 0.5 percent 
Table 74. Estimated number of ownership units and acres of forest land, by incorporated and unincorporated businesses and past harvest experience, Rocky Mountain States, 1993

\begin{tabular}{|c|c|c|c|c|c|c|}
\hline \multirow[t]{2}{*}{ Nature of business } & \multicolumn{4}{|c|}{ Harvest } & \multirow{2}{*}{ Total } & \multirow{2}{*}{ SE } \\
\hline & Harvested & Percent & Did not harvest & Percent & & \\
\hline \multicolumn{7}{|c|}{ (In owners) } \\
\hline \multicolumn{7}{|l|}{ Incorporated: } \\
\hline Forest industry & 100 & W & 0 & 0 & 100 & 81.2 \\
\hline Farm & 1,700 & 2 & 2,400 & 1 & 4,100 & 49 \\
\hline Industrial business & 100 & W & 1,000 & 1 & 1,100 & 67.2 \\
\hline Real estate & 300 & W & 1,300 & 1 & 1,700 & 62.1 \\
\hline Sport/ recreation club & 1,500 & 1 & 1,500 & 1 & 3,000 & 54 \\
\hline Other & 100 & W & W & W & 100 & 57.1 \\
\hline Total corporate & 3,700 & 4 & 6,200 & 4 & 10,000 & 28.3 \\
\hline \multicolumn{7}{|l|}{ Unincorporated: } \\
\hline Forest industry & W & W & 0 & 0 & W & 28.7 \\
\hline Farm & 20,900 & 21 & 43,000 & 25 & 63,900 & 21.5 \\
\hline Misc. individual & 76,700 & 75 & 113,900 & 67 & 190,600 & 21.8 \\
\hline Real estate & W & W & 1,900 & 1 & 1,900 & 69.6 \\
\hline Nonindustrial business & 0 & 0 & 100 & W & 100 & 70.1 \\
\hline Sport/ recreation club & 0 & 0 & 700 & W & 700 & 100 \\
\hline Other & 200 & W & 4,800 & 3 & 5,000 & 57.6 \\
\hline Total noncorporate & 97,800 & 96 & 164,400 & 96 & 262,200 & 16.4 \\
\hline Total & 101,500 & 100 & 170,600 & 100 & 272,200 & 15.8 \\
\hline SE & 24.7 & & 21.4 & & 15.8 & \\
\hline \multicolumn{7}{|c|}{ (In thousands of acres) } \\
\hline Incorporated: & & & & & & \\
\hline Forest industry & 1,491 & 7 & 0 & 0 & 1,491 & 33.6 \\
\hline Farm & 1,815 & 8 & 727 & 13 & 2,543 & 17.9 \\
\hline industrial business & 148 & 1 & 169 & 3 & 317 & 34.1 \\
\hline Real estate & 90 & W & 189 & 3 & 279 & 36 \\
\hline Sport/ recreation club & 329 & 1 & 183 & 3 & 512 & 40.7 \\
\hline Other & 292 & 1 & 29 & 1 & 320 & 72.4 \\
\hline Total corporate & 4,166 & 19 & 1,297 & 23 & 5,462 & 12.5 \\
\hline \multicolumn{7}{|l|}{ Unincorporated: } \\
\hline Forest industry & 7,933 & 37 & 0 & 0 & 7,933 & 19.5 \\
\hline Farm & 5,024 & 23 & 2,420 & 42 & 7,444 & 8.2 \\
\hline Misc. individual & 1,208 & 5 & 1,492 & 26 & 2,700 & 17 \\
\hline Real estate & 87 & W & 151 & 3 & 238 & 52.8 \\
\hline Nonindustrial business & 0 & 0 & 51 & 1 & 51 & 74.7 \\
\hline Sport/ recreation club & 0 & 0 & 29 & 1 & 29 & 100 \\
\hline Other & 3,288 & 15 & 273 & 5 & 3,561 & 33.3 \\
\hline Total noncorporate & 17,540 & 81 & 4,416 & 77 & 21,955 & 3.1 \\
\hline Total & 21,705 & 100 & 5,712 & 100 & 27,418 & 0.2 \\
\hline SE & 2.6 & & 10 & & 0.2 & \\
\hline
\end{tabular}

W- Fewer than 50 owners or less than 0.5 percent 


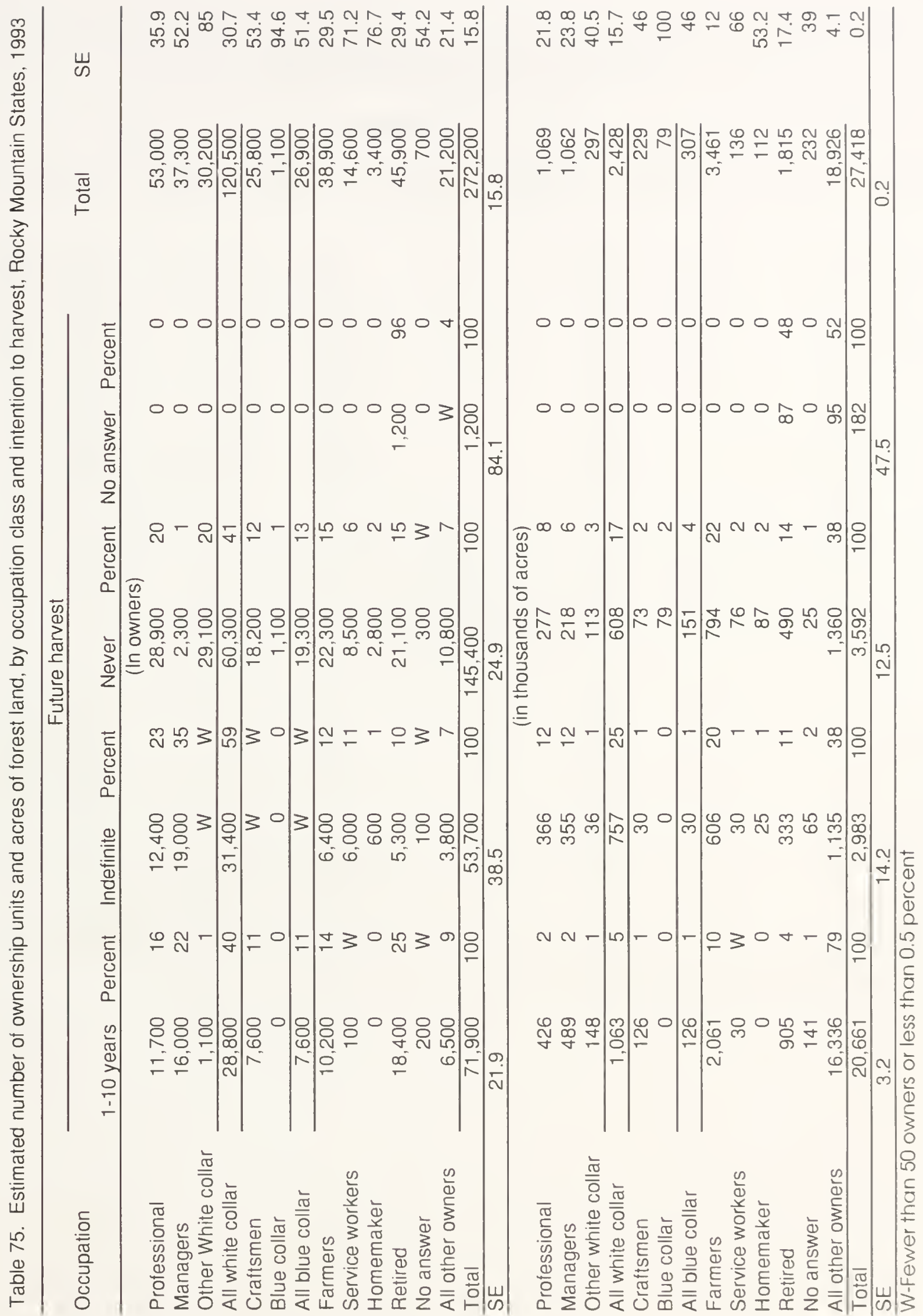


Table 76. Estimated number of ownership units and acres of forest land, by age class and past harvest experience, Rocky Mountain States, 1993

\begin{tabular}{|c|c|c|c|c|c|c|}
\hline \multirow[t]{2}{*}{ Age } & \multicolumn{4}{|c|}{ Harvest experience } & \multirow{2}{*}{ Total } & \multirow{2}{*}{ SE } \\
\hline & Harvested & Percent & Did not harvest & Percent & & \\
\hline \multicolumn{7}{|c|}{ (In owners) } \\
\hline Under 25 & 600 & 1 & 0 & 0 & 600 & 98.6 \\
\hline $25-34$ & 200 & W & 400 & W & 600 & 68.7 \\
\hline $35-44$ & 23,200 & 23 & 40,700 & 24 & 63,900 & 32.4 \\
\hline $45-54$ & 19,900 & 19 & 25,800 & 15 & 45,700 & 44.9 \\
\hline $55-64$ & 30,500 & 30 & 57,000 & 33 & 87,500 & 35.7 \\
\hline 65 or over & 22,300 & 22 & 30,100 & 18 & 52,400 & 26.7 \\
\hline No answer & 200 & W & 100 & W & 300 & 62.5 \\
\hline All other owners & 4,700 & 5 & 16,500 & 10 & 21,200 & 21.4 \\
\hline Total & 101,500 & 100 & 170,600 & 100 & 272,200 & 15.8 \\
\hline SE & 24.7 & & 21.4 & & 15.8 & \\
\hline \multicolumn{7}{|c|}{ (In thousands of acres) } \\
\hline Under 25 & 76 & W & 0 & 0 & 76 & 80.2 \\
\hline $25-34$ & 135 & 1 & 25 & W & 160 & 57.8 \\
\hline $35-44$ & 630 & 3 & 381 & 7 & 1,012 & 23.4 \\
\hline $45-54$ & 656 & 3 & 876 & 15 & 1,532 & 17.4 \\
\hline $55-64$ & 1,365 & 6 & 1,042 & 18 & 2,407 & 14.8 \\
\hline 65 or over & 2,212 & 10 & 937 & 16 & 3,149 & 14 \\
\hline No answer & 93 & W & 62 & 1 & 156 & 45.4 \\
\hline All other owners & 16,536 & 76 & 2,390 & 42 & 18,926 & 4.1 \\
\hline Total & 21,705 & 100 & 5,712 & 100 & 27,418 & 0.2 \\
\hline SE & 2.6 & & 10 & & 0.2 & \\
\hline
\end{tabular}

W-Fewer than 50 owners of less than 0.5 percent 
Table 77. Estimated number of ownership units and acres of forest land, by date of aquisition and form of ownership, Rocky Mountain States, 1993

\begin{tabular}{|c|c|c|c|c|c|c|c|}
\hline \multirow[b]{2}{*}{$\begin{array}{c}\text { Date of } \\
\text { acquisition }\end{array}$} & \multicolumn{5}{|c|}{ Ownership class } & \multirow[b]{2}{*}{ Total } & \multirow[b]{2}{*}{ SE } \\
\hline & $\begin{array}{l}\text { Forest } \\
\text { industry }\end{array}$ & Farmer & $\begin{array}{c}\text { Miscellaneous: } \\
\text { Individual }\end{array}$ & Corporation & Other & & \\
\hline & \multicolumn{4}{|c|}{ (In owners) } & & & \\
\hline $1990-1994$ & 0 & 7,000 & 43,200 & 1,300 & 200 & 51,700 & 35.8 \\
\hline 1980-1989 & W & 5,500 & 33,300 & 900 & 3,900 & 43,700 & 31.2 \\
\hline $1970-1979$ & 0 & 16,800 & 90,900 & 1,500 & 600 & 109,900 & 32.7 \\
\hline $1960-1969$ & 100 & 15,400 & 4,100 & 1,600 & 1,400 & 22,500 & 29.2 \\
\hline $1950-1959$ & W & 8,100 & 3,200 & 100 & 1,300 & 12,600 & 48.3 \\
\hline $1940-1949$ & 0 & 6,700 & 4,200 & W & 400 & 11,300 & 39.9 \\
\hline $1901-1939$ & W & 2,100 & 10,900 & W & W & 13,100 & 71.4 \\
\hline Prior to 1900 & W & 200 & 0 & 300 & W & 500 & 57.1 \\
\hline No answer & 0 & 6,100 & 800 & 0 & 0 & 6,900 & 74.6 \\
\hline Total & 100 & 68,000 & 190,600 & 5,800 & 7,700 & 272.200 & 15.8 \\
\hline \multirow[t]{2}{*}{ SE } & 66.4 & 20.3 & 21.8 & 34.8 & 42.3 & 15.8 & \\
\hline & \multicolumn{4}{|c|}{ (In thousands of acres) } & & & \\
\hline 1990-1994 & 0 & 577 & 544 & 372 & 50 & 1,543 & 22.8 \\
\hline $1980-1989$ & 210 & 1,660 & 685 & 109 & 191 & 2,855 & 17.1 \\
\hline $1970-1979$ & 0 & 1,524 & 854 & 254 & 25 & 2,657 & 14.3 \\
\hline 1960-1969 & 76 & 1,743 & 262 & 309 & 102 & 2,493 & 14.8 \\
\hline $1950-1959$ & 153 & 1,110 & 50 & 172 & 50 & 1,536 & 18.1 \\
\hline $1940-1949$ & 0 & 1,132 & 163 & 73 & 73 & 1,440 & 19.5 \\
\hline 1901-1939 & 720 & 1,291 & 154 & 62 & 334 & 2,561 & 25.8 \\
\hline Prior to 1900 & 8,264 & 518 & 0 & 79 & 2,939 & 11,799 & 8.9 \\
\hline No answer & 0 & 433 & 73 & 0 & 28 & 533 & 30.1 \\
\hline Total & 9,424 & 9,987 & 2,787 & 1,429 & 3,792 & 27,418 & 0.2 \\
\hline SE & 16.9 & 8 & 17.1 & 23.5 & 31.9 & 0.2 & \\
\hline
\end{tabular}

W-fewer than 50 owners or less than 0.5 percent 
Table 78. Estimated number of ownership units and acres of forest land, by distance from tracts, Rocky Mountain States, 1993

\begin{tabular}{|c|c|c|c|c|}
\hline \multirow{3}{*}{ Distance } & \multicolumn{3}{|c|}{ Tracts } & \multirow{3}{*}{ Total } \\
\hline & \multirow[b]{2}{*}{1 tract } & \multicolumn{2}{|c|}{ More than one tract } & \\
\hline & & Nearest tract & Farthest tract & \\
\hline \multicolumn{5}{|c|}{ (In owners) } \\
\hline Less than 1 mile & 35,600 & 28,800 & 9,400 & \\
\hline 2-5 miles & 41,800 & 3,300 & 11,200 & \\
\hline $6-15$ miles & 9,700 & 5,700 & 5,300 & \\
\hline 16-25 miles & 1,700 & 2,200 & 200 & \\
\hline $26-50$ miles & 18,900 & 1,700 & 6,800 & \\
\hline $51-100$ miles & 28,200 & 2,300 & 2,600 & \\
\hline More than 100 miles & 65,200 & 16,100 & 24,700 & \\
\hline No answer & 10,600 & 300 & 400 & \\
\hline Total & 211,700 & 60,500 & 60,500 & 272,200 \\
\hline \multicolumn{5}{|c|}{ (In thousands of acres) } \\
\hline Less than 1 mile & 2,242 & 7,742 & 900 & \\
\hline $2-5$ miles & 517 & 903 & 1,093 & \\
\hline $6-15$ miles & 731 & 1,300 & 1,266 & \\
\hline 16-25 miles & 313 & 258 & 435 & \\
\hline $26-50$ miles & 513 & 985 & 1,604 & \\
\hline $51-100$ miles & 356 & 380 & 2,168 & \\
\hline More than 100 miles & 1,301 & 1,090 & 5,162 & \\
\hline No answer & 738 & 8,049 & 8,079 & \\
\hline Total & 6,711 & 20,707 & 20,707 & 27,418 \\
\hline
\end{tabular}


Table 79. Estimated number of ownership units and acres of forest land, by primary and secondary reason for owning forest land, Rocky Mountain States, 1993

\begin{tabular}{|c|c|c|c|c|}
\hline \multirow[t]{2}{*}{ Reason } & \multicolumn{2}{|c|}{ Primary reason } & \multicolumn{2}{|c|}{ Secondary reason } \\
\hline & Number & Percent & Number & Percent \\
\hline & \multicolumn{4}{|c|}{ (In owners) } \\
\hline Land investment & 12,800 & 5 & 9,300 & 4 \\
\hline Recreation & 44,500 & 16 & 32,900 & 12 \\
\hline Timber production & 400 & W & 11,000 & 4 \\
\hline Farm and domestic use & 18,000 & 7 & 14,300 & 5 \\
\hline Esthetic enjoyment & 67,300 & 25 & 12,900 & 5 \\
\hline Part of farm & 16,200 & 6 & 1,800 & 1 \\
\hline Part of residence & 43,300 & 16 & 34,500 & 13 \\
\hline Estate & 20,000 & 7 & 22,800 & 8 \\
\hline Other & 49,000 & 18 & 21,900 & 8 \\
\hline No secondary reason given & - & - & 110,100 & 40 \\
\hline No answer & 600 & W & 600 & W \\
\hline \multirow[t]{2}{*}{ Total } & 272,200 & 100 & 272,200 & 100 \\
\hline & \multicolumn{4}{|c|}{ (In thousands of acres) } \\
\hline Land investment & 1,157 & 4 & 1,372 & 5 \\
\hline Recreation & 2,486 & 9 & 2,986 & 11 \\
\hline Timber production & 4,986 & 18 & 2,702 & 10 \\
\hline Farm and domestic use & 6,436 & 23 & 1,214 & 4 \\
\hline Esthetic enjoyment & 1,426 & 5 & 981 & 4 \\
\hline Part of farm & 2,785 & 10 & 985 & 4 \\
\hline Part of residence & 1,249 & 5 & 747 & 3 \\
\hline Estate & 529 & 2 & 1,213 & 4 \\
\hline Other & 5,681 & 21 & 5,902 & 22 \\
\hline No secondary reason given & - & - & 8,633 & 31 \\
\hline No answer & 682 & 2 & 682 & 2 \\
\hline Total & 27,418 & 100 & 27.418 & 100 \\
\hline
\end{tabular}


Table 80. Estimated number of ownership units and acres of forest land, by primary benefit expected in the next 10 years and past harvest experience, Rocky Mountain States, 1993

\begin{tabular}{|c|c|c|c|c|c|c|}
\hline \multirow[t]{2}{*}{ Benefits expected } & \multicolumn{4}{|c|}{ Harvest Experience } & \multirow{2}{*}{ Total } & \multirow{2}{*}{ SE } \\
\hline & Harvested & Percent & Did not harvest & Percent & & \\
\hline \multicolumn{7}{|c|}{ (In owners) } \\
\hline Land value increase & 7,000 & 7 & 8,300 & 5 & 15,300 & 31.1 \\
\hline Recreation & 6,300 & 6 & 40,200 & 23 & 46,600 & 57.4 \\
\hline Income from timber & 1,900 & 2 & 300 & W & 2,200 & 42.6 \\
\hline Farm and domestic use & 10,000 & 10 & 13,400 & 8 & 23,400 & 31 \\
\hline Esthetic enjoyment & 42,900 & 42 & 64,100 & 37 & 107,000 & 25.8 \\
\hline Firewood & 800 & 1 & 100 & W & 900 & 74.6 \\
\hline Other & 31,900 & 31 & 31,800 & 19 & 63,600 & 31.3 \\
\hline No answer & 900 & 1 & 12,400 & 7 & 13,300 & 54.3 \\
\hline Total & 101,600 & 100 & 170,600 & 100 & 272,200 & 15.8 \\
\hline SE & 24.7 & & 21.4 & & 15.8 & \\
\hline \multicolumn{7}{|c|}{ (In thousands of acres) } \\
\hline Land value increase & 1,084 & 5 & 605 & 11 & 1,689 & 16.9 \\
\hline Recreation & 2,715 & 13 & 929 & 16 & 3,644 & 23.7 \\
\hline Income from timber & 4,874 & 22 & 163 & 3 & 5,037 & 25.4 \\
\hline Farm and domestic use & 6.823 & 31 & 932 & 16 & 7,755 & 26.2 \\
\hline Esthetic enjoyment & 1,346 & 6 & 1,462 & 26 & 2,809 & 16.4 \\
\hline Firewood & 134 & 1 & 29 & 1 & 163 & 48.6 \\
\hline Other & 4,124 & 19 & 1,231 & 21 & 5,356 & 22.6 \\
\hline No answer & 604 & 3 & 360 & 6 & 964 & 33.7 \\
\hline Total & 21,705 & 100 & 5,712 & 100 & 27,418 & 0.2 \\
\hline SE & 2.6 & & 10 & & 0.2 & \\
\hline
\end{tabular}




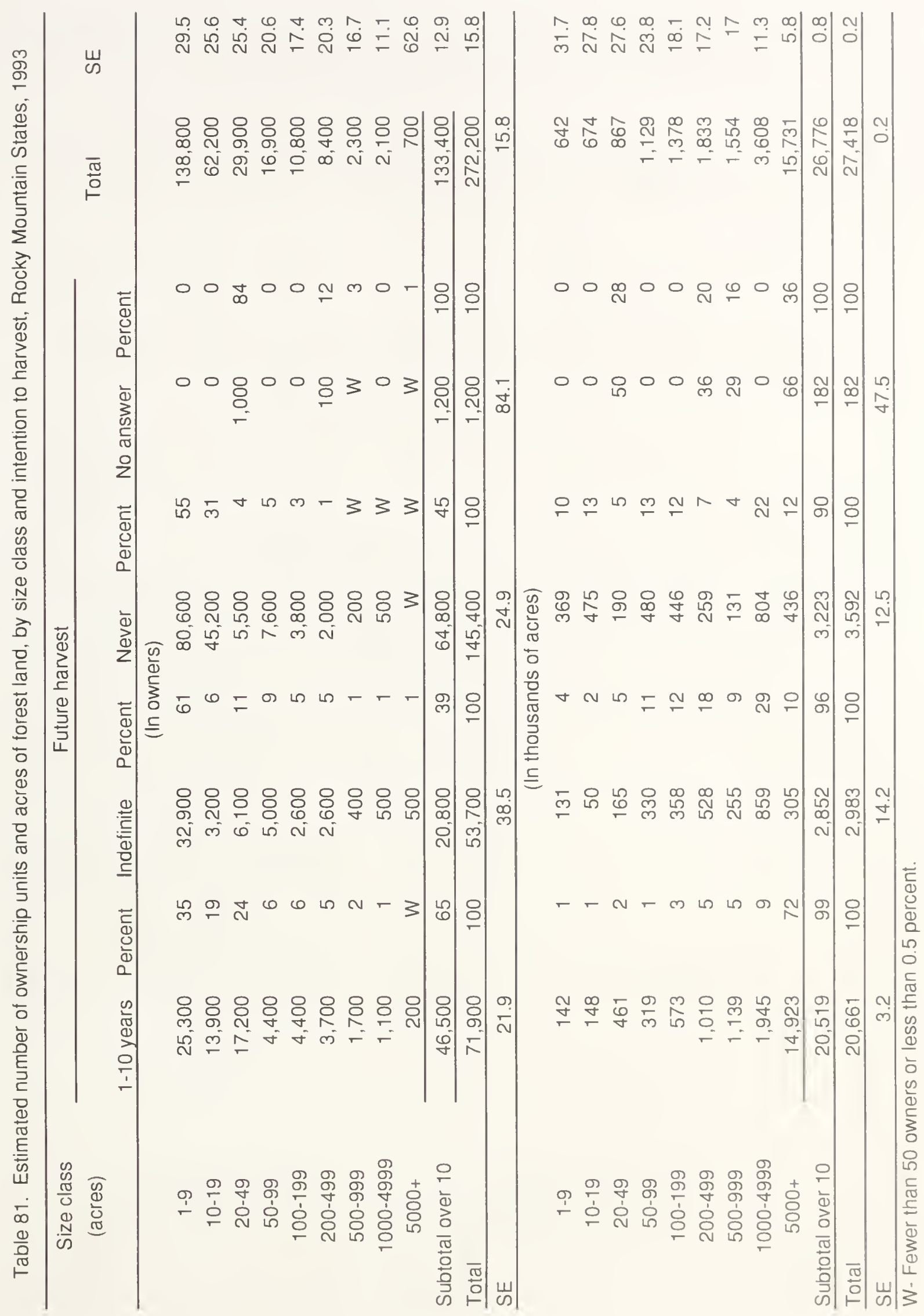




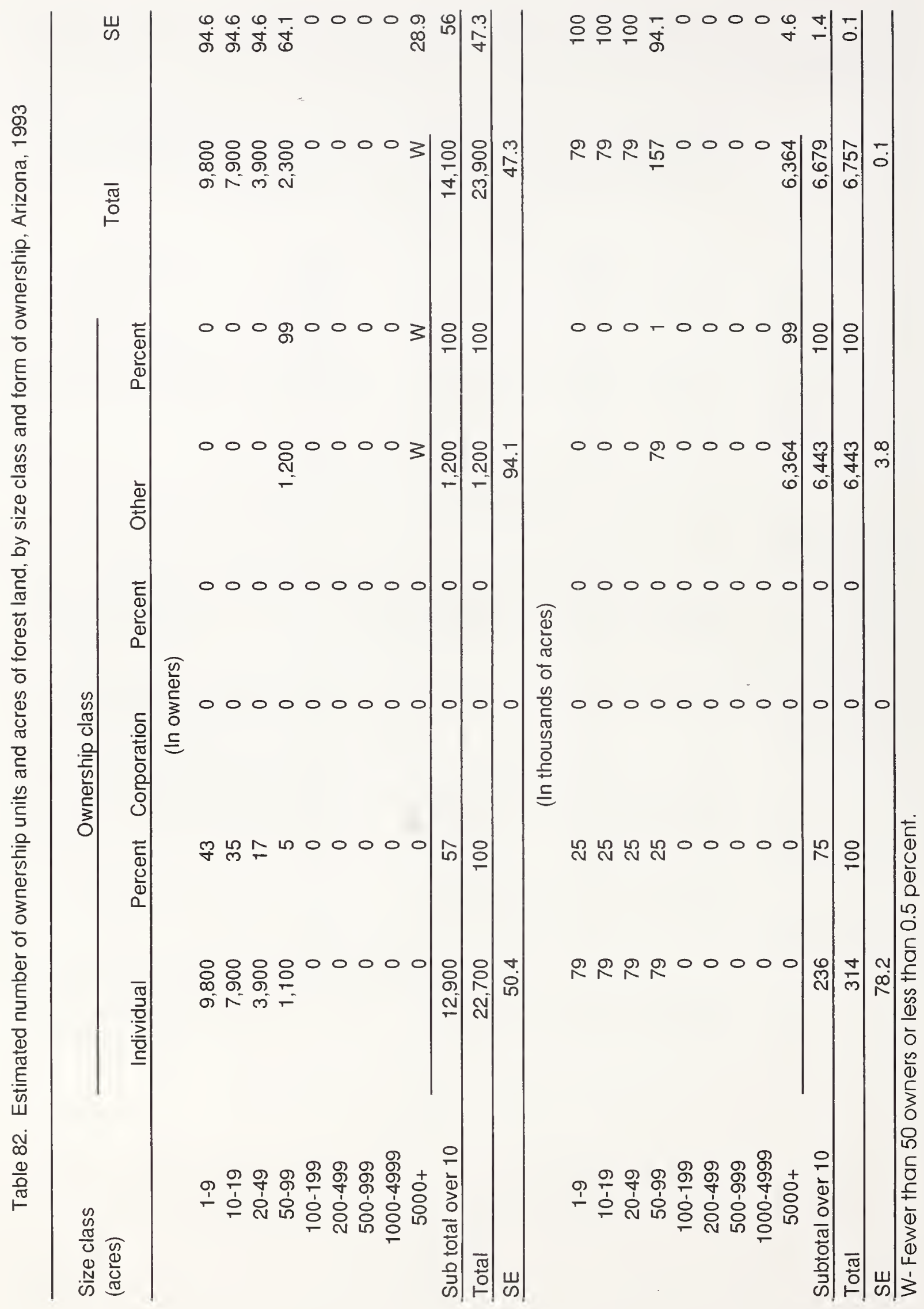


Table 83. Estimated number of ownership units and acres of forest land, by form of ownership and past harvest experience, Arizona, 1993

\begin{tabular}{|c|c|c|c|c|c|c|}
\hline \multirow[t]{2}{*}{ Form of ownership } & \multicolumn{4}{|c|}{ Harvest experience } & \multirow{2}{*}{ Total } & \multirow{2}{*}{ SE } \\
\hline & Harvested & Percent & Did not harvest & Percent & & \\
\hline \multicolumn{7}{|c|}{ (In owners) } \\
\hline Individual + joint & 3,900 & 100 & 18,800 & 94 & 22,700 & 50.4 \\
\hline Partnership & 0 & 0 & 1,200 & 6 & 1,200 & 94.6 \\
\hline Other & W & W & 0 & 0 & $W$ & 28.9 \\
\hline Total & 3,900 & 100 & 20,000 & 100 & 23,900 & 47.3 \\
\hline SE & 94.4 & & 56.2 & & 47.3 & \\
\hline \multicolumn{7}{|c|}{ (In thousands of acres) } \\
\hline Individual + joint & 79 & 1 & 236 & 75 & 314 & 78.2 \\
\hline Partnership & 0 & 0 & 79 & 25 & 79 & 100 \\
\hline Other & 6,364 & 99 & 0 & 0 & 6,364 & 4.6 \\
\hline Total & 6,443 & 100 & 314 & 100 & 6.757 & 0.1 \\
\hline SE & 3.8 & & 78.2 & & 0.1 & \\
\hline
\end{tabular}

W-Fewer than 50 owners or less than 0.5 percent 
Table 84. Estimated number of ownership units and acres of forest land, by incorporated and unincorporated businesses and past harvest experience, Arizona, 1993

\begin{tabular}{|c|c|c|c|c|c|c|}
\hline \multirow[t]{2}{*}{ Nature of business } & \multicolumn{4}{|c|}{ Harvest } & \multirow{2}{*}{ Total } & \multirow{2}{*}{ SE } \\
\hline & Harvested & Percent & Did not harvest & Percent & & \\
\hline \multicolumn{7}{|c|}{ (In owners) } \\
\hline \multicolumn{7}{|l|}{ Unincorporated: } \\
\hline Forest industry & W & W & 0 & 0 & W & 34.3 \\
\hline Farm & 3,900 & 100 & 7,900 & 39 & 11,800 & 68.1 \\
\hline Misc. individual & 0 & 0 & 10,900 & 55 & 10,900 & 84.6 \\
\hline Real estate & 0 & 0 & 1,200 & 6 & 1,200 & 94.6 \\
\hline Other & W & W & 0 & 0 & W & 83.2 \\
\hline Total noncorporate & 3,900 & 100 & 20,000 & 100 & 23,900 & 47.3 \\
\hline Total & 3,900 & 100 & 20,000 & 100 & 23,900 & 47.3 \\
\hline SE & 94.4 & & 56.2 & & 47.3 & \\
\hline \multicolumn{7}{|c|}{ (In thousands of acres) } \\
\hline \multicolumn{7}{|l|}{ Unincorporated: } \\
\hline Forest industry & 5,147 & 80 & 0 & 0 & 5,147 & 22 \\
\hline Farm & 79 & 1 & 79 & 25 & 157 & 94.1 \\
\hline Misc. individual & 0 & 0 & 157 & 50 & 157 & 94.1 \\
\hline Real estate & 0 & 0 & 79 & 25 & 79 & 100 \\
\hline Other & 1,217 & 19 & 0 & 0 & 1,217 & 79.2 \\
\hline Total noncorporate & 6,443 & 100 & 314 & 100 & 6,757 & 0.1 \\
\hline Total & 6,443 & 100 & 314 & 100 & 6,757 & 0.1 \\
\hline SE & 3.8 & & 78.2 & & 0.1 & \\
\hline
\end{tabular}

W- Fewer than 50 owners or less than 0.5 percent 


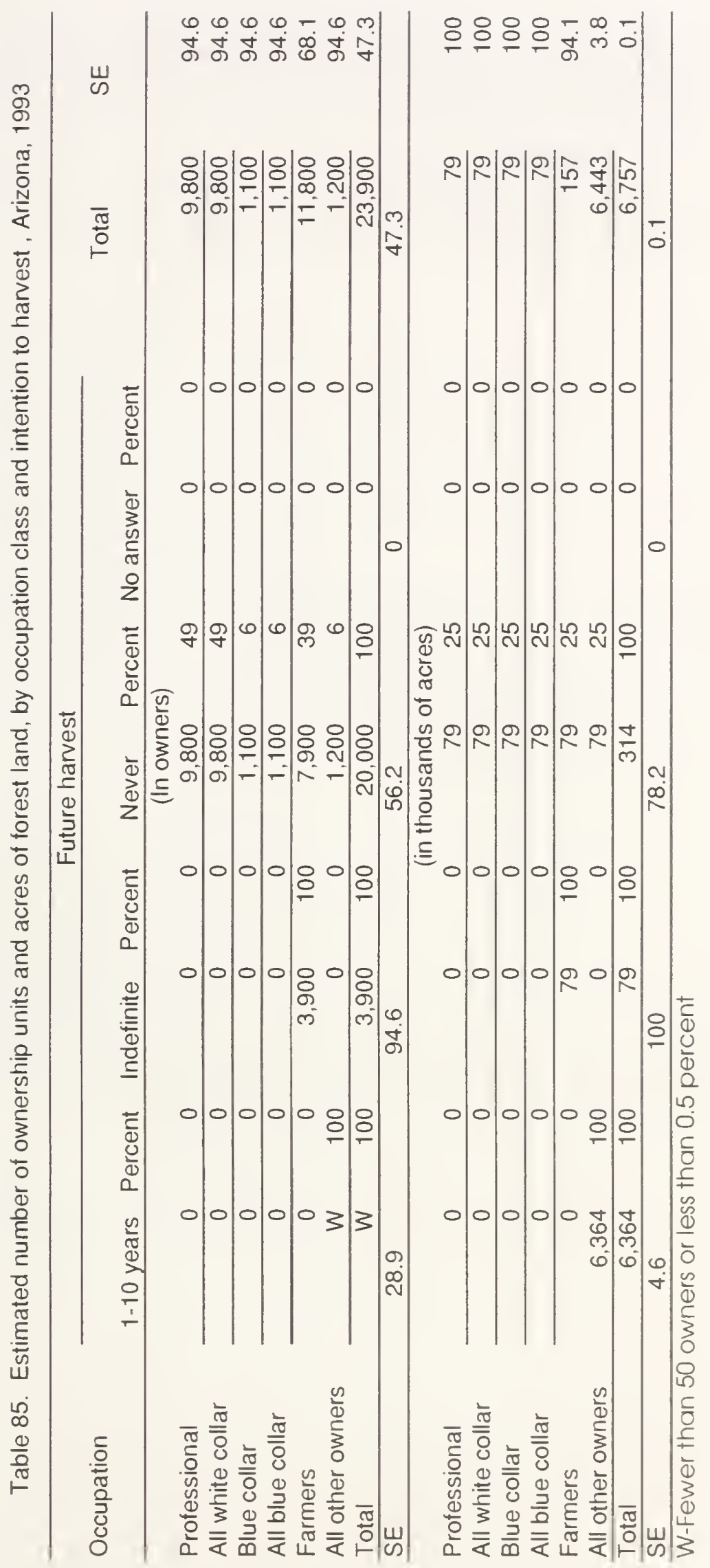


Table 86. Estimated number of ownership units and acres of forest land, by age class and past harvest experience, Arizona, 1993

\begin{tabular}{|c|c|c|c|c|c|c|}
\hline \multirow[t]{2}{*}{ Age } & \multicolumn{4}{|c|}{ Harvest experience } & \multirow{2}{*}{ Total } & \multirow{2}{*}{ SE } \\
\hline & Harvested & Percent & Did not harvest & Percent & & \\
\hline \multicolumn{7}{|c|}{ (In owners) } \\
\hline Under 25 & 0 & 0 & 0 & 0 & 0 & 0 \\
\hline $25-34$ & 0 & 0 & 0 & 0 & 0 & 0 \\
\hline $35-44$ & 0 & 0 & 1,100 & 6 & 1,100 & 94.6 \\
\hline $45-54$ & 0 & 0 & 9,800 & 49 & 9,800 & 94.6 \\
\hline $55-64$ & 3,900 & 100 & 7,900 & 39 & 11,800 & 68.1 \\
\hline 65 or over & 0 & 0 & 0 & 0 & 0 & 0 \\
\hline All other owners & W & W & 1,200 & 6 & 1,200 & 94.6 \\
\hline Total & 3,900 & 100 & 20,000 & 100 & 23,900 & 47.3 \\
\hline SE & 94.4 & & 56.2 & & 47.3 & \\
\hline \multicolumn{7}{|c|}{ (In thousands of acres) } \\
\hline Under 25 & 0 & 0 & 0 & 0 & 0 & 0 \\
\hline $25-34$ & 0 & 0 & 0 & 0 & 0 & 0 \\
\hline $35-44$ & 0 & 0 & 79 & 25 & 79 & 100 \\
\hline $45-54$ & 0 & 0 & 79 & 25 & 79 & 100 \\
\hline $55-64$ & 79 & 1 & 79 & 25 & 157 & 94.1 \\
\hline 65 or over & 0 & 0 & 0 & 0 & 0 & 0 \\
\hline All other owners & 6,364 & 99 & 79 & 25 & 6,443 & 3.8 \\
\hline Total & 6,443 & 100 & 314 & 100 & 6,757 & 0.1 \\
\hline SE & 3.8 & & 78.9 & & 0.1 & \\
\hline
\end{tabular}

W-Fewer than 50 owners of less than 0.5 percent 
Table 87. Estimated number of ownership units and acres of forest land, by date of aquisition and form of ownership, Arizona, 1993

\begin{tabular}{|c|c|c|c|c|c|c|c|}
\hline \multirow[b]{2}{*}{$\begin{array}{c}\text { Date of } \\
\text { acquisition }\end{array}$} & \multicolumn{5}{|c|}{ Ownership class } & \multirow[b]{2}{*}{ Total } & \multirow[b]{2}{*}{ SE } \\
\hline & $\begin{array}{c}\text { Forest } \\
\text { industry }\end{array}$ & Farmer & $\begin{array}{l}\text { Miscellaneous: } \\
\text { Individual }\end{array}$ & Corporation & Other & & \\
\hline \multicolumn{8}{|c|}{ (In owners) } \\
\hline $1990-1994$ & 0 & 0 & 0 & 0 & 0 & 0 & 0 \\
\hline $1980-1989$ & 0 & 3,900 & 0 & 0 & 1,200 & 5,100 & 73.9 \\
\hline $1970-1979$ & 0 & 7,900 & 1,100 & 0 & 0 & 9,000 & 82.6 \\
\hline 1960-1969 & 0 & 0 & 0 & 0 & 0 & 0 & 0 \\
\hline $1950-1959$ & 0 & 0 & 0 & 0 & 0 & 0 & 0 \\
\hline $1940-1949$ & 0 & 0 & 0 & 0 & 0 & 0 & 0 \\
\hline $1901-1939$ & 0 & 0 & 9,800 & 0 & 0 & 9,800 & 94.6 \\
\hline Prior to 1900 & $W$ & 0 & 0 & 0 & W & W & 28.9 \\
\hline No answer & 0 & 0 & 0 & 0 & 0 & 0 & 0 \\
\hline Total & $W$ & 11,800 & 10,900 & 0 & 1,200 & 23,900 & 47.3 \\
\hline SE & 34.3 & 68.1 & 84.6 & 0 & 94.5 & 47.3 & \\
\hline \multicolumn{8}{|c|}{ (In thousands of acres) } \\
\hline 1990-1994 & 0 & 0 & 0 & 0 & 0 & 0 & 0 \\
\hline 1980-1989 & 0 & 79 & 0 & 0 & 79 & 157 & 94.1 \\
\hline $1970-1979$ & 0 & 79 & 79 & 0 & 0 & 157 & 94.1 \\
\hline $1960-1969$ & 0 & 0 & 0 & 0 & 0 & 0 & 0 \\
\hline 1950-1959 & 0 & 0 & 0 & 0 & 0 & 0 & 0 \\
\hline $1940-1949$ & 0 & 0 & 0 & 0 & 0 & 0 & 0 \\
\hline $1901-1939$ & 0 & 0 & 79 & 0 & 0 & 79 & 100 \\
\hline Prior to 1900 & 5,147 & 0 & 0 & 0 & 1,217 & 6,364 & 4.6 \\
\hline No answer & 0 & 0 & 0 & 0 & 0 & 0 & 0 \\
\hline Total & 5,147 & 157 & 157 & 0 & 1,296 & 6.757 & 0.1 \\
\hline SE & 22 & 94.1 & 94.1 & 0 & 76.8 & 0.1 & \\
\hline
\end{tabular}

W-fewer than 50 owners or less than 0.5 percent 
Table 88. Estimated number of ownership units and acres of forest land, by distance from tracts, Arizona, 1993

\begin{tabular}{|c|c|c|c|c|}
\hline \multirow[t]{3}{*}{ Distance } & \multicolumn{3}{|c|}{ Tracts } & \multirow{3}{*}{ Total } \\
\hline & \multirow[b]{2}{*}{1 tract } & \multicolumn{2}{|c|}{ More than one tract } & \\
\hline & & Nearest tract & Farthest tract & \\
\hline \multicolumn{5}{|c|}{ (In owners) } \\
\hline Less than 1 mile & 0 & W & 0 & \\
\hline 2-5 miles & 0 & 0 & 0 & \\
\hline 6-15 miles & 0 & W & 0 & \\
\hline $16-25$ miles & 0 & 0 & 0 & \\
\hline 26-50 miles & 0 & 0 & 0 & \\
\hline $51-100$ miles & 0 & 0 & W & \\
\hline More than 100 miles & 15,000 & 9,000 & 9,000 & \\
\hline No answer & 0 & W & W & \\
\hline Total & 15,000 & 9,000 & 9,000 & 23,900 \\
\hline \multicolumn{5}{|c|}{ (In thousands of acres) } \\
\hline Less than 1 mile & 0 & 520 & 0 & \\
\hline $2-5$ miles & 0 & 0 & 0 & \\
\hline $6-15$ miles & 0 & 197 & 0 & \\
\hline $16-25$ miles & 0 & 0 & 0 & \\
\hline 26-50 miles & 0 & 0 & 0 & \\
\hline $51-100$ miles & 0 & 0 & 717 & \\
\hline More than 100 miles & 236 & 157 & 157 & \\
\hline No answer & 0 & 5,647 & 5,647 & \\
\hline Total & 236 & 6,522 & 6,522 & 6,757 \\
\hline
\end{tabular}

W-Fewer than 50 owners or less than 0.5 percent 
Table 89. Estimated number of ownership units and acres of forest land, by primary and secondary reason for owning forest !and, Arizona, 1993

\begin{tabular}{|c|c|c|c|c|}
\hline \multirow[t]{2}{*}{ Reason } & \multicolumn{2}{|c|}{ Primary reason } & \multicolumn{2}{|c|}{ Secondary reason } \\
\hline & Number & Percent & Number & Percent \\
\hline & \multicolumn{4}{|c|}{ (In owners) } \\
\hline Land investment & 1,200 & 5 & 1,100 & 5 \\
\hline Recreation & 0 & 0 & 7,900 & 33 \\
\hline Timber production & W & W & W & W \\
\hline Farm and domestic use & 3,900 & 16 & 0 & 0 \\
\hline Esthetic enjoyment & 9,000 & 38 & 3,900 & 16 \\
\hline Part of farm & 0 & 0 & 0 & 0 \\
\hline Part of residence & 9,800 & 41 & 0 & 0 \\
\hline Estate & 0 & 0 & 0 & 0 \\
\hline Other & W & W & W & W \\
\hline No secondary reason given & - & - & 11,000 & 46 \\
\hline No answer & 0 & 0 & 0 & 0 \\
\hline \multirow[t]{2}{*}{ Total } & 23,900 & 100 & 23,900 & 100 \\
\hline & \multicolumn{4}{|c|}{ (In thousands of acres) } \\
\hline Land investment & 79 & 1 & 79 & 1 \\
\hline Recreation & 0 & 0 & 1,076 & 16 \\
\hline Timber production & 1,300 & 19 & 700 & 10 \\
\hline Farm and domestic use & 3,923 & 58 & 0 & 0 \\
\hline Esthetic enjoyment & 157 & 2 & 79 & 1 \\
\hline Part of farm & 0 & 0 & 0 & 0 \\
\hline Part of residence & 79 & 1 & 0 & 0 \\
\hline Estate & 0 & 0 & 0 & 0 \\
\hline Other & 1,220 & 18 & 4,147 & 61 \\
\hline No secondary reason given & - & - & 677 & 10 \\
\hline No answer & 0 & 0 & 0 & 0 \\
\hline Total & 6.757 & 100 & 6.757 & 100 \\
\hline
\end{tabular}

W-Fewer than 50 owners or less than 0.5 percent 
Table 90. Estimated number of ownership units and acres of forest land, by primary benefit expected in the next 10 years and past harvest experience, Arizona, 1993

\begin{tabular}{|c|c|c|c|c|c|c|}
\hline \multirow[t]{2}{*}{ Benefits expected } & \multicolumn{4}{|c|}{ Harvest Experience } & \multirow{2}{*}{ Total } & \multirow{2}{*}{ SE } \\
\hline & Harvested & Percent & Did not harvest & Percent & & \\
\hline \multicolumn{7}{|c|}{ (In owners) } \\
\hline Land value increase & 0 & 0 & 1,200 & 6 & 1,200 & 94.6 \\
\hline Recreation & W & W & 0 & 0 & W & 96.2 \\
\hline Income from timber & W & w & 0 & 0 & W & 100 \\
\hline Farm and domestic use & W & W & 0 & 0 & w & 55.6 \\
\hline Esthetic enjoyment & 3,900 & 100 & 18,800 & 94 & 22,700 & 50.4 \\
\hline Firewood & 0 & 0 & 0 & 0 & 0 & 0 \\
\hline Other & W & w & 0 & 0 & w & 88 \\
\hline No answer & 0 & 0 & 0 & 0 & 0 & 0 \\
\hline Total & 3,900 & 100 & 20,000 & 100 & 23,900 & 47.3 \\
\hline SE & 94.4 & & 56.2 & & 47.3 & \\
\hline \multicolumn{7}{|c|}{ (In thousands of acres) } \\
\hline Land value increase & 0 & 0 & 79 & 25 & 79 & 100 \\
\hline Recreation & 697 & 11 & 0 & 0 & 697 & 93.9 \\
\hline Income from timber & 800 & 12 & 0 & 0 & 800 & 100 \\
\hline Farm and domestic us $\epsilon$ & 3,647 & 57 & 0 & 0 & 3,647 & 52.4 \\
\hline Esthetic enjoyment & 79 & 1 & 236 & 75 & 314 & 78.2 \\
\hline Firewood & 0 & 0 & 0 & 0 & 0 & 0 \\
\hline Other & 1,220 & 19 & 0 & 0 & 1,220 & 84.9 \\
\hline No answer & 0 & 0 & 0 & 0 & 0 & 0 \\
\hline Total & 6,443 & 100 & 314 & 100 & 6,757 & 0.1 \\
\hline SE & 3.8 & & 78.2 & & 0.1 & \\
\hline
\end{tabular}

W-fewer than 50 owners or less than 0.5 percent 


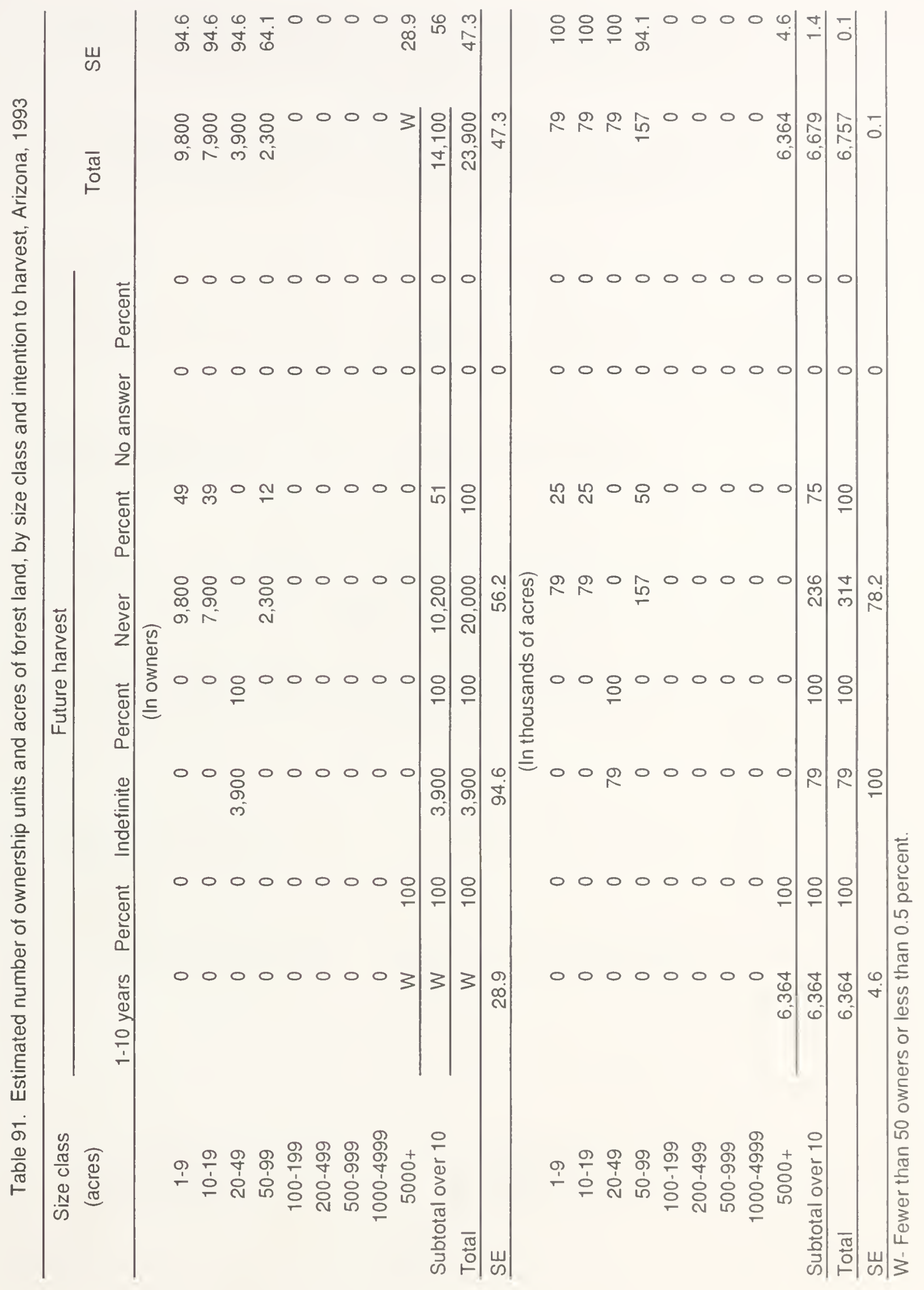




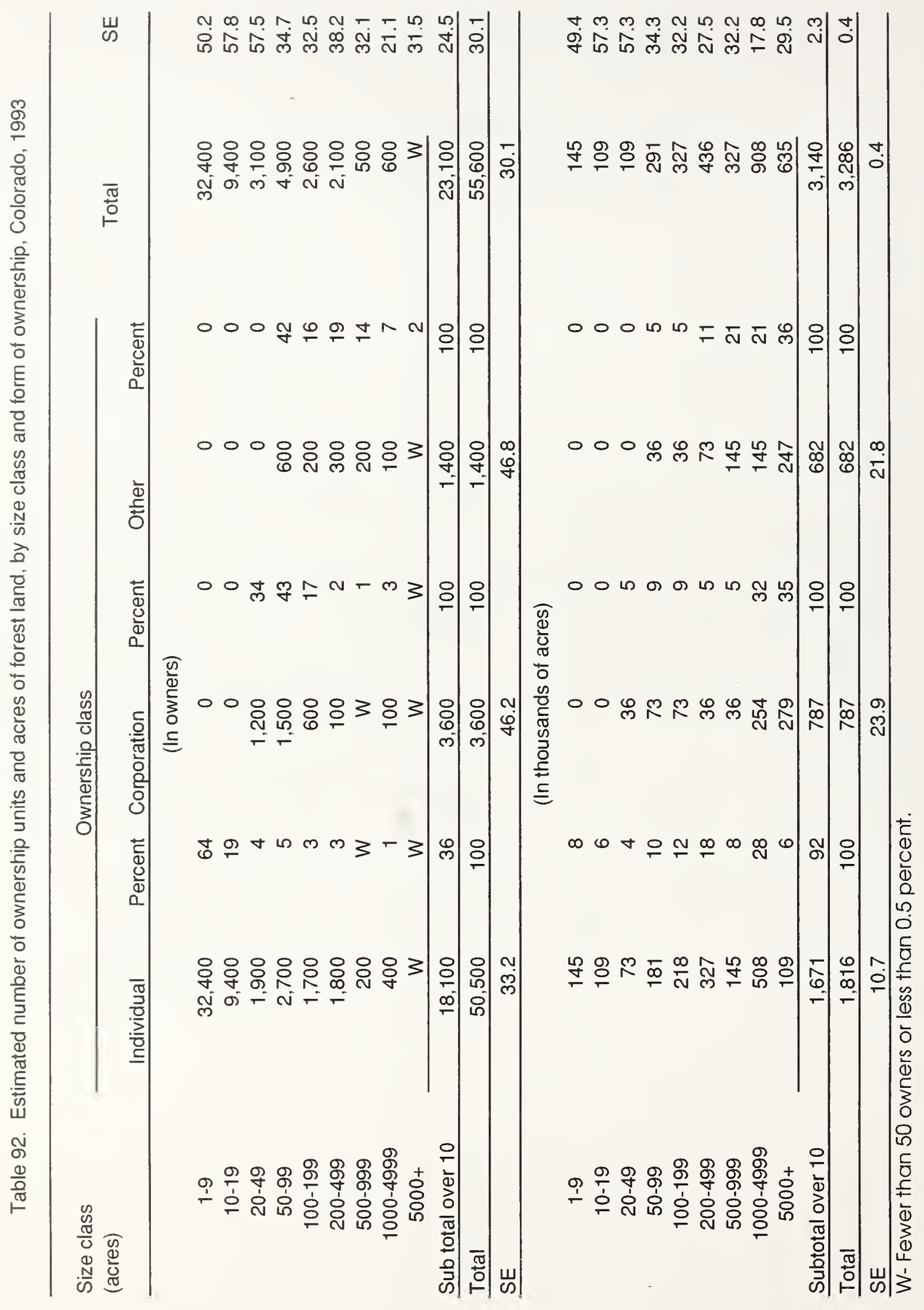


Table 93. Estimated number of ownership units and acres of forest land, by form of ownership and past harvest experience, Colorado, 1993

\begin{tabular}{|c|c|c|c|c|c|c|}
\hline \multirow[t]{2}{*}{ Form of ownership } & \multicolumn{4}{|c|}{ Harvest experience } & \multirow{2}{*}{ Total } & \multirow{2}{*}{ SE } \\
\hline & Harvested & Percent & Did not harvest & Percent & & \\
\hline \multicolumn{7}{|c|}{ (In owners) } \\
\hline Individual + joint & 17,000 & 90 & 33,500 & 91 & 50,500 & 33.2 \\
\hline Partnership & 200 & 1 & 800 & 2 & 1,100 & 58.6 \\
\hline Corporation & 1,600 & 9 & 1,900 & 5 & 3,600 & 46.2 \\
\hline Other & W & W & 400 & 1 & 400 & 71.3 \\
\hline Total & 18,900 & 100 & 36,700 & 100 & 55,600 & 30.1 \\
\hline SE & 51.5 & & 38.7 & & 30.1 & \\
\hline \multicolumn{7}{|c|}{ (In thousands of acres) } \\
\hline Individual + joint & 1,017 & 54 & 799 & 56 & 1.816 & 10.7 \\
\hline Partnership & 327 & 17 & 181 & 13 & 508 & 25.2 \\
\hline Corporation & 461 & 25 & 327 & 23 & 787 & 23.9 \\
\hline Other & 65 & 3 & 109 & 8 & 174 & 50.8 \\
\hline Total & 1,869 & 100 & 1,416 & 100 & 3.286 & 0.4 \\
\hline SE & 9.9 & & 13.1 & & 0.4 & \\
\hline
\end{tabular}

W-Fewer than 50 owners or less than 0.5 percent 
Table 94. Estimated number of ownership units and acres of forest land, by incorporated and unincorporated businesses and past harvest experience, Colorado, 1993

\begin{tabular}{|c|c|c|c|c|c|c|}
\hline \multirow[t]{2}{*}{ Nature of business } & \multicolumn{4}{|c|}{ Harvest } & \multirow{2}{*}{ Total } & \multirow{2}{*}{ SE } \\
\hline & Harvested & Percent & Did not harvest & Percent & & \\
\hline \multicolumn{7}{|c|}{ (In owners) } \\
\hline \multicolumn{7}{|l|}{ Incorporated: } \\
\hline Farm & 100 & W & W & W & 100 & 72.6 \\
\hline Industrial business & 100 & W & 1,000 & 3 & 1,000 & 69 \\
\hline Real estate & W & W & 900 & 3 & 900 & 96.5 \\
\hline Sport/ recreation club & 1,500 & 8 & 0 & 0 & 1,500 & 84.3 \\
\hline Other & W & W & 0 & 0 & W & 100 \\
\hline Total corporate & 1,600 & 9 & 1,900 & 5 & 3,600 & 46.2 \\
\hline \multicolumn{7}{|l|}{ Unincorporated: } \\
\hline Farm & 900 & 5 & 4,400 & 12 & 5,200 & 49.3 \\
\hline Misc. individual & 16,300 & 86 & 29,400 & 80 & 45,700 & 36.7 \\
\hline Real estate & W & W & 600 & 2 & 600 & 94.1 \\
\hline Other & 100 & W & 400 & 1 & 400 & 64.5 \\
\hline Total noncorporate & 17,200 & 91 & 34,700 & 95 & 52,000 & 32.3 \\
\hline Total & 18,900 & 100 & 36,700 & 100 & 55,600 & 30.1 \\
\hline $\mathrm{SE}$ & 51.5 & & 38.7 & & 30.1 & \\
\hline \multicolumn{7}{|c|}{ (In thousands of acres) } \\
\hline Incorporated: & & & & & & \\
\hline Farm & 36 & 2 & 109 & 8 & 145 & 49.4 \\
\hline Industrial business & 73 & 4 & 109 & 8 & 181 & 44 \\
\hline Real estate & 36 & 2 & 109 & 8 & 145 & 49.4 \\
\hline Sport/ recreation club & 279 & 15 & 0 & 0 & 279 & 60.7 \\
\hline Other & 36 & 2 & 0 & 0 & 36 & 100 \\
\hline Total corporate & 461 & 25 & 327 & 23 & 787 & 23.9 \\
\hline \multicolumn{7}{|l|}{ Unincorporated: } \\
\hline Farm & 937 & 50 & 545 & 38 & 1,481 & 12.7 \\
\hline Misc. individual & 399 & 21 & 399 & 28 & 799 & 19.3 \\
\hline Real estate & 36 & 2 & 73 & 5 & 109 & 57.3 \\
\hline Other & 36 & 2 & 73 & 5 & 109 & 57.3 \\
\hline Total noncorporate & 1,409 & 75 & 1,089 & 77 & 2,498 & 7.5 \\
\hline Total & 1,869 & 100 & 1,416 & 100 & 3,286 & 0.4 \\
\hline SE & 9.9 & & 13.1 & & 0.4 & \\
\hline
\end{tabular}

W- Fewer than 50 owners or less than 0.5 percent 


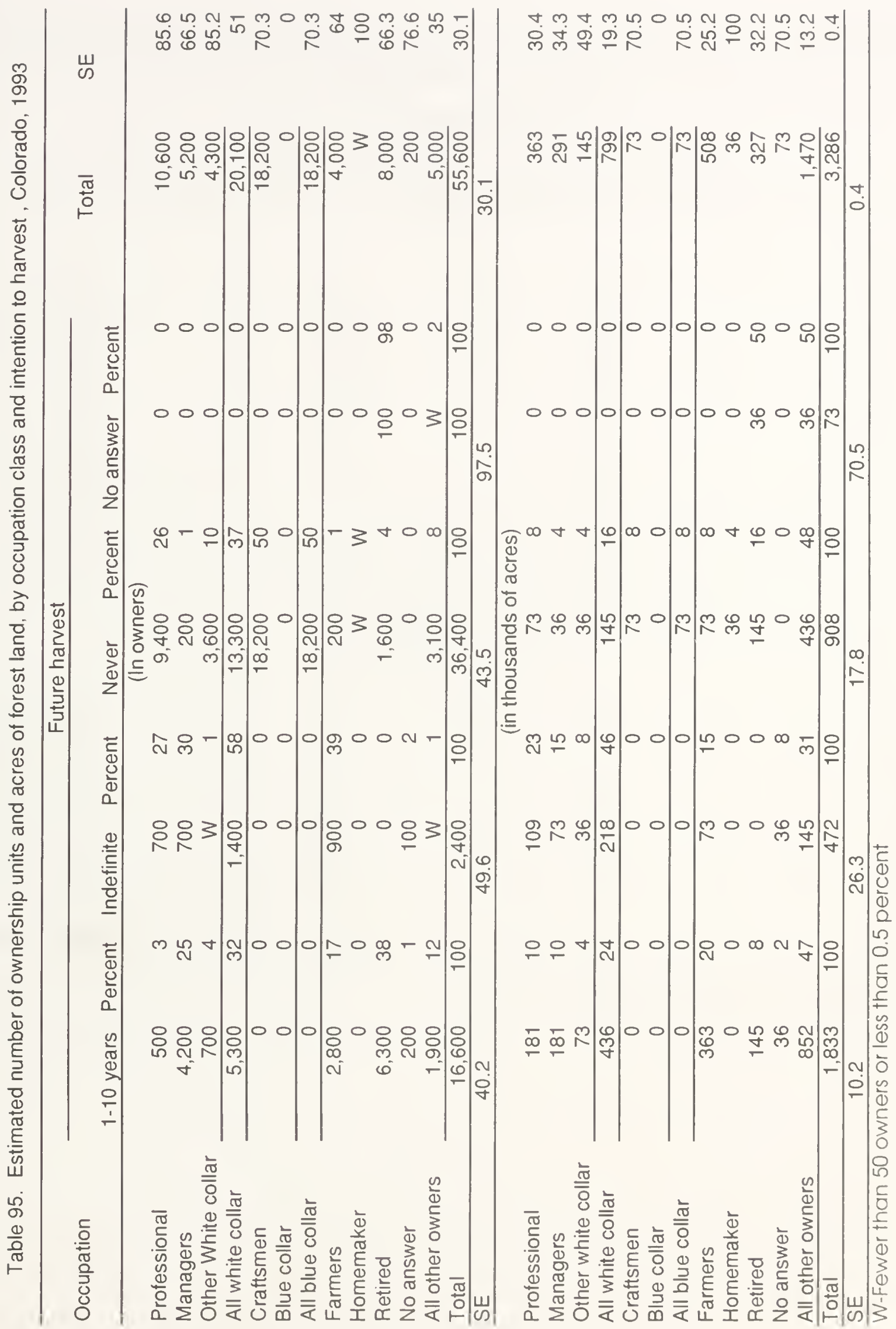


Table 96. Estimated number of ownership units and acres of forest land, by age class and past harvest experience, Colorado, 1993

\begin{tabular}{|c|c|c|c|c|c|c|}
\hline \multirow[t]{2}{*}{ Age } & \multicolumn{4}{|c|}{ Harvest experience } & \multirow{2}{*}{ Total } & \multirow{2}{*}{ SE } \\
\hline & Harvested & Percent & Did not harvest & Percent & & \\
\hline \multicolumn{7}{|c|}{ (In owners) } \\
\hline Under 25 & 0 & 0 & 0 & 0 & 0 & 0 \\
\hline $25-34$ & 0 & 0 & 0 & 0 & 0 & 0 \\
\hline $35-44$ & 13,900 & 74 & 9,100 & 25 & 23,000 & 57.2 \\
\hline $45-54$ & 400 & 2 & 4,600 & 13 & 5,000 & 73.5 \\
\hline $55-64$ & 1,200 & 7 & 3,400 & 9 & 4,600 & 57.8 \\
\hline 65 or over & 1,300 & 7 & 16,400 & 45 & 17,800 & 58.7 \\
\hline No answer & 200 & 1 & 100 & W & 200 & 76.6 \\
\hline All other owners & 1,900 & 10 & 3,200 & 9 & 5,000 & 35 \\
\hline Total & 18,900 & 100 & 36,700 & 100 & 55,600 & 30.1 \\
\hline SE & 51.5 & & 38.7 & & 30.1 & \\
\hline \multicolumn{7}{|c|}{ (In thousands of acres) } \\
\hline Under 25 & 0 & 0 & 0 & 0 & 0 & 0 \\
\hline $25-34$ & 0 & 0 & 0 & 0 & 0 & 0 \\
\hline $35-44$ & 218 & 12 & 36 & 3 & 254 & 36.8 \\
\hline $45-54$ & 73 & 4 & 254 & 18 & 327 & 32.2 \\
\hline $55-64$ & 363 & 19 & 109 & 8 & 472 & 26.3 \\
\hline 65 or over & 327 & 17 & 363 & 26 & 690 & 21.1 \\
\hline No answer & 36 & 2 & 36 & 3 & 73 & 70.5 \\
\hline All other owners & 852 & 46 & 617 & 43 & 1,470 & 13.2 \\
\hline Total & 1,869 & 100 & 1,416 & 100 & 3,286 & 0.4 \\
\hline SE & 9.9 & & 13.1 & & 0.4 & \\
\hline
\end{tabular}

W-Fewer than 50 owners of less than 0.5 percent 
Table 97. Estimated number of ownership units and acres of forest land, by date of aquisition and form of ownership, Colorado, 1993

\begin{tabular}{|c|c|c|c|c|c|c|c|}
\hline \multirow[b]{2}{*}{$\begin{array}{c}\text { Date of } \\
\text { acquisition }\end{array}$} & \multicolumn{5}{|c|}{ Ownership class } & \multirow[b]{2}{*}{ Total } & \multirow[b]{2}{*}{ SE } \\
\hline & $\begin{array}{l}\text { Forest } \\
\text { industry }\end{array}$ & Farmer & $\begin{array}{c}\text { Miscellaneous: } \\
\text { Individual }\end{array}$ & Corporation & Other & & \\
\hline \multicolumn{8}{|c|}{ (In owners) } \\
\hline $1990-1994$ & 0 & 900 & 19,700 & W & 0 & 20,700 & 61.9 \\
\hline $1980-1989$ & 0 & 400 & 9,400 & 900 & 100 & 10,700 & 57.7 \\
\hline $1970-1979$ & 0 & 2,700 & 14,000 & 1,000 & 0 & 17,700 & 56.5 \\
\hline $1960-1969$ & 0 & 600 & 1,700 & 1,500 & 600 & 4,400 & 39.6 \\
\hline $1950-1959$ & 0 & 200 & 0 & W & 0 & 200 & 61.3 \\
\hline $1940-1949$ & 0 & 300 & 100 & W & 400 & 900 & 40 \\
\hline $1901-1939$ & 0 & 200 & 0 & W & 0 & 100 & 41.7 \\
\hline Prior to 1900 & 0 & W & 0 & 0 & 0 & W & 94.3 \\
\hline No answer & 0 & $W$ & 800 & 0 & 0 & 800 & 81.4 \\
\hline Total & 0 & 5,400 & 45,700 & 3,500 & 1,100 & 55,600 & 30.1 \\
\hline SE & 0 & 48.2 & 36.7 & 47.8 & 62.4 & 30.1 & \\
\hline \multicolumn{8}{|c|}{ (In thousands of acres) } \\
\hline $1990-1994$ & 0 & 73 & 181 & 36 & 0 & 291 & 34.3 \\
\hline 1980-1989 & 0 & 327 & 218 & 109 & 36 & 690 & 21.1 \\
\hline $1970-1979$ & 0 & 291 & 181 & 73 & 0 & 545 & 24.2 \\
\hline $1960-1969$ & 0 & 254 & 145 & 279 & 73 & 751 & 24.9 \\
\hline $1950-1959$ & 0 & 181 & 0 & 36 & 0 & 218 & 40 \\
\hline $1940-1949$ & 0 & 145 & 36 & 73 & 73 & 327 & 32.2 \\
\hline $1901-1939$ & 0 & 218 & 0 & 36 & 0 & 254 & 36.8 \\
\hline Prior to 1900 & 0 & 101 & 0 & 0 & 0 & 101 & 72.6 \\
\hline No answer & 0 & 36 & 73 & 0 & 0 & 109 & 57.3 \\
\hline Total & 0 & 1,627 & 835 & 642 & 181 & 3,286 & 0.4 \\
\hline SE & 0 & 11.7 & 18.7 & 28.7 & 44 & 0.4 & \\
\hline
\end{tabular}

W-fewer than 50 owners or less than 0.5 percent 
Table 98. Estimated number of ownership units and acres of forest land, by distance from tracts, Colorado, 1993

\begin{tabular}{|c|c|c|c|c|}
\hline \multirow[t]{3}{*}{ Distance } & \multicolumn{3}{|c|}{ Tracts } & \multirow{3}{*}{ Total } \\
\hline & \multirow[b]{2}{*}{1 tract } & \multicolumn{2}{|c|}{ More than one tract } & \\
\hline & & Nearest tract & Farthest tract & \\
\hline \multicolumn{5}{|c|}{ (In owners) } \\
\hline Less than 1 mile & 5,900 & 6,300 & 3,700 & \\
\hline 2-5 miles & 9,100 & 100 & 1,100 & \\
\hline 6-15 miles & 100 & 200 & 200 & \\
\hline $16-25$ miles & 1,200 & W & W & \\
\hline $26-50$ miles & 9,500 & 300 & 100 & \\
\hline $51-100$ miles & 1,200 & 700 & 700 & \\
\hline More than 100 miles & 18,100 & 2,100 & 4,000 & \\
\hline No answer & 800 & W & W & \\
\hline Total & 45,800 & 9,800 & 9,800 & 55,600 \\
\hline \multicolumn{5}{|c|}{ (In thousands of acres) } \\
\hline Less than 1 mile & 363 & 787 & 109 & \\
\hline 2-5 miles & 36 & 210 & 218 & \\
\hline 6-15 miles & 36 & 291 & 327 & \\
\hline $16-25$ miles & 73 & 36 & 36 & \\
\hline 26-50 miles & 145 & 181 & 388 & \\
\hline $51-100$ miles & 73 & 109 & 138 & \\
\hline More than 100 miles & 399 & 436 & 835 & \\
\hline No answer & 73 & 36 & 36 & \\
\hline Total & 1,198 & 2,087 & 2,087 & 3,286 \\
\hline
\end{tabular}

W-Fewer than 50 owners or less than 0.5 percent 
Table 99. Estimated number of ownership units and acres of forest land, by primary and secondary reason for owning forest land, Colorado, 1993

\begin{tabular}{|c|c|c|c|c|}
\hline \multirow[t]{2}{*}{ Reason } & \multicolumn{2}{|c|}{ Primary reason } & \multicolumn{2}{|c|}{ Secondary reason } \\
\hline & Number & Percent & Number & Percent \\
\hline & \multicolumn{4}{|c|}{ (In owners) } \\
\hline Land investment & 2,600 & 5 & 1,800 & 3 \\
\hline Recreation & 7,500 & 13 & 1,100 & 2 \\
\hline Timber production & 100 & W & W & W \\
\hline Farm and domestic use & 300 & 1 & 1,700 & 3 \\
\hline Esthetic enjoyment & 26,100 & 47 & 1,000 & 2 \\
\hline Part of farm & 1,500 & 3 & 200 & W \\
\hline Part of residence & 1,400 & 3 & 20,800 & 37 \\
\hline Estate & 3,700 & 7 & 700 & 1 \\
\hline Other & 12,300 & 22 & 3,300 & 6 \\
\hline No secondary reason given & - & - & 24,800 & 45 \\
\hline No answer & 200 & $W$ & 200 & W \\
\hline \multirow[t]{2}{*}{ Total } & 55,600 & 100 & 55,600 & 100 \\
\hline & \multicolumn{4}{|c|}{ (In thousands of acres) } \\
\hline Land investment & 399 & 12 & 351 & 12 \\
\hline Recreation & 569 & 18 & 181 & 6 \\
\hline Timber production & 36 & 1 & 174 & 6 \\
\hline Farm and domestic use & 109 & 3 & 436 & 12 \\
\hline Esthetic enjoyment & 363 & 12 & 254 & 9 \\
\hline Part of farm & 726 & 21 & 291 & 9 \\
\hline Part of residence & 247 & 7 & 218 & 6 \\
\hline Estate & 218 & 6 & 291 & 9 \\
\hline Other & 545 & 15 & 36 & 1 \\
\hline No secondary reason given & - & - & 981 & 30 \\
\hline No answer & 73 & 3 & 73 & 3 \\
\hline Total & 3,286 & 100 & 3,286 & 100 \\
\hline
\end{tabular}

W-Fewer than 50 owners or less than 0.5 percent 
Table 100. Estimated number of ownership units and acres of forest land, by primary benefit expected in the next 10 years and past harvest experience, Colorado, 1993

\begin{tabular}{|c|c|c|c|c|c|c|}
\hline \multirow[t]{2}{*}{ Benefits expected } & \multicolumn{4}{|c|}{ Harvest Experience } & \multirow{2}{*}{ Total } & \multirow{2}{*}{ SE } \\
\hline & Harvested & Percent & Did not harvest & Percent & & \\
\hline \multicolumn{7}{|c|}{ (In owners) } \\
\hline Land value increase & 1,500 & 8 & 1,400 & 4 & 2,800 & 39.9 \\
\hline Recreation & 1.900 & 10 & 5,400 & 15 & 7,300 & 72.8 \\
\hline Income from timber & 100 & W & W & W & 100 & 63.6 \\
\hline Farm and domestic us $\epsilon$ & 3,900 & 21 & 3,500 & 9 & 726 & 56.2 \\
\hline Esthetic enjoyment & 10,100 & 54 & 15.700 & 43 & 925 & 51.1 \\
\hline Firewood & 0 & 0 & 0 & 0 & 0 & 0 \\
\hline Other & 1,200 & 7 & 10,600 & 29 & 327 & 77.4 \\
\hline No answer & 200 & 1 & 100 & W & 109 & 69.8 \\
\hline Total & 18,900 & 100 & 36,700 & 100 & 3,286 & 30.1 \\
\hline SE & 51.5 & & 38.7 & & 30.1 & \\
\hline \multicolumn{7}{|c|}{ (In thousands of acres) } \\
\hline Land value increase & 363 & 19 & 181 & 13 & 545 & 24.2 \\
\hline Recreation & 291 & 15 & 254 & 18 & 545 & 24.2 \\
\hline Income from timber & 73 & 4 & 36 & 3 & 109 & 57.3 \\
\hline Farm and domestic us $\epsilon$ & 508 & 27 & 218 & 15 & 726 & 20.4 \\
\hline Esthetic enjoyment & 489 & 26 & 436 & 31 & 925 & 20.9 \\
\hline Firewood & 0 & 0 & 0 & 0 & 0 & 0 \\
\hline Other & 109 & 6 & 218 & 15 & 327 & 32.2 \\
\hline No answer & 36 & 2 & 73 & 5 & 109 & 57.3 \\
\hline Total & 1,869 & 100 & 1,416 & 100 & 3,286 & 0.4 \\
\hline SE & 9.9 & & 13.1 & & 0.4 & \\
\hline
\end{tabular}

W-fewer than 50 owners or less than 0.5 percent 


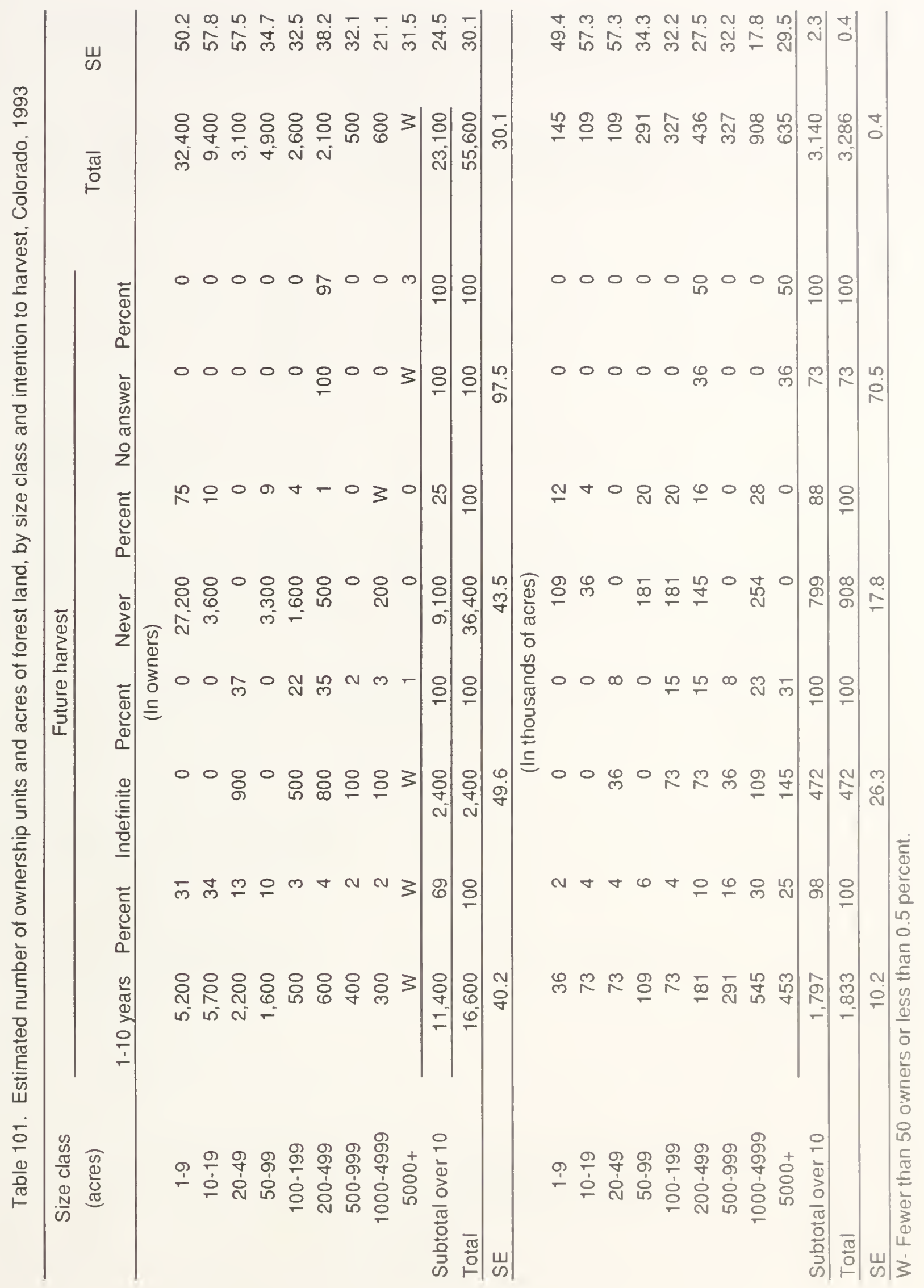




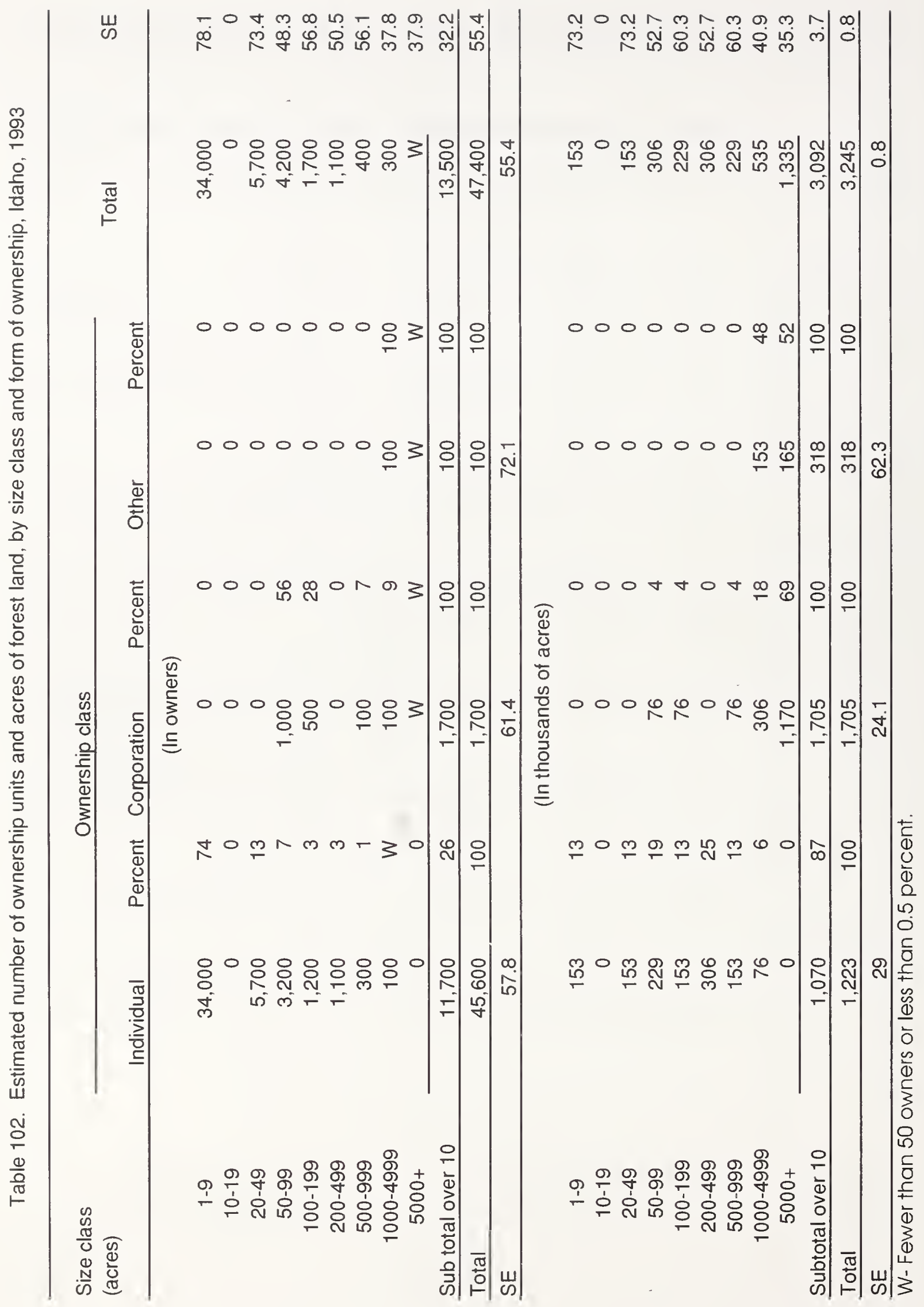


Table 103. Estimated number of ownership units and acres of forest land, by form of ownership and past harvest experience, Idaho, 1993

\begin{tabular}{|c|c|c|c|c|c|c|}
\hline \multirow[t]{2}{*}{ Form of ownership } & \multicolumn{4}{|c|}{ Harvest experience } & \multirow{2}{*}{ Total } & \multirow{2}{*}{ SE } \\
\hline & Harvested & Percent & Did not harvest & Percent & & \\
\hline \multicolumn{7}{|c|}{ (In owners) } \\
\hline Individual + joint & 11,100 & 98 & 34,500 & 96 & 45,600 & 57.8 \\
\hline Partnership & 100 & 1 & 0 & 0 & 100 & 72.1 \\
\hline Corporation & 200 & 1 & 1,600 & 4 & 1,700 & 61.4 \\
\hline Total & 11,300 & 100 & 36,100 & 100 & 47,400 & 55.4 \\
\hline SE & 38.6 & & 73.3 & & 55.4 & \\
\hline \multicolumn{7}{|c|}{ (In thousands of acres) } \\
\hline Individual + joint & 917 & 34 & 306 & 57 & 1,223 & 29 \\
\hline Partnership & 318 & 12 & 0 & 0 & 318 & 62.3 \\
\hline Corporation & 1,475 & 54 & 229 & 43 & 1,705 & 24.1 \\
\hline Total & 2,710 & 100 & 535 & 100 & 3,245 & 0.8 \\
\hline SE & 8.1 & & 40.9 & & 0.8 & \\
\hline
\end{tabular}


Table 104. Estimated number of ownership units and acres of forest land, by incorporated and unincorporated businesses and past harvest experience, Idaho, 1993

\begin{tabular}{|c|c|c|c|c|c|c|}
\hline \multirow[t]{2}{*}{ Nature of business } & \multicolumn{4}{|c|}{ Harvest } & \multirow{2}{*}{ Total } & \multirow{2}{*}{ SE } \\
\hline & Hanvested & Percent & Did not harvest & Percent & & \\
\hline \multicolumn{7}{|c|}{ (In owners) } \\
\hline \multicolumn{7}{|l|}{ Incorporated: } \\
\hline Forest industry & 100 & 1 & 0 & 0 & 100 & 88.7 \\
\hline Farm & 100 & 1 & 100 & W & 200 & 60.8 \\
\hline Sport/ recreation club & 0 & 0 & 1,400 & 4 & 1,400 & 73.4 \\
\hline Other & 0 & 0 & 0 & 0 & 0 & 0 \\
\hline Total corporate & 200 & 2 & 1,600 & 4 & 1,700 & 61.4 \\
\hline \multicolumn{7}{|l|}{ Unincorporated: } \\
\hline Forest industry & W & W & 0 & 0 & W & 100 \\
\hline Farm & 6,400 & 56 & 600 & 2 & 6,900 & 35.4 \\
\hline Misc. individual & 4,800 & 52 & 34,000 & 94 & 38,800 & 68.6 \\
\hline Other & 0 & 0 & 0 & 0 & 0 & 0 \\
\hline Total noncorporate & 11,200 & 99 & 34,500 & 96 & 45,700 & 57.7 \\
\hline Total & 11,300 & 100 & 36,100 & 100 & $\overline{47,400}$ & 55.4 \\
\hline SE & 38.6 & & 73.3 & & 55.4 & \\
\hline \multicolumn{7}{|c|}{ (In thousands of acres) } \\
\hline Incorporated: & & & & & & \\
\hline Forest industry & 1,246 & 46 & 0 & 0 & 1,246 & 38.7 \\
\hline Farm & 229 & 8 & 76 & 14 & 306 & 52.7 \\
\hline Sport/ recreation club & 0 & 0 & 153 & 29 & 153 & 73.2 \\
\hline Other & 0 & 0 & 0 & 1 & 0 & 0 \\
\hline Total corporate & 1,475 & 54 & 229 & 43 & 1,705 & 24.1 \\
\hline \multicolumn{7}{|l|}{ Unincorporated: } \\
\hline Forest industry & 165 & 6 & 0 & 0 & 165 & 99.8 \\
\hline Farm & 917 & 34 & 153 & 29 & 1,070 & 30.6 \\
\hline Misc. individual & 153 & 6 & 153 & 29 & 306 & 52.7 \\
\hline Other & 0 & 9 & 0 & 0 & 0 & 0 \\
\hline Total noncorporate & 1,235 & 46 & 306 & 57 & 1,540 & 26.7 \\
\hline Total & 2,710 & 100 & 535 & 100 & 3,245 & 0.8 \\
\hline SE & 8.1 & & 40.9 & & 0.8 & \\
\hline
\end{tabular}

W- Fewer than 50 owners or less than 0.5 percent 


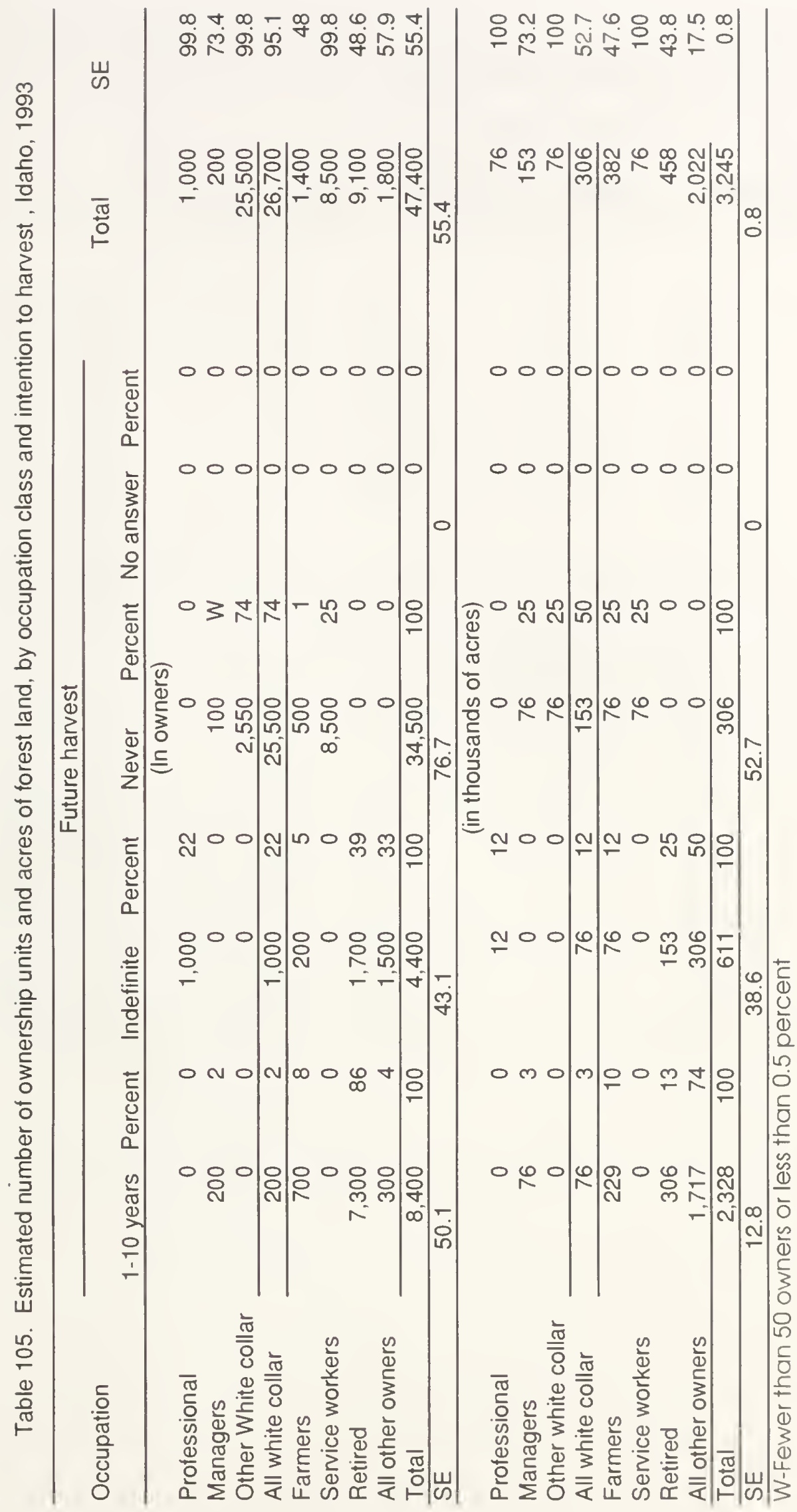


Table 106. Estimated number of ownership units and acres of forest land, by age class and past harvest experience, Idaho, 1993

\begin{tabular}{|c|c|c|c|c|c|c|}
\hline \multirow[t]{2}{*}{ Age } & \multicolumn{4}{|c|}{ Harvest experience } & \multirow{2}{*}{ Total } & \multirow{2}{*}{ SE } \\
\hline & Harvested & Percent & Did not harvest & Percent & & \\
\hline \multicolumn{7}{|c|}{ (In owners) } \\
\hline Under 25 & 0 & 0 & 0 & 0 & 0 & 0 \\
\hline $25-34$ & 200 & 1 & 0 & 0 & 200 & 99.8 \\
\hline $35-44$ & 1,000 & 9 & 8,500 & 23 & 9,500 & 89.6 \\
\hline $45-54$ & 0 & 0 & 500 & 1 & 500 & 99.8 \\
\hline $55-64$ & 200 & 2 & 25,500 & 71 & 25,800 & 98.6 \\
\hline 65 or over & 9,700 & 86 & 0 & 0 & 9,700 & 45.1 \\
\hline All other owners & 300 & 2 & 1,600 & 4 & 1,800 & 57.9 \\
\hline Total & 11,300 & 100 & 36,100 & 100 & 47,400 & 55.4 \\
\hline SE & 38.6 & & 73.3 & & 55.4 & \\
\hline \multicolumn{7}{|c|}{ (In thousands of acres) } \\
\hline Under 25 & 0 & 0 & 0 & 0 & 0 & 0 \\
\hline $25-34$ & 76 & 3 & 0 & 0 & 76 & 100 \\
\hline $35-44$ & 76 & 3 & 76 & 14 & 153 & 73.2 \\
\hline $45-54$ & 0 & 0 & 76 & 14 & 76 & 100 \\
\hline $55-64$ & 76 & 3 & 153 & 29 & 229 & 60.3 \\
\hline 65 or over & 688 & 25 & 9 & 0 & 688 & 36.7 \\
\hline All other owners & 1,793 & 66 & 229 & 42 & 2,022 & 17.5 \\
\hline Total & 2,710 & 100 & 535 & 100 & 3,245 & 0.8 \\
\hline SE & 8.1 & & 40.9 & & 0.8 & \\
\hline
\end{tabular}


Table 107. Estimated number of ownership units and acres of forest land, by date of aquisition and form of ownership, Idaho, 1993

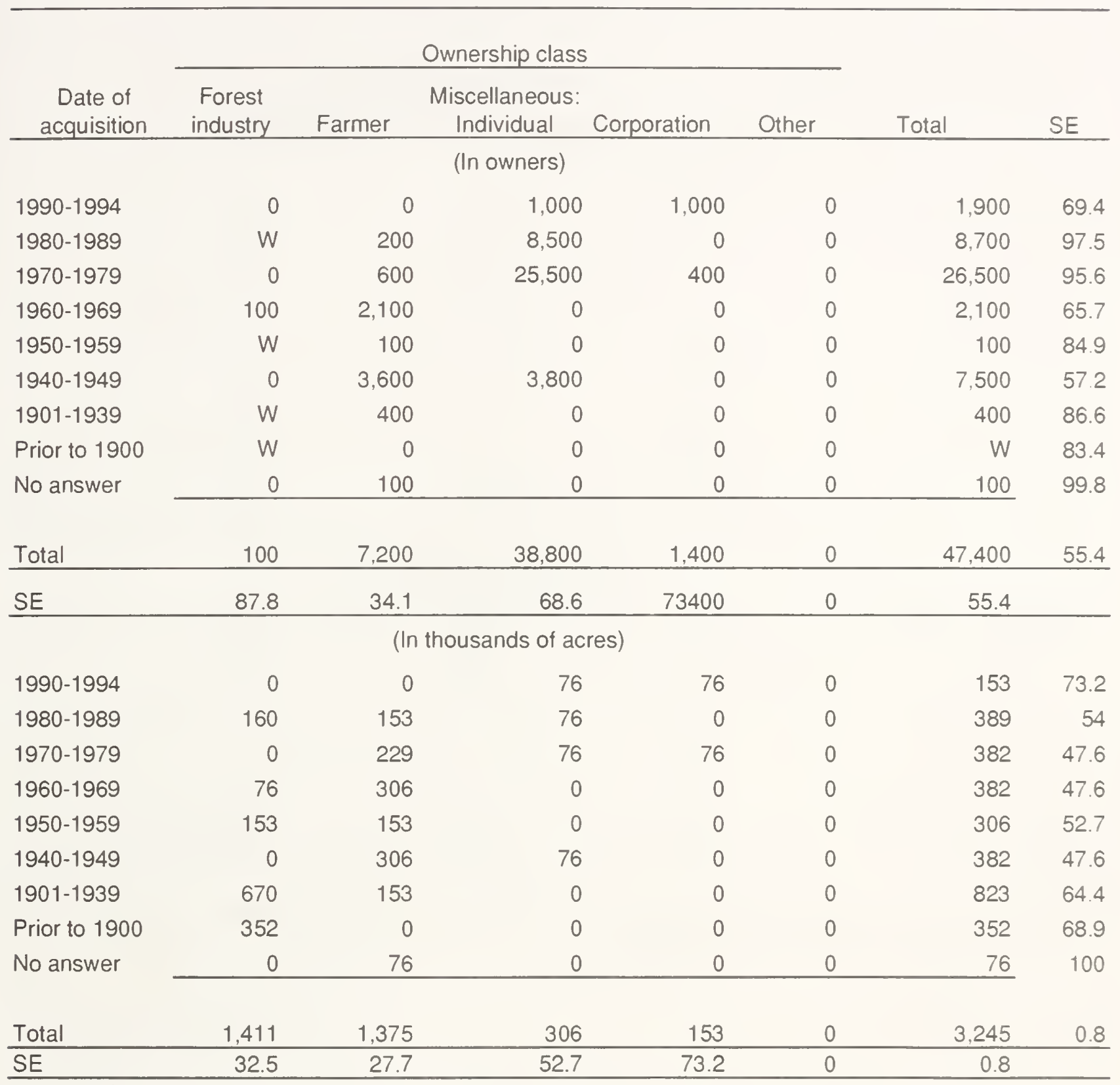

W-fewer than 50 owners or less than 0.5 percent 
Table 108. Estimated number of ownership units and acres of forest land, by distance from tracts, Idaho, 1993

\begin{tabular}{|c|c|c|c|c|}
\hline \multirow[t]{3}{*}{ Distance } & \multicolumn{3}{|c|}{ Tracts } & \multirow{3}{*}{ Total } \\
\hline & \multirow[b]{2}{*}{1 tract } & \multicolumn{2}{|c|}{ More than one tract } & \\
\hline & & Nearest tract & Farthest tract & \\
\hline \multicolumn{5}{|c|}{ (In owners) } \\
\hline Less than 1 mile & 2,400 & 2,500 & 1,700 & \\
\hline $2-5$ miles & 4,700 & 200 & 1,000 & \\
\hline 6-15 miles & 0 & 300 & 100 & \\
\hline $16-25$ miles & 0 & 0 & 0 & \\
\hline 26-50 miles & 3,300 & 0 & 0 & \\
\hline $51-100$ miles & 25,500 & 0 & 100 & \\
\hline More than 100 miles & W & W & 200 & \\
\hline No answer & 8,600 & W & W & \\
\hline Total & 44,400 & 3,000 & 3,000 & 47,400 \\
\hline \multicolumn{5}{|c|}{ (In thousands of acres) } \\
\hline Less than 1 mile & 458 & 569 & 229 & \\
\hline $2-5$ miles & 153 & 318 & 229 & \\
\hline $6-15$ miles & 0 & 229 & 76 & \\
\hline $16-25$ miles & 0 & 0 & 0 & \\
\hline $26-50$ miles & 229 & 0 & 0 & \\
\hline $51-100$ miles & 76 & 0 & 241 & \\
\hline More than 100 miles & 76 & 160 & 500 & \\
\hline No answer & 153 & 823 & 823 & \\
\hline Total & 1,146 & 2,099 & 2,099 & 3,245 \\
\hline
\end{tabular}

W-Fewer than 50 owners or less than 0.5 percent 
Table 109. Estimated number of ownership units and acres of forest land, by primary and secondary reason for owning forest land, Idaho, 1993

\begin{tabular}{|c|c|c|c|c|}
\hline \multirow[t]{2}{*}{ Reason } & \multicolumn{2}{|l|}{ Primary reason } & \multicolumn{2}{|c|}{ Secondary reason } \\
\hline & Number & Percent & Number & Percent \\
\hline & \multicolumn{4}{|c|}{ (In owners) } \\
\hline Land investment & 900 & 2 & 100 & W \\
\hline Recreation & 26,400 & 56 & 9,100 & 19 \\
\hline Timber production & 200 & W & 4,000 & 9 \\
\hline Farm and domestic use & 3,700 & 8 & 100 & W \\
\hline Esthetic enjoyment & 600 & 1 & 2.200 & 5 \\
\hline Part of farm & 1,500 & 3 & 200 & W \\
\hline Part of residence & 1,200 & 3 & 700 & 2 \\
\hline Estate & 0 & 0 & 1,500 & 3 \\
\hline Other & 13,000 & 27 & 1,000 & 2 \\
\hline No secondary reason given & - & - & 28,600 & 60 \\
\hline No answer & 0 & 0 & 0 & 0 \\
\hline \multirow[t]{2}{*}{ Total } & 47,400 & 100 & 47,400 & 100 \\
\hline & \multicolumn{4}{|c|}{ (In thousands of acres) } \\
\hline Land investment & 153 & 5 & 581 & 18 \\
\hline Recreation & 153 & 5 & 229 & 7 \\
\hline Timber production & 1,564 & 48 & 229 & 7 \\
\hline Farm and domestic use & 229 & 7 & 76 & 2 \\
\hline Esthetic enjoyment & 153 & 5 & 229 & 7 \\
\hline Part of farm & 229 & 7 & 76 & 2 \\
\hline Part of residence & 153 & 5 & 76 & 2 \\
\hline Estate & 0 & 0 & 153 & 5 \\
\hline Other & 611 & 19 & 76 & 2 \\
\hline No secondary reason given & - & - & 1.518 & 47 \\
\hline No answer & 0 & 0 & 0 & 0 \\
\hline Total & 3,245 & 100 & 3,245 & 100 \\
\hline
\end{tabular}

W-Fewer than 50 owners or less than 0.5 percent 
Table 110. Estimated number of ownership units and acres of forest land, by primary benefit expected in the next 10 years and past harvest experience, ldaho, 1993

\begin{tabular}{|c|c|c|c|c|c|c|}
\hline \multirow[t]{2}{*}{ Benefits expected } & \multicolumn{4}{|c|}{ Harvest Experience } & \multirow{2}{*}{ Total } & \multirow{2}{*}{ SE } \\
\hline & Harvested & Percent & Did not harvest & Percent & & \\
\hline \multicolumn{7}{|c|}{ (In owners) } \\
\hline Land value increase & 400 & 4 & 0 & 0 & 400 & 64.9 \\
\hline Recreation & 0 & 0 & 26,400 & 73 & 26,400 & 96.1 \\
\hline Income from timber & 800 & 7 & 100 & W & 1.000 & 75.9 \\
\hline Farm and domestic us $€$ & 3,700 & 32 & 0 & 0 & 3,700 & 63.4 \\
\hline Esthetic enjoyment & 1,100 & 10 & 500 & 1 & 1,600 & 68.3 \\
\hline Other & 5,300 & 47 & 9.100 & 25 & 14,400 & 63.5 \\
\hline No answer & 0 & 0 & 0 & 0 & 0 & 0 \\
\hline Total & 11,300 & 100 & 36,100 & 100 & 47.400 & 55.4 \\
\hline SE & 38.6 & & 73.3 & & 55.4 & \\
\hline \multicolumn{7}{|c|}{ (In thousands of acres) } \\
\hline Land value increase & 229 & 8 & 0 & 0 & 229 & 60.3 \\
\hline Recreation & 0 & 0 & 153 & 29 & 153 & 73.2 \\
\hline Income from timber & 1,564 & 58 & 76 & 14 & 1,640 & 25.6 \\
\hline Farm and domestic us $\epsilon$ & 229 & 8 & 0 & 0 & 229 & 60.3 \\
\hline Esthetic enjoyment & 153 & 6 & 76 & 14 & 229 & 60.3 \\
\hline Other & 535 & 20 & 229 & 43 & 764 & 35.1 \\
\hline No answer & 0 & 0 & 0 & 0 & 0 & 0 \\
\hline Total & 2,710 & 100 & 535 & 100 & 3,245 & 0.8 \\
\hline SE & 8.1 & & 40.9 & & 0.8 & \\
\hline
\end{tabular}

W-fewer than 50 owners or less than 0.5 percent 


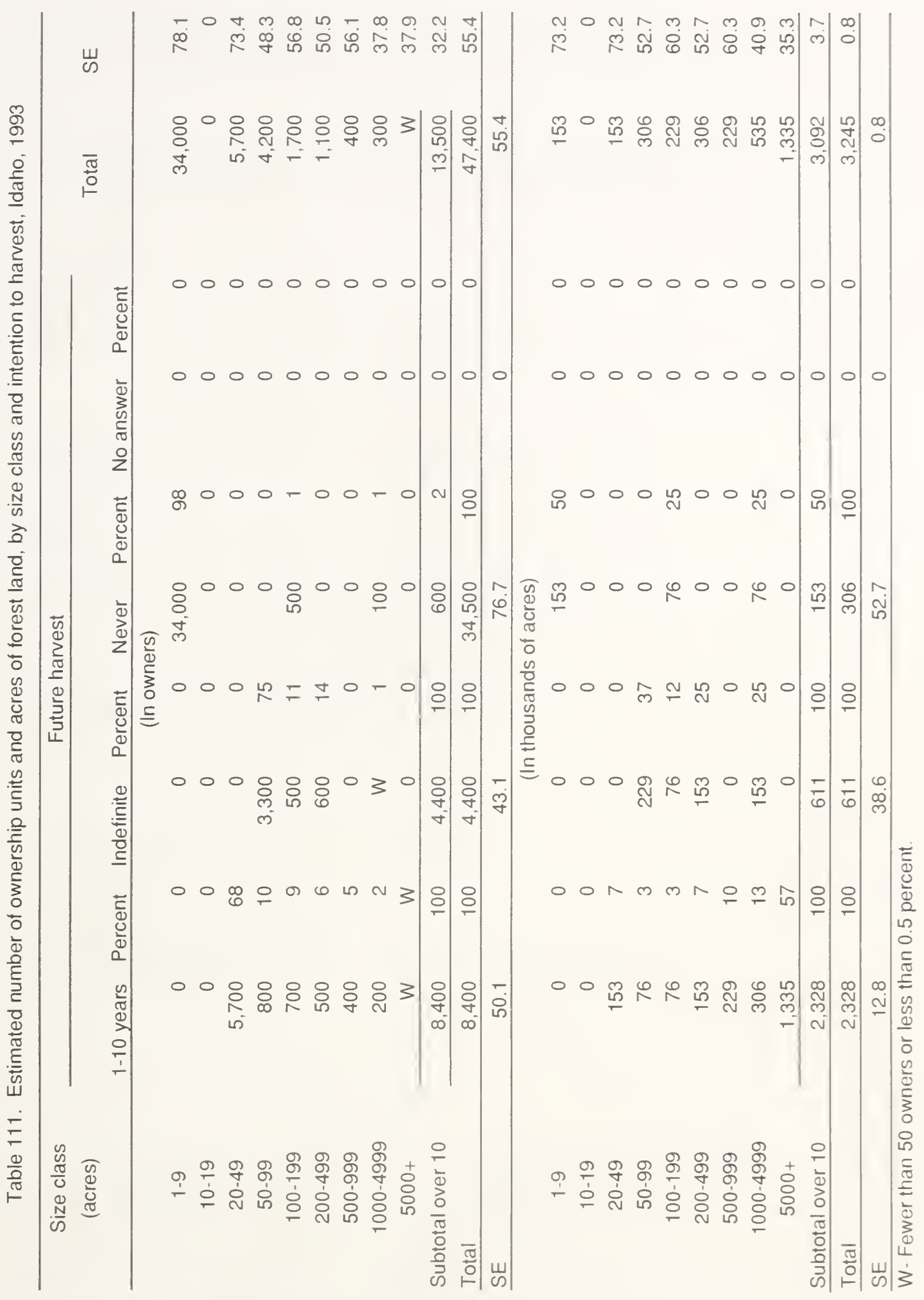




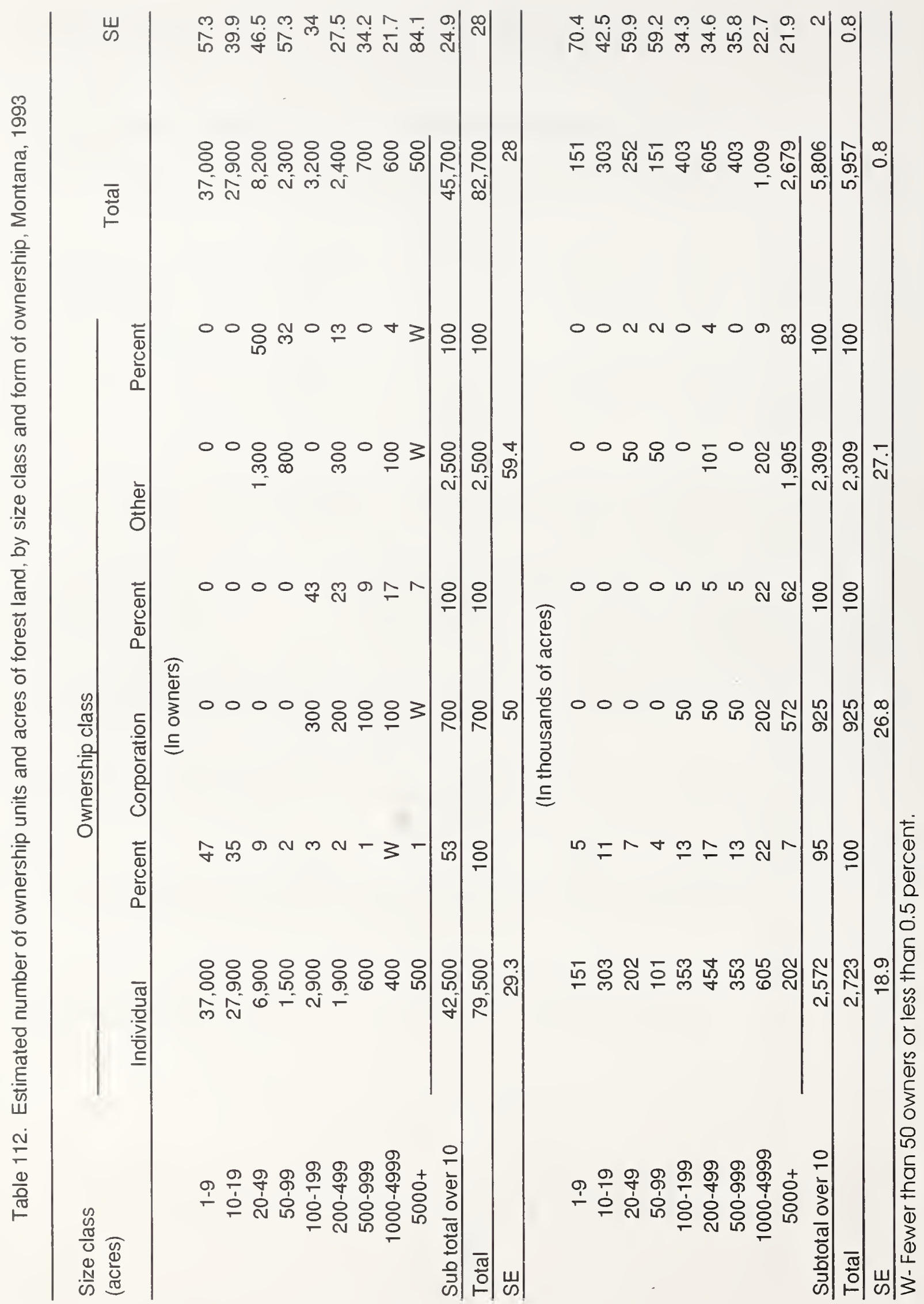


Table 113. Estimated number of ownership units and acres of forest land, by form of ownership and past harvest experience, Montana, 1993

\begin{tabular}{|c|c|c|c|c|c|c|}
\hline \multirow[t]{2}{*}{ Form of ownership } & \multicolumn{4}{|c|}{ Harvest experience } & \multirow{2}{*}{ Total } & \multirow{2}{*}{ SE } \\
\hline & Harvested & Percent & Did not harvest & Percent & & \\
\hline \multicolumn{7}{|c|}{ (In owners) } \\
\hline Individual + joint & 41,900 & 97 & 37,600 & 95 & 79,500 & 29.3 \\
\hline Partnership & 400 & 1 & 800 & 2 & 1,200 & 69.4 \\
\hline Corporation & 600 & 1 & 100 & W & 700 & 50 \\
\hline Other & W & $W$ & 1,300 & 3 & 1,300 & 95.2 \\
\hline Total & 42,900 & 100 & 39,800 & 100 & 82,700 & 28 \\
\hline SE & 45.2 & & 35.7 & & 28 & \\
\hline \multicolumn{7}{|c|}{ (In thousands of acres) } \\
\hline Individual + joint & 1,765 & 38 & 958 & 70 & 2,723 & 18.9 \\
\hline Partnership & 202 & 4 & 50 & 4 & 252 & 47.3 \\
\hline Corporation & 723 & 16 & 202 & 15 & 925 & 26.8 \\
\hline Other & 1,905 & 41 & 151 & 11 & 2,057 & 321 \\
\hline Total & 4,595 & 100 & 1,361 & 100 & 5,957 & 0.8 \\
\hline SE & 6.5 & & 21.8 & & 0.8 & \\
\hline
\end{tabular}

W-Fewer than 50 owners or less than 0.5 percent 
Table 114. Estimated number of ownership units and acres of forest land, by incorporated and unincorporated businesses and past harvest experience, Montana, 1993

\begin{tabular}{|c|c|c|c|c|c|c|}
\hline \multirow[t]{2}{*}{ Nature of business } & \multicolumn{4}{|c|}{ Hanvest } & \multirow{2}{*}{ Total } & \multirow{2}{*}{ SE } \\
\hline & Harvested & Percent & Did not harvest & Percent & & \\
\hline \multicolumn{7}{|c|}{ (In owners) } \\
\hline \multicolumn{7}{|l|}{ Incorporated: } \\
\hline Forest industry & W & W & 0 & 0 & W & 59.2 \\
\hline Farm & 600 & 1 & 100 & W & 700 & 52.4 \\
\hline Industrial business & W & W & 0 & 0 & W & 99.5 \\
\hline Real estate & 0 & 0 & W & W & W & 99.5 \\
\hline Other & 0 & 0 & 0 & 0 & 0 & 0 \\
\hline Total corporate & 600 & 1 & 100 & $W$ & 700 & 50 \\
\hline \multicolumn{7}{|l|}{ Unincorporated: } \\
\hline Forest industry & W & W & 0 & 0 & W & 62.1 \\
\hline Farm & 4,200 & 10 & 16,800 & 42 & 21,000 & 40.1 \\
\hline Misc. individual & 37,900 & 88 & 21,600 & 54 & 59,500 & 36.7 \\
\hline Real estate & W & W & 0 & 0 & W & 98.9 \\
\hline Other & 200 & W & 1,300 & 3 & 1,400 & 87.5 \\
\hline Total noncorporate & 42,300 & 99 & 39,799 & 100 & 82,000 & 28.3 \\
\hline Total & 42,900 & 100 & 39,800 & 100 & 82,700 & 28 \\
\hline SE & 45.2 & & 35.7 & & 28 & \\
\hline \multicolumn{7}{|c|}{ (In thousands of acres) } \\
\hline Incorporated: & & & & & & \\
\hline Forest industry & 199 & 4 & 0 & 0 & 199 & 63.8 \\
\hline Farm & 473 & 10 & 151 & 11 & 625 & 31.3 \\
\hline Industrial business & 50 & 1 & 0 & 0 & 50 & 100 \\
\hline Real estate & 0 & 0 & 50 & 4 & 50 & 100 \\
\hline Other & 0 & 0 & 0 & 0 & 0 & 0 \\
\hline Total corporate & 723 & 16 & 202 & 15 & 925 & 26.8 \\
\hline \multicolumn{7}{|l|}{ Unincorporated: } \\
\hline Forest industry & 1,284 & 28 & 0 & 0 & 1,284 & 62.7 \\
\hline Farm & 1,462 & 32 & 655 & 48 & 2,118 & 13.8 \\
\hline Misc. individual & 403 & 9 & 454 & 33 & 857 & 40.4 \\
\hline Real estate & 50 & 1 & 0 & 0 & 50 & 100 \\
\hline Other & 672 & 15 & 50 & 4 & 722 & 54.7 \\
\hline Total noncorporate & 3,872 & 84 & 1,160 & 85 & $\overline{5,032}$ & 5 \\
\hline Total & 4,595 & 100 & 1,361 & 100 & 5,957 & 0.8 \\
\hline SE & 6.5 & & 21.8 & & 0.8 & \\
\hline
\end{tabular}

W- Fewer than 50 owners or less than 0.5 percent 


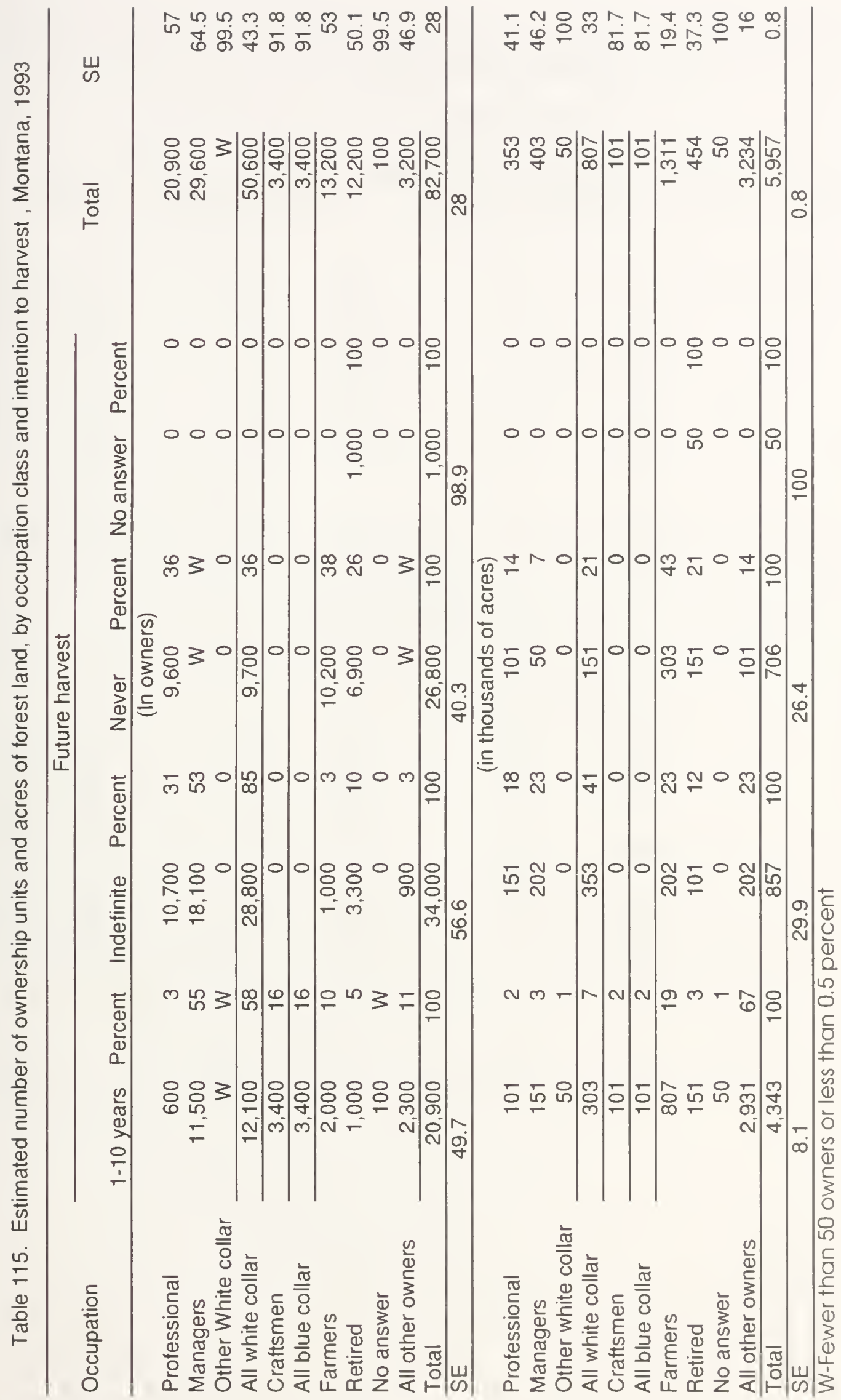


Table 116. Estimated number of ownership units and acres of forest land, by age class and past harvest experience, Montana, 1993

\begin{tabular}{|c|c|c|c|c|c|c|}
\hline \multirow[t]{2}{*}{ Age } & \multicolumn{4}{|c|}{ Harvest experience } & \multirow{2}{*}{ Total } & \multirow{2}{*}{ SE } \\
\hline & Harvested & Percent & Did not harvest & Percent & & \\
\hline \multicolumn{7}{|c|}{ (In owners) } \\
\hline Under 25 & 600 & 1 & 0 & 0 & 600 & 98.9 \\
\hline $25-34$ & 0 & 0 & 0 & 0 & 0 & 0 \\
\hline $35-44$ & 8,100 & 19 & 10,100 & 25 & 18,200 & 61.2 \\
\hline $45-54$ & 18,600 & 43 & 5,600 & 14 & 24,100 & 72 \\
\hline $55-64$ & 12,000 & 28 & 11,400 & 29 & 23,300 & 52.3 \\
\hline 65 or over & 2,500 & 6 & 10,600 & 27 & 13,200 & 46.5 \\
\hline All other owners & 1,000 & 2 & 2,200 & 5 & 3,200 & 46.9 \\
\hline Total & 42,900 & 100 & 39,800 & 100 & 82,700 & 28 \\
\hline SE & 45.2 & & 35.7 & & 28 & \\
\hline \multicolumn{7}{|c|}{ (In thousands of acres) } \\
\hline Under 25 & 50 & 1 & 0 & 0 & 50 & 100 \\
\hline $25-34$ & 0 & 0 & 0 & 0 & 0 & 0 \\
\hline $35-44$ & 252 & 5 & 50 & 4 & 303 & 45.3 \\
\hline $45-54$ & 353 & 8 & 303 & 22 & 655 & 27.8 \\
\hline $55-64$ & 504 & 11 & 252 & 19 & 756 & 27.9 \\
\hline 65 or over & 605 & 13 & 353 & 26 & 958 & 28.9 \\
\hline All other owners & 2,830 & 61 & 403 & 30 & 3,234 & 16 \\
\hline Total & 4,595 & 100 & 1,361 & 100 & 5,957 & 0.8 \\
\hline $\mathrm{SE}$ & 6.5 & & 21.8 & & 0.8 & \\
\hline
\end{tabular}


Table 117. Estimated number of ownership units and acres of forest land, by date of aquisition and form of ownership, Montana, 1993

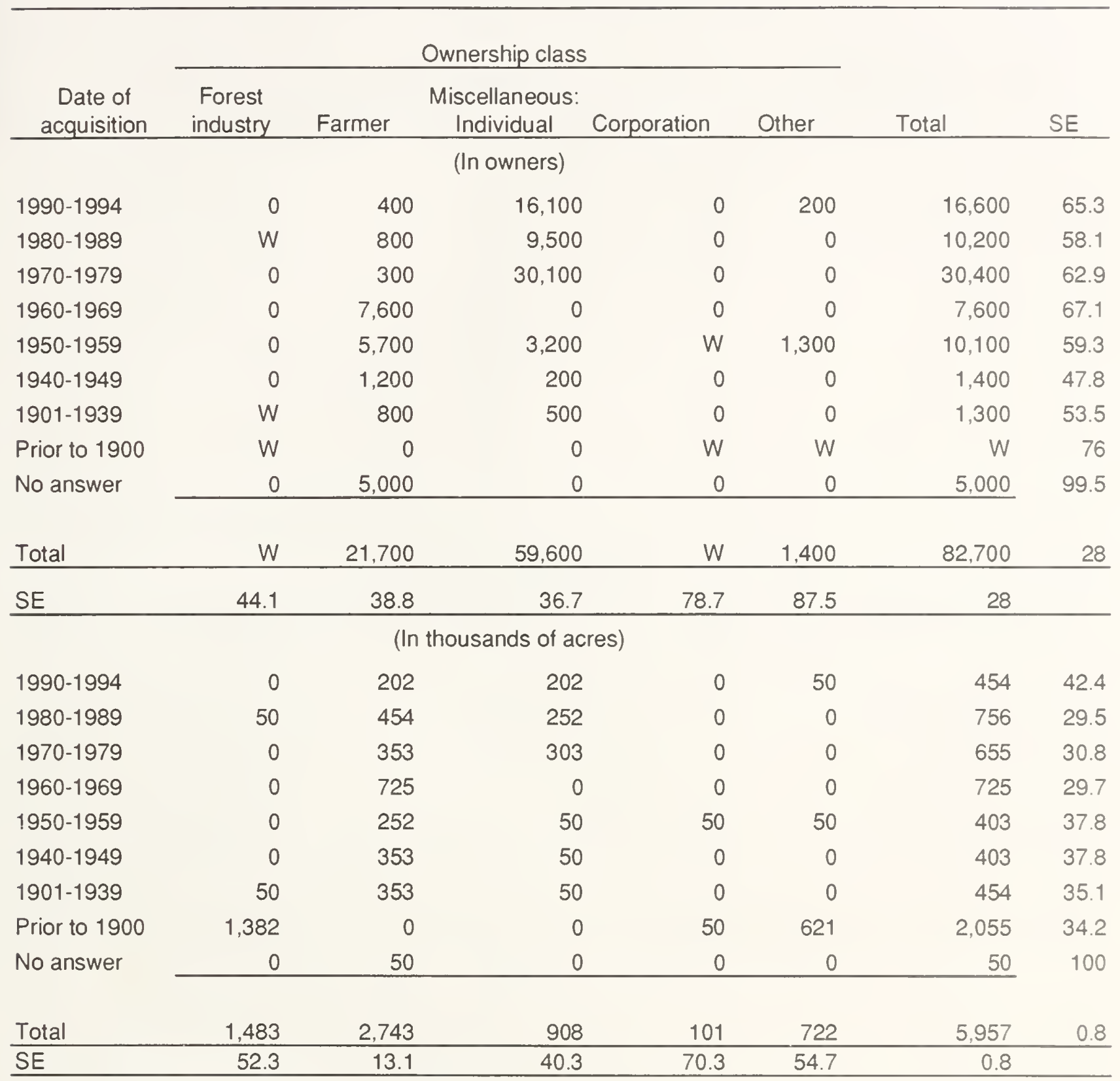

W-fewer than 50 owners or less than 0.5 percent 
Table 118. Estimated number of ownership units and acres of forest land, by distance from tracts, Montana, 1993

\begin{tabular}{|c|c|c|c|c|}
\hline \multirow[t]{3}{*}{ Distance } & \multicolumn{3}{|c|}{ Tracts } & \multirow{3}{*}{ Total } \\
\hline & \multirow[b]{2}{*}{1 tract } & \multicolumn{2}{|c|}{ More than one tract } & \\
\hline & & Nearest tract & Farthest tract & \\
\hline \multicolumn{5}{|c|}{ (In owners) } \\
\hline Less than 1 mile & 7,900 & 14,900 & 2,100 & \\
\hline $2-5$ miles & 27,100 & 100 & 5,700 & \\
\hline $6-15$ miles & 2,500 & 4,700 & 4,700 & \\
\hline $16-25$ miles & 200 & 200 & 0 & \\
\hline $26-50$ miles & 0 & W & 3,500 & \\
\hline $51-100$ miles & 800 & 300 & 500 & \\
\hline More than 100 miles & 23,200 & 300 & 4,000 & \\
\hline No answer & 200 & 200 & 200 & \\
\hline Total & 62,000 & 20,700 & 20,700 & 82,700 \\
\hline \multicolumn{5}{|c|}{ (In thousands of acres) } \\
\hline Less than 1 mile & 555 & 2,981 & 423 & \\
\hline 2-5 miles & 252 & 101 & 303 & \\
\hline $6-15$ miles & 252 & 202 & 252 & \\
\hline $16-25$ miles & 151 & 50 & 0 & \\
\hline $26-50$ miles & 0 & 151 & 252 & \\
\hline $51-100$ miles & 101 & 101 & 202 & \\
\hline More than 100 miles & 353 & 202 & 2,357 & \\
\hline No answer & 151 & 353 & 353 & \\
\hline Total & 1,815 & 4,142 & 4,142 & 5,957 \\
\hline
\end{tabular}

W-Fewer than 50 owners or less than 0.5 percent 
Table 119. Estimated number of ownership units and acres of forest land, by primary and secondary reason for owning forest land, Montana, 1993

\begin{tabular}{|c|c|c|c|c|}
\hline \multirow[t]{2}{*}{ Reason } & \multicolumn{2}{|c|}{ Primary reason } & \multicolumn{2}{|c|}{ Secondary reason } \\
\hline & Number & Percent & Number & Percent \\
\hline & \multicolumn{4}{|c|}{ (In owners) } \\
\hline Land investment & 2,100 & 3 & 6,300 & 8 \\
\hline Recreation & 1,300 & 2 & 12,500 & 15 \\
\hline Timber production & 200 & W & 1,100 & 1 \\
\hline Farm and domestic use & 6,700 & 8 & 300 & W \\
\hline Esthetic enjoyment & 17,500 & 21 & 5,200 & 6 \\
\hline Part of farm & 6,800 & 8 & 600 & 1 \\
\hline Part of residence & 14,800 & 18 & 5,200 & 6 \\
\hline Estate & 15,600 & 19 & 19,400 & 24 \\
\hline Other & 17,800 & 21 & 12,100 & 15 \\
\hline No secondary reason given & - & - & 20,000 & 24 \\
\hline No answer & 0 & 0 & 0 & 0 \\
\hline \multirow[t]{2}{*}{ Total } & 82,700 & 100 & 82,700 & 100 \\
\hline & \multicolumn{4}{|c|}{ (In thousands of acres) } \\
\hline Land investment & 202 & 3 & 151 & 3 \\
\hline Recreation & 303 & 5 & 875 & 14 \\
\hline Timber production & 1,685 & 28 & 555 & 9 \\
\hline Farm and domestic use & 403 & 7 & 151 & 3 \\
\hline Esthetic enjoyment & 454 & 8 & 252 & 4 \\
\hline Part of farm & 555 & 9 & 252 & 4 \\
\hline Part of residence & 353 & 6 & 151 & 3 \\
\hline Estate & 202 & 3 & 151 & 3 \\
\hline Other & 1,801 & 30 & 336 & 6 \\
\hline No secondary reason given & - & - & 3,082 & 51 \\
\hline No answer & 0 & $\underline{0}$ & 0 & 0 \\
\hline Total & 5,957 & 100 & 5,957 & 100 \\
\hline
\end{tabular}

W-Fewer than 50 owners or less than 0.5 percent 
Table 120. Estimated number of ownership units and acres of forest land, by primary benefit expected in the next 10 years and past harvest experience, Montana, 1993

\begin{tabular}{|c|c|c|c|c|c|c|}
\hline \multirow[t]{2}{*}{ Benefits expected } & \multicolumn{4}{|c|}{ Harvest Experience } & \multirow{2}{*}{ Total } & \multirow{2}{*}{ SE } \\
\hline & Harvested & Percent & Did not harvest & Percent & & \\
\hline \multicolumn{7}{|c|}{ (In owners) } \\
\hline Land value increase & 4,700 & 11 & 1,200 & 3 & 5,900 & 57.6 \\
\hline Recreation & 2.600 & 6 & 700 & 2 & 3,300 & 47.9 \\
\hline Income from timber & 200 & W & 100 & W & 300 & 69.8 \\
\hline Farm and domestic us $\epsilon$ & 1,000 & 2 & 5,100 & 13 & 6,200 & 81.4 \\
\hline Esthetic enjoyment & 21,900 & 51 & 14,800 & 37 & 36,700 & 53.2 \\
\hline Firewood & 600 & 1 & 0 & 0 & 600 & 98.9 \\
\hline Other & 11,900 & 28 & 6,500 & 16 & 18,400 & 60.9 \\
\hline No answer & W & W & 11,400 & 29 & 11,500 & 62.4 \\
\hline Total & 42,900 & 100 & 39,800 & 100 & 82,700 & 28 \\
\hline SE & 45.2 & & 35.7 & & 28 & \\
\hline \multicolumn{7}{|c|}{ (In thousands of acres) } \\
\hline Land value increase & 252 & 5 & 151 & 11 & 403 & 35.8 \\
\hline Recreation & 353 & 8 & 151 & 11 & 504 & 34.8 \\
\hline Income from timber & 1.685 & 37 & 50 & 4 & 1,736 & 44.1 \\
\hline Farm and domestic us $\epsilon$ & 353 & 8 & 151 & 11 & 504 & 32.9 \\
\hline Esthetic enjoyment & 403 & 9 & 403 & 30 & 807 & 34.8 \\
\hline Firewood & 50 & 1 & 0 & 0 & 50 & 100 \\
\hline Other & 1,448 & 31 & 303 & 22 & 1.750 & 26.6 \\
\hline No answer & 50 & 1 & 151 & 11 & 202 & 50.6 \\
\hline Total & 4,595 & 100 & 1,361 & 100 & 5,957 & 0.8 \\
\hline$\overline{\mathrm{SE}}$ & 6.5 & & 21.8 & & 0.8 & \\
\hline
\end{tabular}

W-fewer than 50 owners or less than 0.5 percent 


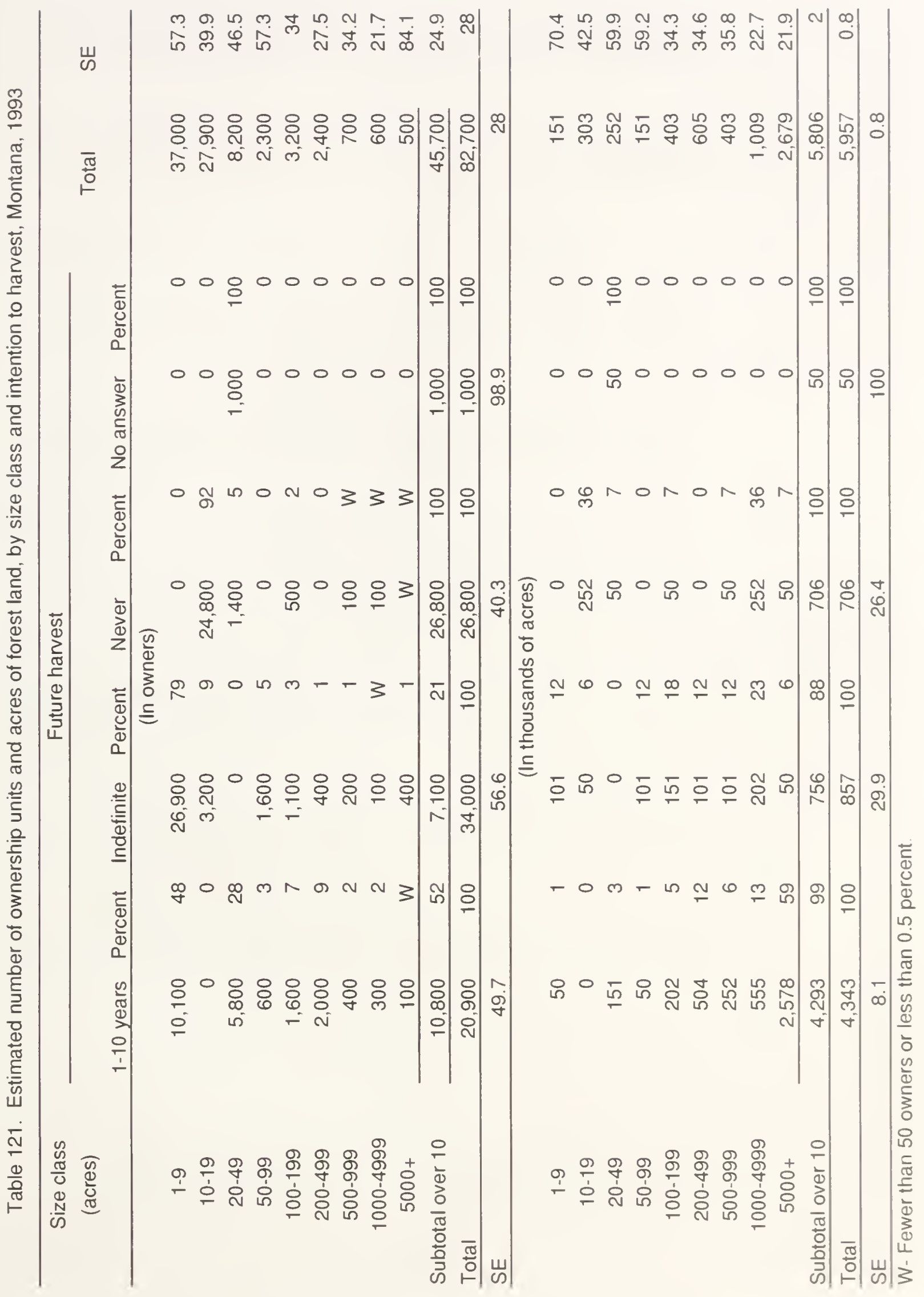




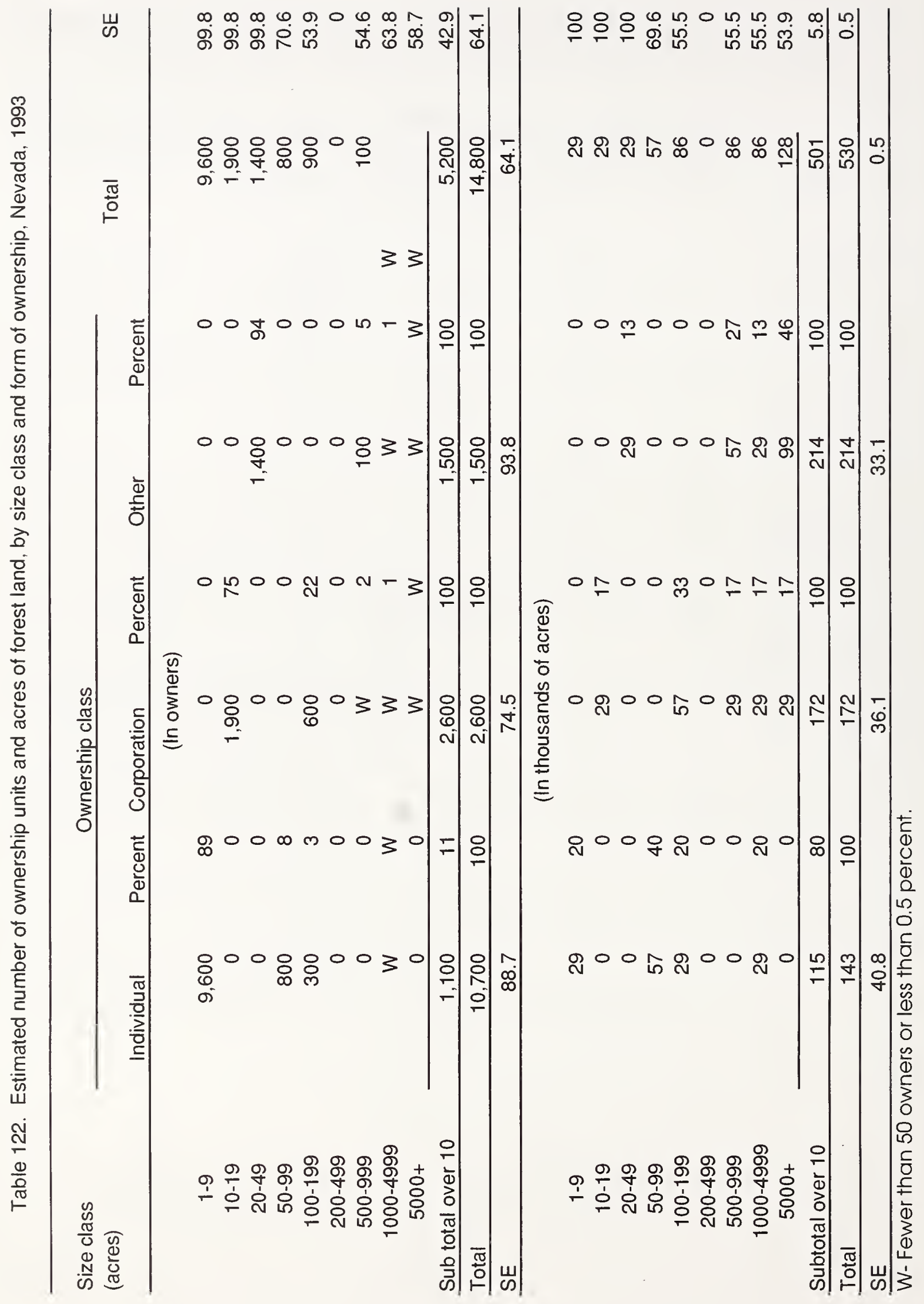


Table 123. Estimated number of ownership units and acres of forest land, by form of ownership and past harvest experience, Nevada, 1993

Form of ownership

Harvest experience

Total

SE

Harvested Percent Did not harvest Percent

(In owners)

\begin{tabular}{|c|c|c|c|c|c|c|}
\hline Individual + joint & 10,400 & 94 & 300 & 8 & 10,700 & 88.7 \\
\hline Partnership & W & W & 1,500 & 1500 & 1,500 & 94.8 \\
\hline Corporation & 600 & 5 & 2,000 & 2000 & 2,600 & 74.5 \\
\hline Other & W & W & W & W & $W$ & 75.3 \\
\hline Total & 11,000 & 100 & 3,800 & 100 & 14,800 & 64.1 \\
\hline SE & 86.1 & & 60.8 & & 64.1 & \\
\hline \multicolumn{7}{|c|}{ (In thousands of acres) } \\
\hline Individual + joint & 86 & 37 & 57 & 19 & 143 & 40.8 \\
\hline Partnership & 29 & 12 & 57 & 19 & 86 & 55.5 \\
\hline Corporation & 86 & 37 & 86 & 29 & 172 & 36.1 \\
\hline Other & 29 & 12 & 99 & 33 & 128 & 53.9 \\
\hline Total & 230 & 100 & 300 & 100 & 530 & 0.5 \\
\hline SE & 29.4 & & 22.5 & & 0.5 & \\
\hline
\end{tabular}

W-Fewer than 50 owners or less than 0.5 percent 
Table 124. Estimated number of ownership units and acres of forest land, by incorporated and unincorporated businesses and past harvest experience, Nevada, 1993

\begin{tabular}{|c|c|c|c|c|c|c|}
\hline \multirow[t]{2}{*}{ Nature of business } & \multicolumn{4}{|c|}{ Harvest } & \multirow{2}{*}{ Total } & \multirow{2}{*}{ SE } \\
\hline & Harvested & Percent & Did not harvest & Percent & & \\
\hline \multicolumn{7}{|c|}{ (In owners) } \\
\hline $\begin{array}{l}\text { Incorporated: } \\
\text { Farm }\end{array}$ & & 3 & ח ח ח & $5 ?$ & ח ? ? ? & 851 \\
\hline Real estate & 300 & 3 & $\begin{array}{r}2,000 \\
0\end{array}$ & $\begin{array}{r}52 \\
0\end{array}$ & $\begin{array}{r}2,200 \\
300\end{array}$ & $\begin{array}{l}85.1 \\
99.8\end{array}$ \\
\hline Other & 0 & 0 & W & 1 & W & 99.8 \\
\hline Total corporate & 600 & 5 & 2,000 & 53 & 2,600 & 74.5 \\
\hline \multicolumn{7}{|l|}{ Unincorporated: } \\
\hline Farm & 900 & 8 & 1,800 & 47 & 2,600 & 56.4 \\
\hline Misc. individual & 9,600 & 87 & 0 & 0 & 9,600 & 99.8 \\
\hline Other & 0 & 0 & W & W & W & 91.7 \\
\hline Total noncorporate & 10,400 & 95 & 1,800 & 47 & 12,200 & 77.7 \\
\hline Total & 11,000 & 100 & 3,800 & 100 & 14,800 & 64.1 \\
\hline SE & 86.1 & & 60.8 & & 64.1 & \\
\hline \multicolumn{7}{|c|}{ (In thousands of acres) } \\
\hline Incorporated: & & & & & & \\
\hline Farm & 57 & 25 & 57 & 19 & 115 & 46.8 \\
\hline Real estate & 29 & 12 & 0 & 0 & 29 & 100 \\
\hline Other & 0 & 0 & 29 & 9 & 29 & 100 \\
\hline Total corporate & 86 & 37 & 86 & 29 & 172 & 36.1 \\
\hline \multicolumn{7}{|l|}{ Unincorporated: } \\
\hline Farm & 115 & 50 & 115 & 38 & 230 & 29.4 \\
\hline Misc. individual & 29 & 12 & 0 & 0 & 29 & 100 \\
\hline Other & 0 & 0 & 99 & 33 & 99 & 67.8 \\
\hline Total noncorporate & 143 & 63 & 214 & 71 & 358 & 17.4 \\
\hline Total & 230 & 100 & 300 & 100 & 530 & 0.5 \\
\hline SE & 29.4 & & 22.5 & & 0.5 & \\
\hline
\end{tabular}

W- Fewer than 50 owners or less than 0.5 percent 


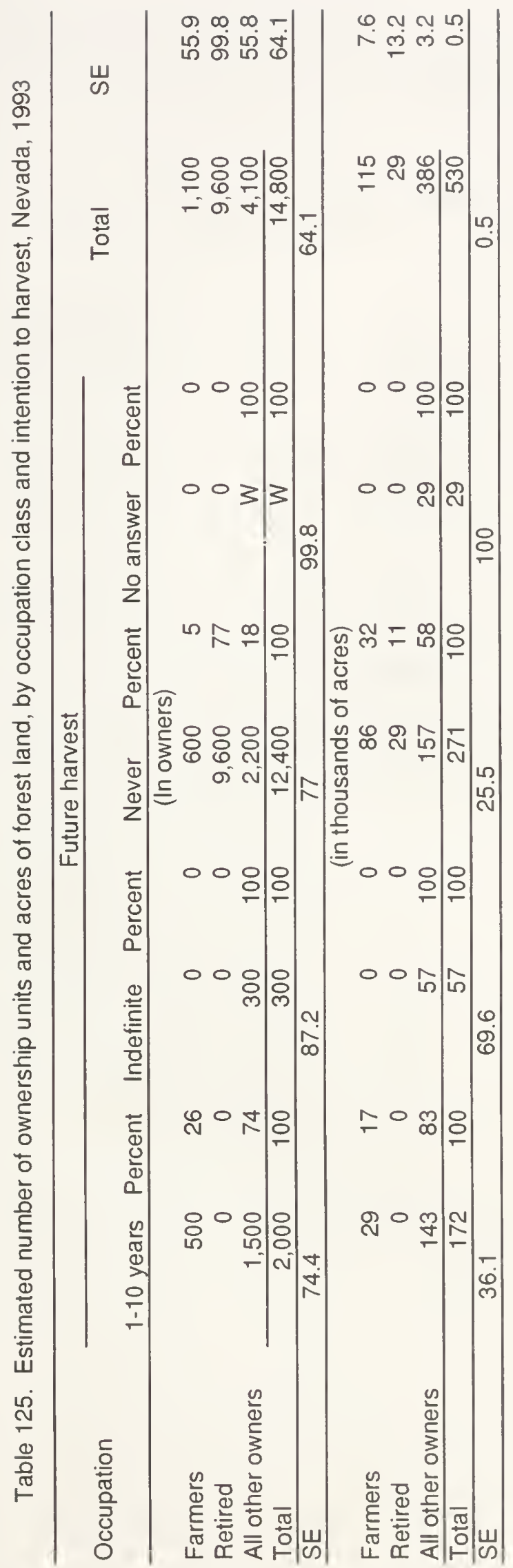


Table 126. Estimated number of ownership units and acres of forest land, by age class and past harvest experience, Nevada, 1993

\begin{tabular}{|c|c|c|c|c|c|c|}
\hline \multirow[t]{2}{*}{ Age } & \multicolumn{4}{|c|}{ Harvest experience } & \multirow{2}{*}{ Total } & \multirow{2}{*}{ SE } \\
\hline & Harvested & Percent & Did not harvest & Percent & & \\
\hline \multicolumn{7}{|c|}{ (In owners) } \\
\hline $55-64$ & 9,900 & 90 & 300 & 8 & 10,200 & 93.5 \\
\hline 65 or over & 500 & 5 & 0 & 0 & 500 & 99.8 \\
\hline All other owners & 600 & 5 & 3,500 & 92 & 4,100 & 55.8 \\
\hline Total & 11,000 & 100 & 3,800 & 100 & 14,800 & 64.1 \\
\hline SE & 86.1 & & 60.8 & & 64.1 & \\
\hline \multicolumn{7}{|c|}{ (In thousands of acres) } \\
\hline $55-64$ & 57 & 25 & 57 & 19 & 115 & 46.8 \\
\hline 65 or over & 29 & 12 & 0 & 0 & 29 & 100 \\
\hline All other owners & 143 & 62 & 243 & 81 & 386 & 15.2 \\
\hline Total & 230 & 100 & 300 & 100 & 530 & 0.5 \\
\hline SE & 29.4 & & 22.5 & & 0.5 & \\
\hline
\end{tabular}


Table 127. Estimated number of ownership units and acres of forest land, by date of aquisition and form of ownership, Nevada, 1993

\begin{tabular}{|c|c|c|c|c|c|c|c|}
\hline \multirow[b]{2}{*}{$\begin{array}{c}\text { Date of } \\
\text { acquisition }\end{array}$} & \multicolumn{5}{|c|}{ Ownership class } & \multirow[b]{2}{*}{ Total } & \multirow[b]{2}{*}{ SE } \\
\hline & $\begin{array}{c}\text { Forest } \\
\text { industry }\end{array}$ & Farmer & $\begin{array}{l}\text { Miscellaneous: } \\
\text { Individual }\end{array}$ & Corporation & Other & & \\
\hline \multicolumn{8}{|c|}{ (In owners) } \\
\hline 1990-1994 & 0 & 0 & 0 & 0 & 0 & 0 & 0 \\
\hline 1980-1989 & 0 & W & 0 & 0 & 0 & W & 99.8 \\
\hline 1970-1979 & 0 & 1,800 & 9,600 & W & 0 & 11,400 & 83.8 \\
\hline 1960-1969 & 0 & 2,200 & 0 & 0 & 0 & 2,200 & 86.9 \\
\hline $1950-1959$ & 0 & 600 & 0 & 0 & 0 & 600 & 92.2 \\
\hline $1940-1949$ & 0 & 0 & 0 & 0 & 0 & 0 & 0 \\
\hline $1901-1939$ & 0 & 300 & 0 & 0 & W & 300 & 95.8 \\
\hline Prior to 1900 & 0 & $W$ & 0 & 300 & W & 300 & 98.4 \\
\hline No answer & 0 & $W$ & 0 & 0 & 0 & $W$ & 99.8 \\
\hline Total & 0 & 4,900 & 9,600 & 300 & W & 14,800 & 64.1 \\
\hline SE & 0 & 46.4 & 99.8 & 90.4 & 91.7 & 64.1 & \\
\hline \multicolumn{8}{|c|}{ (In thousands of acres) } \\
\hline 1990-1994 & 0 & 0 & 0 & 0 & 0 & 0 & 0 \\
\hline 1980-1989 & 0 & 29 & 0 & 0 & 0 & 29 & 100 \\
\hline $1970-1979$ & 0 & 115 & 29 & 29 & 0 & 172 & 36.1 \\
\hline 1960-1969 & 0 & 57 & 0 & 0 & 0 & 57 & 69.6 \\
\hline $1950-1959$ & 0 & 57 & 0 & 0 & 0 & 57 & 69.6 \\
\hline $1940-1949$ & 0 & 0 & 0 & 0 & 0 & 0 & 0 \\
\hline 1901-1939 & 0 & 29 & 0 & 0 & 29 & 57 & 69.6 \\
\hline Prior to 1900 & 0 & 29 & 0 & 29 & 70 & 128 & 53.9 \\
\hline No answer & 0 & 29 & 0 & 0 & 0 & 29 & 100 \\
\hline Total & 0 & 345 & 29 & 57 & 99 & 530 & 0.5 \\
\hline SE & 0 & 20.5 & 100 & 69.6 & 67.8 & 0.5 & \\
\hline
\end{tabular}

W-fewer than 50 owners or less than 0.5 percent 
Table 128. Estimated number of ownership units and acres of forest land, by distance from tracts, Nevada, 1993

\begin{tabular}{|c|c|c|c|c|}
\hline \multirow{3}{*}{ Distance } & \multicolumn{3}{|c|}{ Tracts } & \multirow{3}{*}{ Total } \\
\hline & \multirow[b]{2}{*}{1 tract } & \multicolumn{2}{|c|}{ More than one tract } & \\
\hline & & Nearest tract & Farthest tract & \\
\hline \multicolumn{5}{|c|}{ (In owners) } \\
\hline Less than 1 mile & 11,300 & 0 & 0 & \\
\hline 2-5 miles & 0 & W & W & \\
\hline $6-15$ miles & 800 & W & W & \\
\hline $16-25$ miles & 0 & 2,000 & 0 & \\
\hline 26-50 miles & 0 & 300 & 2,200 & \\
\hline $51-100$ miles & 0 & 0 & 0 & \\
\hline More than 100 miles & 0 & 0 & W & \\
\hline No answer & 300 & W & $W$ & \\
\hline Total & 12,400 & 2,400 & 2,400 & 14,800 \\
\hline \multicolumn{5}{|c|}{ (In thousands of acres) } \\
\hline Less than 1 mile & 86 & 0 & 0 & \\
\hline $2-5$ miles & 0 & 29 & 29 & \\
\hline $6-15$ miles & 57 & 29 & 29 & \\
\hline $16-25$ miles & 0 & 57 & 0 & \\
\hline $26-50$ miles & 0 & 57 & 86 & \\
\hline $51-100$ miles & 0 & 0 & 0 & \\
\hline More than 100 miles & 0 & 0 & 29 & \\
\hline No answer & 57 & 157 & 157 & \\
\hline Total & 201 & 329 & 329 & 530 \\
\hline
\end{tabular}


Table 129. Estimated number of ownership units and acres of forest land, by primary and secondary reason for owning forest land, Nevada, 1993

\begin{tabular}{|c|c|c|c|c|}
\hline \multirow[t]{2}{*}{ Reason } & \multicolumn{2}{|c|}{ Primary reason } & \multicolumn{2}{|c|}{ Secondary reason } \\
\hline & Number & Percent & Number & Percent \\
\hline & \multicolumn{4}{|c|}{ (In owners) } \\
\hline Land investment & 300 & 2 & 0 & 0 \\
\hline Recreation & W & $W$ & 600 & 4 \\
\hline Timber production & 0 & 0 & 0 & 0 \\
\hline Farm and domestic use & 500 & 3 & 0 & 0 \\
\hline Esthetic enjoyment & 0 & 0 & 0 & 0 \\
\hline Part of farm & 2,300 & 16 & 0 & 0 \\
\hline Part of residence & 9.600 & 65 & 0 & 0 \\
\hline Estate & 0 & 0 & 0 & 0 \\
\hline Other & 2,000 & 14 & W & W \\
\hline No secondary reason given & - & - & 14,200 & 96 \\
\hline No answer & 0 & 0 & 0 & 0 \\
\hline \multirow[t]{2}{*}{ Total } & 14,800 & 100 & 14,800 & 100 \\
\hline & \multicolumn{4}{|c|}{ (In thousands of acres) } \\
\hline Land investment & 29 & 5 & 0 & 0 \\
\hline Recreation & 29 & 5 & 86 & 16 \\
\hline Timber production & 0 & 0 & 0 & 0 \\
\hline Farm and domestic use & 29 & 5 & 0 & 0 \\
\hline Esthetic enjoyment & 0 & 0 & 0 & 0 \\
\hline Part of farm & 143 & 27 & 0 & 0 \\
\hline Part of residence & 29 & 5 & 0 & 0 \\
\hline Estate & 0 & 0 & 0 & 0 \\
\hline Other & 271 & 51 & 57 & 11 \\
\hline No secondary reason given & - & - & 386 & 73 \\
\hline No answer & 0 & 0 & 0 & 0 \\
\hline Total & 530 & 100 & 530 & 100 \\
\hline
\end{tabular}

W-Fewer than 50 owners or less than 0.5 percent 
Table 130. Estimated number of ownership units and acres of forest land, by primary benefit expected in the next 10 years and past harvest experience, Nevada, 1993

Benefits expected Harvest Experience Harvested Percent Did not harvest Percent

Total SE (In owners)

\begin{tabular}{|c|c|c|c|c|c|c|}
\hline Land value increase & 300 & 3 & 0 & 0 & 300 & 99.8 \\
\hline Recreation & 0 & 0 & W & 1 & W & 99.8 \\
\hline Income from timber & 500 & 5 & 0 & 0 & 500 & 99.8 \\
\hline Farm and domestic use & 300 & 3 & 1,700 & 46 & 2,000 & 71.7 \\
\hline Esthetic enjoyment & 0 & 0 & 0 & 0 & 0 & 0 \\
\hline Firewood & 0 & 0 & 0 & 0 & 0 & 0 \\
\hline Other & 0 & 0 & 0 & 0 & 0 & 0 \\
\hline No answer & 9,900 & 89 & 2,000 & 53 & 11,900 & 80.4 \\
\hline Total & 11,000 & 100 & 3,800 & 100 & 14,800 & 64.1 \\
\hline SE & 86.1 & & 60.8 & & 64.1 & \\
\hline \multicolumn{7}{|c|}{ (In thousands of acres) } \\
\hline Land value increase & 29 & 12 & 0 & 0 & 29 & 100 \\
\hline Recreation & 0 & 0 & 29 & 9 & 29. & 100 \\
\hline Income from timber & 29 & 12 & 0 & 0 & 29 & 100 \\
\hline Farm and domestic us $\epsilon$ & 29 & 12 & 86 & 29 & 115 & 46.8 \\
\hline Esthetic enjoyment & 0 & 0 & 0 & 0 & 0 & 0 \\
\hline Firewood & 0 & 0 & 0 & 0 & 0 & 0 \\
\hline Other & 0 & 0 & 0 & 0 & 0 & 0 \\
\hline No answer & 143 & 62 & 185 & 62 & 329 & 19.8 \\
\hline Total & 230 & 100 & 300 & 100 & 530 & 0.5 \\
\hline SE & 29.4 & & 22.5 & & 0.5 & \\
\hline
\end{tabular}

W-Fewer than 50 owners or less than 0.5 percent 


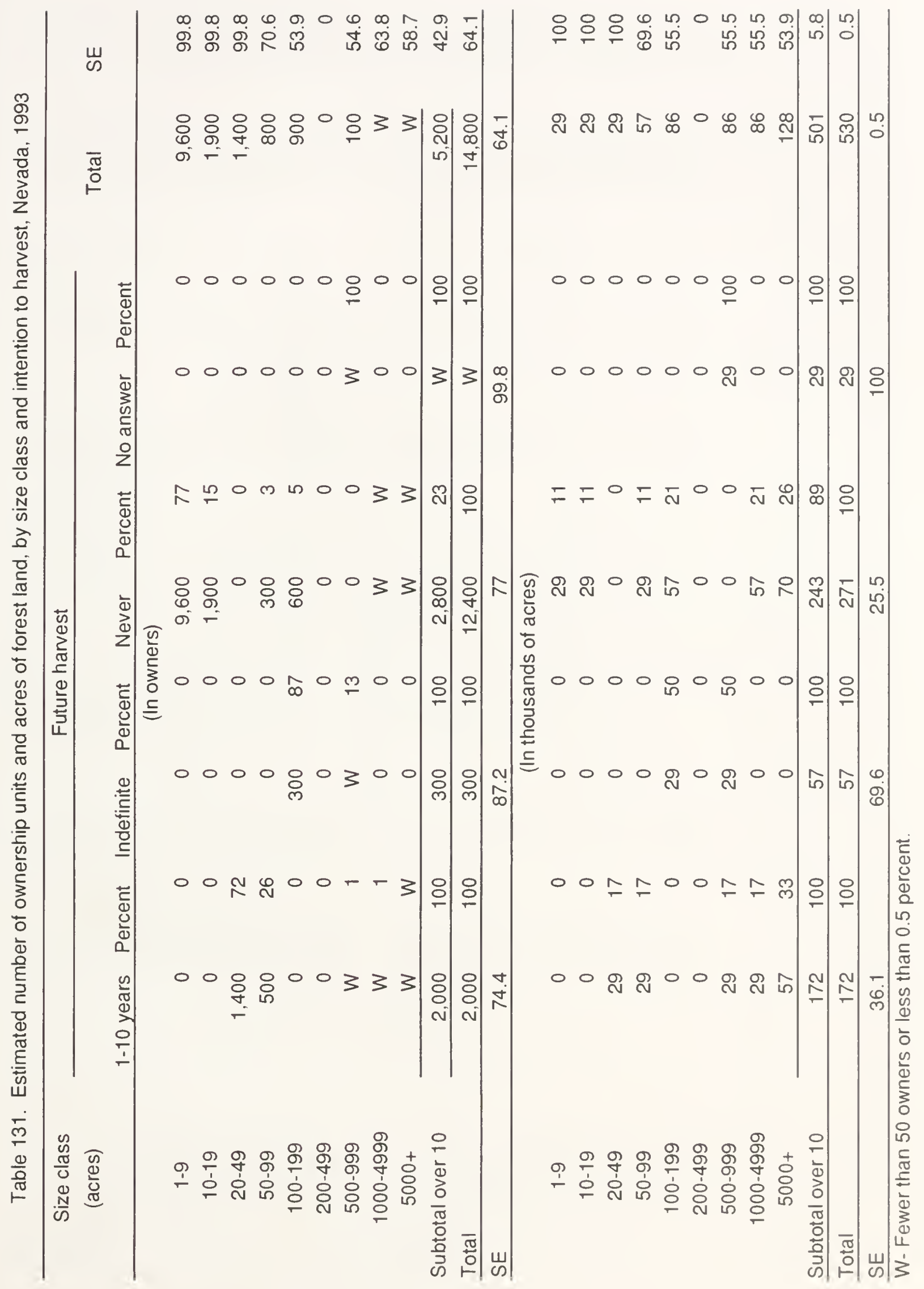




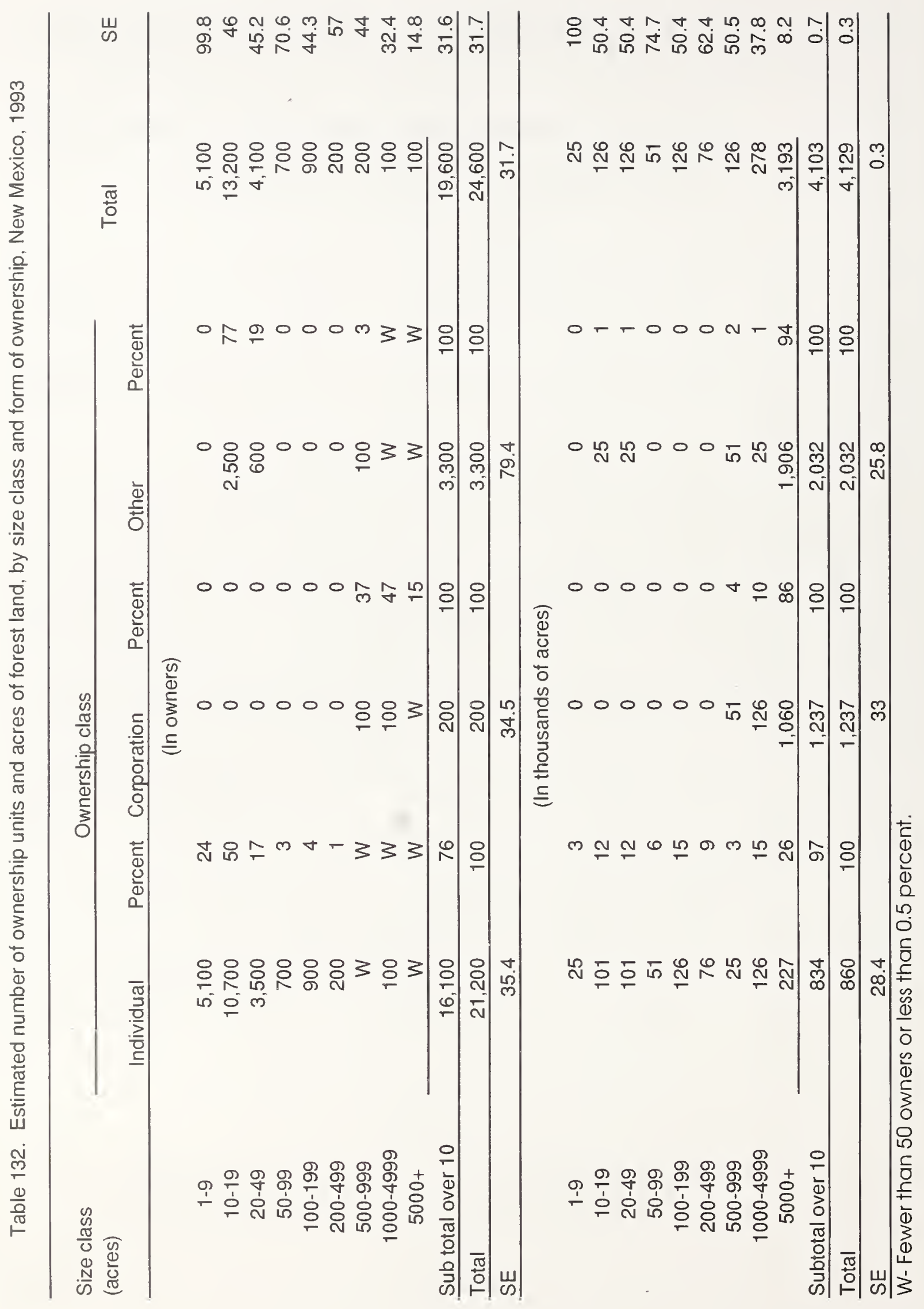


Table 133. Estimated number of ownership units and acres of forest land, by form of ownership and past harvest experience, New Mexico, 1993

\begin{tabular}{|c|c|c|c|c|c|c|}
\hline \multirow[t]{2}{*}{ Form of ownership } & \multicolumn{4}{|c|}{ Harvest experience } & \multirow{2}{*}{ Total } & \multirow{2}{*}{ SE } \\
\hline & Harvested & Percent & Did not harvest & Percent & & \\
\hline \multicolumn{7}{|c|}{ (In owners) } \\
\hline Individual + joint & 8,800 & 98 & 12,400 & 79 & 21,200 & 35.4 \\
\hline Partnership & W & W & 3,200 & 21 & 3,300 & 79.7 \\
\hline Corporation & 100 & 1 & W & $w$ & 200 & 34.5 \\
\hline Other & W & W & 0 & 0 & W & 29.2 \\
\hline Total & 9,000 & 100 & 15,700 & 100 & 24,600 & 31.7 \\
\hline SE & 62.8 & & 36.8 & & 31.7 & \\
\hline \multicolumn{7}{|c|}{ (In thousands of acres) } \\
\hline Individual + joint & 455 & 13 & 405 & 64 & 860 & 28.4 \\
\hline Partnership & 51 & 1 & 101 & 16 & 152 & 46.9 \\
\hline Corporation & 1,110 & 32 & 126 & 20 & 1,237 & 33 \\
\hline Other & 1,880 & 54 & 0 & 0 & 1,880 & 29.2 \\
\hline Total & 3,496 & 100 & 632 & 100 & 4,129 & 0.3 \\
\hline SE & 5.5 & & 30.3 & & 0.3 & \\
\hline
\end{tabular}

W-Fewer than 50 owners or less than 0.5 percent 
Table 134. Estimated number of ownership units and acres of forest land, by incorporated and unincorporated businesses and past harvest experience, New Mexico, 1993

\begin{tabular}{|c|c|c|c|c|c|c|}
\hline \multirow[t]{2}{*}{ Nature of business } & \multicolumn{4}{|c|}{ Harvest } & \multirow{2}{*}{ Total } & \multirow{2}{*}{ SE } \\
\hline & Harvested & Percent & Did not harvest & Percent & & \\
\hline \multicolumn{7}{|c|}{ (In owners) } \\
\hline \multicolumn{7}{|l|}{ Incorporated: } \\
\hline Farm & 100 & 1 & W & W & 100 & 42.9 \\
\hline Industrial business & W & W & 0 & 0 & W & 99.8 \\
\hline Real estate & W & W & 0 & 0 & W & 99.8 \\
\hline Sport/ recreation club & W & W & 0 & 0 & W & 99.8 \\
\hline Other & W & W & 0 & 0 & W & 99.8 \\
\hline Total corporate & 100 & 1 & $W$ & $W$ & 200 & 34.5 \\
\hline \multicolumn{7}{|l|}{ Unincorporated: } \\
\hline Forest industry & W & $W$ & 0 & 0 & W & 80.3 \\
\hline Farm & 2,900 & 33 & 3,000 & 19 & 5,900 & 49.9 \\
\hline Misc. individual & 5,900 & 66 & 9,400 & 60 & 15,300 & 46.2 \\
\hline Industrial business & 0 & 0 & 100 & 1 & 100 & 70.1 \\
\hline Other & W & W & 3,200 & 20 & 3,200 & 81.9 \\
\hline Total noncorporate & 8,800 & 99 & 15,600 & 100 & 24,400 & 32 \\
\hline Total & 9,000 & 100 & 15,700 & 100 & 24,600 & 31.7 \\
\hline SE & 62.8 & & 36.8 & & 31.7 & \\
\hline \multicolumn{7}{|c|}{ (In thousands of acres) } \\
\hline Incorporated: & & & & & & \\
\hline Farm & 754 & 21 & 126 & 20 & 880 & 38.8 \\
\hline Industrial business & 25 & 1 & 0 & 0 & 25 & 100 \\
\hline Real estate & 25 & 1 & 0 & 0 & 25 & 100 \\
\hline Sport/ recreation club & 51 & 1 & 0 & 0 & 51 & 74.5 \\
\hline Other & 255 & 7 & 0 & 0 & 255 & 89.1 \\
\hline Total corporate & 1,110 & 32 & 126 & 20 & 1,237 & 33 \\
\hline \multicolumn{7}{|l|}{ Unincorporated: } \\
\hline Forest industry & 700 & 20 & 0 & 0 & 700 & 85.6 \\
\hline Farm & 515 & 15 & 253 & 40 & 768 & 29.1 \\
\hline Misc. individual & 76 & 2 & 152 & 24 & 227 & 40.4 \\
\hline Nonindustrial business & 0 & 0 & 51 & 8 & 51 & 74.7 \\
\hline Other & 1,095 & 31 & 51 & 8 & 1,146 & 43.9 \\
\hline Total noncorporate & 2,386 & 68 & 506 & 80 & 2,892 & 14.1 \\
\hline Total & 3,496 & 100 & 632 & 100 & 4,129 & 0.3 \\
\hline SE & 5.5 & & 30.3 & & 0.3 & \\
\hline
\end{tabular}

W- Fewer than 50 owners or less than 0.5 percent 


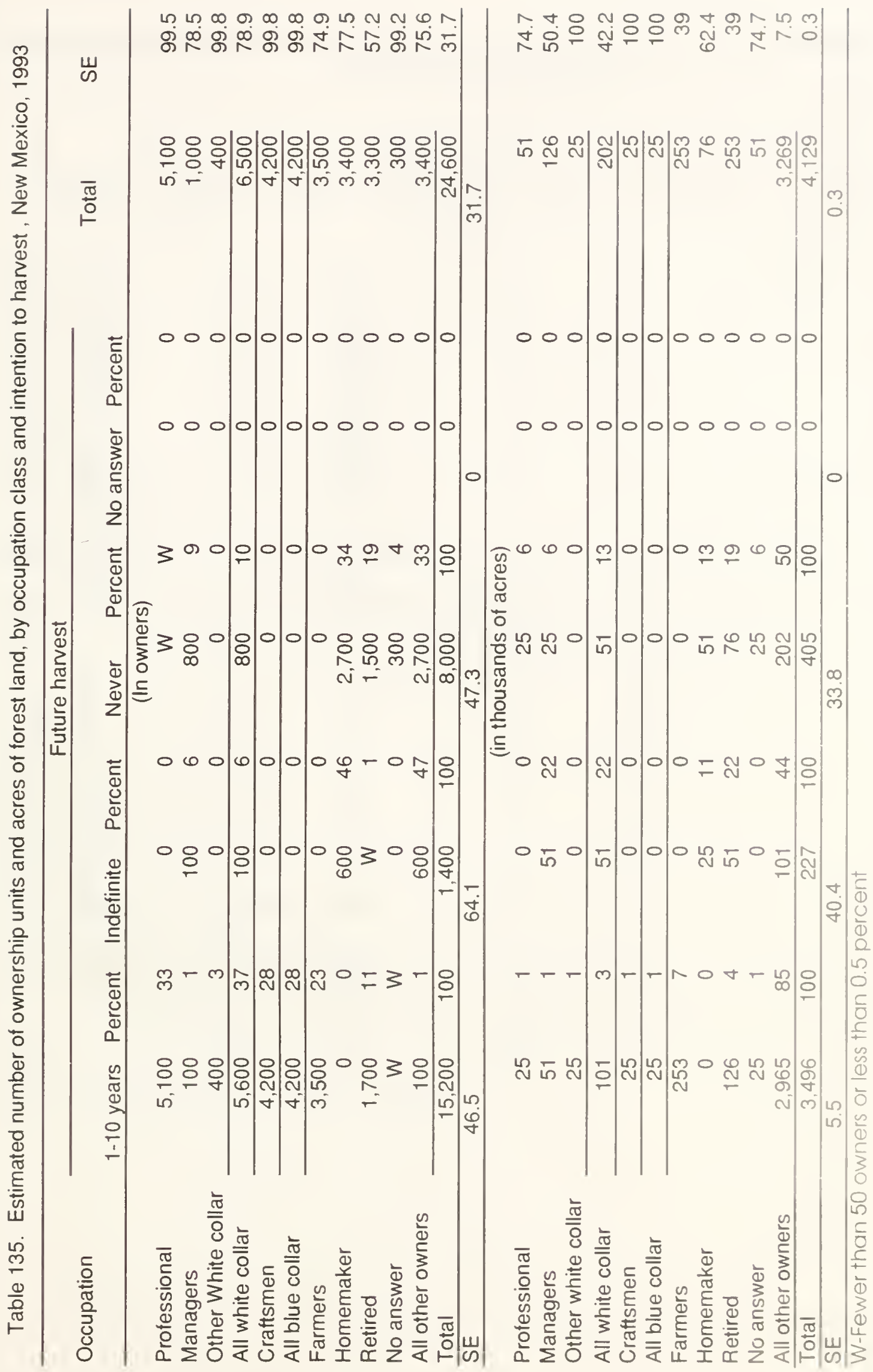


Table 136. Estimated number of ownership units and acres of forest land, by age class and past harvest experience, New Mexico, 1993

\begin{tabular}{|c|c|c|c|c|c|c|}
\hline \multirow[t]{2}{*}{ Age } & \multicolumn{4}{|c|}{ Harvest experience } & \multirow{2}{*}{ Total } & \multirow{2}{*}{ SE } \\
\hline & Harvested & Percent & Did not harvest & Percent & & \\
\hline \multicolumn{7}{|c|}{ (In owners) } \\
\hline Under 25 & W & W & 0 & 0 & W & 99.8 \\
\hline $25-34$ & 0 & 0 & 400 & 3 & 400 & 99.8 \\
\hline $35-44$ & 100 & 1 & 900 & 6 & 1,000 & 79.6 \\
\hline $45-54$ & 100 & 2 & 4,400 & 28 & 4,600 & 92.3 \\
\hline $55-64$ & 2,500 & 28 & 5,100 & 33 & 7,600 & 50.5 \\
\hline 65 or over & 6,100 & 68 & 1,500 & 10 & 7,600 & 68.5 \\
\hline No answer & 0 & 0 & W & W & W & 99.8 \\
\hline All other owners & 100 & 2 & 3,300 & 21 & 3,400 & 75.6 \\
\hline Total & 9,000 & 100 & 15,700 & 100 & 24,600 & 31.7 \\
\hline SE & 62.8 & & 36.8 & & 31.7 & \\
\hline \multicolumn{7}{|c|}{ (In thousands of acres) } \\
\hline Under 25 & 25 & 1 & 0 & 0 & 25 & 100 \\
\hline $25-34$ & 0 & 0 & 25 & 4 & 25 & 100 \\
\hline $35-44$ & 25 & 1 & 51 & 8 & 76 & 62.4 \\
\hline $45-54$ & 25 & 1 & 76 & 12 & 101 & 55.2 \\
\hline $55-64$ & 51 & 1 & 126 & 20 & 177 & 44.2 \\
\hline 65 or over & 329 & 9 & 101 & 16 & 430 & 33.3 \\
\hline No answer & 0 & 0 & 25 & 4 & 25 & 100 \\
\hline All other owners & 3,041 & 87 & 227 & 36 & 3,269 & 7.5 \\
\hline Total & 3,496 & 100 & 632 & 100 & 4,129 & 0.3 \\
\hline SE & 5.5 & & 30.3 & & 0.3 & \\
\hline
\end{tabular}


Table 137. Estimated number of ownership units and acres of forest land, by date of aquisition and form of ownership, New Mexico, 1993

\begin{tabular}{|c|c|c|c|c|c|c|c|}
\hline \multirow[b]{2}{*}{$\begin{array}{c}\text { Date of } \\
\text { acquisition }\end{array}$} & \multicolumn{5}{|c|}{ Ownership class } & \multirow[b]{2}{*}{ Total } & \multirow[b]{2}{*}{ SE } \\
\hline & $\begin{array}{l}\text { Forest } \\
\text { industry }\end{array}$ & Farmer & $\begin{array}{l}\text { Miscellaneous: } \\
\text { Individual }\end{array}$ & Corporation & Other & & \\
\hline \multicolumn{8}{|c|}{ (In owners) } \\
\hline 1990-1994 & 0 & 600 & 300 & W & 0 & 900 & 59.7 \\
\hline 1980-1989 & 0 & W & 5,600 & 0 & 2,600 & 8,300 & 60.9 \\
\hline $1970-1979$ & 0 & 800 & 8,800 & W & 600 & 10,300 & 55.6 \\
\hline 1960-1969 & 0 & 2,500 & 0 & 0 & 0 & 2,500 & 99.1 \\
\hline $1950-1959$ & 0 & 400 & 0 & W & 0 & 400 & 53.8 \\
\hline $1940-1949$ & 0 & 1,300 & 0 & 0 & 0 & 1,300 & 98.5 \\
\hline $1901-1939$ & 0 & 200 & 600 & W & W & 900 & 75.1 \\
\hline Prior to 1900 & W & W & 0 & 0 & W & W & 60.2 \\
\hline No answer & 0 & $W$ & 0 & 0 & 0 & $W$ & 64.3 \\
\hline Total & W & 6,000 & 15,300 & 100 & 3,300 & 24,600 & 31.7 \\
\hline SE & 80.3 & 49.1 & 46.2 & 58.3 & 79.8 & 31.7 & \\
\hline \multicolumn{8}{|c|}{ (In thousands of acres) } \\
\hline 1990-1994 & 0 & 126 & 25 & 230 & 0 & 382 & 62.1 \\
\hline 1980-1989 & 0 & 502 & 51 & 0 & 76 & 629 & 48.9 \\
\hline $1970-1979$ & 0 & 76 & 126 & 76 & 25 & 303 & 36.8 \\
\hline $1960-1969$ & 0 & 76 & 0 & 0 & 0 & 76 & 62.4 \\
\hline $1950-1959$ & 0 & 202 & 0 & 25 & 0 & 227 & 40.4 \\
\hline $1940-1949$ & 0 & 151 & 0 & 0 & 0 & 151 & 52.1 \\
\hline $1901-1939$ & 0 & 241 & 25 & 25 & 305 & 597 & 53.1 \\
\hline Prior to 1900 & 700 & 152 & 0 & 0 & 763 & 1,614 & 35.9 \\
\hline No answer & 0 & 121 & 0 & 0 & 28 & 149 & 60.2 \\
\hline Total & 700 & 1,648 & 227 & 356 & 1,197 & 4,129 & 0.3 \\
\hline SE & 85.6 & 27.1 & 40.4 & 65.9 & 41.9 & 0.3 & \\
\hline
\end{tabular}

W-fewer than 50 owners or less than 0.5 percent 
Table 138. Estimated number of ownership units and acres of forest land, by distance from tracts, New Mexico, 1993

Distance

Tracts

More than one tract

Total

1 tract Nearest tract

Farthest tract

(In owners)

Less than 1 mile

4,600

2,600

1,500

2-5 miles

1,000

2,800

2,700

6-15 miles

16-25 miles

0

26-50 miles

51-100 miles

More than 100 miles

No answer

2,900

0

W

100

W

W

5,200

600

700

700

W

W

No answer

W

Total 14,300 10,400

10,400

24,600

(In thousands of acres)

$\begin{array}{lrrr}\text { Less than } 1 \text { mile } & 312 & 2,016 & 51 \\ 2-5 \text { miles } & 76 & 126 & 51 \\ 6-15 \text { miles } & 0 & 58 & 261 \\ 16-25 \text { miles } & 0 & 25 & 131 \\ 26-50 \text { miles } & 51 & 76 & 656 \\ 51-100 \text { miles } & 76 & 51 & 721 \\ \text { More than 100 miles } & 177 & 76 & 558 \\ \text { No answer } & 213 & 796 & 796 \\ & & 3,224 & 3,224 \\ \text { Total } & 905 & \end{array}$

W-Fewer than 50 owners or less than 0.5 percent 
Table 139. Estimated number of ownership units and acres of forest land, by primary and secondary reason for owning forest land, New Mexico, 1993

\begin{tabular}{|c|c|c|c|c|}
\hline \multirow[t]{2}{*}{ Reason } & \multicolumn{2}{|c|}{ Primary reason } & \multicolumn{2}{|c|}{ Secondary reason } \\
\hline & Number & Percent & Number & Percent \\
\hline & \multicolumn{4}{|c|}{ (In owners) } \\
\hline Land investment & 5,200 & 21 & W & W \\
\hline Recreation & 400 & 2 & 300 & 1 \\
\hline Timber production & W & W & 600 & 3 \\
\hline Farm and domestic use & 2,100 & 9 & 4,600 & 19 \\
\hline Esthetic enjoyment & 6,600 & 27 & 100 & W \\
\hline Part of farm & 300 & 1 & 200 & 1 \\
\hline Part of residence & 5,600 & 23 & 6,500 & 27 \\
\hline Estate & 700 & 3 & 100 & w \\
\hline Other & 3,600 & 14 & 5,500 & 22 \\
\hline No secondary reason given & - & - & 6,600 & 27 \\
\hline No answer & 100 & $W$ & 100 & $W$ \\
\hline \multirow[t]{2}{*}{ Total } & 24,600 & 100 & 24,600 & 100 \\
\hline & \multicolumn{4}{|c|}{ (In thousands of acres) } \\
\hline Land investment & 177 & 4 & 76 & 2 \\
\hline Recreation & 1,137 & 28 & 185 & 5 \\
\hline Timber production & 355 & 9 & 838 & 20 \\
\hline Farm and domestic use & 1,037 & 25 & 283 & 7 \\
\hline Esthetic enjoyment & 152 & 4 & 51 & 1 \\
\hline Part of farm & 303 & 7 & 101 & 2 \\
\hline Part of residence & 126 & 3 & 126 & 3 \\
\hline Estate & 51 & 1 & 354 & 9 \\
\hline Other & 669 & 16 & 952 & 23 \\
\hline No secondary reason given & - & - & 1,041 & 25 \\
\hline No answer & 121 & 3 & 121 & 3 \\
\hline Total & 4,129 & 100 & 4,129 & 100 \\
\hline
\end{tabular}


Table 140. Estimated number of ownership units and acres of forest land, by primary benefit expected in the next 10 years and past harvest experience, New Mexico, 1993

\begin{tabular}{|c|c|c|c|c|c|c|}
\hline \multirow[t]{2}{*}{ Benefits expected } & \multicolumn{4}{|c|}{ Harvest Experience } & \multirow{2}{*}{ Total } & \multirow{2}{*}{ SE } \\
\hline & Harvested & Percent & Did not harvest & Percent & & \\
\hline \multicolumn{7}{|c|}{ (In owners) } \\
\hline Land value increase & 100 & 1 & 3,900 & 25 & 4,100 & 70.7 \\
\hline Recreation & 100 & 1 & 600 & 4 & 700 & 65 \\
\hline Income from timber & W & W & 0 & 0 & W & 38.6 \\
\hline Farm and domestic us $\epsilon$ & 300 & 4 & 2,500 & 16 & 2,800 & 53.9 \\
\hline Esthetic enjoyment & 5,100 & 57 & 5,300 & 34 & 10,400 & 63.2 \\
\hline Firewood & W & W & 0 & 0 & W & 99.8 \\
\hline Other & 3,300 & 37 & 3,200 & 20 & 6,600 & 55.4 \\
\hline No answer & 0 & 0 & 100 & 1 & 100 & 67.3 \\
\hline Total & 9,000 & 100 & 15,700 & 100 & 24,600 & 31.7 \\
\hline SE & 62.8 & & 36.8 & & 31.7 & \\
\hline \multicolumn{7}{|c|}{ (In thousands of acres) } \\
\hline Land value increase & 152 & 4 & $4 \quad 76$ & 12 & 227 & 40.4 \\
\hline Recreation & 1,137 & 33 & 76 & 12 & 1,213 & 40.2 \\
\hline Income from timber & 502 & 14 & 0 & 0 & 502 & 60.9 \\
\hline Farm and domestic us $\epsilon$ & 1,113 & 32 & 152 & 24 & 1,264 & 44.4 \\
\hline Esthetic enjoyment & 76 & 2 & 76 & 12 & 152 & 46.9 \\
\hline Firewood & 25 & 1 & 0 & 0 & 25 & 100 \\
\hline Other & 492 & 14 & 177 & 28 & 669 & 40.4 \\
\hline No answer & 0 & 0 & 76 & 12 & 76 & 62.4 \\
\hline Total & 3,496 & 100 & 632 & 100 & 4,129 & 0.3 \\
\hline SE & 5.5 & & 30.3 & & 0.3 & \\
\hline
\end{tabular}




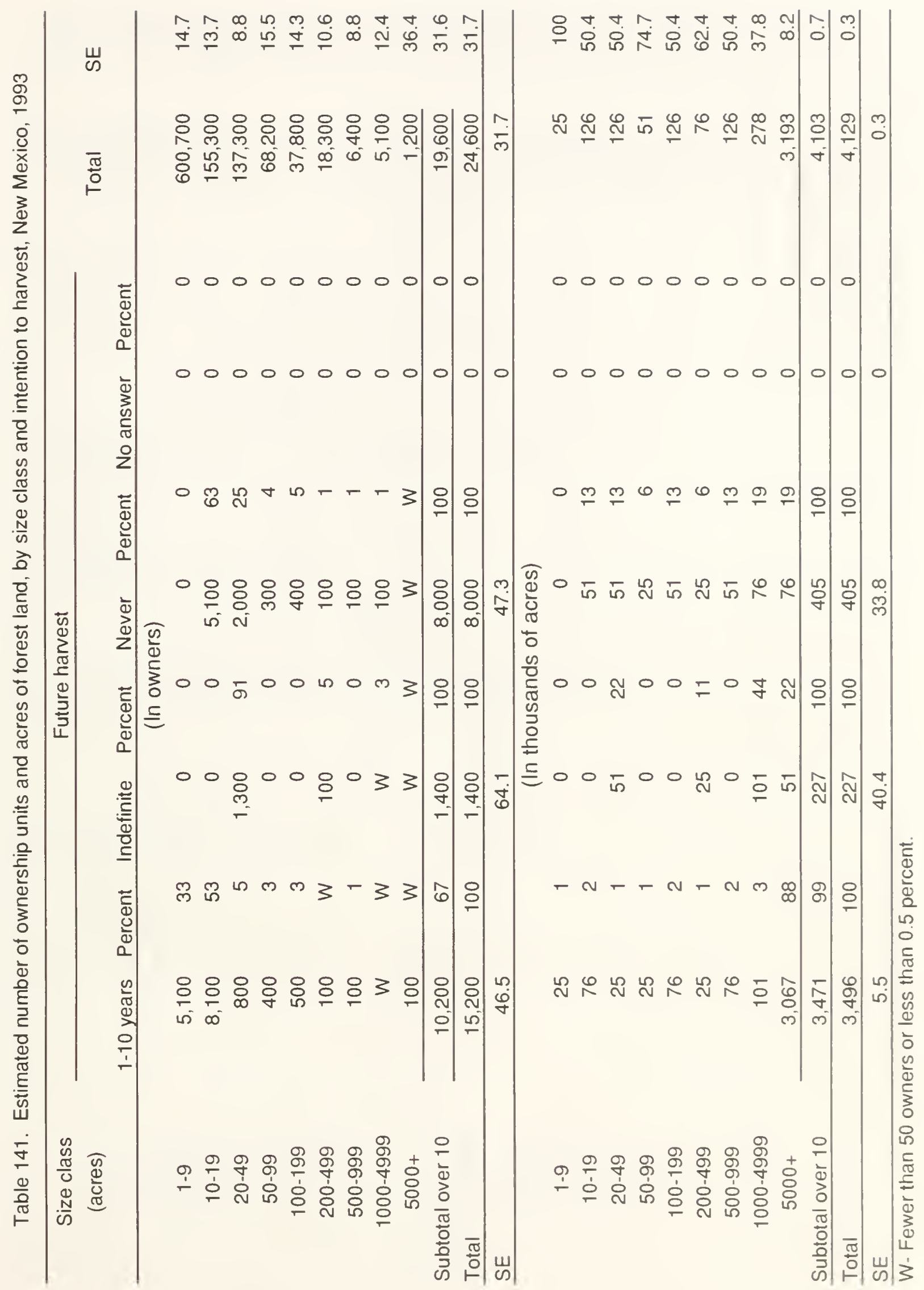




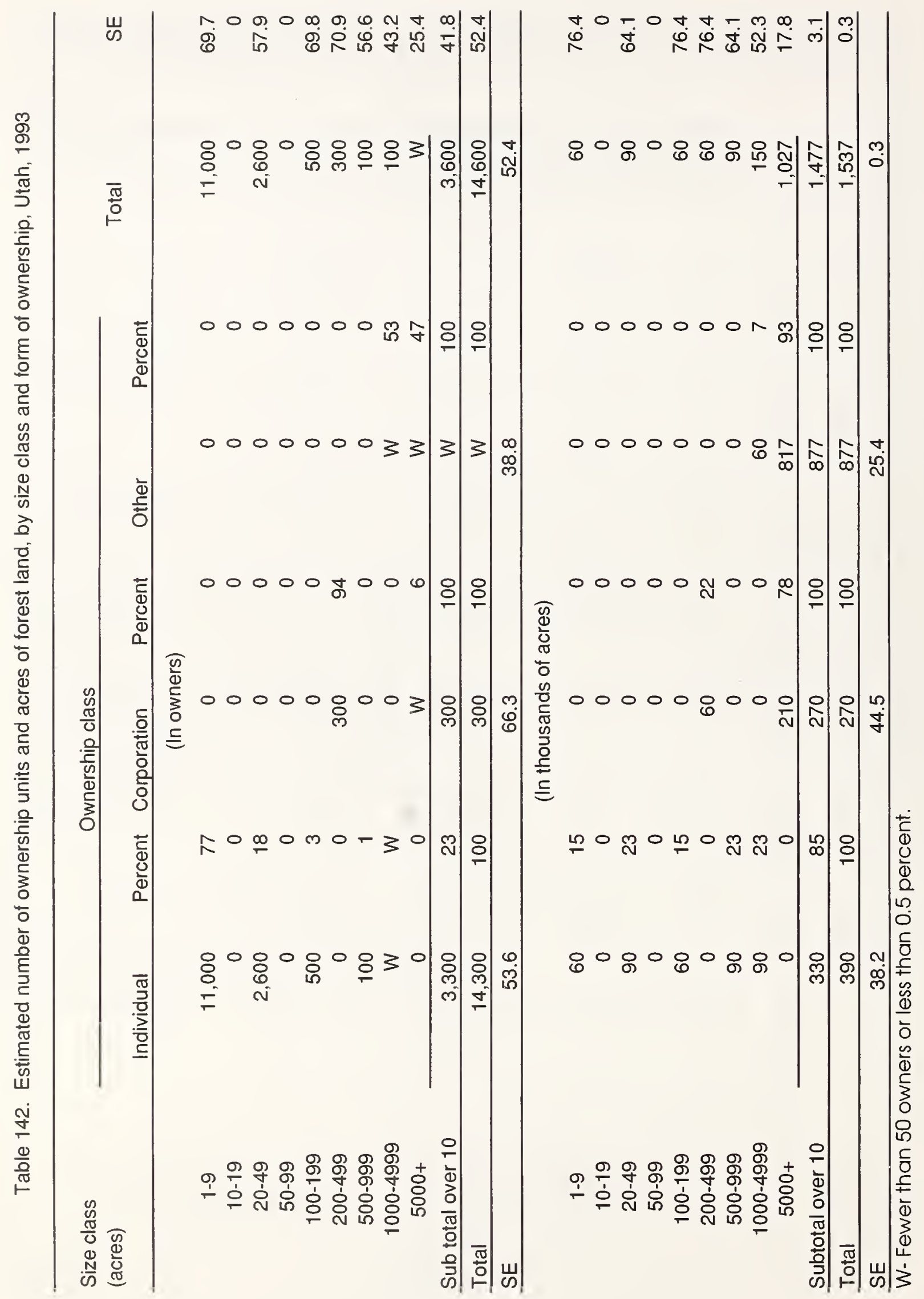


Table 143. Estimated number of ownership units and acres of forest land, by form of ownership and past harvest experience, Utah, 1993

Form of ownership

Harvest experience

Total SE Harvested Percent Did not harvest Percent (In owners)

\begin{tabular}{|c|c|c|c|c|c|c|}
\hline Individual + joint & 1,500 & 89 & 12,800 & 99 & 14,300 & 53.6 \\
\hline Partnership & W & 2 & W & W & W & 44.8 \\
\hline Corporation & 200 & 9 & 100 & 1 & 300 & 66.3 \\
\hline Other & $W$ & W & W & $W$ & W & 57.3 \\
\hline Total & 1,700 & 100 & 12,900 & 100 & 14,600 & 52.4 \\
\hline SE & 72.3 & & 59.1 & & 52.4 & \\
\hline \multicolumn{7}{|c|}{ (In thousands of acres) } \\
\hline Individual + joint & 120 & 12 & 270 & 53 & 390 & 38.2 \\
\hline Partnership & 180 & 17 & 30 & 6 & 210 & 46.3 \\
\hline Corporation & 90 & 9 & 180 & 35 & 270 & 44.5 \\
\hline Other & 637 & 62 & 30 & 6 & 667 & 41.7 \\
\hline Total & 1,027 & 100 & 510 & 100 & 1,537 & 0.3 \\
\hline SE & 17.8 & & 35.7 & & 0.3 & \\
\hline
\end{tabular}

W-Fewer than 50 owners or less than 0.5 percent 
Table 144. Estimated number of ownership units and acres of forest land, by incorporated and unincorporated businesses and past harvest experience, Utah, 1993

\begin{tabular}{|c|c|c|c|c|c|c|}
\hline \multirow[t]{2}{*}{ Nature of business } & \multicolumn{4}{|c|}{ Harvest } & \multirow{2}{*}{ Total } & \multirow{2}{*}{ SE } \\
\hline & Harvested & Percent & Did not harvest & Percent & & \\
\hline \multicolumn{7}{|c|}{ (In owners) } \\
\hline Incorporated: & & & & & & \\
\hline Farm & 200 & 9 & W & W & 200 & 92.7 \\
\hline Industrial business & 0 & 0 & W & W & W & 69.4 \\
\hline Sport/ recreation club & 0 & 0 & 100 & 1 & 100 & 99.8 \\
\hline Other & 0 & 0 & 0 & 0 & 0 & 0 \\
\hline Total corporate & 200 & 9 & 100 & 1 & 300 & 66.3 \\
\hline \multicolumn{7}{|l|}{ Unincorporated: } \\
\hline Forest industry & W & W & 0 & 0 & W & 56.5 \\
\hline Farm & 100 & 6 & 6,100 & 47 & 6,200 & 80.3 \\
\hline Misc. individual & 1,400 & 85 & 6,700 & 52 & 8,100 & 75.1 \\
\hline Other & 0 & 0 & 0 & 0 & 0 & 0 \\
\hline Total noncorporate & 1,500 & 91 & 12,800 & 99 & 14,300 & 53.4 \\
\hline Total & 1,700 & 100 & 12,900 & 100 & 14,600 & 52.4 \\
\hline SE & 72.3 & & 59.1 & & 52.4 & \\
\hline \multicolumn{7}{|c|}{ (In thousands of acres) } \\
\hline $\begin{array}{l}\text { Incorporated: } \\
\text { Farm }\end{array}$ & 90 & 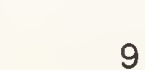 & 90 & 18 & 180 & 53.2 \\
\hline Industrial business & 0 & 0 & 60 & 12 & 60 & 76.4 \\
\hline Sport/ recreation club & 0 & 0 & 30 & 6 & 30 & 100 \\
\hline Other & 0 & 0 & 0 & 0 & 0 & 0 \\
\hline Total corporate & 90 & 9 & 180 & 35 & 270 & 44.5 \\
\hline \multicolumn{7}{|l|}{ Unincorporated: } \\
\hline Forest industry & 637 & 62 & 0 & 0 & 637 & 44.9 \\
\hline Farm & 240 & 23 & 270 & 53 & 510 & 35.7 \\
\hline Misc. individual & 60 & 6 & 60 & 12 & 120 & 57 \\
\hline Other & 0 & 0 & 0 & 0 & 0 & 0 \\
\hline Total noncorporate & 937 & 91 & 330 & 65 & 1,267 & 9.5 \\
\hline Total & 1,027 & 100 & 510 & 100 & 1,537 & 0.3 \\
\hline SE & 17.8 & & 35.7 & & 0.3 & \\
\hline
\end{tabular}

W- Fewer than 50 owners or less than 0.5 percent 


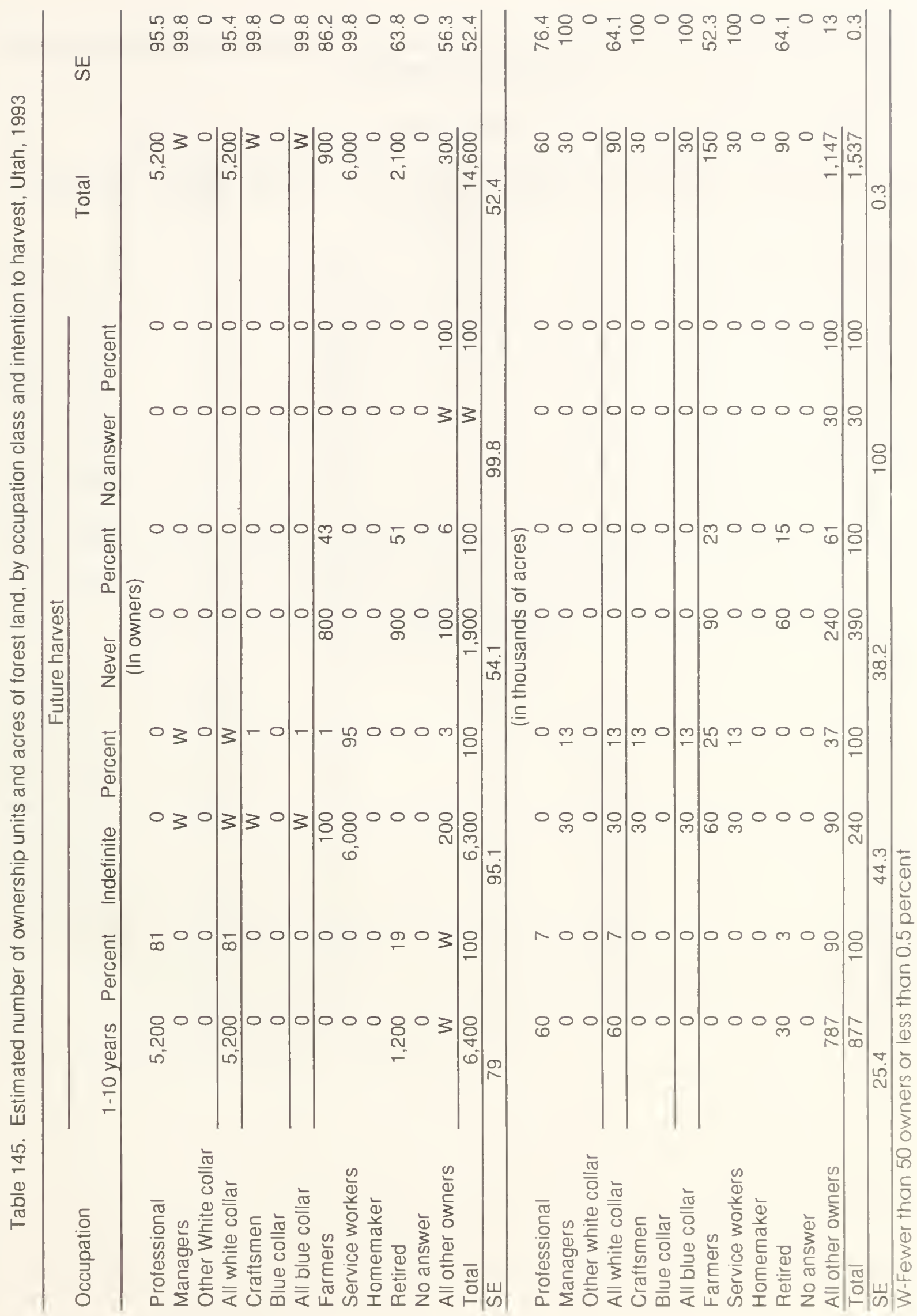


Table 146. Estimated number of ownership units and acres of forest land, by age class and past harvest experience, Utah, 1993

\begin{tabular}{|c|c|c|c|c|c|c|}
\hline \multirow[t]{2}{*}{ Age } & \multicolumn{4}{|c|}{ Harvest experience } & \multirow{2}{*}{ Total } & \multirow{2}{*}{ SE } \\
\hline & Harvested & Percent & Did not harvest & Percent & & \\
\hline \multicolumn{7}{|c|}{ (In owners) } \\
\hline Under 25 & 0 & 0 & 0 & 0 & 0 & 0 \\
\hline $25-34$ & 0 & 0 & 0 & 0 & 0 & 0 \\
\hline $35-44$ & 0 & 0 & 11,000 & 85 & 11,000 & 69.7 \\
\hline $45-54$ & 200 & 13 & 800 & 6 & 1,000 & 79.6 \\
\hline $55-64$ & W & 1 & 100 & 1 & 100 & 55.5 \\
\hline 65 or over & 1,300 & 75 & 900 & 7 & 2,200 & 61.8 \\
\hline No answer & 0 & 0 & 0 & 0 & 0 & 0 \\
\hline All other owners & 200 & 11 & 100 & 1 & 300 & 56.3 \\
\hline Total & 1,700 & 100 & 12,900 & 100 & 14,600 & 52.4 \\
\hline SE & 72.3 & & 59.1 & & 52.4 & \\
\hline \multicolumn{7}{|c|}{ (In thousands of acres) } \\
\hline Under 25 & 0 & 0 & 0 & 0 & 0 & 0 \\
\hline $25-34$ & 0 & 0 & 0 & 0 & 0 & 0 \\
\hline $35-44$ & 0 & 0 & 60 & 12 & 60 & 76.4 \\
\hline $45-54$ & 30 & 3 & 30 & 6 & 60 & 76.4 \\
\hline $55-64$ & 30 & 3 & 90 & 18 & 120 & 57 \\
\hline 65 or over & 60 & 6 & 90 & 18 & 150 & 52.3 \\
\hline No answer & 0 & 0 & 0 & 0 & 0 & 0 \\
\hline All other owners & 907 & 88 & 240 & 47 & 1,147 & 13 \\
\hline Total & 1,027 & 100 & 510 & 100 & 1,537 & 0.3 \\
\hline $\mathrm{SE}$ & 17.8 & & 35.5 & & 0.3 & \\
\hline
\end{tabular}

W-Fewer than 50 owners of less than 0.5 percent 
Table 147. Estimated number of ownership units and acres of forest land, by date of aquisition and form of ownership, Utah, 1993

Ownership class

\begin{tabular}{|c|c|c|c|c|c|c|c|}
\hline \multirow[b]{2}{*}{$\begin{array}{c}\text { Date of } \\
\text { acquisition }\end{array}$} & & \multirow[b]{2}{*}{ Total } & \multirow[b]{2}{*}{ SE } \\
\hline & $\begin{array}{l}\text { Forest } \\
\text { industry }\end{array}$ & Farmer & $\begin{array}{l}\text { Miscellaneous: } \\
\text { Individual }\end{array}$ & Corporation & Other & & \\
\hline & & & (In owners) & & & & \\
\hline 1990-1994 & 0 & 5,000 & 6,000 & 0 & 0 & 11,000 & 69.7 \\
\hline 1980-1989 & 0 & 0 & 200 & 0 & 0 & 200 & 99.8 \\
\hline 1970-1979 & 0 & 100 & 1,900 & 0 & 0 & 1,900 & 70.2 \\
\hline 1960-1969 & 0 & 100 & 0 & 100 & 0 & 200 & 63 \\
\hline 1950-1959 & 0 & 300 & 0 & W & 0 & 300 & 98 \\
\hline $1940-1949$ & 0 & W & 0 & 0 & 0 & W & 71.7 \\
\hline 1901-1939 & 0 & 100 & 0 & 0 & 0 & 100 & 73.2 \\
\hline Prior to 1900 & W & W & 0 & 0 & 0 & W & 56.1 \\
\hline No answer & 0 & 900 & 0 & 0 & 0 & 900 & 84 \\
\hline
\end{tabular}

\begin{tabular}{|c|c|c|c|c|c|c|c|}
\hline Total & $W$ & 6,400 & 8,100 & 100 & 0 & 14,600 & 52.4 \\
\hline SE & 56.5 & 78.2 & 75.1 & 95 & 0 & 52.4 & \\
\hline \multicolumn{8}{|c|}{ (In thousands of acres) } \\
\hline 1990-1994 & 0 & 30 & 30 & 0 & 0 & 60 & 76.4 \\
\hline 1980-1989 & 0 & 0 & 30 & 0 & 0 & 30 & 100 \\
\hline $1970-1979$ & 0 & 90 & 60 & 0 & 0 & 150 & 52.3 \\
\hline 1960-1969 & 0 & 120 & 0 & 30 & 0 & 150 & 52.3 \\
\hline $1950-1959$ & 0 & 30 & 0 & 60 & 0 & 90 & 64.1 \\
\hline $1940-1949$ & 0 & 60 & 0 & 0 & 0 & 60 & 76.4 \\
\hline 1901-1939 & 0 & 180 & 0 & 0 & 0 & 180 & 48.9 \\
\hline Prior to 1900 & 637 & 90 & 0 & 0 & 0 & 727 & 36.1 \\
\hline No answer & 0 & 90 & 0 & 0 & 0 & 90 & 64.1 \\
\hline Total & 637 & 690 & 120 & 90 & 0 & 1,537 & 0.3 \\
\hline SE & 44.9 & 33.5 & 57 & 64.1 & 0 & 0.3 & \\
\hline
\end{tabular}

W-fewer than 50 owners or less than 0.5 percent 
Table 148. Estimated number of ownership units and acres of forest land, by distance from tracts, Utah, 1993

\begin{tabular}{|c|c|c|c|c|}
\hline \multirow[t]{3}{*}{ Distance } & \multicolumn{3}{|c|}{ Tracts } & \multirow{3}{*}{ Total } \\
\hline & \multirow[b]{2}{*}{1 tract } & \multicolumn{2}{|c|}{ More than one tract } & \\
\hline & & Nearest tract & Farthest tract & \\
\hline \multicolumn{5}{|c|}{ (In owners) } \\
\hline Less than 1 mile & 0 & 300 & 300 & \\
\hline 2-5 miles & 0 & 100 & W & \\
\hline $6-15$ miles & 6,200 & W & 0 & \\
\hline 16-25 miles & 200 & W & 100 & \\
\hline 26-50 miles & W & W & W & \\
\hline $51-100$ miles & 200 & 700 & 700 & \\
\hline More than 100 miles & 6,000 & 100 & 200 & \\
\hline No answer & 800 & $W$ & $W$ & \\
\hline Total & 13,400 & 1,200 & 1,200 & 14,600 \\
\hline \multicolumn{5}{|c|}{ (In thousands of acres) } \\
\hline Less than 1 mile & 0 & 210 & 30 & \\
\hline $2-5$ miles & 0 & 60 & 30 & \\
\hline $6-15$ miles & 60 & 90 & 0 & \\
\hline $16-25$ miles & 60 & 30 & 180 & \\
\hline 26-50 miles & 30 & 490 & 60 & \\
\hline $51-100$ miles & 30 & 90 & 120 & \\
\hline More than 100 miles & 30 & 30 & 580 & \\
\hline No answer & 90 & 237 & 237 & \\
\hline Total & 300 & 1,237 & 1,237 & 1,537 \\
\hline
\end{tabular}

W-Fewer than 50 owners or less than 0.5 percent 
Table 149. Estimated number of ownership units and acres of forest land, by primary and secondary reason for owning forest land, Utah, 1993

\begin{tabular}{|c|c|c|c|c|}
\hline \multirow[t]{2}{*}{ Reason } & \multicolumn{2}{|c|}{ Primary reason } & \multicolumn{2}{|c|}{ Secondary reason } \\
\hline & Number & Percent & Number & Percent \\
\hline & \multicolumn{4}{|c|}{ (In owners) } \\
\hline Land investment & 100 & 1 & 0 & 0 \\
\hline Recreation & 7,800 & 53 & 700 & 5 \\
\hline Timber production & 0 & 0 & 5,000 & 34 \\
\hline Farm and domestic use & W & W & 7,500 & 51 \\
\hline Esthetic enjoyment & 5,700 & 39 & 0 & 0 \\
\hline Part of farm & 1,000 & 7 & W & W \\
\hline Part of residence & 0 & 0 & 0 & 0 \\
\hline Estate & W & W & 300 & 2 \\
\hline Other & w & W & W & W \\
\hline No secondary reason given & - & - & 1,000 & 7 \\
\hline No answer & W & W & W & $W$ \\
\hline \multirow[t]{2}{*}{ Total } & 14,600 & 100 & 14,600 & 100 \\
\hline & \multicolumn{4}{|c|}{ (In thousands of acres) } \\
\hline Land investment & 60 & 4 & 60 & 4 \\
\hline Recreation & 150 & 10 & 90 & 6 \\
\hline Timber production & 0 & 0 & 60 & 4 \\
\hline Farm and domestic use & 297 & 19 & 150 & 10 \\
\hline Esthetic enjoyment & 60 & 4 & 0 & 0 \\
\hline Part of farm & 360 & 23 & 60 & 4 \\
\hline Part of residence & 0 & 0 & 0 & 0 \\
\hline Estate & 30 & 2 & 60 & 4 \\
\hline Other & 180 & 12 & 297 & 19 \\
\hline No secondary reason given & - & - & 360 & 23 \\
\hline No answer & 400 & 26 & 400 & 26 \\
\hline Total & 1,537 & 100 & 1,537 & 100 \\
\hline
\end{tabular}


Table 150. Estimated number of ownership units and acres of forest land, by primary benefit expected in the next 10 years and past harvest experience, Utah, 1993

\begin{tabular}{|c|c|c|c|c|c|c|}
\hline \multirow[t]{2}{*}{ Benefits expected } & \multicolumn{4}{|c|}{ Harvest Experience } & \multirow{2}{*}{ Total } & \multirow{2}{*}{ SE } \\
\hline & Harvested & Percent & Did not harvest & Percent & & \\
\hline \multicolumn{7}{|c|}{ (In owners) } \\
\hline Land value increase & W & 1 & W & W & W & 69.7 \\
\hline Recreation & 1,500 & 87 & 6,100 & 47 & 7,600 & 80.2 \\
\hline Income from timber & 200 & 9 & 0 & 0 & 200 & 99.8 \\
\hline Farm and domestic us $€$ & 100 & 3 & 300 & 3 & 400 & 71 \\
\hline Esthetic enjoyment & 0 & 0 & 5.700 & 44 & 5,700 & 88.5 \\
\hline Firewood & 0 & 0 & 0 & 0 & 0 & 0 \\
\hline Other & W & W & 100 & W & 100 & 79.1 \\
\hline No answer & W & W & 800 & 6 & 800 & 98.8 \\
\hline Total & 1,700 & 100 & 12,900 & 100 & 14,600 & 52.4 \\
\hline SE & 72.3 & & 59.1 & & 52.4 & \\
\hline \multicolumn{7}{|c|}{ (In thousands of acres) } \\
\hline Land value increase & 30 & 3 & 30 & 6 & 60 & 76.4 \\
\hline Recreation & 150 & 15 & 120 & 23 & 270 & 42.6 \\
\hline Income from timber & 30 & 3 & 0 & 0 & 30 & 100 \\
\hline Farm and domestic us $\epsilon$ & 297 & 29 & 150 & 29 & 447 & 49.2 \\
\hline Esthetic enjoyment & 0 & 0 & 60 & 12 & 60 & 76.4 \\
\hline Firewood & 0 & 0 & 0 & 0 & 0 & 0 \\
\hline Other & 90 & 9 & 90 & 18 & 180 & 53.2 \\
\hline No answer & 430 & 42 & 60 & 12 & 490 & 60.1 \\
\hline Total & 1,027 & 100 & 510 & 100 & 1,537 & 0.3 \\
\hline SE & 17.8 & 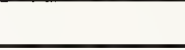 & 35.7 & & 0.3 & \\
\hline
\end{tabular}




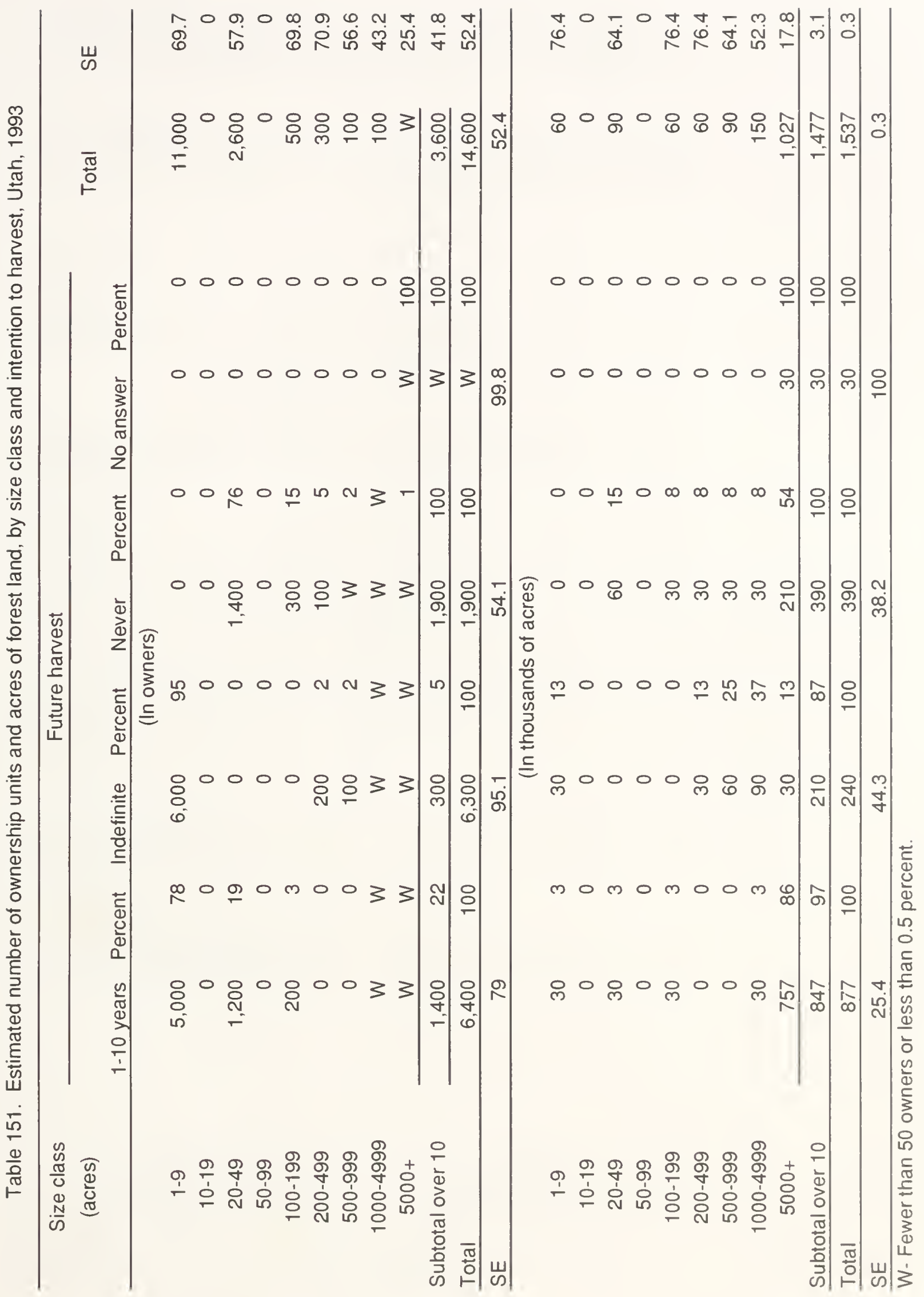




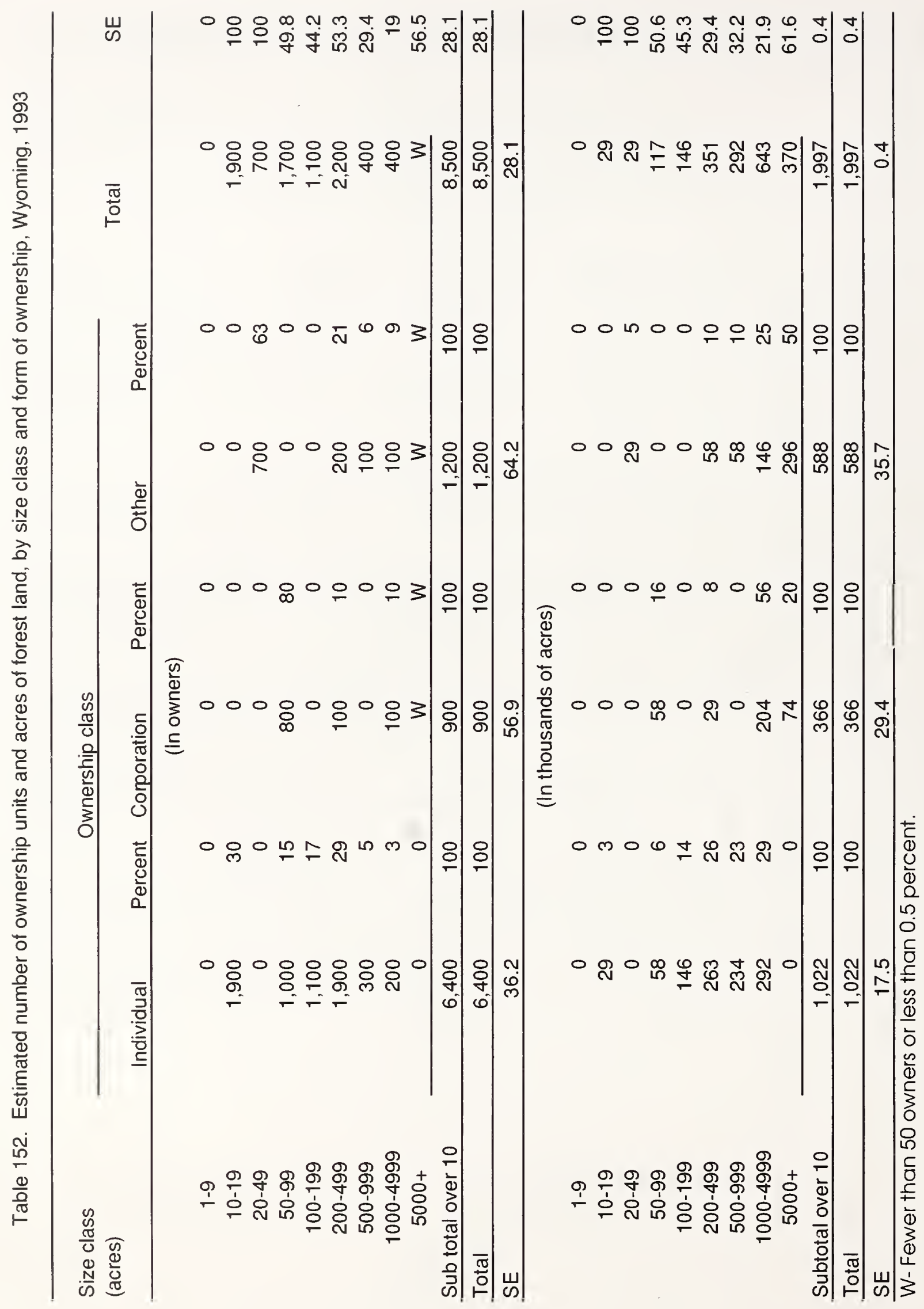


Table 153. Estimated number of ownership units and acres of forest land, by form of ownership and past harvest experience, Wyoming, 1993

Form of ownership

Harvest experience

Total

Harvested Percent Did notharvest Percent

(In owners)

\begin{tabular}{|c|c|c|c|c|c|c|}
\hline Individual + joint & 2,200 & 79 & 4,200 & 73 & 6,400 & 36.2 \\
\hline Partnership & 100 & 3 & 1,000 & 17 & 1,100 & 69.8 \\
\hline Corporation & 400 & 15 & 500 & 9 & 900 & 56.9 \\
\hline Other & 100 & 3 & 0 & 0 & 100 & 98.2 \\
\hline Total & 2,800 & 100 & 5,700 & 100 & 8,500 & 28.1 \\
\hline SE & 23.8 & & 42.7 & & 28.1 & \\
\hline \multicolumn{7}{|c|}{ (In thousands of acres) } \\
\hline Individual + joint & 730 & 55 & 292 & 45 & 1,022 & 17.5 \\
\hline Partnership & 88 & 7 & 204 & 32 & 292 & 32.2 \\
\hline Corporation & 220 & 17 & 146 & 23 & 366 & 29.4 \\
\hline Other & 296 & 22 & 0 & 0 & 296 & 78.6 \\
\hline Total & 1,334 & 100 & 643 & 100 & 1,977 & 0.4 \\
\hline SE & 10.6 & & 21.9 & & 0.4 & \\
\hline
\end{tabular}

W-Fewer than 50 owners or less than 0.5 percent 
Table 154. Estimated number of ownership units and acres of forest land, by incorporated and unincorporated businesses and past harvest experience, Wyoming, 1993

\begin{tabular}{|c|c|c|c|c|c|c|}
\hline \multirow[t]{2}{*}{ Nature of business } & \multicolumn{4}{|c|}{ Hanvest } & \multirow{2}{*}{ Total } & \multirow{2}{*}{ SE } \\
\hline & Harvested & Percent & Did not harvest & Percent & & \\
\hline \multicolumn{7}{|c|}{ (In owners) } \\
\hline \multicolumn{7}{|l|}{ Incorporated: } \\
\hline Forest industry & W & W & 0 & 0 & W & 100 \\
\hline Farm & 400 & 15 & 100 & 2 & 500 & 68.5 \\
\hline Real estate & 0 & 0 & 400 & 7 & 400 & 100 \\
\hline Other & 0 & 0 & 0 & 0 & 0 & 0 \\
\hline Total corporate & 400 & 15 & 500 & 9 & 900 & 56.9 \\
\hline \multicolumn{7}{|l|}{ Unincorporated: } \\
\hline Farm & 1,700 & 59 & 2,500 & 44 & 4,200 & 47 \\
\hline Misc. individual & 800 & 26 & 1,900 & 33 & 2,700 & 51.3 \\
\hline Sport/ recreation club & 0 & 0 & 700 & 13 & 700 & 100 \\
\hline Other & $W$ & W & 0 & 0 & W & 71.6 \\
\hline Total noncorporate & 2,400 & 85 & 5,100 & 91 & 7,600 & 31.5 \\
\hline Total & 2,800 & 100 & 5,700 & 100 & 8,500 & 28.1 \\
\hline SE & 23.8 & & 42.7 & & 28.1 & \\
\hline \multicolumn{7}{|c|}{ (In thousands of acres) } \\
\hline Incorporated: & & & & & & \\
\hline Forest industry & 45 & 3 & 0 & 0 & 45 & 100 \\
\hline Farm & 175 & 13 & 117 & 18 & 292 & 32.2 \\
\hline Real estate & 0 & 0 & 29 & 5 & 29 & 100 \\
\hline Other & 0 & 0 & 0 & 0 & 0 & 0 \\
\hline Total corporate & 220 & 17 & 146 & 23 & 366 & 29.4 \\
\hline \multicolumn{7}{|l|}{ Unincorporated: } \\
\hline Farm & 759 & 57 & 351 & 55 & 1,110 & 16.9 \\
\hline Misc. individual & 88 & 7 & 117 & 18 & 204 & 38.3 \\
\hline Sport/ recreation club & 0 & 0 & 29 & 5 & 29 & 100 \\
\hline Other & 267 & 20 & 0 & 0 & 267 & 88 \\
\hline Total noncorporate & 1,114 & 83 & 497 & 77 & 1,611 & 6.7 \\
\hline Total & 1,334 & 100 & 643 & 100 & 1,977 & 0.4 \\
\hline $\mathrm{SE}$ & 10.6 & & 21.9 & & 0.4 & \\
\hline
\end{tabular}

$\mathrm{W}$ - Fewer than 50 owners or less than 0.5 percent 


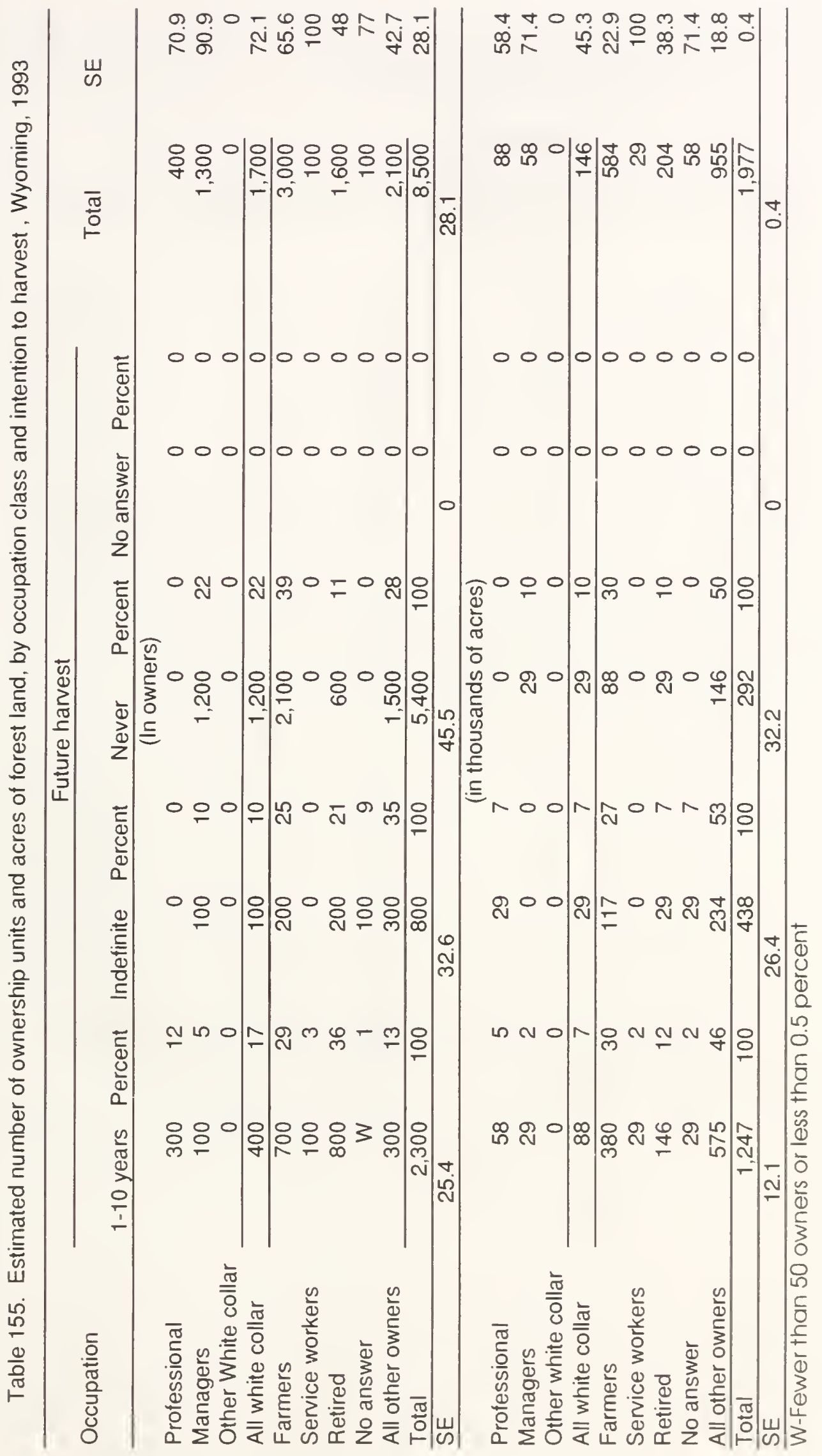


Table 156. Estimated number of ownership units and acres of forest land, by age class and past harvest experience, Wyoming, 1993

\begin{tabular}{|c|c|c|c|c|c|c|}
\hline \multirow[t]{2}{*}{ Age } & \multicolumn{4}{|c|}{ Harvest experience } & \multirow{2}{*}{ Total } & \multirow{2}{*}{ SE } \\
\hline & Harvested & Percent & Did not harvest & Percent & & \\
\hline \multicolumn{7}{|c|}{ (In owners) } \\
\hline Under 25 & 0 & 0 & 0 & 0 & 0 & 0 \\
\hline $25-34$ & 100 & 3 & 0 & 0 & 100 & 71 \\
\hline $35-44$ & 100 & 2 & W & W & 100 & 60.2 \\
\hline $45-54$ & 600 & 19 & 200 & 3 & 700 & 41.8 \\
\hline $55-64$ & 600 & 23 & 3,400 & 60 & 4,000 & 56 \\
\hline 65 or over & 800 & 30 & 600 & 10 & 1,400 & 52.4 \\
\hline No answer & 100 & 2 & 0 & 0 & 100 & 70.2 \\
\hline All other owners & 600 & 21 & 1,500 & 26 & 2,100 & 42.7 \\
\hline Tota! & 2,800 & 100 & 5,700 & 100 & 8,500 & 28.1 \\
\hline SE & 23.8 & & 42.7 & & 28.1 & \\
\hline \multicolumn{7}{|c|}{ (In thousands of acres) } \\
\hline Under 25 & 0 & 0 & 0 & 0 & 0 & 0 \\
\hline $25-34$ & 58 & 4 & 0 & 0 & 58 & 71.4 \\
\hline $35-44$ & 58 & 4 & 29 & 5 & 88 & 58.4 \\
\hline $45-54$ & 175 & 13 & 58 & 9 & 234 & 35.9 \\
\hline $55-64$ & 204 & 15 & 175 & 27 & 380 & 28.3 \\
\hline 65 or over & 175 & 13 & 29 & 5 & 204 & 38.3 \\
\hline No answer & 58 & 4 & 0 & 0 & 58 & 71.4 \\
\hline All other owners & 604 & 45 & 351 & 55 & 955 & 18.8 \\
\hline Total & 1,334 & 100 & 643 & 100 & 1,977 & 0.4 \\
\hline SE & 10.6 & & 21.9 & & 0.4 & \\
\hline
\end{tabular}

W-Fewer than 50 owners of less than 0.5 percent 
Table 157. Estimated number of ownership units and acres of forest land, by date of aquisition and form of ownership, Wyoming, 1993

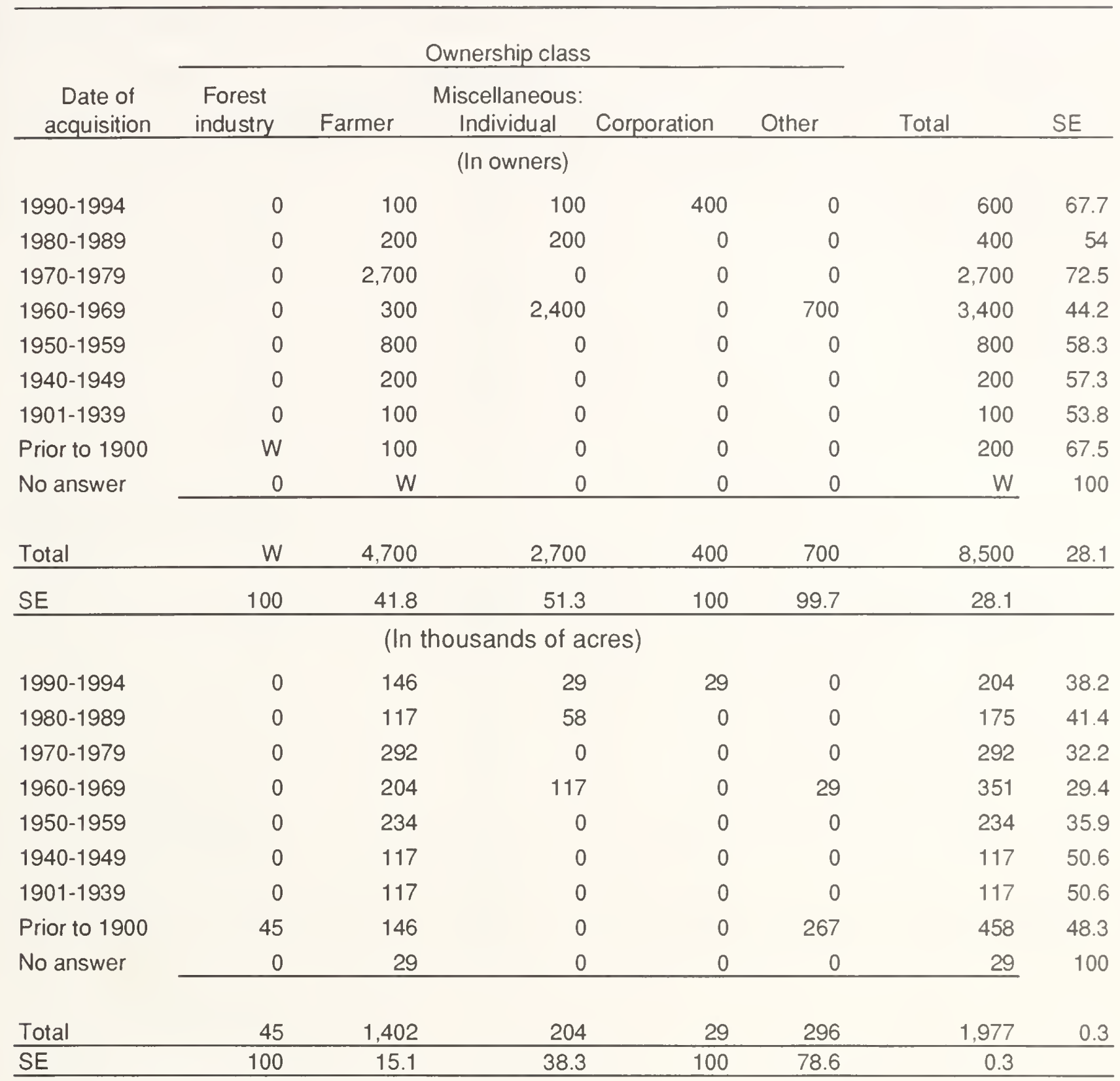

W-fewer than 50 owners or less than 0.5 percent 
Table 158. Estimated number of ownership units and acres of forest land, by distance from tracts, Wyoming, 1993

\begin{tabular}{|c|c|c|c|c|}
\hline \multirow{3}{*}{ Distance } & \multicolumn{3}{|c|}{ Tracts } & \multirow{3}{*}{ Total } \\
\hline & \multirow[b]{2}{*}{1 tract } & \multicolumn{2}{|c|}{ More than one tract } & \\
\hline & & Nearest tract & Farthest tract & \\
\hline \multicolumn{5}{|c|}{ (In owners) } \\
\hline Less than 1 mile & 3,500 & 2,200 & 100 & \\
\hline $2-5$ miles & 0 & W & 600 & \\
\hline $6-15$ miles & W & 500 & 200 & \\
\hline $16-25$ miles & 100 & 100 & 100 & \\
\hline $26-50$ miles & 700 & 300 & 200 & \\
\hline $51-100$ miles & 0 & 600 & 600 & \\
\hline More than 100 miles & W & 400 & 2,200 & \\
\hline No answer & 0 & 0 & W & \\
\hline Total & 4,400 & 4,100 & 4,100 & 8,500 \\
\hline \multicolumn{5}{|c|}{ (In thousands of acres) } \\
\hline Less than 1 mile & 468 & 658 & 58 & \\
\hline $2-5$ miles & 0 & 58 & 234 & \\
\hline $6-15$ miles & 325 & 204 & 321 & \\
\hline $16-25$ miles & 29 & 58 & 88 & \\
\hline $26-50$ miles & 58 & 29 & 162 & \\
\hline $51-100$ miles & 0 & 29 & 29 & \\
\hline More than 100 miles & 29 & 29 & 146 & \\
\hline No answer & 0 & 0 & 29 & \\
\hline Total & 910 & 1,067 & 1,067 & 1,977 \\
\hline
\end{tabular}


Table 159. Estimated number of ownership units and acres of forest land, by primary and secondary reason for owning forest land, Wyoming, 1993

\begin{tabular}{|c|c|c|c|c|}
\hline \multirow[t]{2}{*}{ Reason } & \multicolumn{2}{|c|}{ Primary reason } & \multicolumn{2}{|c|}{ Secondary reason } \\
\hline & Number & Percent & Number & Percent \\
\hline & \multicolumn{4}{|c|}{ (In owners) } \\
\hline Land investment & 500 & 6 & $W$ & W \\
\hline Recreation & 1,000 & 12 & 900 & 11 \\
\hline Timber production & 0 & 0 & 200 & 2 \\
\hline Farm and domestic use & 900 & 11 & 100 & 1 \\
\hline Esthetic enjoyment & 1,900 & 22 & 400 & 5 \\
\hline Part of farm & 2,800 & 32 & 500 & 6 \\
\hline Part of residence & 900 & 11 & 1,300 & 15 \\
\hline Estate & W & W & 800 & 9 \\
\hline Other & 200 & 2 & 0 & 0 \\
\hline No secondary reason given & - & - & 3,900 & 46 \\
\hline No answer & 400 & 5 & 400 & 5 \\
\hline \multirow[t]{2}{*}{ Total } & 8,500 & 100 & 8,500 & 100 \\
\hline & \multicolumn{4}{|c|}{ (In thousands of acres) } \\
\hline Land investment & 58 & 3 & 74 & 4 \\
\hline Recreation & 146 & 7 & 263 & 13 \\
\hline Timber production & 45 & 2 & 146 & 7 \\
\hline Farm and domestic use & 409 & 21 & 117 & 6 \\
\hline Esthetic enjoyment & 88 & 4 & 117 & 6 \\
\hline Part of farm & 467 & 24 & 204 & 10 \\
\hline Part of residence & 263 & 13 & 175 & 9 \\
\hline Estate & 29 & 2 & 204 & 10 \\
\hline Other & 384 & 19 & 0 & 0 \\
\hline No secondary reason given & - & - & 588 & 30 \\
\hline No answer & 88 & 5 & 88 & 5 \\
\hline Total & 1,977 & 100 & 1.977 & 100 \\
\hline
\end{tabular}

W-fewer than 50 owners or less than 0.5 percent 
Table 160. Estimated number of ownership units and acres of forest land, by primary benefit expected in the next 10 years and past harvest experience, Wyoming, 1993

\begin{tabular}{|c|c|c|c|c|c|c|}
\hline \multirow[t]{2}{*}{ Benefits expected } & \multicolumn{4}{|c|}{ Harvest Experience } & \multirow{2}{*}{ Total } & \multirow{2}{*}{ SE } \\
\hline & Harvested & Percent & Did not harvest & Percent & & \\
\hline \multicolumn{7}{|c|}{ (In owners) } \\
\hline Land value increase & W & 1 & 600 & 11 & 600 & 92.3 \\
\hline Recreation & 300 & 10 & 1.000 & 17 & 1,300 & 61.1 \\
\hline Income from timber & 200 & 6 & 0 & 0 & 200 & 61.9 \\
\hline Farm and domestic us $€$ & 700 & 25 & 200 & 4 & 900 & 32.6 \\
\hline Esthetic enjoyment & 800 & 27 & 3,400 & 59 & 4,100 & 55.2 \\
\hline Firewood & 100 & 4 & 100 & 2 & 200 & 60.9 \\
\hline Other & 100 & 4 & 400 & 7 & 500 & 79 \\
\hline No answer & 700 & 24 & 0 & 0 & 700 & 68 \\
\hline Total & 2,800 & 100 & 5,700 & 100 & 8,500 & 28.1 \\
\hline SE & 23.8 & & 42.7 & & 28.1 & \\
\hline \multicolumn{7}{|c|}{ (In thousands of acres) } \\
\hline Land value increase & 29 & 2 & 88 & 14 & 117 & 50.6 \\
\hline Recreation & 88 & 7 & 146 & 23 & 234 & 35.9 \\
\hline Income from timber & 191 & 14 & 0 & 0 & 191 & 41.6 \\
\hline Farm and domestic us $\epsilon$ & 647 & 48 & 175 & 27 & 822 & 23.2 \\
\hline Esthetic enjoyment & 146 & 11 & 175 & 27 & 321 & 30.7 \\
\hline Firewood & 58 & 4 & 29 & 5 & 88 & 58.4 \\
\hline Other & 88 & 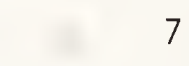 & 29 & 5 & 117 & 50.6 \\
\hline No answer & 88 & 7 & 0 & 0 & 88 & 58.4 \\
\hline Total & 1,334 & 100 & 643 & 100 & 1,977 & 0.4 \\
\hline SE & 10.6 & & 21.9 & & 0.4 & \\
\hline
\end{tabular}




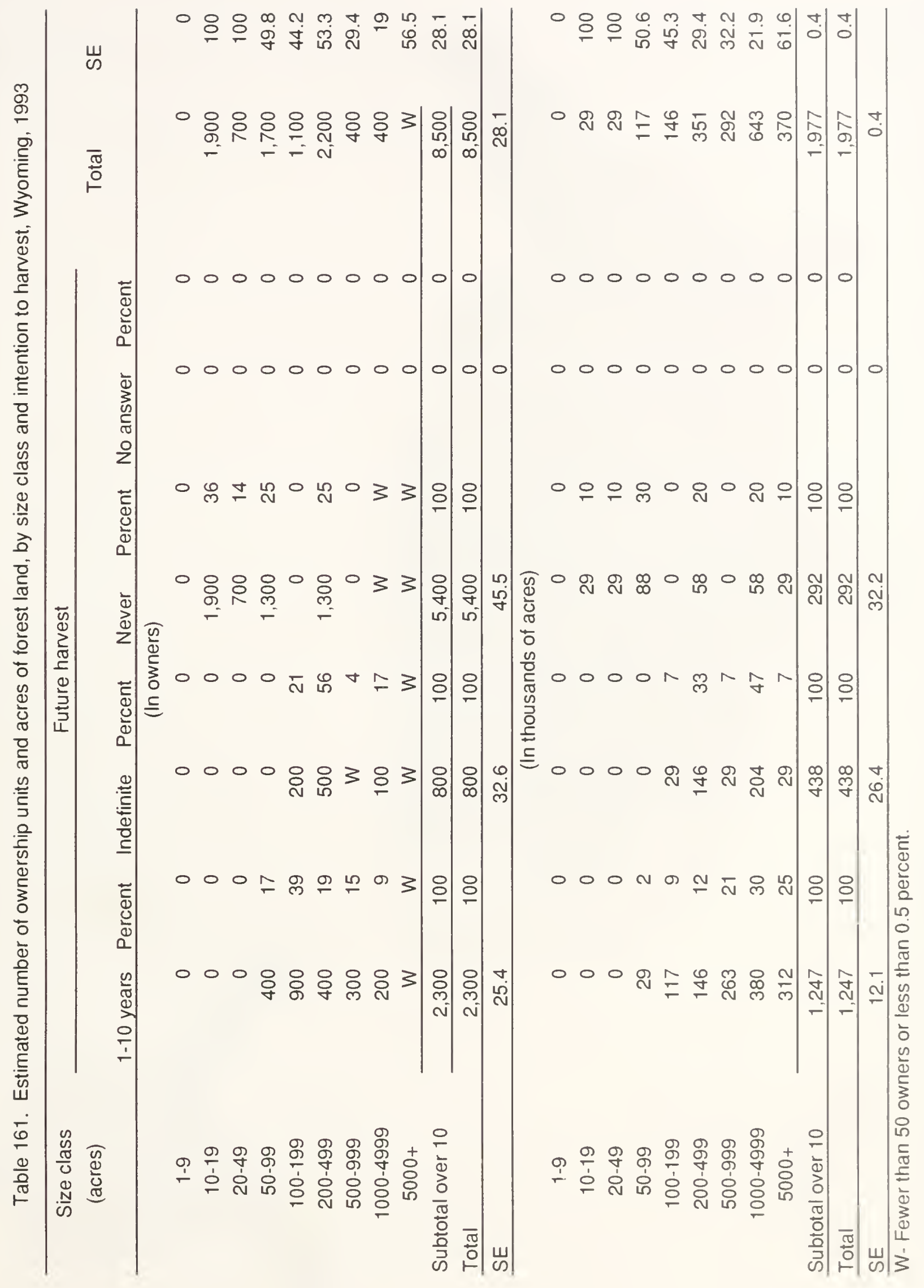




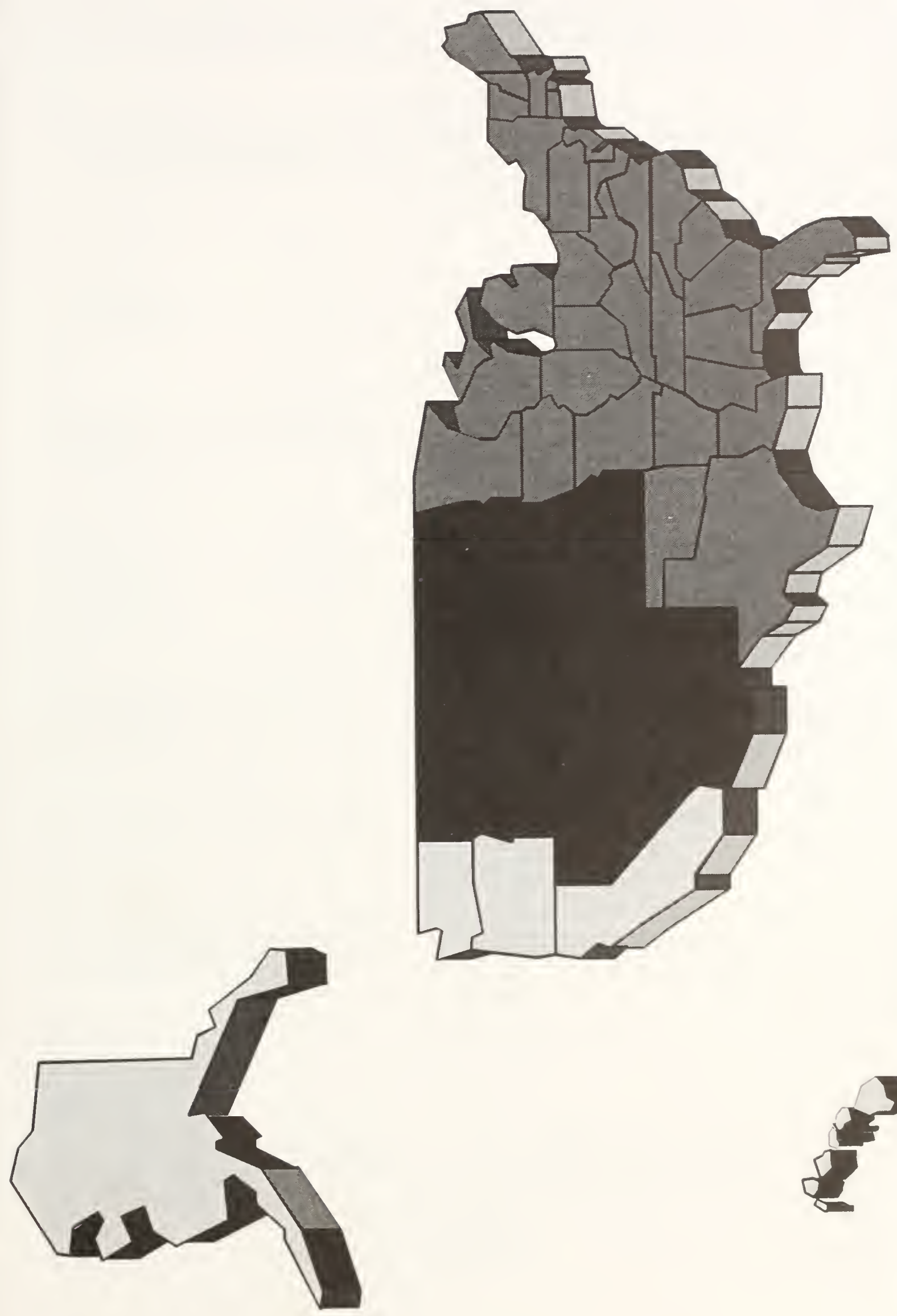

1 $\frac{1}{10}$ 0 II $\frac{1}{6}$ $\frac{1}{6}$ $\frac{0}{4}$

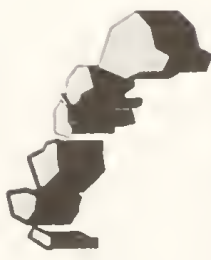




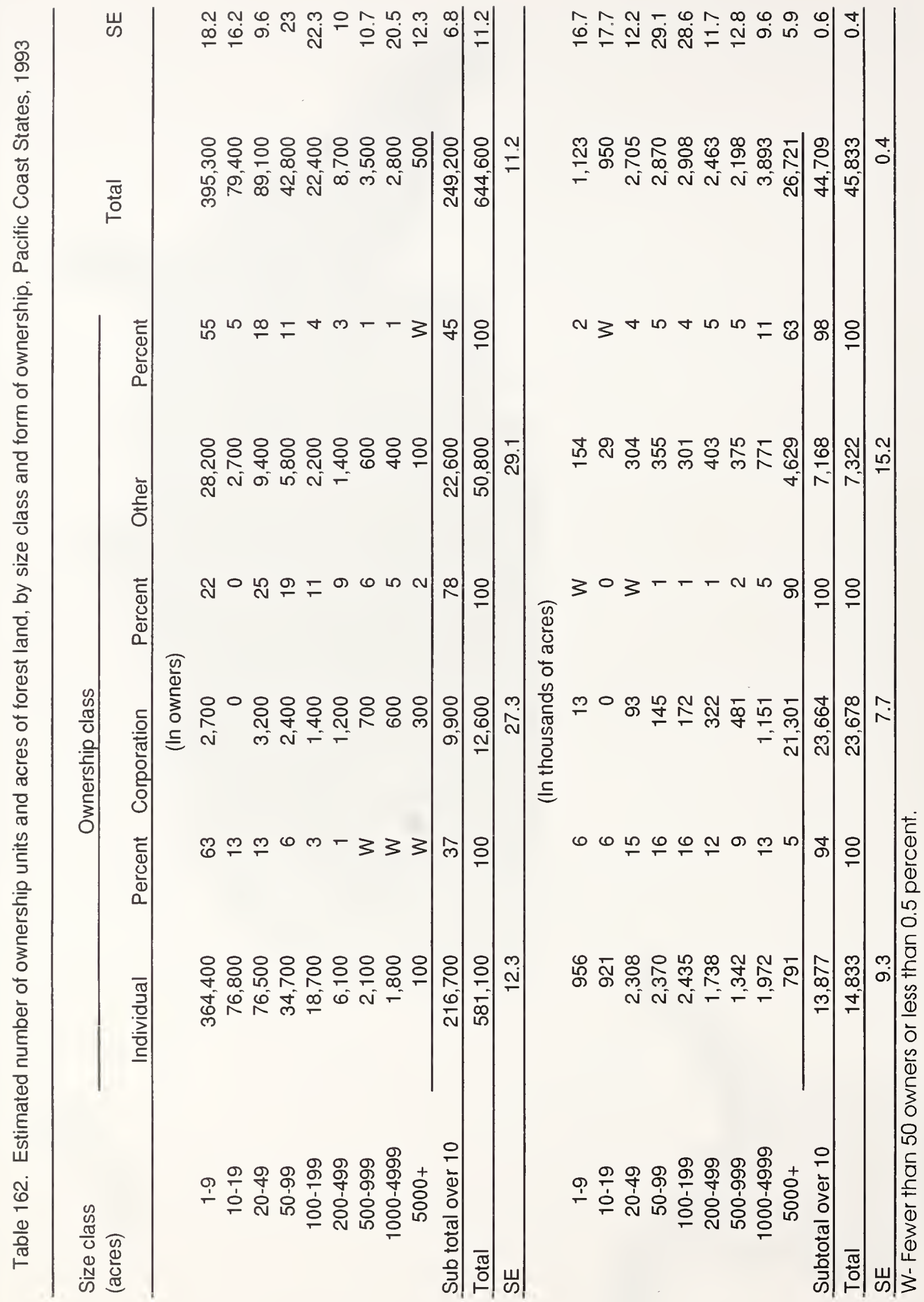


Table 163. Estimated number of ownership units and acres of forest land, by form of ownership and past harvest experience, Pacific Coast States, 1993

\begin{tabular}{|c|c|c|c|c|c|c|}
\hline \multirow[t]{2}{*}{ Form of ownership } & \multicolumn{4}{|c|}{ Harvest experience } & \multirow{2}{*}{ Total } & \multirow{2}{*}{ SE } \\
\hline & Harvested & Percent & Did not harvest & Percent & & \\
\hline \multicolumn{7}{|c|}{ (In owners) } \\
\hline Individual + joint & 270,400 & 90 & 310,700 & 90 & 581,100 & 12.3 \\
\hline Partnership & 12.000 & 4 & 11,200 & 3 & 23,200 & 26.2 \\
\hline Corporation & 3.700 & 1 & 9,000 & 3 & 12,600 & 27.3 \\
\hline Club/association & 800 & W & 10,500 & 3 & 11,300 & 86.4 \\
\hline Other & 12,600 & 4 & 3,700 & 1 & 16,300 & 57.4 \\
\hline Total & 299,300 & 100 & 345,200 & 100 & 644,600 & 11.2 \\
\hline SE & 15.4 & & 16.8 & & 11.2 & \\
\hline \multicolumn{7}{|c|}{ (In thousands of acres) } \\
\hline Individual + joint & 10,383 & 26 & 4,450 & 67 & 14,833 & 9.3 \\
\hline Partnership & 3.193 & 8 & 704 & 11 & 3,897 & 16.1 \\
\hline Corporation & 22,443 & 57 & 1,235 & 19 & 23,678 & 7.7 \\
\hline Club/association & 113 & W & 58 & 1 & 171 & 39.5 \\
\hline Other & 3,055 & 8 & 199 & 3 & 3,253 & 30.7 \\
\hline Total & 39,186 & 100 & 6,647 & 100 & 45,833 & 0.4 \\
\hline SE & 1.4 & & 8 & & 0.4 & \\
\hline
\end{tabular}

W-Fewer than 50 owners or less than 0.5 percent 
Table 164. Estimated number of ownership units and acres of forest land, by incorporated and unincorporated businesses and past harvest experience, Pacific Coast States, 1993

\begin{tabular}{|c|c|c|c|c|c|c|}
\hline \multirow[t]{2}{*}{ Nature of business } & \multicolumn{4}{|c|}{ Hanvest } & \multirow{2}{*}{ Total } & \multirow{2}{*}{ SE } \\
\hline & Harvested & Percent & Did not harvest & Percent & & \\
\hline \multicolumn{7}{|c|}{ (In owners) } \\
\hline \multicolumn{7}{|l|}{ Incorporated: } \\
\hline Forest industry & 900 & W & 0 & 0 & 900 & 40.4 \\
\hline Farm & 1,100 & W & 4,300 & 1 & 5,400 & 31.2 \\
\hline Industrial business & 100 & W & 600 & W & 600 & 58 \\
\hline Real estate & 200 & W & 4,100 & 1 & 4,300 & 68.2 \\
\hline Non-industrial & W & W & 0 & 0 & W & 95.7 \\
\hline Sport/ recreation club & 500 & W & 0 & 0 & 500 & 91.5 \\
\hline Public utility & W & W & 0 & 0 & W & 79.2 \\
\hline Other & 800 & W & W & W & 900 & 41.8 \\
\hline Total corporate & 3,700 & 1 & 9,000 & 3 & 12,600 & 27.3 \\
\hline \multicolumn{7}{|l|}{ Unincorporated: } \\
\hline Forest industry & 100 & W & 0 & 0 & 100 & 36.7 \\
\hline Farm & 61,900 & 21 & 31,500 & 9 & 93,500 & 27.1 \\
\hline Misc. individual & 205,400 & 69 & 276,600 & 80 & 482,000 & 14 \\
\hline Industrial business & 300 & W & 3,000 & 1 & 3,300 & 81 \\
\hline Real estate & 2,200 & 1 & 2,900 & 1 & 5,100 & 46.6 \\
\hline Nonindustrial business & 5,000 & 2 & 3,300 & 1 & 8,300 & 50.7 \\
\hline Sport/ recreation club & 6,500 & 2 & 10,600 & 3 & 17,000 & 61.7 \\
\hline Other & 14,300 & 5 & 8,300 & 2 & 22,600 & 49.1 \\
\hline Total noncorporate & 295,700 & 99 & 336,200 & 97 & 631,900 & 11.5 \\
\hline Total & 299,300 & 100 & 345,200 & 100 & 644,600 & 11.2 \\
\hline SE & 15.4 & & 16.8 & & 11.2 & \\
\hline \multicolumn{7}{|c|}{ (In thousands of acres) } \\
\hline Incorporated: & & & & & & \\
\hline Forest industry & 12,176 & 31 & 0 & 0 & 12,176 & 13.9 \\
\hline Farm & 1,015 & 3 & 730 & 11 & 1,745 & 15.8 \\
\hline Industrial business & 329 & 1 & 182 & 3 & 510 & 58.5 \\
\hline Real estate & 211 & 1 & 172 & 3 & 383 & 31.8 \\
\hline Non-industrial & 59 & W & 0 & 0 & 59 & 100 \\
\hline Sport/ recreation club & 140 & W & 0 & 0 & 140 & 45.6 \\
\hline Public utility & 113 & W & 0 & 0 & 113 & 62 \\
\hline Other & 8,399 & 21 & 152 & 2 & 8,551 & 11.9 \\
\hline Total corporate & 22,443 & 57 & 1,235 & 19 & 23,678 & 7.7 \\
\hline \multicolumn{7}{|l|}{ Unincorporated: } \\
\hline Forest industry & 2,353 & 6 & 0 & 0 & 2,353 & 36.2 \\
\hline Farm & 5,277 & 13 & 1,547 & 23 & 6,823 & 8.3 \\
\hline Misc. individual & 5,635 & 14 & 3,138 & 47 & 8,773 & 12.7 \\
\hline Industrial business & 396 & 1 & 66 & 1 & 462 & 71.2 \\
\hline Real estate & 535 & 1 & 328 & 5 & 863 & 25.1 \\
\hline Nonindustrial business & 161 & W & 32 & W & 193 & 35.6 \\
\hline Sport/ recreation club & 264 & 1 & 87 & 1 & 351 & 29.1 \\
\hline Other & 2,122 & 5 & 214 & 3 & 2,336 & 29.8 \\
\hline Total noncorporate & 16,743 & 43 & 5,412 & 81 & 22,155 & 8.2 \\
\hline Total & 39,186 & 100 & 6,647 & 100 & 45,833 & 0.4 \\
\hline SE & 1.4 & & 8 & & 0.4 & \\
\hline
\end{tabular}

W- Fewer than 50 owners or less than 0.5 percent 


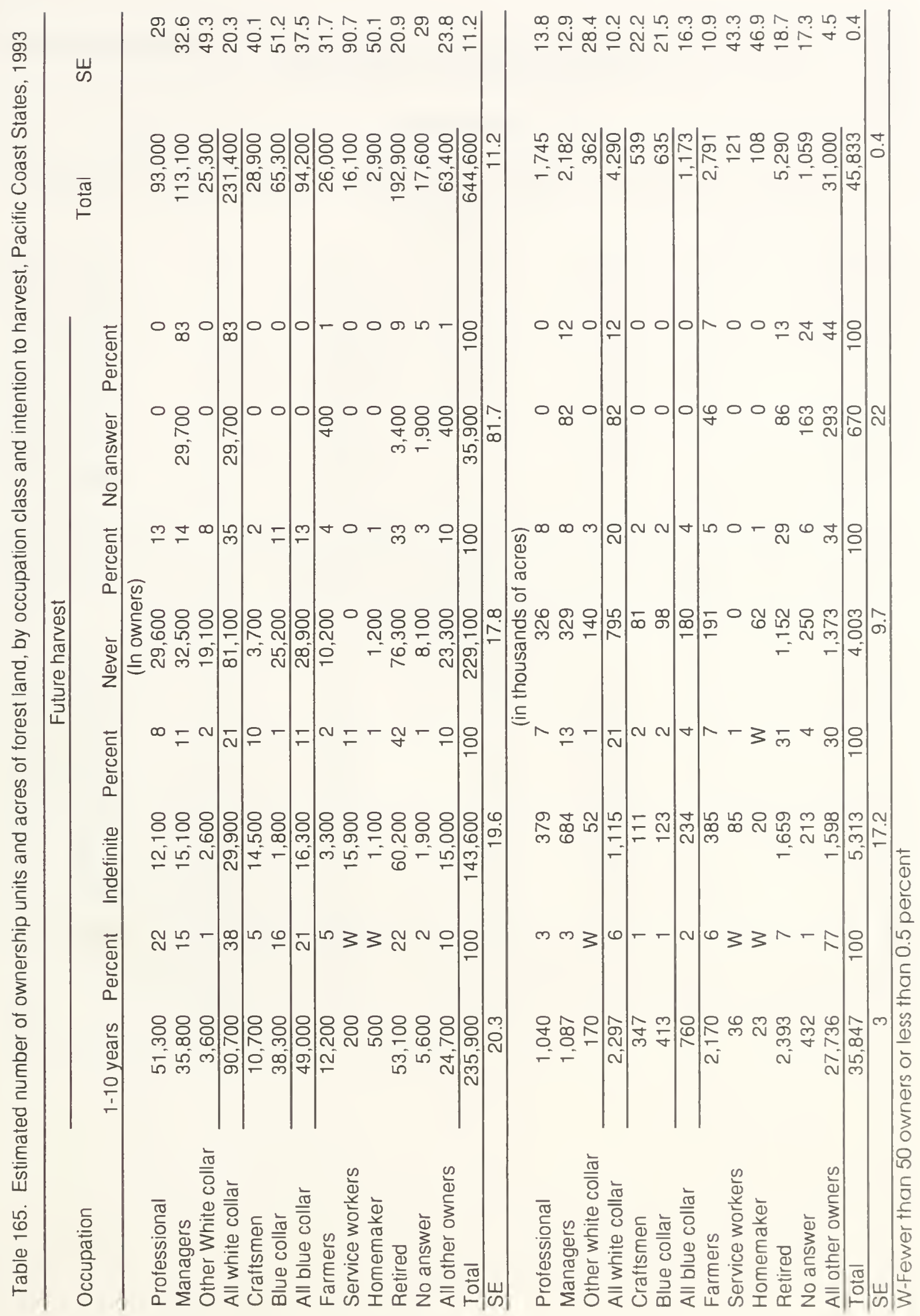


Table 166. Estimated number of ownership units and acres of forest land, by age class and past harvest experience, Pacific Coast States, 1993

\begin{tabular}{|c|c|c|c|c|c|c|}
\hline \multirow[t]{2}{*}{ Age } & \multicolumn{4}{|c|}{ Harvest experience } & \multirow{2}{*}{ Total } & \multirow{2}{*}{ SE } \\
\hline & Harvested & Percent & Did not harvest & Percent & & \\
\hline \multicolumn{7}{|c|}{ (In owners) } \\
\hline Under 25 & 300 & W & 0 & 0 & 300 & 100 \\
\hline $25-34$ & 5,000 & 2 & 3,500 & 1 & 8,500 & 43.7 \\
\hline $35-44$ & 74,700 & 25 & 52,200 & 15 & 126,900 & 26.3 \\
\hline $45-54$ & 29,500 & 10 & 121,600 & 35 & 151,200 & 30 \\
\hline $55-64$ & 56,300 & 19 & 55,100 & 16 & 111,400 & 23.9 \\
\hline 65 or over & 101,400 & 34 & 76,000 & 22 & 177,500 & 21.8 \\
\hline No answer & 3,200 & 1 & 2,300 & 1 & 5,400 & 40.3 \\
\hline All other owners & 28,900 & 10 & 34,500 & 10 & 63,400 & 23.8 \\
\hline Total & 299,300 & 100 & 345,200 & 100 & 644,600 & 11.2 \\
\hline SE & 15.4 & & 16.8 & & 11.2 & \\
\hline \multicolumn{7}{|c|}{ (In thousands of acres) } \\
\hline Under 25 & 23 & W & 0 & 0 & 23 & 100 \\
\hline $25-34$ & 122 & W & 94 & 1 & 217 & 33.9 \\
\hline $35-44$ & 1,182 & 3 & 612 & 9 & 1,795 & 13.7 \\
\hline $45-54$ & 1,412 & 4 & 1,252 & 19 & 2,663 & 11.5 \\
\hline $55-64$ & 1,967 & 5 & 975 & 15 & 2,942 & 11.4 \\
\hline 65 or over & 5,531 & 14 & 1,309 & 20 & 6,840 & 15.2 \\
\hline No answer & 145 & W & 208 & 3 & 353 & 27.7 \\
\hline All other owners & 28,803 & 73 & 2,197 & 33 & 31,000 & 4.5 \\
\hline Total & 39,186 & 100 & 6,647 & 100 & 45,833 & 0.4 \\
\hline$\overline{S E}$ & 1.4 & & 8 & & 0.4 & \\
\hline
\end{tabular}

W-Fewer than 50 owners of less than 0.5 percent 
Table 167. Estimated number of ownership units and acres of forest land, by date of aquisition and form of ownership, Pacific Coast States, 1993

\begin{tabular}{|c|c|c|c|c|c|c|c|}
\hline \multirow[b]{2}{*}{$\begin{array}{c}\text { Date of } \\
\text { acquisition }\end{array}$} & \multicolumn{5}{|c|}{ Ownership class } & \multirow[b]{2}{*}{ Total } & \multirow[b]{2}{*}{ SE } \\
\hline & $\begin{array}{c}\text { Forest } \\
\text { industry }\end{array}$ & Farmer & $\begin{array}{l}\text { Miscellaneous: } \\
\text { Individual }\end{array}$ & Corporation & Other & & \\
\hline \multicolumn{8}{|c|}{ (In owners) } \\
\hline $1990-1994$ & W & 4,600 & 107,700 & 2,800 & 7,100 & 122,200 & 31.3 \\
\hline $1980-1989$ & 100 & 22,900 & 167,700 & 2,000 & 13,900 & 206,500 & 21.7 \\
\hline $1970-1979$ & 200 & 17,500 & 97,000 & 500 & 12,000 & 127,200 & 21.5 \\
\hline $1960-1969$ & 300 & 8,100 & 54,400 & W & $6,40 Q$ & 69,100 & 27.9 \\
\hline $1950-1959$ & 100 & 30,000 & 34,800 & 200 & 2,400 & 67,400 & 37.8 \\
\hline $1940-1949$ & 100 & 10,600 & 8,100 & W & W & 18,900 & 25.6 \\
\hline $1901-1939$ & W & 2,700 & 2,400 & 600 & 1,400 & 7,000 & 26.4 \\
\hline Prior to 1900 & 100 & 300 & 1,100 & 0 & 100 & 1,600 & 43.8 \\
\hline No answer & 300 & 2,300 & 21,100 & 200 & 600 & 24,500 & 77.1 \\
\hline Total & 1,000 & 98,900 & 494,300 & 6,400 & 44,000 & 644,600 & 11.2 \\
\hline SE & 36.1 & 25.7 & 13.6 & 47.5 & 33.3 & 11.2 & \\
\hline \multicolumn{8}{|c|}{ (In thousands of acres) } \\
\hline $1990-1994$ & 171 & 446 & 845 & 62 & 144 & 1,668 & 16.1 \\
\hline $1980-1989$ & 426 & 1,234 & 1,704 & 2,490 & 436 & 6,290 & 20.9 \\
\hline $1970-1979$ & 261 & 1,740 & 2,052 & 6,453 & 285 & 10,791 & 14.5 \\
\hline $1960-1969$ & 370 & 1,322 & 1,167 & 87 & 255 & 3,201 & 12.2 \\
\hline $1950-1959$ & 1,178 & 1,290 & 2,356 & 147 & 129 & 5,099 & 21.7 \\
\hline $1940-1949$ & 1,781 & 699 & 544 & 66 & 29 & 3,119 & 21.1 \\
\hline $1901-1939$ & 2,020 & 745 & 238 & 215 & 802 & 4,021 & 18.9 \\
\hline Prior to 1900 & 8,202 & 554 & 104 & 63 & 1,487 & 10,410 & 17 \\
\hline No answer & 120 & 538 & 252 & 172 & 149 & 1,231 & 20.7 \\
\hline Total & 14,529 & 8,569 & 9,262 & 9,756 & 3,716 & 45,833 & 0.4 \\
\hline SE & 10.5 & 7.6 & 12.2 & 10.2 & 21.1 & 0.4 & \\
\hline
\end{tabular}

W-fewer than 50 owners or less than 0.5 percent 
Table 168. Estimated number of ownership units and acres of forest land, by distance from tracts, Pacific Coast States, 1993

\begin{tabular}{|c|c|c|c|c|}
\hline \multirow[t]{3}{*}{ Distance } & \multicolumn{3}{|c|}{ Tracts } & \multirow{3}{*}{ Total } \\
\hline & \multirow[b]{2}{*}{1 tract } & \multicolumn{2}{|c|}{ More than one tract } & \\
\hline & & Nearest tract & Farthest tract & \\
\hline \multicolumn{5}{|c|}{ (In owners) } \\
\hline Less than 1 mile & 300,400 & 68,300 & 38,500 & \\
\hline $2-5$ miles & 16,300 & 7,200 & 8,500 & \\
\hline $6-15$ miles & 12,500 & 4,900 & 9,000 & \\
\hline $16-25$ miles & 17,900 & 2,600 & 3,900 & \\
\hline 26-50 miles & 12,300 & 7,100 & 10,000 & \\
\hline $51-100$ miles & 7,800 & 3,400 & 5,500 & \\
\hline More than 100 miles & 155,100 & 12,900 & 31,000 & \\
\hline No answer & 12,000 & 3,900 & 3,900 & \\
\hline Total & 534,400 & 110,200 & 110,200 & 644,600 \\
\hline \multicolumn{5}{|c|}{ (In thousands of acres) } \\
\hline Less than 1 mile & 5,234 & 13,991 & 1,365 & \\
\hline 2-5 miles & 437 & 4,581 & 1,239 & \\
\hline 6-15 miles & 383 & 5,453 & 2,505 & \\
\hline $16-25$ miles & 185 & 889 & 2,287 & \\
\hline 26-50 miles & 795 & 5,614 & 3,072 & \\
\hline $51-100$ miles & 544 & 637 & 5,496 & \\
\hline More than 100 miles & 2,072 & 2,165 & 17,379 & \\
\hline No answer & 737 & 2,115 & 2,101 & \\
\hline Total & 10,387 & 35,445 & 35,445 & 45,833 \\
\hline
\end{tabular}


Table 169. Estimated number of ownership units and acres of forest land, by primary and secondary reason for owning forest land, Pacific Coast States, 1993

\begin{tabular}{|c|c|c|c|c|}
\hline \multirow[t]{2}{*}{ Reason } & \multicolumn{2}{|l|}{ Primary reason } & \multicolumn{2}{|c|}{ Secondary reason } \\
\hline & Number & Percent & Number & Percent \\
\hline & \multicolumn{4}{|c|}{ (In owners) } \\
\hline Land investment & 77,900 & 12 & 8,800 & 1 \\
\hline Recreation & 52,400 & 8 & 44,700 & 7 \\
\hline Timber production & 13,600 & 2 & 12,500 & 2 \\
\hline Farm and domestic use & 21,100 & 3 & 51,800 & 8 \\
\hline Esthetic enjoyment & 129,100 & 20 & 95,400 & 15 \\
\hline Part of farm & 56,700 & 9 & 8,400 & 1 \\
\hline Part of residence & 136,100 & 21 & 72,500 & 11 \\
\hline Estate & 73,200 & 11 & 86,800 & 14 \\
\hline Other & 80,500 & 13 & 9,200 & 1 \\
\hline No secondary reason given & - & - & 250,600 & 39 \\
\hline No answer & 3,800 & 1 & 3,800 & 1 \\
\hline \multirow[t]{2}{*}{ Total } & 644,600 & 100 & 644,600 & 100 \\
\hline & \multicolumn{4}{|c|}{ (In thousands of acres) } \\
\hline Land investment & 2,804 & 6 & 4,946 & 11 \\
\hline Recreation & 2,705 & 6 & 2,945 & 6 \\
\hline Timber production & 17,967 & 39 & 2,285 & 5 \\
\hline Farm and domestic use & 2,871 & 6 & 5,140 & 11 \\
\hline Esthetic enjoyment & 2,047 & 5 & 3,090 & 7 \\
\hline Part of farm & 2,548 & 6 & 875 & 2 \\
\hline Part of residence & 2,470 & 5 & 1,640 & 4 \\
\hline Estate & 1,929 & 4 & 3,928 & 9 \\
\hline Other & 9,268 & 20 & 1,345 & 3 \\
\hline No secondary reason given & - & - & 18,414 & 40 \\
\hline No answer & 1,223 & 3 & 1,223 & 3 \\
\hline Total & 45,833 & 100 & 45,833 & 100 \\
\hline
\end{tabular}


Table 170. Estimated number of ownership units and acres of forest land, by primary benefit expected in the next 10 years and past harvest experience, Pacific Coast States, 1993

\begin{tabular}{|c|c|c|c|c|c|c|}
\hline \multirow[t]{2}{*}{ Benefits expected } & \multicolumn{4}{|c|}{ Harvest Experience } & \multirow{2}{*}{ Total } & \multirow{2}{*}{ SE } \\
\hline & Harvested & Percent & Did not harvest & Percent & & \\
\hline \multicolumn{7}{|c|}{ (In owners) } \\
\hline Land value increase & 60,500 & 20 & 104,100 & 30 & 164,600 & 25.1 \\
\hline Recreation & 11,300 & 4 & 59,100 & 17 & 70,400 & 46.3 \\
\hline Income from timber & 12,000 & 4 & 6.200 & 2 & 18,200 & 21.4 \\
\hline Farm and domestic us $€$ & 37,600 & 13 & 18,800 & 5 & 56,400 & 29.5 \\
\hline Esthetic enjoyment & 125,000 & 42 & 116.900 & 34 & 241,900 & 17.4 \\
\hline Firewood & 24,200 & 8 & 500 & W & 24,600 & 93.3 \\
\hline Other & 15,600 & 5 & 25,400 & 7 & 41,000 & 28.4 \\
\hline No answer & 13,200 & 4 & 14,200 & 4 & 27,400 & 42.1 \\
\hline Total & 299,300 & 100 & 345,200 & 100 & 644,600 & 11.2 \\
\hline SE & 15.4 & & 16.8 & & 11.2 & \\
\hline \multicolumn{7}{|c|}{ (In thousands of acres) } \\
\hline Land value increase & 2,003 & 5 & 1,752 & 26 & 3,755 & 10.5 \\
\hline Recreation & 2,648 & 7 & 862 & 13 & 3,510 & 33.6 \\
\hline Income from timber & 19,453 & 50 & 466 & 7 & 19,918 & 8.1 \\
\hline Farm and domestic us $\epsilon$ & 2,307 & 6 & 477 & 7 & 2,784 & 11.2 \\
\hline Esthetic enjoyment & 3,472 & 9 & 1,747 & 26 & 5,220 & 17.8 \\
\hline Firewood & 165 & w & 14 & w & 179 & 32.2 \\
\hline Other & 7,154 & 18 & 789 & 12 & 7,943 & 21.7 \\
\hline No answer & 1,985 & 5 & 540 & 8 & 2,525 & 39.6 \\
\hline Total & 39,186 & 100 & 6,647 & 100 & 45,833 & 0.4 \\
\hline SE & 1.4 & & 8 & & 0.4 & \\
\hline
\end{tabular}




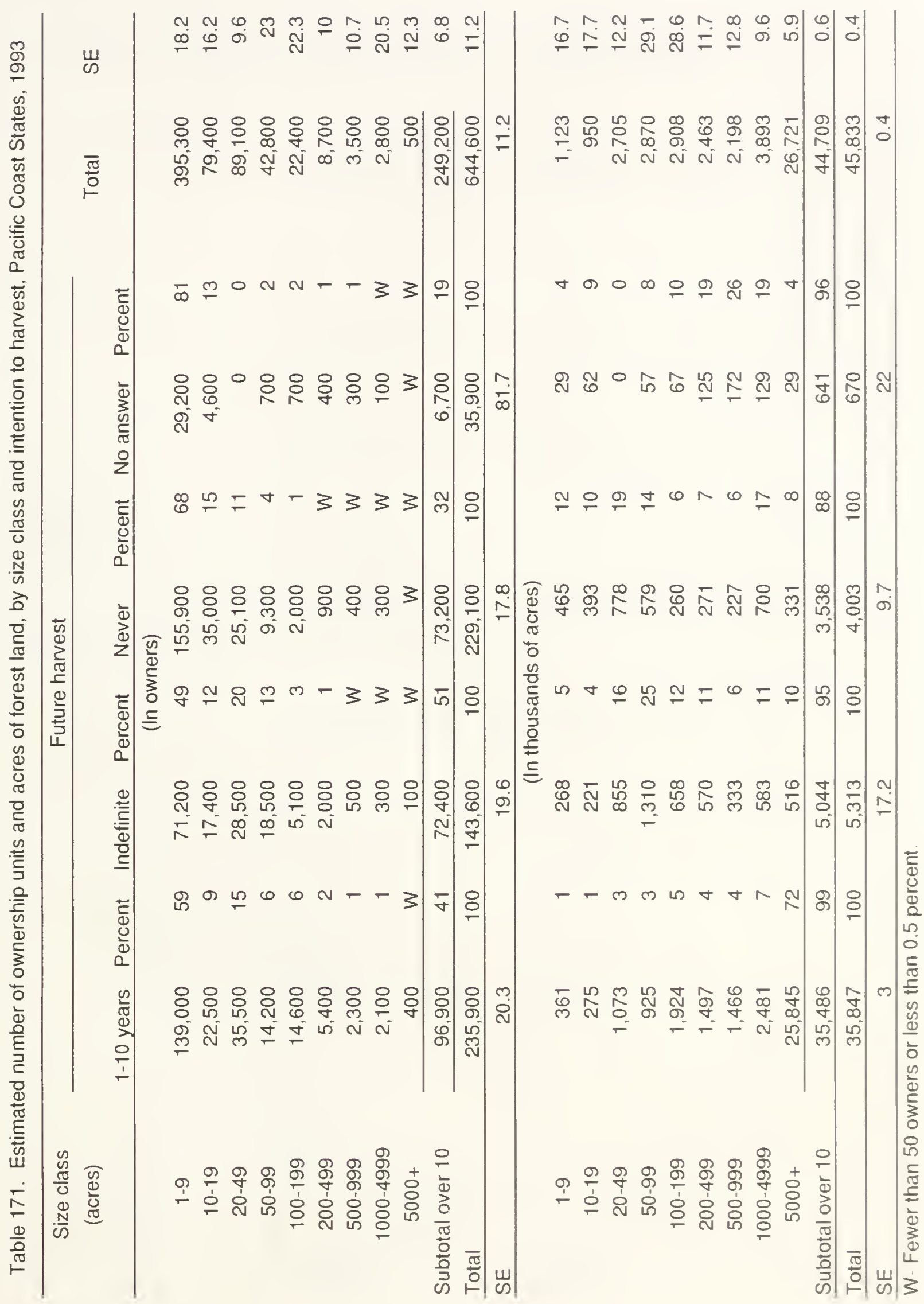




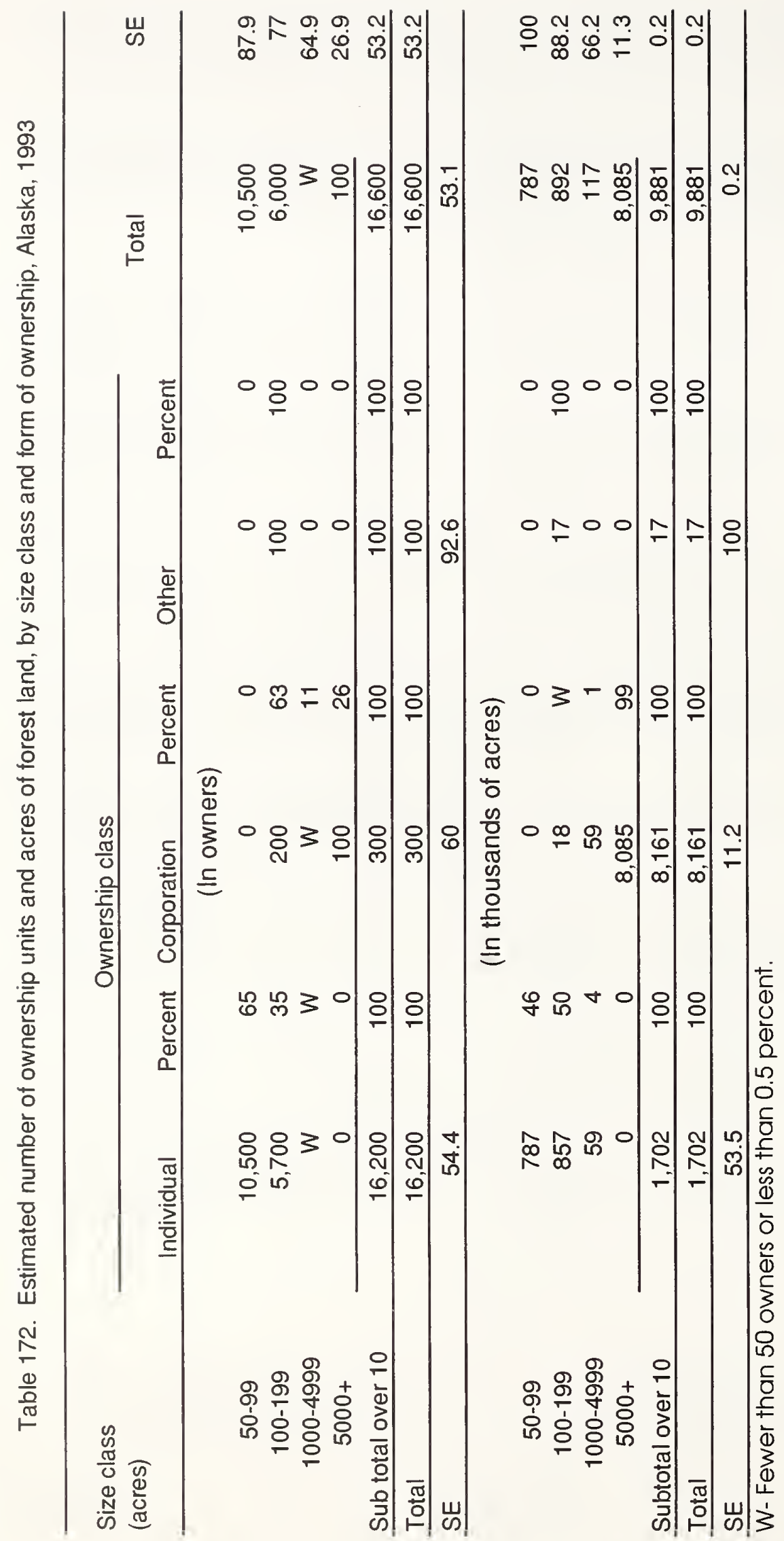


Table 173. Estimated number of ownership units and acres of forest land, by form of ownership and past harvest experience. Alaska, 1993

Form of ownership

Harvest experience

Harvested Percent Did not havest Percent

Total

SE

(In owners)

Individual + joint

Corporation

16,100

98

300

100

100

$16.200 \quad 54.4$

Club/Association

100

2

W

$300 \quad 59.6$

Total

100

1

0

$100 \quad 92.6$

SE

16,500

100

100

100

$16.600 \quad 53.1$

53.5

92.5

53.1

(In thousands of acres)

Individual + joint

1,685

17

17

37

1.702

53.5

Corporation

8,131

83

30

63

$8.161 \quad 11.2$

Club/association

$17 \mathrm{~W}$

$0 \quad 0$

$17 \quad 100$

Total

9,834

100

47

100

$9,881 \quad 0.2$

SE

0.4

81.7

0.2

W-Fewer than 50 owners or less than 0.5 percent 
Table 174. Estimated number of ownership units and acres of forest land, by incorporated and unincorporated businesses and past harvest experience, Alaska, 1993

\begin{tabular}{|c|c|c|c|c|c|c|}
\hline \multirow[t]{2}{*}{ Nature of business } & \multicolumn{4}{|c|}{ Harvest } & \multirow{2}{*}{ Total } & \multirow{2}{*}{ SE } \\
\hline & Harvested & Percent & Did not harvest & Percent & & \\
\hline \multicolumn{7}{|c|}{ (In owners) } \\
\hline \multicolumn{7}{|l|}{ Incorporated: } \\
\hline Forest industry & W & W & 0 & 0 & W & 94.1 \\
\hline Industrial business & W & W & 0 & 0 & W & 78.8 \\
\hline Non-industrial & W & W & 0 & 0 & W & 95.7 \\
\hline Other & 200 & 1 & W & W & 200 & 68.9 \\
\hline Total corporate & 300 & 1 & $W$ & $W$ & 300 & 59.6 \\
\hline \multicolumn{7}{|l|}{ Unincorporated: } \\
\hline Misc. individual & 16,100 & 98 & 100 & 100 & 16,200 & 54.4 \\
\hline Other & 100 & 1 & 0 & 0 & 100 & 92.6 \\
\hline Total noncorporate & 16,200 & 99 & 100 & 100 & 16,300 & 54.1 \\
\hline Total & 16,500 & 100 & 100 & 100 & 16,600 & 53.1 \\
\hline SE & 53.5 & & 92.5 & & 53.1 & \\
\hline \multicolumn{7}{|c|}{ (In thousands of acres) } \\
\hline Incorporated: & & & & & & \\
\hline Forest industry & 139 & 1 & 0 & 0 & 139 & 67.3 \\
\hline Industrial business & 306 & 3 & 0 & 0 & 306 & 92.6 \\
\hline Non-industrial & 59 & 1 & 0 & 0 & 59 & 100 \\
\hline Other & 7,628 & 77 & 30 & 63 & 7,658 & 12.6 \\
\hline Total corporate & 8,131 & 83 & 30 & 63 & 8,161 & 11.2 \\
\hline \multicolumn{7}{|l|}{ Unincorporated: } \\
\hline Misc. individual & 1,685 & 17 & 17 & 37 & 1,702 & 53.5 \\
\hline Other & 17 & W & 0 & 0 & 17 & 100 \\
\hline Total noncorporate & 1,702 & 17 & 17 & 37 & 1,720 & 52.9 \\
\hline Total & 9,834 & 100 & 47 & 100 & 9,881 & 0.2 \\
\hline SE & 0.4 & & 81.7 & & 0.2 & \\
\hline
\end{tabular}

W- Fewer than 50 owners or less than 0.5 percent 


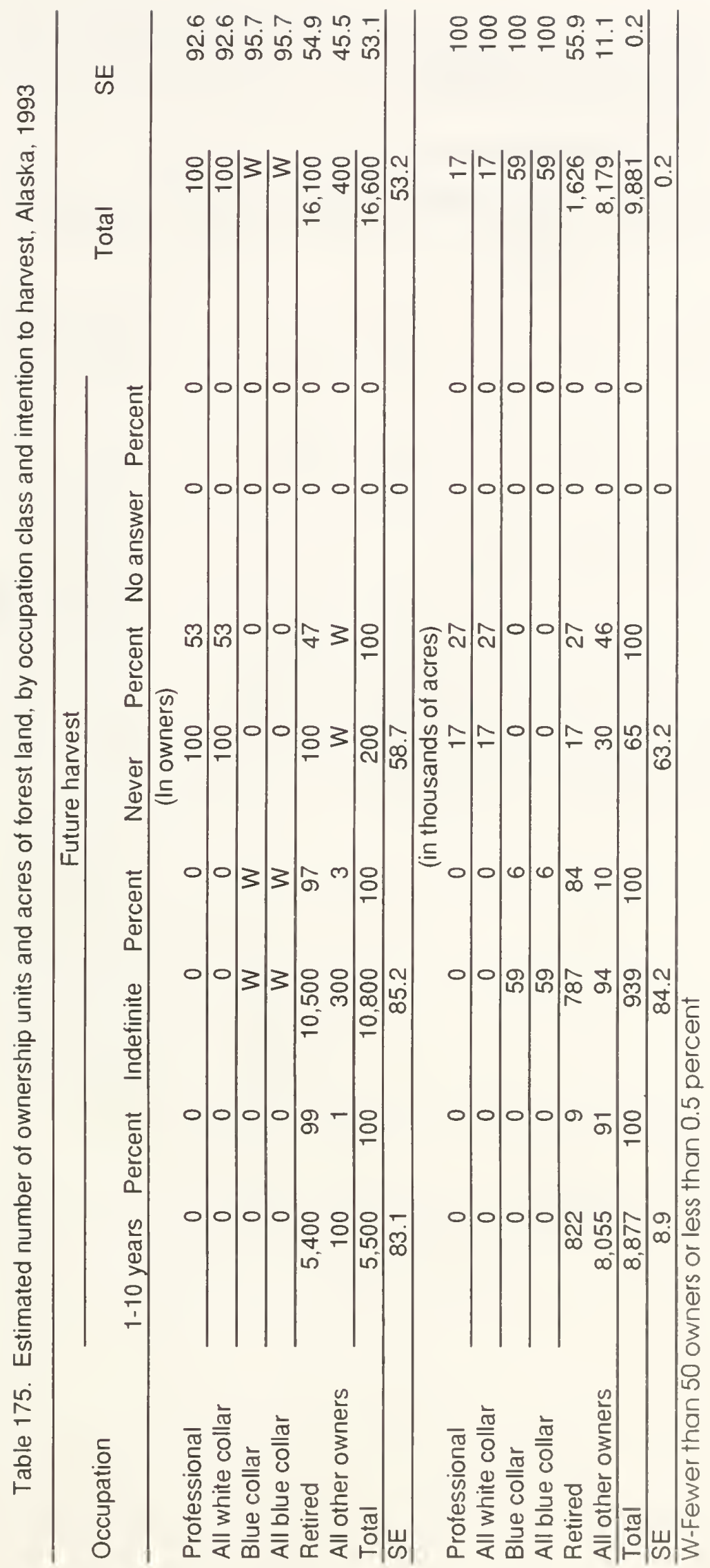


Table 176. Estimated number of ownership units and acres of forest land, by age class and past harvest experience, Alaska, 1993

\begin{tabular}{|c|c|c|c|c|c|c|}
\hline \multirow[t]{2}{*}{ Age } & \multicolumn{4}{|c|}{ Harvest experience } & \multirow{2}{*}{ Total } & \multirow{2}{*}{ SE } \\
\hline & Harvested & Percent & Did not harvest & Percent & & \\
\hline \multicolumn{7}{|c|}{ (In owners) } \\
\hline $35-44$ & W & W & 0 & 0 & W & 95.7 \\
\hline 65 or over & 16,100 & 97 & 100 & 100 & 16,200 & 54.5 \\
\hline All other owners & 400 & 2 & W & W & 400 & 45.5 \\
\hline Total & 16,500 & 100 & 100 & 100 & 16,600 & 53.1 \\
\hline SE & 53.5 & & 92.5 & & 53.1 & \\
\hline \multicolumn{7}{|c|}{ (In thousands of acres) } \\
\hline $35-44$ & 59 & 1 & 0 & 0 & 59 & 100 \\
\hline 65 or over & 1,626 & 17 & 17 & 37 & 1,644 & 55.3 \\
\hline All other owners & 8,149 & 83 & 30 & 63 & 8,179 & 11.1 \\
\hline Total & 9,834 & 100 & 47 & 100 & 9,881 & 0.2 \\
\hline SE & 0.4 & & 81.7 & & 0.2 & \\
\hline
\end{tabular}

W-Fewer than 50 owners of less than 0.5 percent 
Table 177. Estimated number of ownership units and acres of forest land, by date of aquisition and form of ownership, Alaska, 1993

\begin{tabular}{|c|c|c|c|c|c|c|c|}
\hline \multirow[b]{2}{*}{$\begin{array}{l}\text { Date of } \\
\text { acquisition }\end{array}$} & \multicolumn{5}{|c|}{ Ownership class } & \multirow[b]{2}{*}{ Total } & \multirow[b]{2}{*}{ SE } \\
\hline & $\begin{array}{l}\text { Forest } \\
\text { industry }\end{array}$ & Farmer & $\begin{array}{l}\text { Miscellaneous: } \\
\text { Individual }\end{array}$ & Corporation & Other & & \\
\hline \multicolumn{8}{|c|}{ (In owners) } \\
\hline $1990-1994$ & 0 & 0 & 0 & 0 & 0 & 0 & 0 \\
\hline $1980-1989$ & 0 & 0 & 0 & W & 0 & W & 52.3 \\
\hline $1970-1979$ & W & 0 & 200 & 0 & 0 & 300 & 41.8 \\
\hline $1960-1969$ & 0 & 0 & 200 & 0 & 0 & 200 & 58.8 \\
\hline $1950-1959$ & 0 & 0 & 15,700 & 0 & 0 & 15,700 & 56.1 \\
\hline $1940-1949$ & 0 & 0 & 0 & 0 & 0 & 0 & 0 \\
\hline $1901-1939$ & 0 & 0 & 0 & 200 & 0 & 200 & 92.6 \\
\hline Prior to 1900 & 0 & 0 & 0 & 0 & 0 & 0 & 0 \\
\hline No answer & 0 & 0 & W & 0 & 100 & 100 & 79.9 \\
\hline Total & W & 0 & 16,200 & 200 & 100 & 16,600 & 53.1 \\
\hline SE & 94.1 & 0 & 54.4 & 66 & 92.6 & 53.1 & \\
\hline \multicolumn{8}{|c|}{ (In thousands of acres) } \\
\hline $1990-1994$ & 0 & 0 & 0 & 0 & 0 & 0 & 0 \\
\hline 1980-1989 & 31 & 0 & 0 & 1,729 & 0 & 1,760 & 68.2 \\
\hline $1970-1979$ & 108 & 0 & 35 & 6,276 & 0 & 6,419 & 23.5 \\
\hline $1960-1969$ & 0 & 0 & 35 & 0 & 0 & 35 & 63.4 \\
\hline $1950-1959$ & 0 & 0 & 1,537 & 0 & 0 & 1,573 & 57.7 \\
\hline $1940-1949$ & 0 & 0 & 0 & 0 & 0 & 0 & 0 \\
\hline $1901-1939$ & 0 & 0 & 0 & 17 & 0 & 17 & 100 \\
\hline Prior to 1900 & 0 & 0 & 0 & 0 & 0 & 0 & 0 \\
\hline No answer & 0 & 0 & 59 & 0 & 17 & 76 & 80.4 \\
\hline Total & 139 & 0 & 1,702 & 8,022 & 17 & 9,881 & 0.2 \\
\hline SE & 67.3 & 0 & 53.5 & 11.4 & 100 & 0.2 & \\
\hline
\end{tabular}

W-fewer than 50 owners or less than 0.5 percent 
Table 178. Estimated number of ownership units and acres of forest land, by distance from tracts, Alaska, 1993

\begin{tabular}{|c|c|c|c|c|}
\hline \multirow[t]{3}{*}{ Distance } & \multicolumn{3}{|c|}{ Tracts } & \multirow{3}{*}{ Total } \\
\hline & \multirow[b]{2}{*}{1 tract } & \multicolumn{2}{|c|}{ More than one tract } & \\
\hline & & Nearest tract & Farthest tract & \\
\hline \multicolumn{5}{|c|}{ (In owners) } \\
\hline Less than 1 mile & 10,800 & 5,500 & 0 & \\
\hline $2-5$ miles & 100 & W & 0 & \\
\hline $6-15$ miles & W & W & W & \\
\hline $16-25$ miles & 0 & 0 & 100 & \\
\hline $26-50$ miles & 0 & W & W & \\
\hline $51-100$ miles & 0 & 0 & W & \\
\hline More than 100 miles & 0 & W & 5,400 & \\
\hline No answer & 100 & 0 & 0 & \\
\hline Total & 11,100 & 5,500 & 5,500 & 16,600 \\
\hline \multicolumn{5}{|c|}{ (In thousands of acres) } \\
\hline Less than 1 mile & 847 & 3,535 & 0 & \\
\hline $2-5$ miles & 17 & 90 & 0 & \\
\hline $6-15$ miles & 59 & 1,059 & 1,074 & \\
\hline $16-25$ miles & 0 & 0 & 1,347 & \\
\hline $26-50$ miles & 0 & 3,386 & 1,099 & \\
\hline $51-100$ miles & 0 & 0 & 418 & \\
\hline More than 100 miles & 0 & 872 & 5,003 & \\
\hline No answer & 17 & 0 & 0 & \\
\hline Total & 940 & 8,941 & 8,941 & 9,881 \\
\hline
\end{tabular}


Table 179. Estimated number of ownership units and acres of forest land, by primary and secondary reason for owning forest land, Alaska, 1993

\begin{tabular}{|c|c|c|c|c|}
\hline \multirow[t]{2}{*}{ Reason } & \multicolumn{2}{|c|}{ Primary reason } & \multicolumn{2}{|c|}{ Secondary reason } \\
\hline & Number & Percent & Number & Percent \\
\hline & \multicolumn{4}{|c|}{ (In owners) } \\
\hline Land investment & 0 & 0 & 0 & 0 \\
\hline Recreation & 10,600 & 64 & W & W \\
\hline Timber production & W & W & W & W \\
\hline Farm and domestic use & W & W & 10,500 & 63 \\
\hline Esthetic enjoyment & 100 & 1 & 5,200 & 31 \\
\hline Part of farm & 0 & 0 & 0 & 0 \\
\hline Part of residence & 5,300 & 32 & W & W \\
\hline Estate & 100 & 1 & W & W \\
\hline Other & 400 & 2 & W & W \\
\hline No secondary reason given & - & - & 800 & 5 \\
\hline No answer & 0 & 0 & 0 & 0 \\
\hline \multirow[t]{2}{*}{ Total } & 16,600 & 100 & 16,600 & 100 \\
\hline & \multicolumn{4}{|c|}{ (In thousands of acres) } \\
\hline Land investment & 0 & 0 & 0 & 0 \\
\hline Recreation & 863 & 9 & 1,000 & 10 \\
\hline Timber production & 466 & 5 & 306 & 3 \\
\hline Farm and domestic use & 1,000 & 10 & 3,587 & 36 \\
\hline Esthetic enjoyment & 17 & W & 787 & 8 \\
\hline Part of farm & 0 & 0 & 0 & 0 \\
\hline Part of residence & 845 & 9 & 525 & 5 \\
\hline Estate & 632 & 6 & 265 & 3 \\
\hline Other & 6,057 & 61 & 233 & 2 \\
\hline No secondary reason given & - & - & 3,179 & 32 \\
\hline No answer & 0 & 0 & 0 & 0 \\
\hline Total & 9,881 & 100 & 9,881 & 100 \\
\hline
\end{tabular}

W-Fewer than 50 owners or less than 0.5 percent 
Table 180. Estimated number of ownership units and acres of forest land, by primary benefit expected in the next 10 years and past harvest experience, Alaska, 1993

\begin{tabular}{|c|c|c|c|c|c|c|}
\hline \multirow[t]{2}{*}{ Benefits expected } & \multicolumn{4}{|c|}{ Harvest Experience } & \multirow{2}{*}{ Total } & \multirow{2}{*}{ SE } \\
\hline & Harvested & Percent & Did not harvest & Percent & & \\
\hline \multicolumn{7}{|c|}{ (In owners) } \\
\hline Land value increase & 100 & 1 & 0 & 0 & 100 & 92.6 \\
\hline Recreation & 100 & 1 & 0 & 0 & 100 & 77.7 \\
\hline Income from timber & 100 & w & 0 & 0 & 100 & 47.2 \\
\hline Farm and domestic use & 0 & 0 & 0 & 0 & 0 & 0 \\
\hline Esthetic enjoyment & 5,400 & 33 & 100 & 100 & 5,500 & 83.2 \\
\hline Firewood & 200 & 1 & 0 & 0 & 200 & 58.6 \\
\hline Other & W & w & W & W & W & 42.9 \\
\hline No answer & 10,500 & 64 & 0 & 0 & 10,500 & 87.9 \\
\hline Total & 16,500 & 100 & 100 & 100 & 16,600 & 53.1 \\
\hline SE & 53.4 & & 92.5 & & 53.1 & \\
\hline \multicolumn{7}{|c|}{ (In thousands of acres) } \\
\hline Land value increase & 17 & W & $1 \quad 0$ & 0 & 17 & 100 \\
\hline Recreation & 1,601 & 16 & 0 & 0 & 1,601 & 71.9 \\
\hline Income from timber & 1,648 & 17 & 0 & 0 & 1,648 & 54 \\
\hline Farm and domestic us $\epsilon$ & 0 & 0 & 0 & 0 & 0 & 0 \\
\hline Esthetic enjoyment & 804 & 8 & 17 & 37 & 822 & 95.8 \\
\hline Firewood & W & w & 0 & 0 & 35 & 63.4 \\
\hline Other & 4,941 & 50 & 30 & 63 & 4,971 & 30.5 \\
\hline No answer & 787 & 8 & 0 & 0 & 787 & 100 \\
\hline Total & 9,834 & 100 & 47 & 100 & 9,881 & 0.2 \\
\hline $\mathrm{SE}$ & 0.4 & & 8 & & 0.2 & \\
\hline
\end{tabular}

W-fewer than 50 owners or less than 0.5 percent 


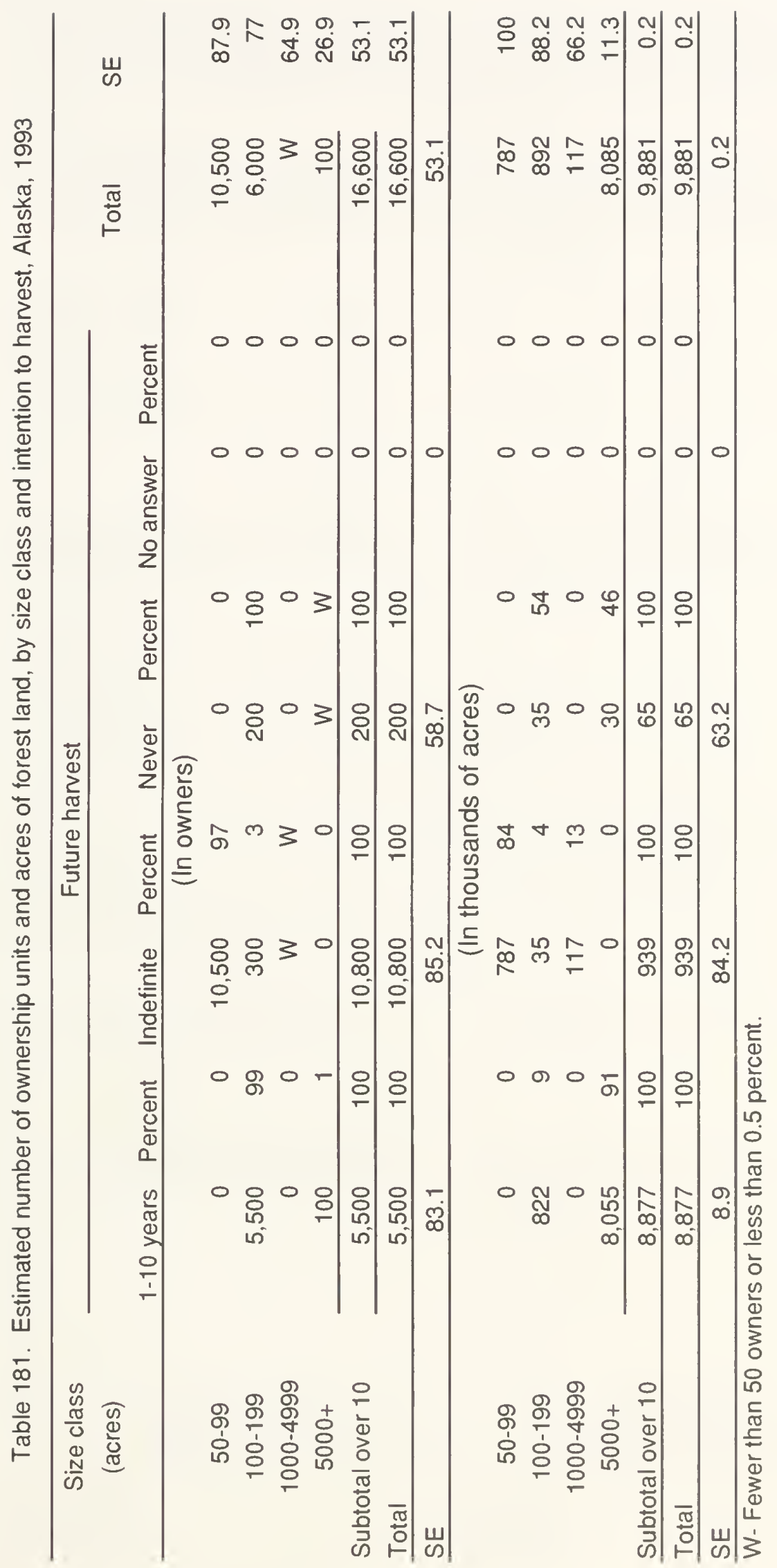




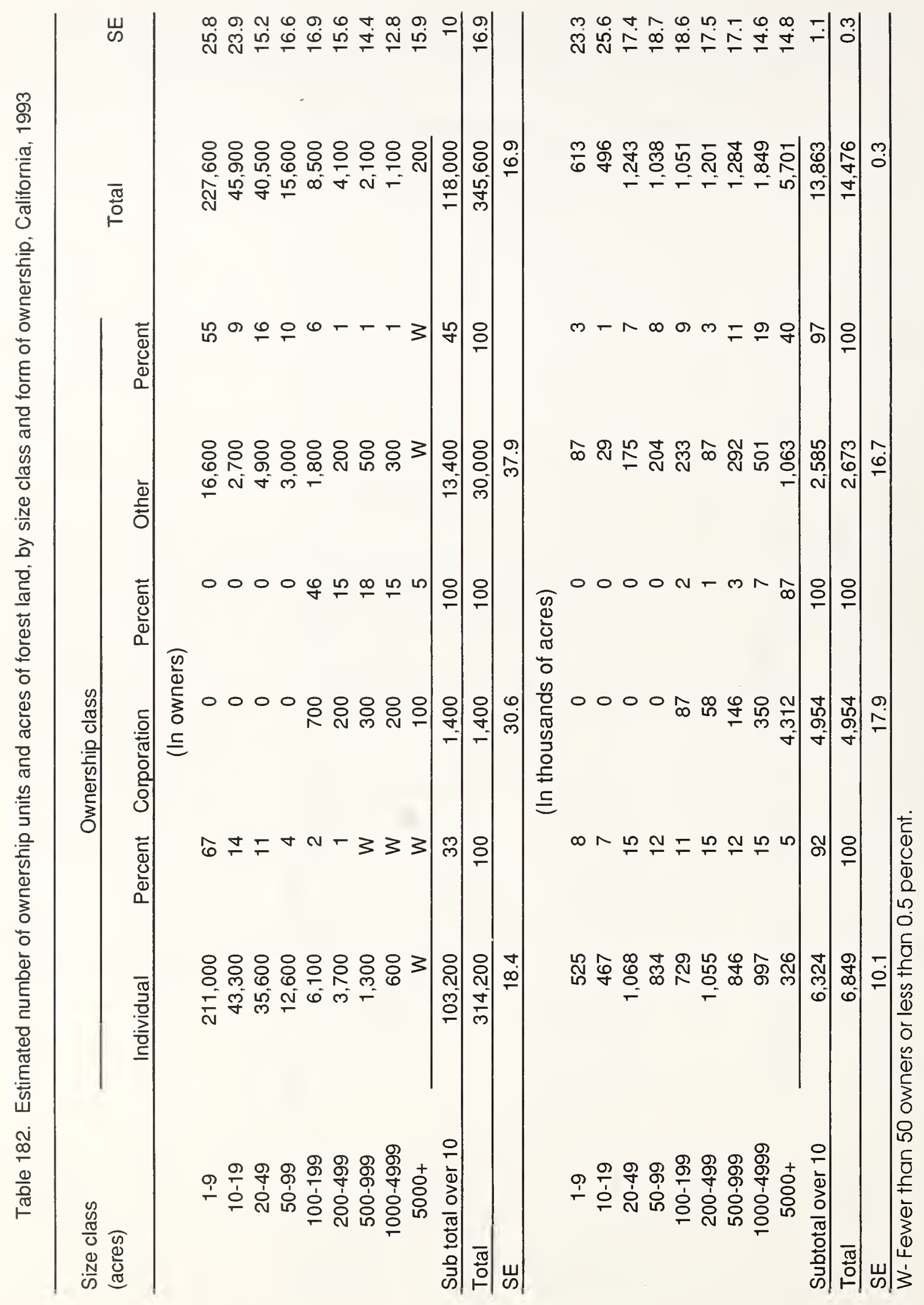


Table 183. Estimated number of ownership units and acres of forest land, by form of ownership and past harvest experience, California, 1993

Form of ownership

Harvest experience

Harvested Percent Did notharvest Percent

Total

SE

(In owners)

\begin{tabular}{|c|c|c|c|c|c|c|}
\hline Individual + joint & 129,300 & 92 & 184,900 & 90 & 314,200 & 18.4 \\
\hline Partnership & 7,400 & 5 & 8,900 & 4 & 16,400 & 35.4 \\
\hline Corporation & 1,000 & 1 & 400 & W & 1,400 & 30.6 \\
\hline Club/association & 400 & W & 10,500 & 5 & 10,900 & 89.4 \\
\hline Other & 1,800 & 1 & 900 & $W$ & 2,700 & 46.9 \\
\hline Total & 139,900 & 100 & 205,800 & 100 & 345,600 & 16.9 \\
\hline SE & 22.7 & & 24.7 & & 16.9 & \\
\hline \multicolumn{7}{|c|}{ (In thousands of acres) } \\
\hline Individual + joint & 4,037 & 38 & 2,811 & 74 & 6,849 & 10.1 \\
\hline Partnership & 1,214 & 11 & 438 & 11 & 1,652 & 17.3 \\
\hline Corporation & 4,587 & 43 & 367 & 10 & 4,954 & 17.9 \\
\hline Club/association & 58 & 1 & 58 & 1 & 117 & 50.7 \\
\hline Other & 800 & 7 & 105 & 3 & 904 & 38.4 \\
\hline Total & 10,697 & 100 & 3,779 & 100 & 14,476 & 0.3 \\
\hline SE & 4.1 & & 11.5 & & 0.3 & \\
\hline
\end{tabular}

W-Fewer than 50 owners or less than 0.5 percent 
Table 184. Estimated number of ownership units and acres of forest land, by incorporated and unincorporated businesses and past harvest experience, California, 1993

\begin{tabular}{|c|c|c|c|c|c|c|}
\hline \multirow[t]{2}{*}{ Nature of business } & \multicolumn{4}{|c|}{ Harvest } & \multirow{2}{*}{ Total } & \multirow{2}{*}{ SE } \\
\hline & Harvested & Percent & Did not harvest & Percent & & \\
\hline \multicolumn{7}{|c|}{ (In owners) } \\
\hline \multicolumn{7}{|l|}{ Incorporated: } \\
\hline Forest industry & 200 & W & 0 & 0 & 200 & 82.9 \\
\hline Farm & 500 & W & 300 & W & 800 & 45 \\
\hline Real estate & W & W & 100 & W & 200 & 91.6 \\
\hline Sport/ recreation club & W & W & 0 & 0 & W & 56.7 \\
\hline Public utility & W & W & 0 & 0 & W & 100 \\
\hline Other & 200 & W & W & W & 200 & 44.1 \\
\hline Total corporate & 1,000 & 1 & 400 & W & 1,400 & 30.6 \\
\hline \multicolumn{7}{|l|}{ Unincorporated: } \\
\hline Forest industry & W & W & 0 & 0 & W & 72.2 \\
\hline Farm & 10,500 & 7 & 10,700 & 5 & 21,200 & 22.1 \\
\hline Misc. individual & 116,500 & 83 & 174,500 & 85 & 291,000 & 19.9 \\
\hline Industrial business & 100 & W & 2,700 & 1 & 2,700 & 97.1 \\
\hline Real estate & W & W & 2,600 & 1 & 2,600 & 52.7 \\
\hline Nonindustrial business & 3,100 & 2 & 0 & 0 & 3,100 & 94 \\
\hline Sport/ recreation club & 5,400 & 4 & 10,600 & 5 & 16,000 & 65.5 \\
\hline Other & 3,300 & 2 & 4,300 & 2 & 7,600 & 46.9 \\
\hline Total noncorporate & 138,900 & 99 & 205,300 & 100 & 344,200 & 17 \\
\hline Total & 139,900 & 100 & 205,800 & 100 & 345,600 & 16.9 \\
\hline SE & 22.7 & & 24.7 & & 16.9 & \\
\hline \multicolumn{7}{|c|}{ (In thousands of acres) } \\
\hline Incorporated: & & & & & & \\
\hline Forest industry & 3,667 & 34 & 0 & 0 & 3,667 & 26.4 \\
\hline Farm & 355 & 3 & 263 & 7 & 618 & 34.5 \\
\hline Real estate & 87 & 1 & 29 & 1 & 117 & 50.7 \\
\hline Sport/ recreation club & 117 & 1 & 0 & 0 & 117 & 50.7 \\
\hline Public utility & 63 & 1 & 0 & 0 & 63 & 100 \\
\hline Other & 297 & 3 & 75 & 2 & 373 & 40.8 \\
\hline Total corporate & 4,587 & 43 & 367 & 10 & 4,954 & 17.9 \\
\hline \multicolumn{7}{|l|}{ Unincorporated: } \\
\hline Forest industry & 146 & 1 & 0 & 0 & 146 & 45.5 \\
\hline Farm & 2,377 & 22 & 868 & 23 & 3,246 & 12 \\
\hline Misc. individual & 2,086 & 19 & 2,001 & 53 & 4,087 & 11.7 \\
\hline Industrial business & 359 & 3 & 29 & 1 & 388 & 84 \\
\hline Real estate & 338 & 3 & 309 & 8 & 647 & 31.6 \\
\hline Nonindustrial business & 87 & 1 & 0 & 0 & 87 & 58.4 \\
\hline Sport/ recreation club & 204 & 2 & 87 & 2 & 292 & 32.7 \\
\hline Other & 512 & 5 & 117 & 3 & 629 & 23.4 \\
\hline Total noncorporate & 6,110 & 57 & 3,412 & 90 & 9,522 & 9.3 \\
\hline Total & 10,697 & 100 & 3,779 & 100 & 14,476 & 0.3 \\
\hline SE & 4.1 & & 11.5 & & 0.3 & \\
\hline
\end{tabular}

W- Fewer than 50 owners or less than 0.5 percent 
รั

要

山

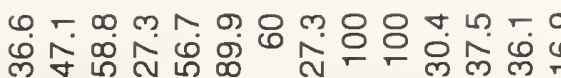

Гம

퓽

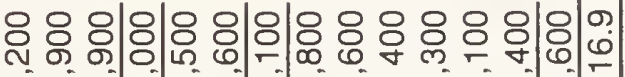

กิ N N

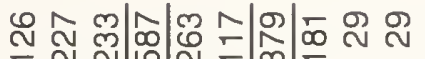

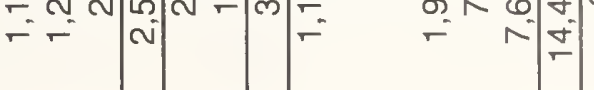

守

○ ู

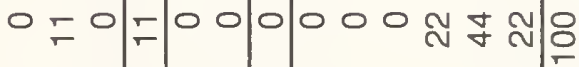

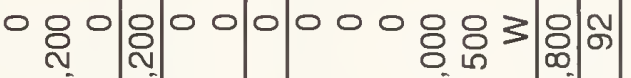

○ R ลี लุ

z

등

党

$\square$

कू

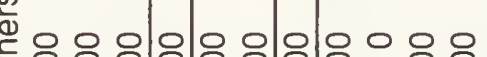

क)

క

d)

क ज N

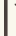

둥

n

एँ

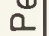

:

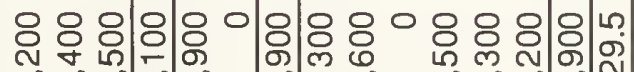

कन न

ल $\forall$ ठ

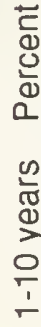

売

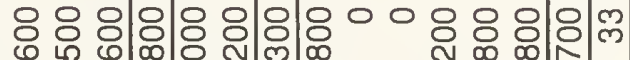

ลั ลิ -

$\omega+\infty$

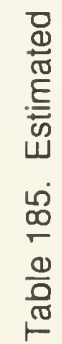

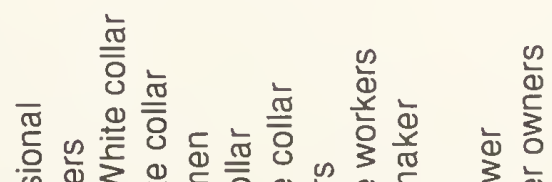

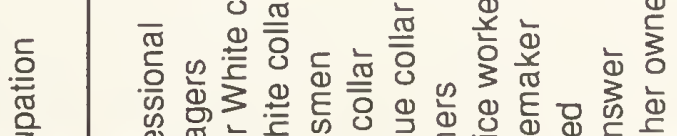

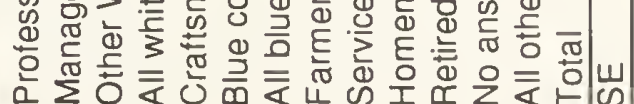

⿹ू巳 $=\infty$ L

广。

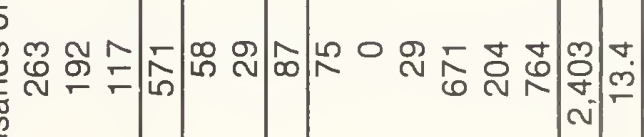

誉

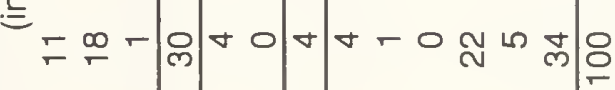

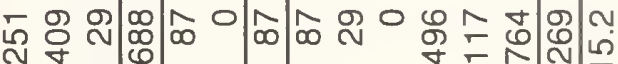

(1)

$0 e^{-4--n-00 n m m ~}$

I

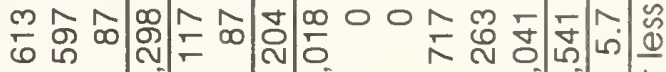

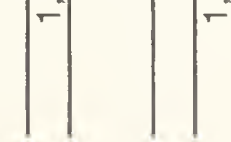

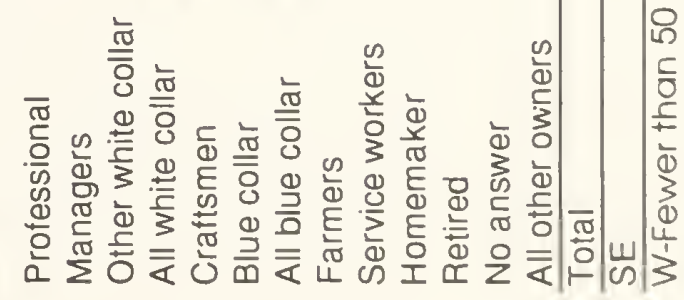


Table 186. Estimated number of ownership units and acres of forest land, by age class and past harvest experience, California, 1993

\begin{tabular}{|c|c|c|c|c|c|c|}
\hline \multirow[t]{2}{*}{ Age } & \multicolumn{4}{|c|}{ Harvest experience } & \multirow{2}{*}{ Total } & \multirow{2}{*}{ SE } \\
\hline & Harvested & Percent & Did not harvest & Percent & & \\
\hline \multicolumn{7}{|c|}{ (In owners) } \\
\hline Under 25 & 0 & 0 & 0 & 0 & 0 & 0 \\
\hline $25-34$ & 3,000 & 2 & 600 & W & 3,600 & 82.7 \\
\hline $35-44$ & 31,600 & 23 & 40,600 & 20 & 72,200 & 36.3 \\
\hline $45-54$ & 15,200 & 11 & 103,300 & 50 & 118,500 & 37.9 \\
\hline $55-64$ & 39,300 & 28 & 20,800 & 10 & 60,100 & 39.1 \\
\hline 65 or over & 38,900 & 28 & 18,800 & 9 & 57,700 & 29.9 \\
\hline No answer & 1,200 & 1 & 900 & W & 2,000 & 61.7 \\
\hline All other owners & 10,600 & 7 & 20,800 & 10 & 31,400 & 36.1 \\
\hline Total & 139,900 & 100 & 205,800 & 100 & 345,600 & 16.9 \\
\hline SE & 22.7 & & 24.7 & & 16.9 & \\
\hline \multicolumn{7}{|c|}{ (In thousands of acres) } \\
\hline Under 25 & 0 & 0 & 0 & 0 & 0 & 0 \\
\hline $25-34$ & 58 & 1 & 29 & 1 & 87 & 58.4 \\
\hline $35-44$ & 613 & 6 & 292 & 8 & 905 & 19.7 \\
\hline $45-54$ & 601 & 6 & 880 & 23 & 1,481 & 16 \\
\hline $55-64$ & 875 & 8 & 630 & 17 & 1,505 & 16.1 \\
\hline 65 or over & 1,832 & 17 & 805 & 21 & 2,637 & 13.2 \\
\hline No answer & 58 & 1 & 175 & 5 & 233 & 36.3 \\
\hline All other owners & 6,659 & 62 & 968 & 26 & 7,627 & 9.1 \\
\hline Total & 10,697 & 100 & 3,779 & 100 & 14,476 & 0.3 \\
\hline SE & 4.1 & & 11.5 & & 0.3 & \\
\hline
\end{tabular}

W-Fewer than 50 owners of less than 0.5 percent 
Table 187. Estimated number of ownership units and acres of forest land, by date of aquisition and form of ownership, California, 1993

Ownership class

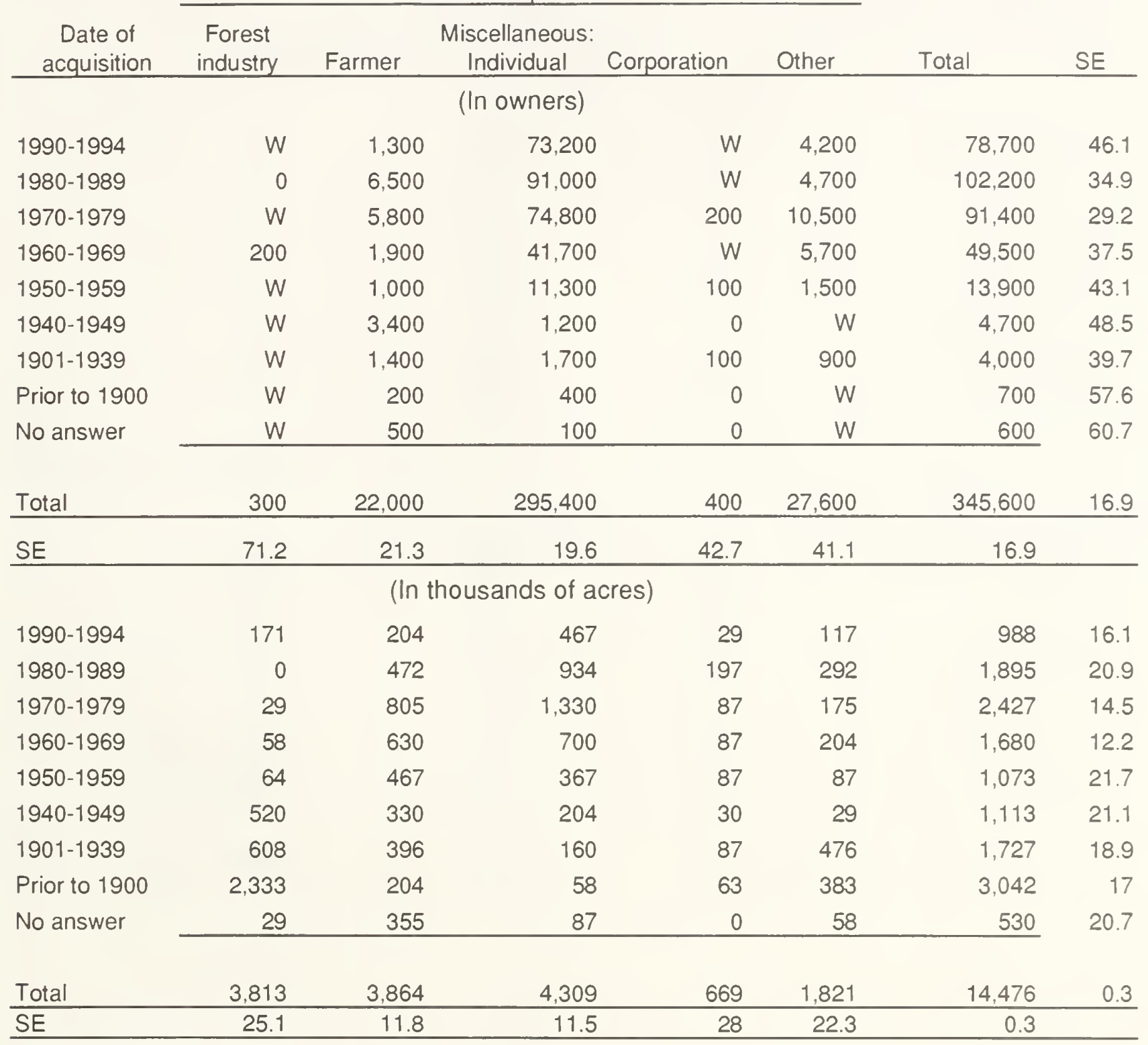

W-fewer than 50 owners or less than 0.5 percent 
Table 188. Estimated number of ownership units and acres of forest land, by distance from tracts, California, 1993

\begin{tabular}{|c|c|c|c|c|}
\hline \multirow[t]{3}{*}{ Distance } & \multicolumn{3}{|c|}{ Tracts } & \multirow{3}{*}{ Total } \\
\hline & \multirow[b]{2}{*}{1 tract } & \multicolumn{2}{|c|}{ More than one tract } & \\
\hline & & Nearest tract & Farthest tract & \\
\hline \multicolumn{5}{|c|}{ (In owners) } \\
\hline Less than 1 mile & 136,500 & 28,900 & 19,200 & \\
\hline 2-5 miles & 2,400 & 4,900 & 3,100 & \\
\hline 6-15 miles & 7,600 & 1,000 & 4,200 & \\
\hline 16-25 miles & 14,700 & 1,300 & 500 & \\
\hline 26-50 rniles & 3,500 & 5,000 & 7,400 & \\
\hline $51-100$ miles & 5,900 & 1,300 & 1,400 & \\
\hline More than 100 miles & 123,900 & 6,800 & 13,400 & \\
\hline No answer & 1,000 & 1,000 & 1,000 & \\
\hline Total & 295,400 & 50,300 & 50,300 & 345,600 \\
\hline \multicolumn{5}{|c|}{ (In thousands of acres) } \\
\hline Less than 1 mile & 1,701 & 2,973 & 700 & \\
\hline 2-5 miles & 204 & 1,506 & 613 & \\
\hline $6-15$ miles & 117 & 2,013 & 542 & \\
\hline $16-25$ miles & 87 & 339 & 309 & \\
\hline 26-50 miles & 409 & 1,104 & 917 & \\
\hline $51-100$ miles & 292 & 338 & 1,504 & \\
\hline More than 100 miles & 1,552 & 705 & 4,394 & \\
\hline No answer & 233 & 902 & 902 & \\
\hline Total & 4,595 & 9,881 & 9,881 & 14,476 \\
\hline
\end{tabular}


Table 189. Estimated number of ownership units and acres of forest land, by primary and secondary reason for owning forest land, California, 1993

\begin{tabular}{|c|c|c|c|c|}
\hline \multirow[t]{2}{*}{ Reason } & \multicolumn{2}{|l|}{ Primary reason } & \multicolumn{2}{|c|}{ Secondary reason } \\
\hline & Number & Percent & Number & Percent \\
\hline & \multicolumn{4}{|c|}{ (In owners) } \\
\hline Land investment & 33,800 & 10 & 5,000 & 2 \\
\hline Recreation & 34,100 & 10 & 28,100 & 8 \\
\hline Timber production & 3,000 & 1 & 3,100 & 1 \\
\hline Farm and domestic use & 7,100 & 2 & 13,600 & 4 \\
\hline Esthetic enjoyment & 95,100 & 28 & 59,700 & 17 \\
\hline Part of farm & 7,400 & 2 & 4,200 & 1 \\
\hline Part of residence & 63,700 & 18 & 27,600 & 8 \\
\hline Estate & 48,800 & 14 & 31,200 & 9 \\
\hline Other & 51,300 & 15 & 7,500 & 2 \\
\hline No secondary reason given & - & - & 164,300 & 48 \\
\hline No answer & 1,300 & $W$ & 1,300 & W \\
\hline \multirow[t]{2}{*}{ Total } & 345,600 & 100 & 345,600 & 100 \\
\hline & \multicolumn{4}{|c|}{ (In thousands of acres) } \\
\hline Land investment & 1,377 & 9 & 2,330 & 16 \\
\hline Recreation & 1,255 & 9 & 1,387 & 10 \\
\hline Timber production & 5,643 & 39 & 629 & 4 \\
\hline Farm and domestic use & 1,030 & 7 & 601 & 4 \\
\hline Esthetic enjoyment & 1,371 & 9 & 1,347 & 9 \\
\hline Part of farm & 1,153 & 8 & 409 & 3 \\
\hline Part of residence & 979 & 7 & 542 & 4 \\
\hline Estate & 571 & 4 & 1,547 & 11 \\
\hline Other & 846 & 6 & 175 & 1 \\
\hline No secondary reason given & - & - & 5,258 & 36 \\
\hline No answer & 251 & $\underline{2}$ & 251 & 2 \\
\hline Total & 14,476 & 100 & 14,476 & 100 \\
\hline
\end{tabular}


Table 190. Estimated number of ownership units and acres of forest land, by primary benefit expected in the next 10 years and past harvest experience. California, 1993

\begin{tabular}{|c|c|c|c|c|c|c|}
\hline \multirow[t]{2}{*}{ Benefits expected } & \multicolumn{4}{|c|}{ Harvest Experience } & \multirow{2}{*}{ Total } & \multirow{2}{*}{ SE } \\
\hline & Harvested & Percent & Did not harvest & Percent & & \\
\hline \multicolumn{7}{|c|}{ (In owners) } \\
\hline Land value increase & 26,300 & 19 & 63,500 & 31 & 89,800 & 40.3 \\
\hline Recreation & 7,400 & 5 & 55,500 & 27 & 62,900 & 51.7 \\
\hline Income from timber & 3,100 & 2 & 1,300 & 1 & 4,400 & 24.7 \\
\hline Farm and domestic us $\epsilon$ & 8,800 & 6 & 7,000 & 3 & 15,800 & 27.3 \\
\hline Esthetic enjoyment & 85,800 & 61 & 62,100 & 30 & 148,000 & 23.2 \\
\hline Firewood & 0 & 0 & 0 & 0 & 0 & 0 \\
\hline Other & 7,800 & 5 & 15,800 & 8 & 23,600 & 43.2 \\
\hline No answer & 700 & 1 & 500 & W & 1,200 & 55.6 \\
\hline Total & 139,900 & 100 & 205,800 & 100 & 345,600 & 16.9 \\
\hline SE & 22.7 & & 24.7 & & 16.9 & \\
\hline \multicolumn{7}{|c|}{ (In thousands of acres) } \\
\hline Land value increase & 688 & 6 & 980 & 26 & 1,668 & 15.4 \\
\hline Recreation & 700 & 7 & 513 & 13 & 1,213 & 17.5 \\
\hline Income from timber & 5,651 & 53 & 263 & 7 & 5,914 & 13.7 \\
\hline Farm and domestic us $\epsilon$ & 1,289 & 12 & 280 & 7 & 1,569 & 15.7 \\
\hline Esthetic enjoyment & 1,583 & 15 & 1,184 & 31 & 2.767 & 15.3 \\
\hline Firewood & 0 & 0 & 0 & 0 & 0 & 0 \\
\hline Other & 400 & 4 & 396 & 10 & 797 & 21.3 \\
\hline No answer & 384 & 3 & 163 & 4 & 547 & 38.2 \\
\hline Total & 10,697 & 100 & 3,779 & 100 & 14.476 & 0.3 \\
\hline SE & 4.1 & & 11.5 & & 0.3 & \\
\hline
\end{tabular}

W-fewer than 50 owners or less than 0.5 percent 


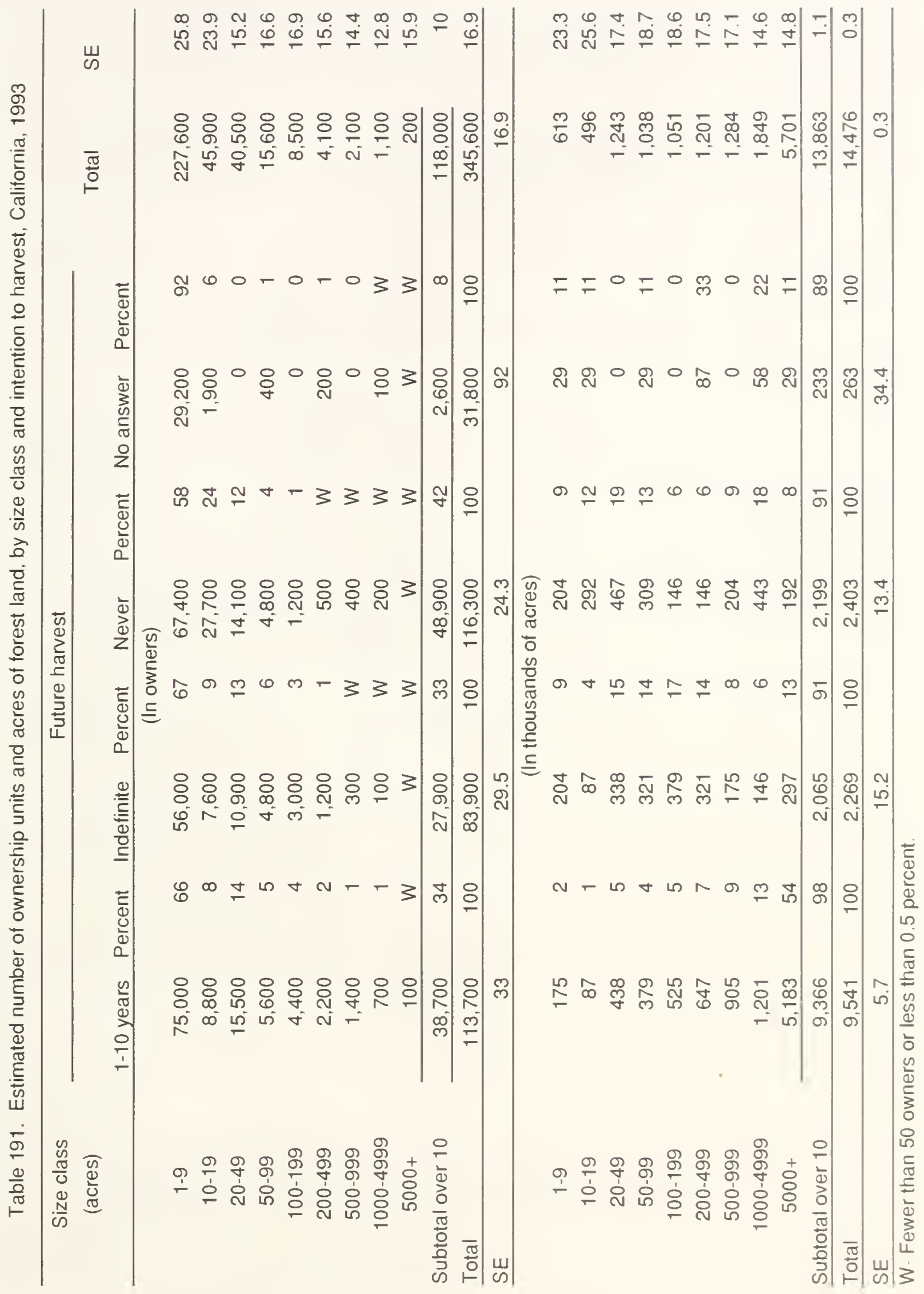




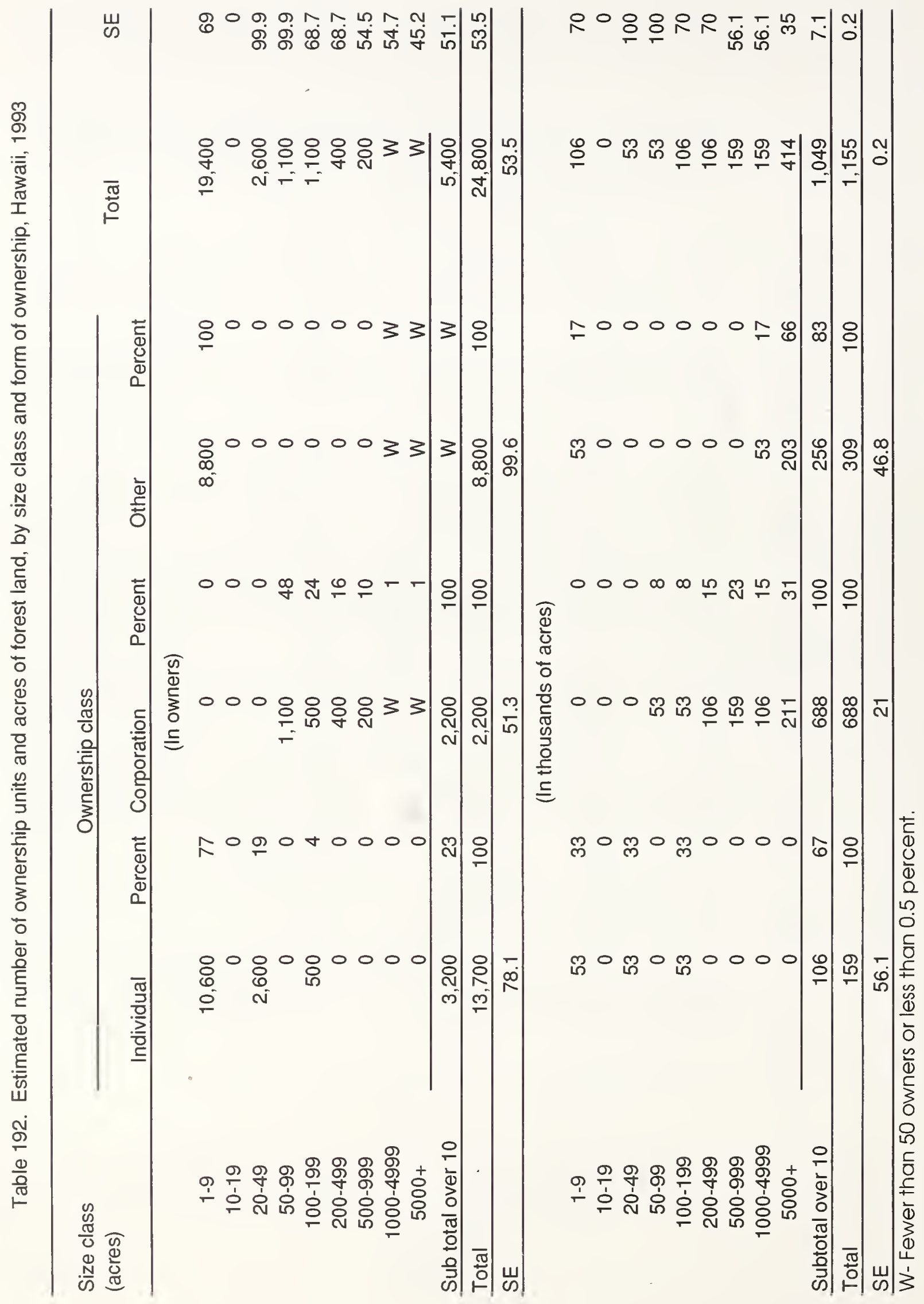


Table 193. Estimated number of ownership units and acres of forest land, by form of ownership and past harvest experience, Hawaii, 1993

\begin{tabular}{|c|c|c|c|c|c|c|}
\hline \multirow{2}{*}{ Form of ownership } & \multicolumn{4}{|c|}{ Harvest experience } & \multirow{2}{*}{ Total } & \multirow{2}{*}{ SE } \\
\hline & Harvested & Percent & Did not harvest & Percent & & \\
\hline \multicolumn{7}{|c|}{ (In owners) } \\
\hline Individual + joint & 0 & 0 & 13,700 & 86 & 13,700 & 12.3 \\
\hline Corporation & W & W & 2,200 & 14 & 2,200 & 27.3 \\
\hline Other & 8,800 & 100 & W & W & 8,800 & 57.4 \\
\hline Total & 8,800 & 100 & 16,000 & 100 & 24,800 & 53.5 \\
\hline SE & 99.6 & & 66.7 & & 53.5 & \\
\hline \multicolumn{7}{|c|}{ (In thousands of acres) } \\
\hline Individual + joint & 0 & 0 & 159 & 20 & 159 & 56.1 \\
\hline Corporation & 106 & 29 & 582 & 73 & 688 & 21 \\
\hline Other & 256 & 71 & 53 & 7 & 309 & 46.8 \\
\hline Total & 361 & 100 & 793 & 100 & 1,155 & 0.2 \\
\hline SE & 40.1 & & 18.3 & & 0.2 & \\
\hline
\end{tabular}

W-Fewer than 50 owners or less than 0.5 percent 
Table 194. Estimated number of ownership units and acres of forest land, by incorporated and unincorporated businesses and past harvest experience, Hawaii, 1993

\begin{tabular}{|c|c|c|c|c|c|c|}
\hline \multirow[t]{2}{*}{ Nature of business } & \multicolumn{4}{|c|}{ Harvest } & \multirow{2}{*}{ Total } & \multirow{2}{*}{ SE } \\
\hline & Harvested & Percent & Did not harvest & Percent & & \\
\hline \multicolumn{7}{|c|}{ (In owners) } \\
\hline Incorporated: & & $W$ & & & & \\
\hline $\begin{array}{l}\text { Farm } \\
\text { Industrial business }\end{array}$ & W & W & 200 & 5 & 800 & $\begin{array}{l}71.9 \\
54.5\end{array}$ \\
\hline & 0 & 0 & 1200 & 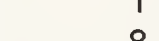 & 200 & 34.5 \\
\hline Other & 0 & 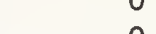 & 1,200 & 8 & 1,200 & 86 \\
\hline Total cornorate & & WI & $\frac{500}{0}$ & & 0 & \\
\hline \multirow{2}{*}{\multicolumn{7}{|c|}{ Unincorporated: }} \\
\hline & & & & & & \\
\hline Farm & W & W & W & W & W & 79 \\
\hline Misc. individual & 0 & 0 & 13,700 & 86 & 13,700 & 78.1 \\
\hline Other & 8,800 & 100 & 0 & 0 & 8,800 & 99.8 \\
\hline Total noncorporate & 8,800 & 100 & 13,800 & 86 & 22,600 & 59.4 \\
\hline Total & 8,800 & 100 & 16,000 & 100 & 24,800 & 53.5 \\
\hline SE & 99.6 & & 66.7 & & 53.5 & \\
\hline \multirow{2}{*}{\multicolumn{7}{|c|}{ (In thousands of acres) }} \\
\hline & & & & & & \\
\hline Farm & 106 & 29 & 317 & 40 & 423 & 30.8 \\
\hline Industrial business & 0 & 0 & 159 & 20 & 159 & 56.1 \\
\hline Real estate & 0 & 0 & 106 & 13 & 106 & 70 \\
\hline Other & 0 & 0 & 0 & 0 & 0 & 0 \\
\hline Total corporate & 106 & 29 & 582 & 73 & 688 & 21 \\
\hline \multicolumn{7}{|l|}{ Unincorporated: } \\
\hline Farm & 53 & 15 & 53 & 7 & 106 & 70 \\
\hline Misc. individual & 0 & 0 & 159 & 20 & 159 & 56.1 \\
\hline Other & 203 & 56 & 0 & 0 & 203 & 69.2 \\
\hline Total noncorporate & 256 & 71 & 211 & 27 & 467 & 31 \\
\hline Total & 361 & 100 & 793 & 100 & 1,155 & 0.2 \\
\hline SE & 40.1 & & 18.3 & & 0.2 & \\
\hline
\end{tabular}

W- Fewer than 50 owners or less than 0.5 percent 


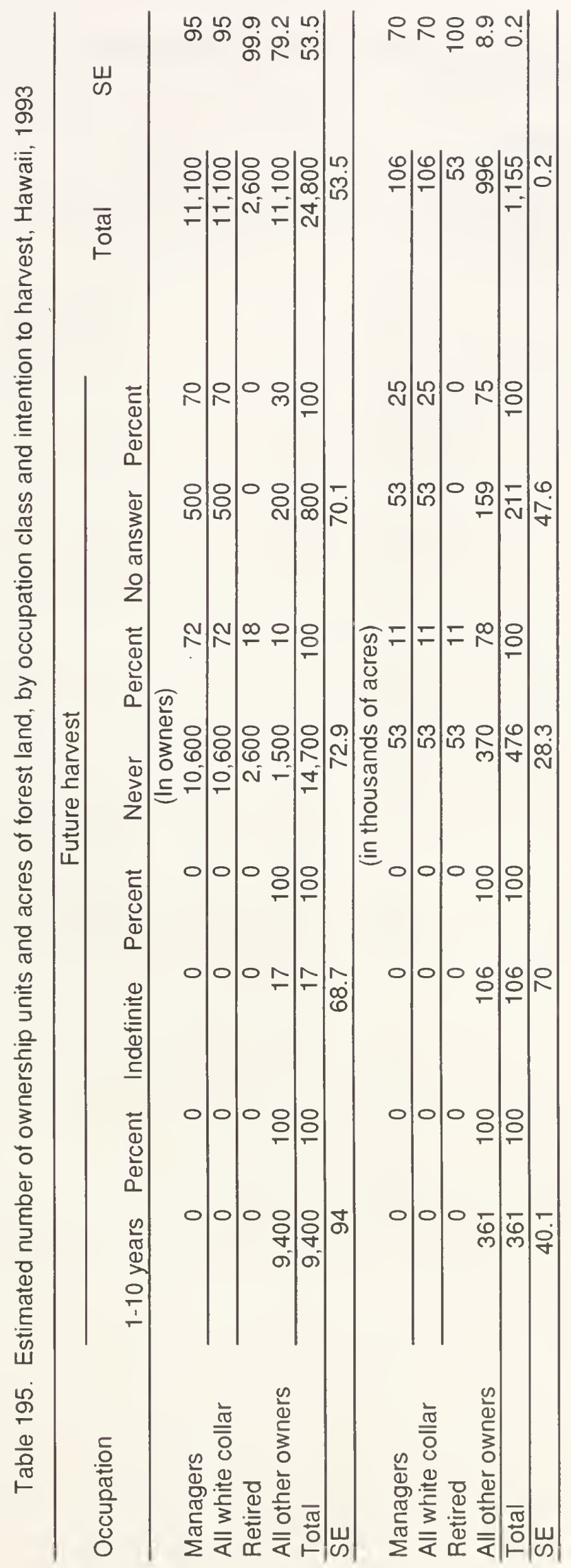


Table 196. Estimated number of ownership units and acres of forest land, by age class and past harvest experience, Hawaii, 1993

\begin{tabular}{|c|c|c|c|c|c|c|}
\hline \multirow[t]{2}{*}{ Age } & \multicolumn{4}{|c|}{ Harvest experience } & \multirow{2}{*}{ Total } & \multirow{2}{*}{ SE } \\
\hline & Harvested & Percent & Did not harvest & Percent & & \\
\hline \multicolumn{7}{|c|}{ (In owners) } \\
\hline $35-44$ & 0 & 0 & 500 & 3 & 500 & 99.9 \\
\hline $45-54$ & 0 & 0 & 2,600 & 17 & 2,600 & 99.9 \\
\hline $55-64$ & 0 & 0 & 0 & 0 & 0 & 0 \\
\hline 65 or over & 0 & 0 & 10,600 & 66 & 10,600 & 99.9 \\
\hline All other owners & 8,800 & 100 & 2,200 & 14 & 11,100 & 79.2 \\
\hline Total & 8,800 & 100 & 16,000 & 100 & 24,800 & 53.5 \\
\hline SE & 99.6 & & 66.7 & & 53.5 & \\
\hline \multicolumn{7}{|c|}{ (In thousands of acres) } \\
\hline $35-44$ & 0 & 0 & 53 & 7 & 53 & 100 \\
\hline $45-54$ & 0 & 0 & 53 & 7 & 53 & 100 \\
\hline $55-64$ & 0 & 0 & 0 & 0 & 0 & 0 \\
\hline 65 or over & 0 & 0 & 53 & 7 & 53 & 100 \\
\hline All other owners & 361 & 100 & 635 & 80 & 996 & 8.9 \\
\hline Total & 361 & 100 & 793 & 100 & 1,155 & 0.2 \\
\hline SE & 40.1 & & 18.3 & & 0.2 & \\
\hline
\end{tabular}


Table 197. Estimated number of ownership units and acres of forest land, by date of aquisition and form of ownership, Hawaii, 1993

Ownership class

\begin{tabular}{|c|c|c|c|c|c|c|c|}
\hline $\begin{array}{c}\text { Date of } \\
\text { acquisition }\end{array}$ & $\begin{array}{c}\text { Forest } \\
\text { industry }\end{array}$ & Farmer & $\begin{array}{l}\text { Miscellaneous: } \\
\text { Individual }\end{array}$ & Corporation & Other & Total & SE \\
\hline \multicolumn{8}{|c|}{ (In owners) } \\
\hline 1990-1994 & 0 & 0 & 0 & 0 & 0 & 0 & 0 \\
\hline 1980-1989 & 0 & 0 & 10,600 & 1,100 & 8,800 & 20,500 & 65.3 \\
\hline $1970-1979$ & 0 & 200 & 500 & 200 & 0 & 900 & 63.7 \\
\hline 1960-1969 & 0 & 500 & 2,600 & 0 & 0 & 3,200 & 84 \\
\hline 1950-1959 & 0 & W & 0 & 0 & 0 & W & 99.9 \\
\hline $1940-1949$ & 0 & 0 & 0 & 0 & 0 & 0 & 0 \\
\hline 1901-1939 & 0 & W & 0 & 0 & 0 & W & 99.9 \\
\hline Prior to 1900 & 0 & 100 & 0 & 0 & W & 100 & 40.1 \\
\hline No answer & 0 & 0 & 0 & 200 & 0 & 200 & 54.5 \\
\hline Total & $\underline{0}$ & 800 & 13,700 & 1,500 & 8,800 & 24,800 & 53.5 \\
\hline SE & 0 & 69.6 & 78.1 & 72.2 & 99.8 & 53.5 & \\
\hline \multicolumn{8}{|c|}{ (In thousands of acres) } \\
\hline 1990-1994 & 0 & 0 & 0 & 0 & 0 & 0 & 0 \\
\hline 1980-1989 & 0 & 0 & 53 & 53 & 53 & 159 & 56.1 \\
\hline $1970-1979$ & 0 & 53 & 53 & 53 & 0 & 159 & 56.1 \\
\hline $1960-1969$ & 0 & 53 & 53 & 0 & 0 & 106 & 70 \\
\hline 1950-1959 & 0 & 53 & 0 & 0 & 0 & 53 & 100 \\
\hline $1940-1949$ & 0 & 0 & 0 & 0 & 0 & 0 & 0 \\
\hline 1901-1939 & 0 & 53 & 0 & 0 & 0 & 53 & 100 \\
\hline Prior to 1900 & 0 & 317 & 0 & 0 & 150 & 467 & 31 \\
\hline No answer & 0 & 0 & 0 & 159 & 0 & 159 & 56.1 \\
\hline Total & 0 & 529 & 159 & 9,756 & 3,716 & 1,155 & 0.2 \\
\hline SE & 0 & 26.2 & 56.1 & 10.2 & 21.1 & 0.2 & \\
\hline
\end{tabular}

W-fewer than 50 owners or less than 0.5 percent 
Table 198. Estimated number of ownership units and acres of forest land, by distance from tracts, Hawaii, 1993

\begin{tabular}{|c|c|c|c|c|}
\hline \multirow[t]{3}{*}{ Distance } & \multicolumn{3}{|c|}{ Tracts } & \multirow{3}{*}{ Total } \\
\hline & \multirow[b]{2}{*}{1 tract } & \multicolumn{2}{|c|}{ More than one tract } & \\
\hline & & Nearest tract & Farthest tract & \\
\hline \multicolumn{5}{|c|}{ (In owners) } \\
\hline Less than 1 mile & 8,800 & 800 & 500 & \\
\hline $2-5$ miles & 10,600 & W & 200 & \\
\hline $6-15$ miles & 0 & 0 & W & \\
\hline $16-25$ miles & 0 & 500 & 600 & \\
\hline 26-50 miles & 0 & 200 & 200 & \\
\hline $51-100$ miles & 0 & 0 & 0 & \\
\hline More than 100 miles & 0 & 0 & W & \\
\hline No answer & 1,300 & 2,600 & 2,600 & \\
\hline Total & 20,700 & 4,100 & 4,100 & 24,800 \\
\hline \multicolumn{5}{|c|}{ (In thousands of acres) } \\
\hline Less than 1 mile & 53 & 317 & 53 & \\
\hline 2-5 miles & 53 & 309 & 53 & \\
\hline 6-15 miles & 0 & 0 & 211 & \\
\hline $16-25$ miles & 0 & 53 & 211 & \\
\hline 26-50 miles & 0 & 106 & 53 & \\
\hline $51-100$ miles & 0 & 0 & 0 & \\
\hline More than 100 miles & 0 & 0 & 203 & \\
\hline No answer & 211 & 53 & 53 & \\
\hline Total & 317 & 838 & 838 & 1,155 \\
\hline
\end{tabular}

W-Fewer than 50 owners or less than 0.5 percent 
Table 199. Estimated number of ownership units and acres of forest land, by primary and secondary reason for owning forest land, Hawaii, 1993

\begin{tabular}{|c|c|c|c|c|}
\hline \multirow[t]{2}{*}{ Reason } & \multicolumn{2}{|c|}{ Primary reason } & \multicolumn{2}{|c|}{ Secondary reason } \\
\hline & Number & Percent & Number & Percent \\
\hline & \multicolumn{4}{|c|}{ (In owners) } \\
\hline Land investment & 700 & 3 & 0 & 0 \\
\hline Recreation & W & W & 0 & 0 \\
\hline Timber production & 0 & 0 & 0 & 0 \\
\hline Farm and domestic use & 500 & 2 & 0 & 0 \\
\hline Esthetic enjoyment & 0 & 0 & 9,000 & 36 \\
\hline Part of farm & 200 & 1 & 0 & 0 \\
\hline Part of residence & 0 & 0 & 0 & 0 \\
\hline Estate & 13,200 & 53 & 0 & 0 \\
\hline Other & 9,900 & 40 & 0 & 0 \\
\hline No secondary reason given & - & - & 15,600 & 63 \\
\hline No answer & 200 & 1 & 200 & 1 \\
\hline \multirow[t]{2}{*}{ Total } & 24,800 & 100 & 24,800 & 100 \\
\hline & \multicolumn{4}{|c|}{ (In thousands of acres) } \\
\hline Land investment & 106 & 9 & 0 & 0 \\
\hline Recreation & 106 & 9 & 0 & 0 \\
\hline Timber production & 0 & 0 & 0 & 0 \\
\hline Farm and domestic use & 53 & 5 & 0 & 0 \\
\hline Esthetic enjoyment & 0 & 0 & 211 & 18 \\
\hline Part of farm & 159 & 14 & 0 & 0 \\
\hline Part of residence & 0 & 0 & 0 & 0 \\
\hline Estate & 106 & 9 & 0 & 0 \\
\hline Other & 467 & 40 & 0 & 0 \\
\hline No secondary reason given & - & - & 785 & 68 \\
\hline No answer & 159 & 14 & 159 & 14 \\
\hline Total & 1,155 & 100 & 1.155 & 100 \\
\hline
\end{tabular}


Table 200. Estimated number of ownership units and acres of forest land, by primary benefit expected in the next 10 years and past harvest experience, Hawaii, 1993

\begin{tabular}{|c|c|c|c|c|c|c|}
\hline \multirow[t]{2}{*}{ Benefits expected } & \multicolumn{4}{|c|}{ Harvest Experience } & \multirow{2}{*}{ Total } & \multirow{2}{*}{ SE } \\
\hline & Harvested & Percent & Did not harvest & Percent & & \\
\hline \multicolumn{7}{|c|}{ (In owners) } \\
\hline Land value increase & 0 & 0 & 14,800 & 93 & 14,800 & 72.4 \\
\hline Recreation & 0 & 0 & 200 & 1 & 200 & 85.3 \\
\hline Income from timber & 0 & 0 & 0 & 0 & 0 & 0 \\
\hline Farm and domestic use & W & W & W & WW & & 79 \\
\hline Esthetic enjoyment & 8,800 & 100 & 500 & 3 & 9,300 & 94.1 \\
\hline Firewood & 0 & 0 & 0 & 0 & 0 & 0 \\
\hline Other & W & W & 200 & 1 & 200 & 88.5 \\
\hline No answer & 0 & 0 & 200 & 1 & 200 & 54.5 \\
\hline Total & 8,800 & 100 & 16,000 & 100 & 24,800 & 53.5 \\
\hline SE & 99.6 & & 66.7 & & 53.5 & \\
\hline \multicolumn{7}{|c|}{ (In thousands of acres) } \\
\hline Land value increase & 0 & 0 & 211 & 27 & 211 & 47.6 \\
\hline Recreation & 0 & 0 & 159 & 20 & 159 & 56.1 \\
\hline Income from timber & 0 & 0 & 0 & 0 & 0 & c \\
\hline Farm and domestic use & 53 & 15 & 53 & 7 & 106 & 70 \\
\hline Esthetic enjoyment & 53 & 15 & 53 & 7 & 106 & 70 \\
\hline Firewood & 0 & 0 & 0 & 0 & 0 & 0 \\
\hline Other & 256 & 70 & 159 & 20 & 414 & 35 \\
\hline No answer & 0 & 0 & 159 & 20 & 159 & 56.1 \\
\hline Total & 361 & 100 & 793 & 100 & 1,155 & 0.2 \\
\hline SE & 40.1 & & 18.3 & & 0.2 & \\
\hline
\end{tabular}

W-fewer than 50 owners or less than 0.5 percent 


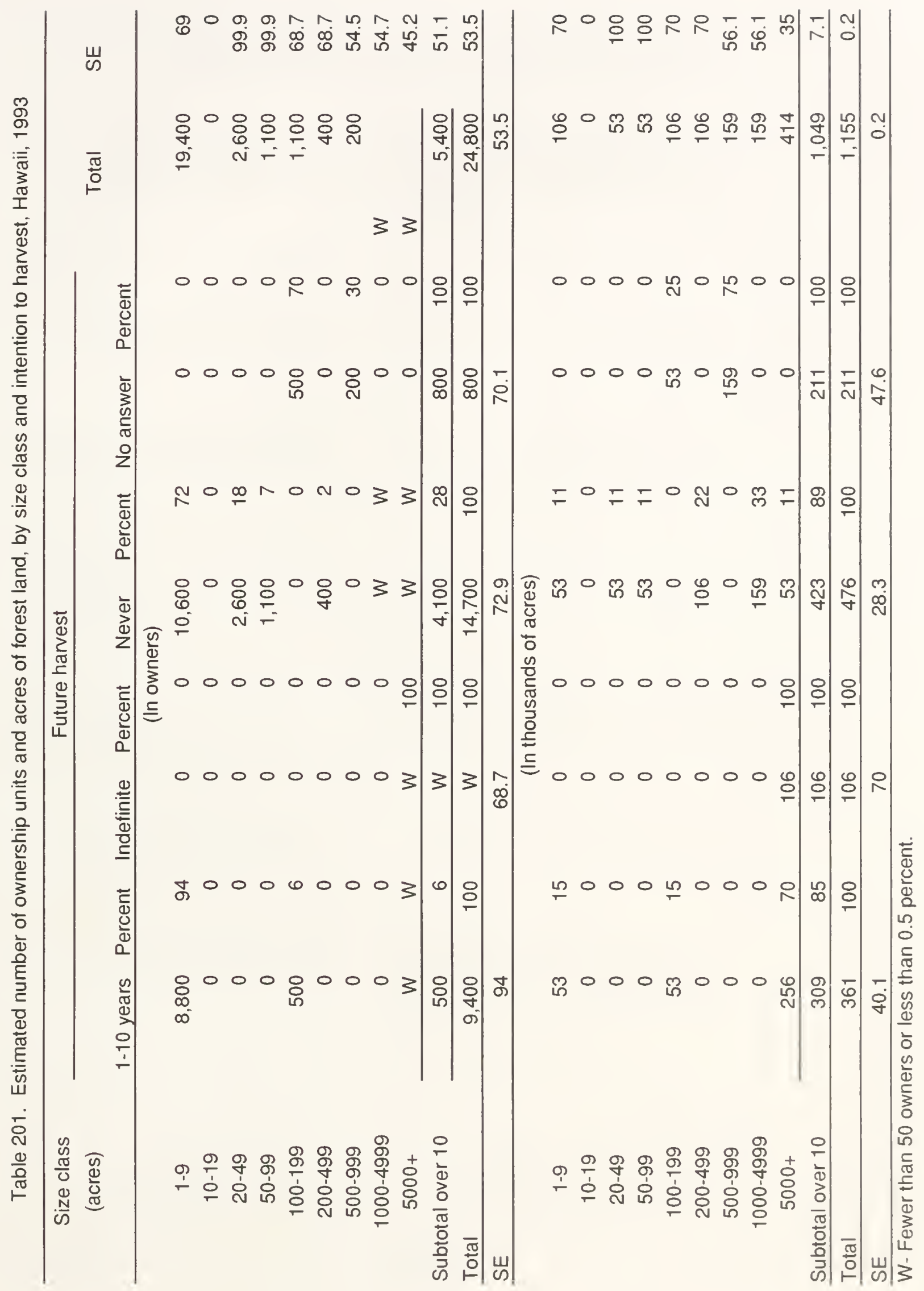




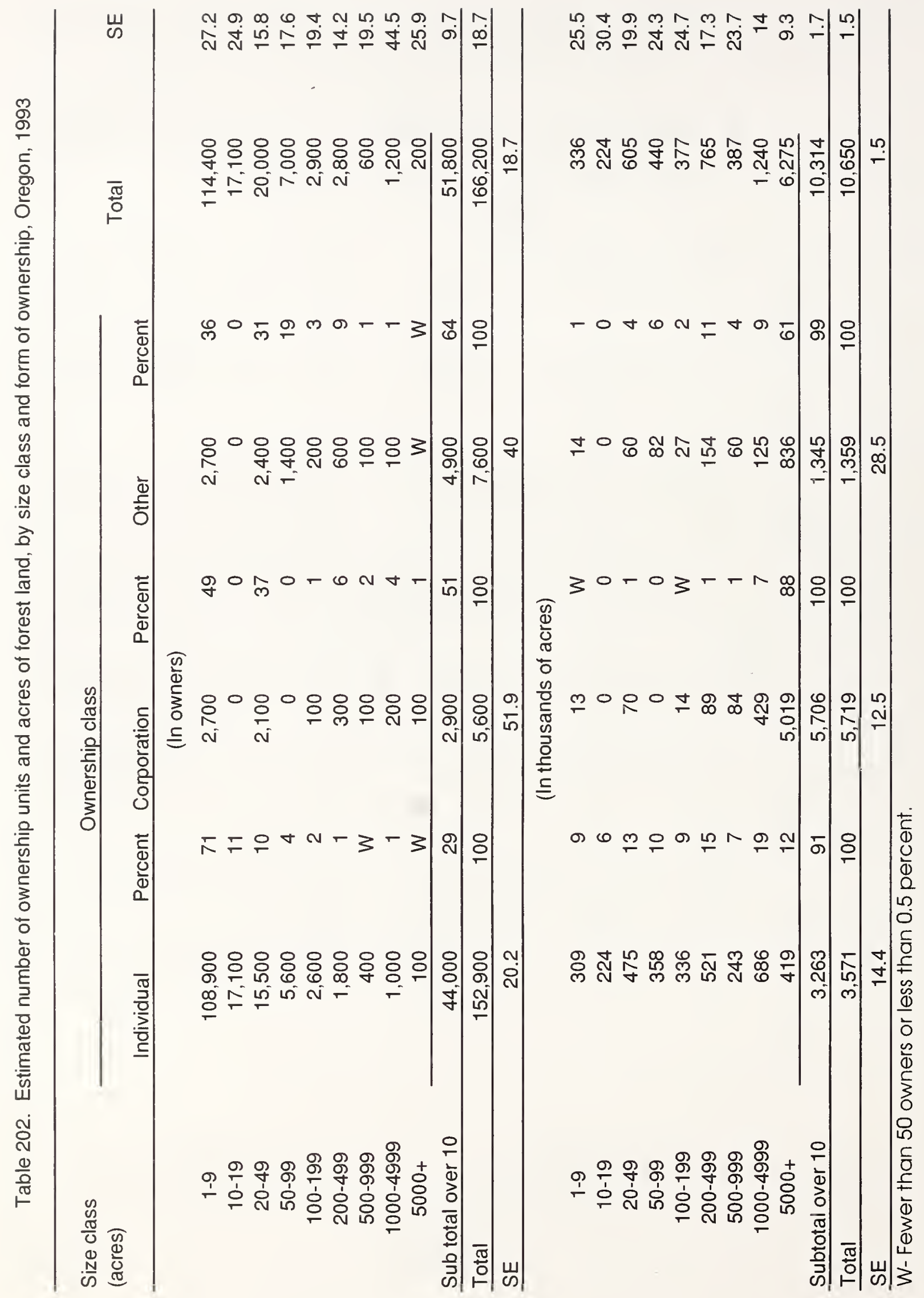


Table 203. Estimated number of ownership units and acres of forest land, by form of ownership and past harvest experience, Oregon, 1993

Form of ownership

Harvest experience

Total

SE

Harvested Percent Did notharvest Percent

(In owners)

\begin{tabular}{|c|c|c|c|c|c|c|}
\hline Individual + joint & 66,300 & 95 & 86,600 & 90 & 152,900 & 20.2 \\
\hline Partnership & 1,600 & 2 & 1,700 & 2 & 3,400 & 33 \\
\hline Corporation & 800 & 1 & 4,900 & 5 & 5,600 & 51.9 \\
\hline Club/association & 200 & W & 0 & 0 & 200 & 99.9 \\
\hline Other & 1,200 & 2 & 2,800 & 3 & 4,000 & 71.1 \\
\hline Total & 70,100 & 100 & 96,000 & 100 & 166,200 & 18.7 \\
\hline SE & 28.8 & & 25.3 & & 18.7 & \\
\hline \multicolumn{7}{|c|}{ (In thousands of acres) } \\
\hline Individual + joint & 2.614 & 28 & 957 & 67 & 3.571 & 14.4 \\
\hline Partnership & 655 & 7 & 244 & 17 & 898 & 26.1 \\
\hline Corporation & 5,532 & 60 & 187 & 13 & 5,719 & 12.5 \\
\hline Club/association & 14 & W & 0 & 0 & 14 & 100 \\
\hline Other & 406 & 4 & 41 & 3 & 447 & 68.2 \\
\hline Total & 9,221 & 100 & 1,429 & 100 & 10,650 & 1.5 \\
\hline SE & 2.7 & & 13.9 & & 1.5 & \\
\hline
\end{tabular}

W-Fewer than 50 owners or less than 0.5 percent 
Table 204. Estimated number of ownership units and acres of forest land, by incorporated and unincorporated businesses and past harvest experience, Oregon, 1993

\begin{tabular}{|c|c|c|c|c|c|c|}
\hline \multirow[t]{2}{*}{ Nature of business } & \multicolumn{4}{|c|}{ Harvest } & \multirow{2}{*}{ Total } & \multirow{2}{*}{ SE } \\
\hline & Harvested & Percent & Did not harvest & Percent & & \\
\hline \multicolumn{7}{|c|}{ (In owners) } \\
\hline \multicolumn{7}{|l|}{ Incorporated: } \\
\hline Forest industry & 100 & W & 0 & 0 & 100 & 31.6 \\
\hline Farm & 500 & 1 & 2,100 & 2 & 2,600 & 40.7 \\
\hline Real estate & 200 & W & 2,700 & 3 & 2,900 & 94.6 \\
\hline Public utility & W & W & 0 & 0 & W & 70.5 \\
\hline Other & W & W & W & W & W & 50.9 \\
\hline Total corporate & 800 & 1 & 4,900 & 5 & 5,600 & 51.9 \\
\hline \multicolumn{7}{|l|}{ Unincorporated: } \\
\hline Forest industry & W & W & 0 & 0 & W & 58.3 \\
\hline Farm & 15,700 & 22 & 7,100 & 7 & 22,700 & 21.1 \\
\hline Misc. individual & 51,800 & 74 & 77,000 & 80 & 128,800 & 23.9 \\
\hline Industrial business & 200 & $W$ & W & W & 200 & 98.1 \\
\hline Real estate & 100 & W & 300 & W & 400 & 80.6 \\
\hline Nonindustrial business & 400 & 1 & 3,300 & 3 & 3,700 & 75.8 \\
\hline Sport/ recreation club & 200 & W & 0 & 0 & 200 & 99.9 \\
\hline Other & 1,000 & 1 & 3,400 & 3 & 4,400 & 53.1 \\
\hline Total noncorporate & 69,400 & 99 & 91,100 & 95 & 160,500 & 19.3 \\
\hline Total & 70,100 & 100 & 96,000 & 100 & 166,200 & 18.7 \\
\hline SE & 28.8 & & 25.3 & & 18.7 & \\
\hline \multirow{2}{*}{\multicolumn{7}{|c|}{ (In thousands of acres) }} \\
\hline & & & & & & \\
\hline Forest industry & 4,850 & 53 & 0 & 0 & 4,850 & 16.1 \\
\hline Farm & 439 & 5 & 127 & 9 & 566 & 16.9 \\
\hline Real estate & 101 & 1 & 14 & 1 & 114 & 59.9 \\
\hline Public utility & 27 & $W$ & 0 & 0 & 27 & 73.3 \\
\hline Other & 115 & 1 & 46 & 3 & 161 & 66.9 \\
\hline Total corporate & 5,532 & 60 & 187 & 13 & 5,719 & 12.5 \\
\hline \multicolumn{7}{|l|}{ Unincorporated: } \\
\hline Forest industry & 433 & 5 & 0 & 0 & 433 & 49.1 \\
\hline Farm & 1,743 & 19 & 487 & 34 & 2,230 & 12 \\
\hline Misc. individual & 945 & 10 & 615 & 43 & 1,560 & 18.6 \\
\hline Industrial business & 13 & $W$ & 14 & 1 & 27 & 73.3 \\
\hline Real estate & 93 & 1 & 19 & 1 & 111 & 39.2 \\
\hline Nonindustrial business & 27 & W & 33 & 2 & 60 & 52.2 \\
\hline Sport/ recreation club & 14 & W & 0 & 0 & 14 & 100 \\
\hline Other & 420 & 5 & 73 & 5 & 493 & 65.5 \\
\hline Total noncorporate & 3,689 & 40 & 1,241 & 87 & 4,930 & 14.5 \\
\hline Total & 9,221 & 100 & 1,429 & 100 & 10,650 & 1.5 \\
\hline $\mathrm{SE}$ & 2.7 & & 13.9 & & 1.5 & \\
\hline
\end{tabular}

W- Fewer than 50 owners or less than 0.5 percent 


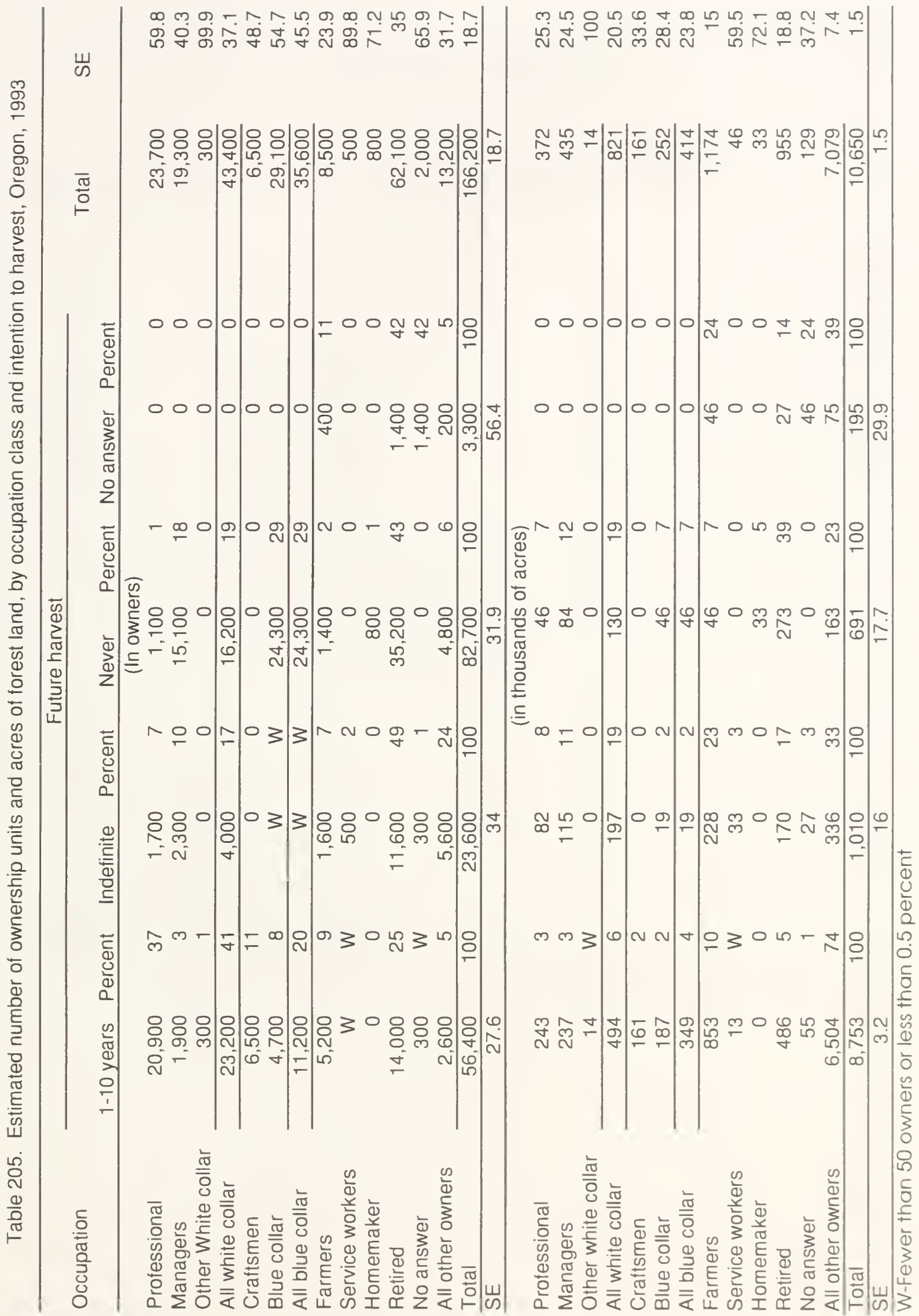


Table 206. Estimated number of ownership units and acres of forest land, by age class and past harvest experience, Oregon, 1993

\begin{tabular}{|c|c|c|c|c|c|c|}
\hline \multirow[t]{2}{*}{ Age } & \multicolumn{4}{|c|}{ Harvest experience } & \multirow{2}{*}{ Total } & \multirow{2}{*}{ SE } \\
\hline & Harvested & Percent & Did not harvest & Percent & & \\
\hline \multicolumn{7}{|c|}{ (In owners) } \\
\hline Under 25 & 0 & 0 & 0 & 0 & 0 & 0 \\
\hline $25-34$ & 1,700 & 2 & 500 & W & 2,200 & 59.3 \\
\hline $35-44$ & 36,900 & 53 & 9,000 & 9 & 45,900 & 44.5 \\
\hline $45-54$ & 5,600 & 8 & 12,700 & 13 & 18,300 & 29.9 \\
\hline $55-64$ & 9,300 & 13 & 29,100 & 30 & 38,400 & 31.3 \\
\hline 65 or over & 12,000 & 17 & 34,000 & 35 & 46,000 & 43.8 \\
\hline No answer & 700 & 1 & 1,400 & 1 & 2,100 & 65 \\
\hline All other owners & 3,900 & 5 & 9,400 & 10 & 13,200 & 31.7 \\
\hline Total & 70,100 & 100 & 96,000 & 100 & 166,200 & 18.7 \\
\hline SE & 28.8 & & 25.3 & & 18.7 & \\
\hline \multicolumn{7}{|c|}{ (In thousands of acres) } \\
\hline Under 25 & 0 & 0 & 0 & 0 & 0 & 0 \\
\hline $25-34$ & 41 & W & 19 & 1 & 60 & 52.2 \\
\hline $35-44$ & 281 & 3 & 153 & 11 & 434 & 22.7 \\
\hline $45-54$ & 466 & 5 & 226 & 16 & 693 & 19.3 \\
\hline $55-64$ & 654 & 7 & 207 & 15 & 862 & 18.9 \\
\hline 65 or over & 1,130 & 12 & 319 & 22 & 1,449 & 16.5 \\
\hline No answer & 41 & W & 33 & 2 & 74 & 47.3 \\
\hline All other owners & 6,607 & 72 & 472 & 33 & 7,070 & 7.4 \\
\hline Total & 9,221 & 100 & 1,429 & 100 & 10,650 & 1.5 \\
\hline SE & 2.7 & & 13.9 & & 1.5 & \\
\hline
\end{tabular}

W-Fewer than 50 owners of less than 0.5 percent 
Table 207. Estimated number of ownership units and acres of forest land, by date of aquisition and form of ownership, Oregon, 1993

\begin{tabular}{|c|c|c|c|c|c|c|c|}
\hline \multirow[b]{2}{*}{$\begin{array}{c}\text { Date of } \\
\text { acquisition }\end{array}$} & \multicolumn{5}{|c|}{ Ownership class } & \multirow[b]{2}{*}{ Total } & \multirow[b]{2}{*}{ SE } \\
\hline & $\begin{array}{l}\text { Forest } \\
\text { industry }\end{array}$ & Farmer & $\begin{array}{c}\text { Miscellaneous: } \\
\text { Individual }\end{array}$ & Corporation & Other & & \\
\hline \multicolumn{8}{|c|}{ (In owners) } \\
\hline 1990-1994 & 0 & 2,900 & 31,700 & 2,700 & 2,900 & 40,300 & 28.9 \\
\hline 1980-1989 & W & 5,300 & 57,600 & 100 & 400 & 63,400 & 34.5 \\
\hline $1970-1979$ & $w$ & 6,600 & 13,000 & 100 & 800 & 20,500 & 23.9 \\
\hline $1960-1969$ & W & 3,200 & 4,500 & 0 & 300 & 8,000 & 46.1 \\
\hline $1950-1959$ & W & 3,100 & 2,700 & W & 900 & 6,700 & 32 \\
\hline $1940-1949$ & W & 1,200 & 3,300 & W & 0 & 4,500 & 40.3 \\
\hline 1901-1939 & W & 1,200 & 100 & W & 300 & 1,700 & 40.1 \\
\hline Prior to 1900 & W & W & 0 & 0 & $W$ & W & 58.5 \\
\hline No answer & W & 1,700 & 19,200 & W & W & 21,000 & 89.7 \\
\hline Total & 200 & 25,300 & 132,100 & 2,900 & 5,700 & 166,200 & 18.7 \\
\hline SE & 28.4 & 19.2 & 23.3 & 93.8 & 51.7 & 18.7 & \\
\hline \multicolumn{8}{|c|}{ (In thousands of acres) } \\
\hline 1990-1994 & 0 & 195 & 286 & 33 & 27 & 542 & 19.9 \\
\hline 1980-1989 & 77 & 625 & 418 & 129 & 70 & 1,319 & 16.1 \\
\hline 1970-1979 & 78 & 606 & 427 & 14 & 41 & 1,166 & 15.9 \\
\hline 1960-1969 & 234 & 295 & 172 & 0 & 27 & 729 & 29.7 \\
\hline 1950-1959 & 867 & 494 & 139 & 14 & 41 & 1,555 & 35.1 \\
\hline 1940-1949 & 675 & 185 & 110 & 14 & 0 & 984 & 35.2 \\
\hline 1901-1939 & 1,358 & 204 & 33 & 87 & 82 & 1,764 & 31.4 \\
\hline Prior to 1900 & 1,958 & 33 & 0 & 0 & 305 & 2,295 & 46 \\
\hline No answer & 36 & 160 & 60 & 14 & 27 & 296 & 25.2 \\
\hline Total & 5,283 & 2,797 & 1,645 & 303 & 622 & 10,650 & 1.5 \\
\hline SE & 13.4 & 10.4 & 18 & 44.2 & 50.2 & 1.5 & \\
\hline
\end{tabular}

W-fewer than 50 owners or less than 0.5 percent 
Table 208. Estimated number of ownership units and acres of forest land, by distance from tracts, Oregon, 1993

\begin{tabular}{|c|c|c|c|c|}
\hline \multirow[t]{3}{*}{ Distance } & \multicolumn{3}{|c|}{ Tracts } & \multirow{3}{*}{ Total } \\
\hline & \multirow[b]{2}{*}{1 tract } & \multicolumn{2}{|c|}{ More than one tract } & \\
\hline & & Nearest tract & Farthest tract & \\
\hline \multicolumn{5}{|c|}{ (In owners) } \\
\hline Less than 1 mile & 94,700 & 23,300 & 15,700 & \\
\hline 2-5 miles & 800 & 600 & 1,700 & \\
\hline 6-15 miles & 4,300 & 2,100 & 3,300 & \\
\hline 16-25 miles & 3,200 & 500 & 700 & \\
\hline $26-50$ miles & 1,900 & 300 & 700 & \\
\hline $51-100$ miles & 600 & 400 & 1,300 & \\
\hline More than 100 miles & 23,000 & 1,900 & 5,700 & \\
\hline No answer & 8,500 & 100 & 100 & \\
\hline Total & 136,900 & 29,200 & 29,200 & 166,200 \\
\hline \multicolumn{5}{|c|}{ (In thousands of acres) } \\
\hline Less than 1 mile & 1,001 & 3,563 & 382 & \\
\hline $2-5$ miles & 117 & 1,537 & 343 & \\
\hline $6-15$ miles & 161 & 1,627 & 473 & \\
\hline $16-25$ miles & 98 & 361 & 213 & \\
\hline $26-50$ miles & 134 & 151 & 567 & \\
\hline $51-100$ miles & 160 & 115 & 1,729 & \\
\hline More than 100 miles & 314 & 427 & 4,089 & \\
\hline No answer & 228 & 655 & 655 & \\
\hline Total & 2,212 & 8,437 & 8,437 & 10,650 \\
\hline
\end{tabular}


Table 209. Estimated number of ownership units and acres of forest land, by primary and secondary reason for owning forest land, Oregon, 1993

\begin{tabular}{|c|c|c|c|c|}
\hline \multirow[t]{2}{*}{ Reason } & \multicolumn{2}{|c|}{ Primary reason } & \multicolumn{2}{|c|}{ Secondary reason } \\
\hline & Number & Percent & Number & Percent \\
\hline & \multicolumn{4}{|c|}{ (In owners) } \\
\hline Land investment & 29,100 & 18 & 1,300 & 1 \\
\hline Recreation & 5,700 & 3 & 7,700 & 5 \\
\hline Timber production & 7,200 & 4 & 5,700 & 3 \\
\hline Farm and domestic use & 6,900 & 4 & 24,400 & 15 \\
\hline Esthetic enjoyment & 28,700 & 17 & 15,600 & 9 \\
\hline Part of farm & 10,200 & 6 & 1,200 & 1 \\
\hline Part of residence & 61,500 & 37 & 19,600 & 12 \\
\hline Estate & 4,200 & 3 & 45,400 & 27 \\
\hline Other & 11,300 & 7 & 1,300 & 1 \\
\hline No secondary reason given & - & - & 42,700 & 26 \\
\hline No answer & 1,300 & 1 & 1,300 & 1 \\
\hline \multirow[t]{2}{*}{ Total } & 166,200 & 100 & 644,600 & 100 \\
\hline & \multicolumn{4}{|c|}{ (In thousands of acres) } \\
\hline Land investment & 655 & 6 & 1,017 & 10 \\
\hline Recreation & 321 & 3 & 304 & 3 \\
\hline Timber production & 6,355 & 60 & 897 & 8 \\
\hline Farm and domestic use & 421 & 4 & 631 & 6 \\
\hline Esthetic enjoyment & 451 & 4 & 401 & 4 \\
\hline Part of farm & 868 & 8 & 305 & 3 \\
\hline Part of residence & 439 & 4 & 300 & 3 \\
\hline Estate & 298 & 3 & 728 & 7 \\
\hline Other & 687 & 7 & 869 & 8 \\
\hline No secondary reason given & - & - & 5,043 & 47 \\
\hline No answer & 154 & 1 & 154 & 1 \\
\hline Total & 10,650 & 100 & 10,650 & 100 \\
\hline
\end{tabular}


Table 210. Estimated number of ownership units and acres of forest land, by primary benefit expected in the next 10 years and past harvest experience, Oregon, 1993

\begin{tabular}{|c|c|c|c|c|c|c|}
\hline \multirow[t]{2}{*}{ Benefits expected } & \multicolumn{4}{|c|}{ Harvest Experience } & \multirow{2}{*}{ Total } & \multirow{2}{*}{ SE } \\
\hline & Harvested & Percent & Did not harvest & Percent & & \\
\hline \multicolumn{7}{|c|}{ (In owners) } \\
\hline Land value increase & 20,700 & 29 & 16,500 & 17 & 37,200 & 42.6 \\
\hline Recreation & 1,200 & 2 & 2,900 & 3 & 4,100 & 41.7 \\
\hline Income from timber & 3,300 & $s$ & 4,800 & 5 & 8,100 & 43.4 \\
\hline Farm and domestic us $\epsilon$ & 24,900 & $3 t$ & 10,600 & 11 & 35,400 & 44.9 \\
\hline Esthetic enjoyment & 14,200 & 20 & 42,400 & 44 & 56,600 & 36.6 \\
\hline Firewood & 600 & 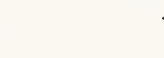 & 500 & W & 1,100 & 58 \\
\hline Other & 3,700 & $s$ & 7,200 & 7 & 10,900 & 43 \\
\hline No answer & 1,500 & 2 & 11,200 & 12 & 12,700 & 52.9 \\
\hline Total & 70,100 & 100 & 96,000 & 100 & 166,200 & 18.7 \\
\hline SE & 28.8 & & 25.3 & & 18.7 & \\
\hline \multicolumn{7}{|c|}{ (In thousands of acres) } \\
\hline Land value increase & 610 & $i$ & 307 & 21 & 917 & 16.4 \\
\hline Recreation & 185 & 2 & 144 & 10 & 329 & 24 \\
\hline Income from timber & 6,467 & 70 & 180 & 13 & 6.647 & 8.1 \\
\hline Farm and domestic use & 666 & 7 & 122 & 9 & 788 & 17.6 \\
\hline Esthetic enjoyment & 526 & $c$ & 355 & 25 & 881 & 18.3 \\
\hline Firewood & 84 & s & 14 & 1 & 98 & 41.9 \\
\hline Other & 528 & 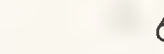 & 158 & 11 & 686 & 45.5 \\
\hline No answer & 154 & 2 & 149 & 10 & 304 & 23.8 \\
\hline Total & 9,221 & 100 & 1,429 & 100 & 10,650 & 1.5 \\
\hline SE & 2.7 & & 13.9 & & 1.5 & \\
\hline
\end{tabular}

W-fewer than 50 owners or less than 0.5 percent 


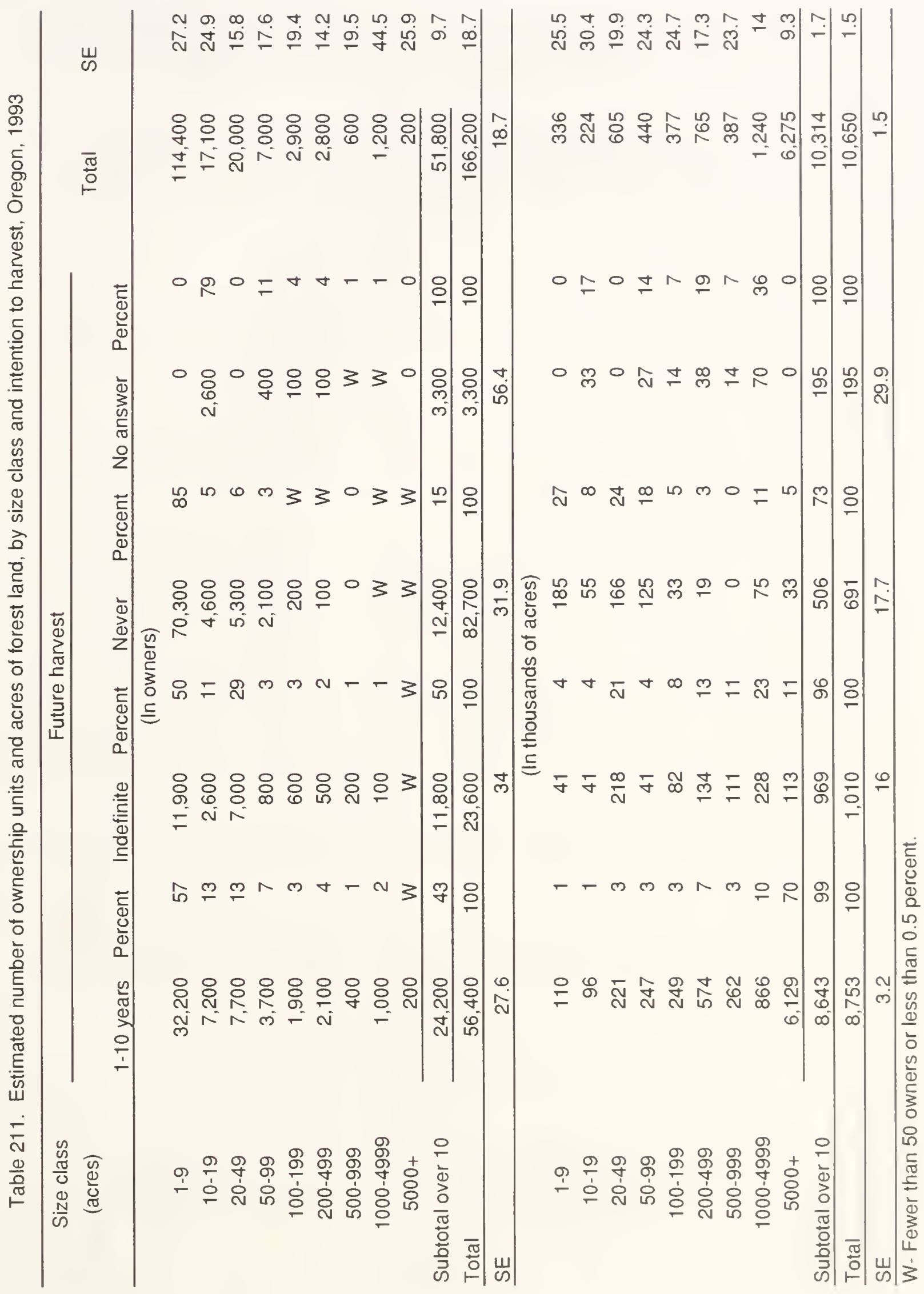




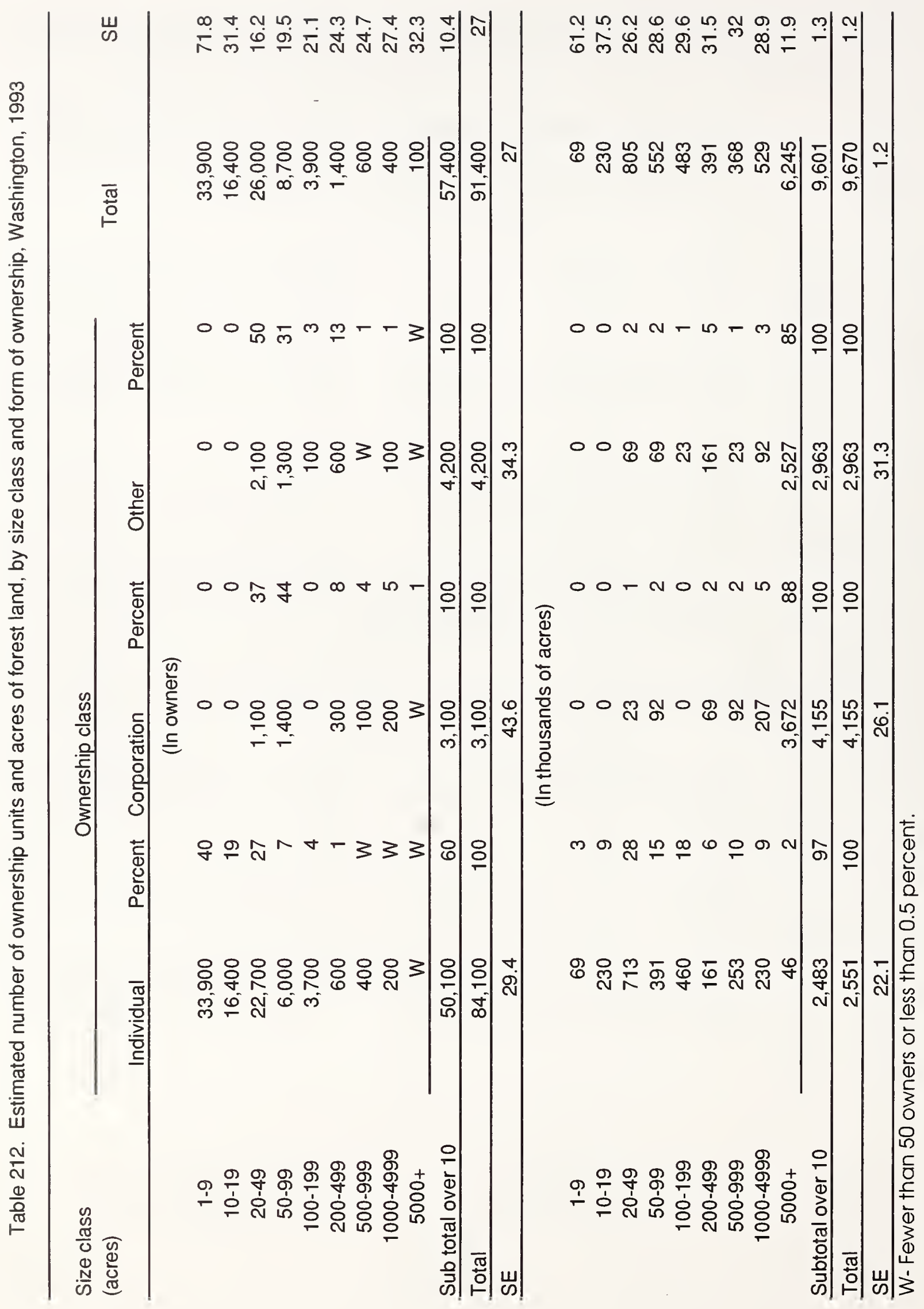


Table 213. Estimated number of ownership units and acres of forest land, by form of ownership and past harvest experience, Washington, 1993

\begin{tabular}{|c|c|c|c|c|c|c|}
\hline \multirow[t]{2}{*}{ Form of ownership } & \multicolumn{4}{|c|}{ Harvest experience } & \multirow{2}{*}{ Total } & \multirow{2}{*}{ SE } \\
\hline & Harvested & Percent & Did not harvest & Percent & & \\
\hline \multicolumn{7}{|c|}{ (In owners) } \\
\hline Individual + joint & 58,800 & 92 & 25,300 & 92 & 84,100 & 29.4 \\
\hline Partnership & 2.900 & 4 & 600 & 2 & 3,500 & 39.7 \\
\hline Corporation & 1,600 & 2 & 1,500 & 5 & 3.100 & 43.6 \\
\hline Club/association & W & $W$ & 0 & 0 & W & 100 \\
\hline Other & 700 & 1 & 0 & 0 & 700 & 66.8 \\
\hline Total & 64,000 & 100 & 27,400 & 100 & 91,400 & 27 \\
\hline SE & 36.5 & & 33.3 & & 27 & \\
\hline \multicolumn{7}{|c|}{ (In thousands of acres) } \\
\hline Individual + joint & 2,046 & 23 & 506 & 85 & 2.551 & 22.1 \\
\hline Partnership & 1,324 & 15 & 23 & 4 & 1,347 & 37.5 \\
\hline Corporation & 4,086 & 45 & 69 & 11 & 4.155 & 26.1 \\
\hline Club/association & 23 & W & 0 & 0 & 23 & 100 \\
\hline Other & 1,593 & 17 & 0 & 0 & 1,593 & 54.9 \\
\hline Total & 9,072 & 100 & 598 & 100 & 9,670 & 1.2 \\
\hline SE & 2.2 & & 28 & & 1.2 & \\
\hline
\end{tabular}

W-Fewer than 50 owners or less than 0.5 percent 
Table 214. Estimated number of ownership units and acres of forest land, by incorporated and unincorporated businesses and past harvest experience, Washington, 1993

\begin{tabular}{|c|c|c|c|c|c|c|}
\hline \multirow[t]{2}{*}{ Nature of business } & \multicolumn{4}{|c|}{ Harvest } & \multirow{2}{*}{ Total } & \multirow{2}{*}{ SE } \\
\hline & Harvested & Percent & Did not harvest & Percent & & \\
\hline \multicolumn{7}{|c|}{ (In owners) } \\
\hline \multicolumn{7}{|l|}{ Incorporated: } \\
\hline Forest industry & 500 & 1 & 0 & 0 & 500 & 61.1 \\
\hline Farm & 100 & W & 1,100 & 4 & 1,300 & 90 \\
\hline Industrial business & W & W & 300 & 1 & 400 & 88.1 \\
\hline Real estate & W & W & W & W & W & 85.9 \\
\hline Sport/ recreation club & 500 & 1 & 0 & 0 & 500 & 100 \\
\hline Public utility & W & W & 0 & 0 & W & 100 \\
\hline Other & 400 & 1 & 0 & 0 & 400 & 74.3 \\
\hline Total corporate & 1,600 & 3 & 1,500 & 5 & 3,100 & 43.6 \\
\hline \multicolumn{7}{|l|}{ Unincorporated: } \\
\hline Forest industry & W & W & 0 & 0 & W & 50.1 \\
\hline Farm & 35,700 & 56 & 13,700 & 50 & 49,500 & 49.4 \\
\hline Misc. individual & 21,100 & 33 & 11,200 & 41 & 32,300 & 16.5 \\
\hline Industrial business & W & W & 400 & 1 & 400 & 98.8 \\
\hline Real estate & 2,100 & 3 & 0 & 0 & 2,100 & 90.7 \\
\hline Nonindustrial business & 1,500 & 2 & 0 & 0 & 1,500 & 78.9 \\
\hline Sport/ recreation club & 800 & 1 & 0 & 0 & 800 & 96.4 \\
\hline Other & 1,100 & 2 & 600 & 2 & 1,600 & 47.5 \\
\hline Total noncorporate & 62,400 & 97 & 25,900 & 95 & 88,300 & 28 \\
\hline Total & 64,000 & 100 & 27,400 & 100 & 91,400 & 27 \\
\hline SE & 36.5 & & 33.3 & & 27 & \\
\hline \multicolumn{7}{|c|}{ (In thousands of acres) } \\
\hline Incorporated: & & & & & & \\
\hline Forest industry & 3,520 & 39 & 0 & 0 & 3,520 & 32.6 \\
\hline Farm & 115 & 1 & 23 & 4 & 138 & 45.5 \\
\hline Industrial business & 23 & W & 23 & 4 & 46 & 73.7 \\
\hline Real estate & 23 & W & 23 & 4 & 46 & 73.7 \\
\hline Sport/ recreation club & 23 & W & 0 & 0 & 23 & 100 \\
\hline Public utility & 23 & W & 0 & 0 & 23 & 100 \\
\hline Other & 359 & 4 & 0 & 0 & 359 & 75.8 \\
\hline Total corporate & 4,086 & 45 & 69 & 11 & 4,155 & 26.1 \\
\hline \multicolumn{7}{|l|}{ Unincorporated: } \\
\hline Forest industry & 1,774 & 19 & 0 & 0 & 1,774 & 46.2 \\
\hline Farm & 1,103 & 12 & 138 & 23 & 1,241 & 24.2 \\
\hline Misc. individual & 919 & 10 & 345 & 58 & 1,264 & 24.1 \\
\hline Industrial business & 23 & W & 23 & 4 & 46 & 73.7 \\
\hline Real estate & 105 & 1 & 0 & 0 & 105 & 54.9 \\
\hline Nonindustrial business & 46 & 1 & 0 & 0 & 46 & 73.7 \\
\hline Sport/ recreation club & 46 & 1 & 0 & 0 & 46 & 73.7 \\
\hline Other & 970 & 11 & 23 & 4 & 993 & 58 \\
\hline Total noncorporate & 4,986 & 55 & 529 & 89 & 5,515 & 19.7 \\
\hline Total & 9,072 & 100 & 598 & 100 & 9,670 & 1.2 \\
\hline SE & 2.2 & & 28 & & 1.2 & \\
\hline
\end{tabular}

W- Fewer than 50 owners or less than 0.5 percent 


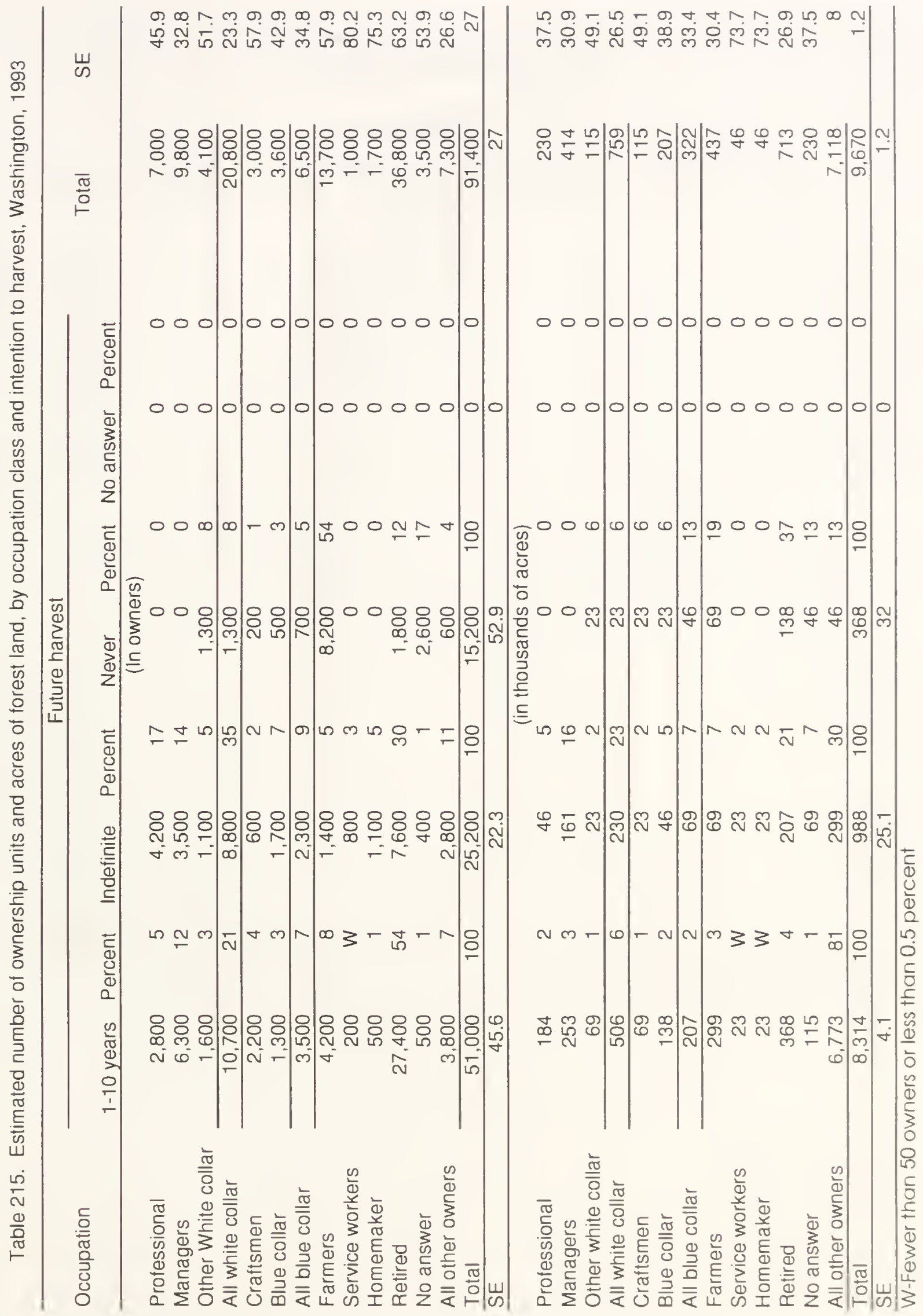


Table 216. Estimated number of ownership units and acres of forest land, by age class and past harvest experience, Washington, 1993

\begin{tabular}{|c|c|c|c|c|c|c|}
\hline \multirow[t]{2}{*}{ Age } & \multicolumn{4}{|c|}{ Harvest experience } & \multirow{2}{*}{ Total } & \multirow{2}{*}{ SE } \\
\hline & Harvested & Percent & Did not harvest & Percent & & \\
\hline \multicolumn{7}{|c|}{ (In owners) } \\
\hline Under 25 & 300 & W & 0 & 0 & 300 & 100 \\
\hline $25-34$ & 300 & W & 2,500 & 9 & 2,700 & 65.9 \\
\hline $35-44$ & 6,100 & 10 & 2,100 & 8 & 8,200 & 37.6 \\
\hline $45-54$ & 8,700 & 13 & 3,000 & 11 & 11,700 & 30.3 \\
\hline $55-64$ & 7,700 & 12 & 5,200 & 19 & 12,800 & 26.8 \\
\hline 65 or over & 34,500 & 54 & 12,500 & 46 & 47,000 & 52 \\
\hline No answer & 1,300 & 2 & 0 & 0 & 1,300 & 89.7 \\
\hline All other owners & 5,200 & 8 & 2,100 & 7 & 7,300 & 26.6 \\
\hline Total & 64,000 & 100 & 27,400 & 100 & 91,400 & 27 \\
\hline SE & 36.5 & & 33.3 & & 27 & \\
\hline \multicolumn{7}{|c|}{ (In thousands of acres) } \\
\hline Under 25 & 23 & W & 0 & 0 & 23 & 100 \\
\hline 25-34 & 23 & W & 46 & 8 & 69 & 61.2 \\
\hline $35-44$ & 230 & 3 & 115 & 19 & 345 & 32.7 \\
\hline $45-54$ & 345 & 4 & 92 & 15 & 437 & 30.4 \\
\hline $55-64$ & 437 & 5 & 138 & 23 & 575 & 28.3 \\
\hline 65 or over & 942 & 10 & 115 & 19 & 1,057 & 24.8 \\
\hline No answer & 46 & 1 & 0 & 0 & 46 & 73.7 \\
\hline All other owners & 7,026 & 77 & 92 & 15 & 7,118 & 8 \\
\hline Total & 9,072 & 100 & 598 & 100 & 9,670 & 1.2 \\
\hline SE & 2.2 & & 28 & & 1.2 & \\
\hline
\end{tabular}

W-Fewer than 50 owners of less than 0.5 percent 
Table 217. Estimated number of ownership units and acres of forest land, by date of aquisition and form of ownership, Washington, 1993

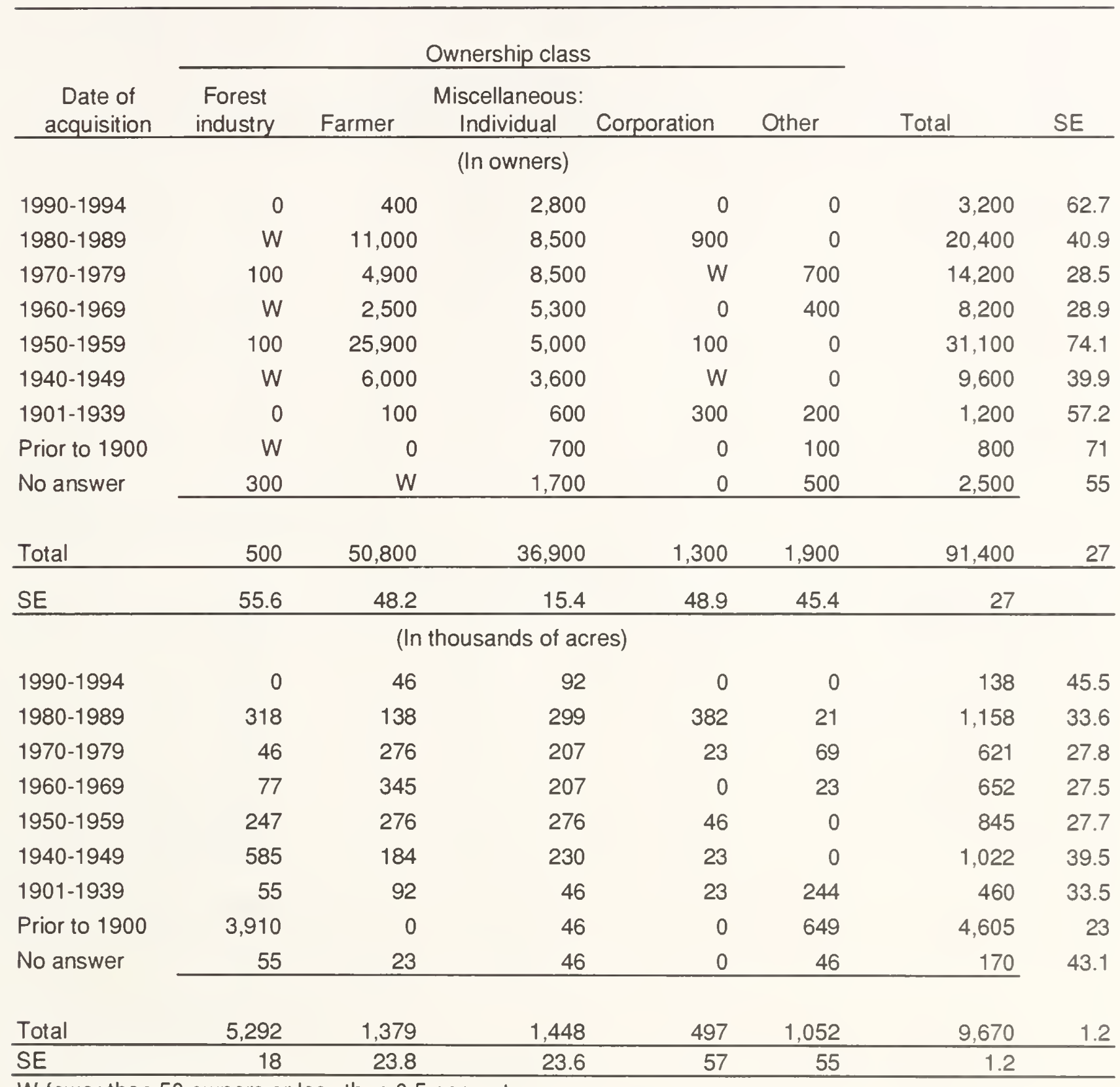

W-fewer than 50 owners or less than 0.5 percent 
Table 218. Estimated number of ownership units and acres of forest land, by distance from tracts, Washington, 1993

\begin{tabular}{|c|c|c|c|c|}
\hline \multirow[t]{3}{*}{ Distance } & \multicolumn{3}{|c|}{ Tracts } & \multirow{3}{*}{ Total } \\
\hline & \multirow[b]{2}{*}{1 tract } & \multicolumn{2}{|c|}{ More than one tract } & \\
\hline & & Nearest tract & Farthest tract & \\
\hline \multicolumn{5}{|c|}{ (In owners) } \\
\hline Less than 1 mile & 49,400 & 9,900 & 3,000 & \\
\hline 2-5 miles & 2,400 & 1,500 & 3,600 & \\
\hline 6-15 miles & 600 & 1,700 & 1,400 & \\
\hline 16-25 miles & 0 & 200 & 2,100 & \\
\hline 26-50 miles & 6,900 & 1,600 & 1,700 & \\
\hline $51-100$ miles & 1,400 & 1,700 & 2,800 & \\
\hline More than 100 miles & 8,200 & 4,200 & 6,500 & \\
\hline No answer & 1,200 & 100 & 100 & \\
\hline Total & 70,300 & 21,000 & 21,000 & 91,400 \\
\hline \multicolumn{5}{|c|}{ (In thousands of acres) } \\
\hline Less than 1 mile & 1,632 & 3,603 & 230 & \\
\hline 2-5 miles & 46 & 1,139 & 230 & \\
\hline $6-15$ miles & 46 & 754 & 204 & \\
\hline $16-25$ miles & 0 & 136 & 207 & \\
\hline $26-50$ miles & 253 & 866 & 436 & \\
\hline $51-100$ miles & 92 & 184 & 1,846 & \\
\hline More than 100 miles & 207 & 161 & 3,691 & \\
\hline No answer & 46 & 505 & 505 & \\
\hline Total & 2,322 & 7,348 & 7,348 & 9,670 \\
\hline
\end{tabular}


Table 219. Estimated number of ownership units and acres of forest land, by primary and secondary reason for owning forest land, Washington, 1993

\begin{tabular}{|c|c|c|c|c|}
\hline \multirow[t]{2}{*}{ Reason } & \multicolumn{2}{|c|}{ Primary reason } & \multicolumn{2}{|c|}{ Secondary reason } \\
\hline & Number & Percent & Number & Percent \\
\hline & \multicolumn{4}{|c|}{ (In owners) } \\
\hline Land investment & 14,300 & 16 & 2,400 & 3 \\
\hline Recreation & 1,900 & 2 & 8,900 & 10 \\
\hline Timber production & 3,500 & 4 & 3,700 & 4 \\
\hline Farm and domestic use & 6,500 & 7 & 3,300 & 4 \\
\hline Esthetic enjoyment & 5,200 & 6 & 5,900 & 6 \\
\hline Part of farm & 39,000 & 43 & 3,100 & 3 \\
\hline Part of residence & 5,600 & 6 & 25,200 & 28 \\
\hline Estate & 6,900 & 7 & 10,200 & 11 \\
\hline Other & 7,600 & 8 & 400 & W \\
\hline No secondary reason given & - & - & 27,300 & 30 \\
\hline No answer & 1,000 & 1 & 1,000 & 1 \\
\hline \multirow[t]{2}{*}{ Total } & 91,400 & 100 & 91,400 & 100 \\
\hline & \multicolumn{4}{|c|}{ (In thousands of acres) } \\
\hline Land investment & 667 & 7 & 1,599 & 16 \\
\hline Recreation & 161 & 2 & 253 & 3 \\
\hline Timber production & 5,502 & 57 & 454 & 5 \\
\hline Farm and domestic use & 368 & 4 & 322 & 3 \\
\hline Esthetic enjoyment & 207 & 2 & 343 & 4 \\
\hline Part of farm & 368 & 4 & 161 & 2 \\
\hline Part of residence & 207 & 2 & 273 & 3 \\
\hline Estate & 322 & 3 & 1,388 & 14 \\
\hline Other & 1,210 & 12 & 69 & 1 \\
\hline No secondary reason given & - & - & 4,149 & 43 \\
\hline No answer & 659 & 7 & 659 & 7 \\
\hline Total & 9,670 & 100 & 9,670 & 100 \\
\hline
\end{tabular}


Table 220. Estimated number of ownership units and acres of forest land, by primary benefit expected in the next 10 years and past harvest experience, Washington, 1993

\begin{tabular}{|c|c|c|c|c|c|c|}
\hline \multirow[t]{2}{*}{ Benefits expected } & \multicolumn{4}{|c|}{ Harvest Experience } & \multirow{2}{*}{ Total } & \multirow{2}{*}{ SE } \\
\hline & Harvested & Percent & Did not harvest & Percent & & \\
\hline \multicolumn{7}{|c|}{ (In owners) } \\
\hline Land value increase & 13,400 & 21 & 9,300 & 34 & 22,700 & 22.4 \\
\hline Recreation & 2,600 & 4 & 500 & 2 & 3,100 & 48.8 \\
\hline Income from timber & 5,500 & 9 & 100 & W & 5,600 & 21.8 \\
\hline Farm and domestic us $\epsilon$ & 4,000 & 6 & 1,100 & 4 & 5,200 & 42.5 \\
\hline Esthetic enjoyment & 10,700 & 17 & 11,800 & 43 & 22,500 & 37.3 \\
\hline Firewood & 23,400 & 37 & 0 & 0 & 23,400 & 98.3 \\
\hline Other & 4,100 & 6 & 2,200 & 8 & 6,300 & 51 \\
\hline No answer & 400 & 1 & 2,300 & 8 & 2,700 & 52.4 \\
\hline Total & 64,000 & 100 & 27,400 & 100 & 91,400 & 27 \\
\hline SE & 36.5 & & 33.3 & & 27 & \\
\hline \multicolumn{7}{|c|}{ (In thousands of acres) } \\
\hline Land value increase & 687 & 7 & 253 & 42 & 940 & 25.4 \\
\hline Recreation & 161 & 2 & 46 & 8 & 207 & 38.9 \\
\hline Income from timber & 5,686 & 63 & 23 & 4 & 5,709 & 16.5 \\
\hline Farm and domestic us $\epsilon$ & 299 & 3 & 23 & 4 & 322 & 33.4 \\
\hline Esthetic enjoyment & 506 & 5 & 138 & 23 & 644 & 27.5 \\
\hline Firewood & 46 & 1 & 0 & 0 & 46 & 73.7 \\
\hline Other & 1,029 & 11 & 46 & 8 & 1,075 & 68.2 \\
\hline No answer & 659 & 7 & 69 & 11 & 728 & 78.2 \\
\hline Total & 9,072 & 100 & 598 & 100 & 9.670 & 1.2 \\
\hline SE & 2.2 & & 28 & & 1.2 & \\
\hline
\end{tabular}

W-fewer than 50 owners or less than 0.5 percent 


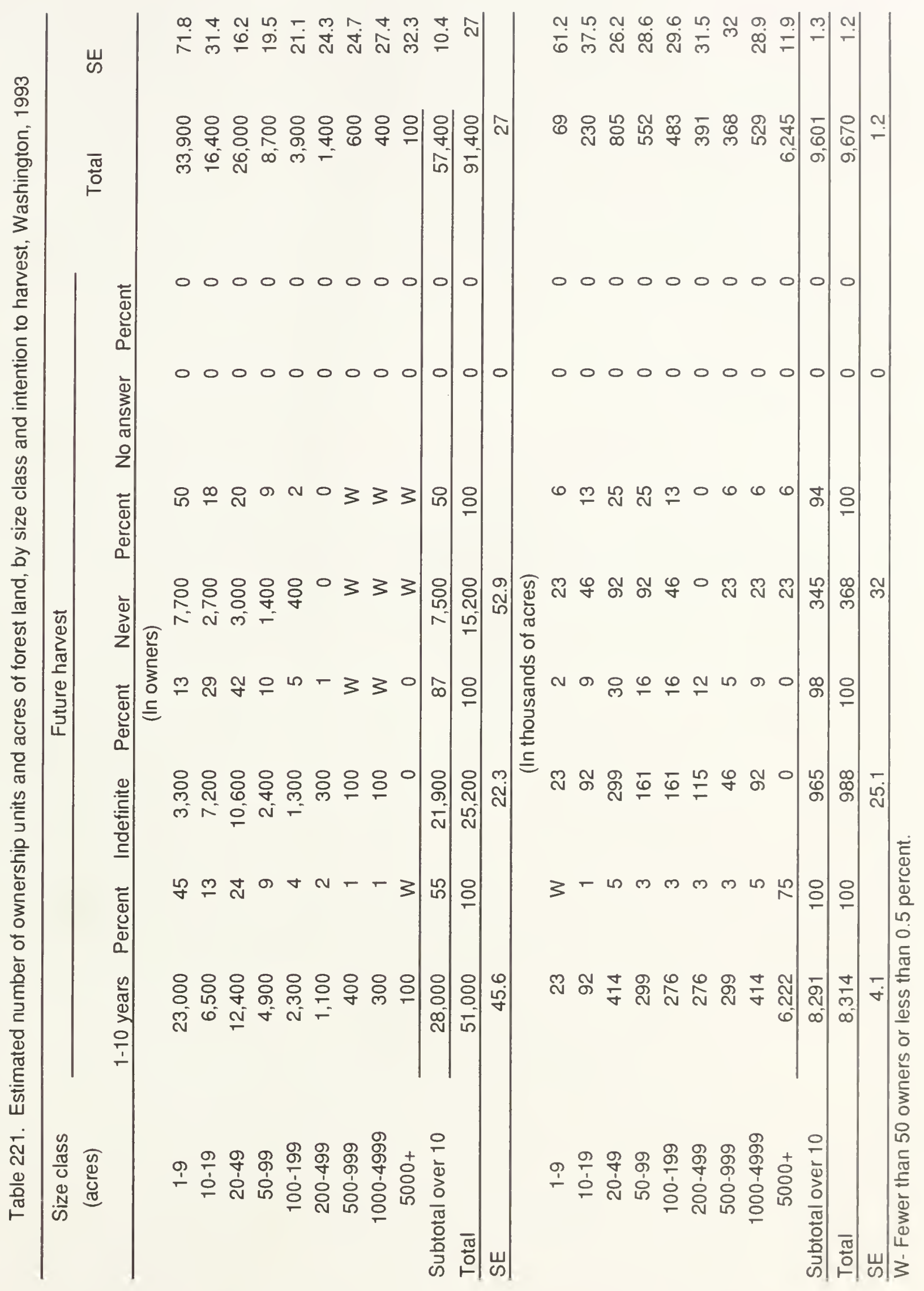



Birch, Thomas W. 1997. Private forest-land owners of the Western United States, 1994. Resour. Bull. NE-137. Radnor, PA: U.S. Department of Agriculture, Forest Service, Northeastern Forest Experiment Station. 249 p.

A statistical analytical report on a mail canvass of private forest-land owners in the Western United States. Landowner characteristics, attitudes, harvesting experience, tenure, and management planning are discussed.

Keywords: Forest-land ownership, timber harvesting 
Headquarters of the Northeastern Forest Experiment Station is in Radnor, Pennsylvania. Field laboratories are maintained at:

Amherst, Massachusetts, in cooperation with the University of Massachusetts

Bradley, Maine, in cooperation with the University of Maine

Burlington, Vermont, in cooperation with the University of Vermont

Delaware, Ohio

Durham, New Hampshire, in cooperation with the University of New Hampshire Hamden, Connecticut, in cooperation with Yale University

Morgantown, West Virginia, in cooperation with West Virginia University

Parsons, West Virginia

Princeton, West Virginia

Syracuse, New York, in cooperation with the State University of New York, College of Environmental Sciences and Forestry at Syracuse University

Warren, Pennsylvania

The United States Department of Agriculture (USDA) prohibits discrimination in its programs on the basis of race, color, national origin, sex, religion, age, disability, political beliefs, and marital or familial status. (Not all prohibited bases apply to all programs.) Persons with disabilities who require alternative means of communication of program information (braille, large print, audiotape, etc.) should contact the USDA Office of Communications at (202)720-2791.

To file a complaint, write the Secretary of Agriculture, U.S. Department of Agriculture, Washington, DC 20250, or call 1-(800)245-6340 (voice) or (202)720-1127 (TDD). USDA is an equal opportunity employer.

"Caring for the Land and Serving People Through Research" 